\title{
KAROTINTERMELŐ JÁROMSPÓRÁS GOMBÁK GENETIKAI MÓDOSÍTÁSÁNAK LEHETŐSÉGEI
}

DOKTORI ÉRTEKEZÉS

CSERNETICS ÁRPÁD

TÉMAVEZETŐ:

DR. PAPP TAMÁS

EGYETEMI DOCENS

BIOLÓGIA DOKTORI ISKOLA

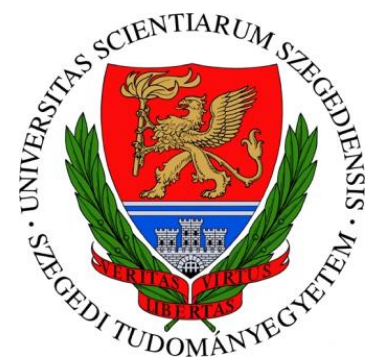

SZEGEDI TUdOMÁNYEGYETEM

TERMÉSZETTUDOMÁNYI ÉS INFORMATIKAI KAR

MIKROBIOLÓGIAI TANSZÉK 


\section{TARTALOMJEGYZÉK}

1. RÖVIDÍTÉSEK JEGYZÉKE 4

2. BEVEZETÉS

3. IRODALMI ÁTTEKINTÉS 9

3.1. A járomspórás gombák általános jellemzése 9

3.2. A karotinoidok szerepe és ipari jelentősége $\quad 10$

3.3. A karotinoidok szerkezete és bioszintézisének főbb lépései 12

3.4. A karotinoidok bioszintézisének genetikai és molekuláris alapjai $\begin{array}{ll}\text { gombákban } & 18\end{array}$

3.5. Járomspórás gombák a karotin-bioszintézis kutatásában 22

3.6. Járomspórás gombák genetikai transzformációja 23

4. CÉLKITŰZÉSEK 30

5. ANYAGOK ÉS MÓDSZEREK 31

5.1. A kísérletek során alkalmazott törzsek 31

5.2. Alkalmazott táptalajok, tápoldatok és tenyésztési körülmények 31

5.3. Alkalmazott oldatok, pufferek és reagensek 32

5.4. A kísérletek során alkalmazott primerek és DNS próbák 35

5.5. A kísérletek során felhasznált expressziós vektorok 37

5.6. Vizsgálati módszerek 38

5.6.1. DNS tisztítása Mucor circinelloides-ből 38

5.6.2. RNS tisztítása M. circinelloides-ből 39

5.6.3. DNS/RNS gélelektroforézis 39

5.6.4. DNS izolálása agaróz gélből $\quad 40$

5.6.5. Alkalmazott PCR technikák és reakciókörülmények 40

5.6.6. Génklónozás során alkalmazott módszerek, plazmid konstrukciók létrehozása 43

5.6.7. Szekvenciák meghatározása és elemzése 44

5.6.8. Baktérium telep/DNS blottolás és hibridizálás 45

5.6.9. Northern hibridizálás 46

5.6.10. Kompetens Escherichia coli sejtek készítése 46

5.6.11. E. coli sejtek transzformációja 46

5.6.12. Kompetens Agrobacterium tumefaciens sejtek készítése 47

5.6.13. A. tumefaciens sejtek transzformációja 47 
5.6.14. Protoplasztképzés $M$. circinelloides-ből 48

5.6.15. M. circinelloides protoplasztok PEG-mediált transzformációja 48

5.6.16. A. tumefaciens-közvetített transzformáció (ATMT) 49

5.6.17. Monosporangiális telepek izolálása és a mitótikus stabilitás vizsgálata 50

5.6.18. Karotinoid kivonás $\quad 50$

5.6.19. A karotinoid minták elemzése 51

6. EREDMÉNYEK ÉS ÉRTÉKELÉSÜK

6.1. Xantofillok termeltetése Mucor circinelloides-ben 52

6.2. $\beta$-karotin-, valamint xantofillok termeltetésének fokozása

M. circinelloides-ben $\quad 57$

6.2.1. Az ipi gén klónozása és jellemzése 57

6.2.2. Cirkuláris transzformáló vektorok építése 60

6.2.3. A cirkuláris plazmidokkal nyert transzformánsok elemzése 63

6.3. A crtW gén integrációja a Mucor genomba 76

6.3.1. Expressziós vektorok építése és transzformációs kísérletek 77

6.3.2. Az integratív transzformánsok elemzése $\quad 79$

6.4. A $c r t W$ és a carRP gének fúziója, valamit a carRP gén elrontása 96

6.4.1. Expressziós vektorok építése és transzformációs kísérletek 96

6.4.2. Cirkuláris plazmidokkal nyert transzformánsok elemzése 97

7. ÖSSZEFOGLALÁs 99

8. SUMMARY 103

9. IRODALOMJEGYZÉK 107

10. KöSZÖNETNYILVÁNÍTÁS 122

11. MELLÉKLETEK 123 


\section{RöVIDÍTÉSEK JEGYZÉKE}

\begin{tabular}{|c|c|}
\hline APE & al-3 proximal element \\
\hline AS & acetosziringon \\
\hline ATCC & American Type Culture Collection, USA \\
\hline ATMT & Agrobacterium tumefaciens-közvetített transzformáció \\
\hline BLAST & Basic Local Alignment Search Tool \\
\hline CBS & Centraalbureau voor Schimmelcultures, The Netherlands \\
\hline DEPC & dietil-pirokarbonát \\
\hline DMSO & dimetil-szulfoxid \\
\hline EDTA & etilén-diamin-tetraecetsav \\
\hline EMBL & European Molecular Biology Laboratory \\
\hline FPP & farnezil-pirofoszfát \\
\hline GGPP & geranilgeranil-pirofoszfát \\
\hline GPP & geranil-pirofoszfát \\
\hline HMG-KoA & 3-hidroxi-3-metilglutaril-koenzim A \\
\hline HPLC & High Performance Liquid Chromatography \\
\hline & (nagyhatékonyságú folyadékkromatográfia) \\
\hline IPP & izopentenil-pirofoszfát \\
\hline IPTG & izopropil- $\beta$-D-tiogalaktopiranozid \\
\hline ITS & Internal Transcribed Spacer (belső átíródó szekvencia) \\
\hline LB & Left Border (bal oldali T-DNS határoló régió) \\
\hline LB & Luria-Broth (Luria-féle tápleves) \\
\hline MBIC & Marine Biotechnology Institute Culture Collection, Japan \\
\hline MEA & Malt Extract Agar (malátás táptalaj) \\
\hline MES & 2-N-morfolin-etánszulfonsav \\
\hline MOPS & 3-N-morfolin-propánszulfonsav \\
\hline MUFS & $\begin{array}{l}\text { Department of Microbiology and Biochemistry, The } \\
\text { University of the Orange Free State, South Africa }\end{array}$ \\
\hline NCBI & National Center for Biotechnology Information \\
\hline NRRL & Agricultural Research Service Culture Collection, USA \\
\hline OD & optikai denzitás \\
\hline OMP & orotidin-5'-monofoszfát \\
\hline PBS & foszfát-pufferelt sóoldat \\
\hline
\end{tabular}




$\begin{array}{ll}\text { PCI } & \text { fenol - kloroform - izoamilalkohol } \\ \text { PCR } & \text { Polimerase Chain Reaction (polimeráz láncreakció) } \\ \text { PEG } & \text { polietilén-glikol } \\ \text { PMC } & \text { PEG - szorbitol - MOPS - kálcium-klorid } \\ \text { prenylPP } & \text { E-prenil-difoszfát } \\ \text { RB } & \text { Right Border (jobb oldali T-DNS határoló régió) } \\ \text { rDNS } & \text { riboszómális DNS } \\ \text { REMI } & \text { Restriction Enzyme-Mediated Integration (restrikciós enzim- } \\ & \text { közvetített integráció) } \\ \text { RNáz } & \text { ribonukleáz } \\ \text { ROS } & \text { Reactive Oxygen Species (reaktív oxigénféleség) } \\ \text { RPM } & \text { Revolutions Per Minute (percenkénti fordulatszám) } \\ \text { SDS } & \text { nátrium-lauril-szulfát } \\ \text { SMC } & \text { szorbitol - MOPS - kálcium-klorid } \\ \text { SOC } & \text { Super Optimal broth with Catabolite Repression } \\ \text { SSC } & \text { nátrium-klorid - nátrium-citrát } \\ \text { SZMC } & \text { Szeged Microbial Collection, University of Szeged, Hungary } \\ \text { TAE } & \text { Tris - ecetsav - dinátrium-EDTA } \\ \text { TLC } & \text { Thin Layer Chromatography (vékonyréteg kromatográfia) } \\ \text { TRIS } & \text { trisz-(hidroxi-metil)-amino-metán } \\ \text { X-Gal } & \text { Y-bromo-4-kloro-3-indolil- } \beta \text {-D-galaktopiranozid } \\ \text { YPG } & \text { Yeast extract - Pepton - Glucose medium (élesztő kivonat - } \\ \text { YNB } & \text { TRL CN }\end{array}$

A doktori értekezésben előforduló fontosabb gének jelölései és az általuk kódolt enzimek:

Paracoccus sp. N81106 törzs (korábbi elnevezése Agrobacterium aurantiacum):

$\begin{array}{ll}c r t B & \text { fitoén szintáz } \\ c r t I & \text { fitoén deszaturáz } \\ c r t Y & \text { likopin cikláz } \\ c r t W & \beta \text {-karotin ketoláz }\end{array}$




$\begin{array}{ll}\text { crtZ } & \beta \text {-karotin hidroxiláz } \\ \text { Mucor circinelloides: } & \\ \text { gpd } & \text { glicerinaldehid-3-foszfát dehidrogenáz } \\ \text { ipi } & \text { IPP izomeráz } \\ \text { isoA } & \text { FPP szintáz } \\ \text { carG } & \text { GGPP szintáz } \\ \text { carRP } & \text { fitoén szintáz/likopin cikláz } \\ \text { leuA } & \alpha \text {-izopropilmalát izomeráz } \\ \text { pyrG } & \text { orotidin-5'-monofoszfát dekarboxiláz }\end{array}$




\section{BEVEZETÉS}

A karotinoidok az egyik leggyakrabban elöforduló és legváltozatosabb természetes pigmentcsoport. Nagy mennyiségben használják az élelmiszer-, a kozmetikai- és a gyógyszeriparban, valamint az állattenyésztés során. Ismert antioxidánsok, kimutatták daganatos megbetegedésekkel szembeni megelőző és az immunrendszert erősítő hatásukat is. Ma a felhasznált karotinoidok nagy részét kémiai szintézissel állítják elő, azonban egyre nagyobb igény mutatkozik a természetes forrásból származó, ezen belül is a mikroorganizmusokkal előállított vegyületek iránt. A mikrobiológiai eredetü karotinoidok felhasználásának egyik legfőbb akadálya jelenleg a termelékenység alacsony szintje.

A járomspórás gombák, különösen a Phycomyces, a Blakeslea és a Mucor nemzetségek tagjai régóta használt modellorganizmusai a karotin-bioszintézis biokémiai és genetikai tanulmányozásának. A karotin-bioszintézisben résztvevő gének funkcionális vizsgálatához és a biotechnológiai szempontból jelentős törzsek módosításához nélkülözhetetlenek a stabil transzformánsokat eredményező transzformációs rendszerek. Ugyanakkor viszonylag kevés az olyan járomspórás gombafajok száma, melyekkel sikeres transzformációt hajtottak végre, továbbá korlátozottak az ismereteink a bejuttatott DNS sorsát illetően is, mindezek pedig megnehezítik a hatékony törzsnemesítést.

Munkánk során célul tủztük ki, hogy rekombináns technikákat alkalmazva a Mucor circinelloides karotin bioszintézisét úgy módosítsuk, hogy egyrészt növeljük a gomba $\beta$ karotin termelését, másrészt lehetővé tegyük értékes oxigéntartalmú $\beta$-karotinszármazékok, elsősorban kantaxantin és asztaxantin termelődését. Ezért az asztaxantintermelő Paracoccus sp. N81106 törzs $\beta$-karotin - asztaxantin konverzióért felelős génjeit hordozó expressziós vektorokat szerkesztettünk és ezekkel transzformáltuk a $M$. circinelloides MS12 törzset. Vizsgálataink másik területe karotinoid-túltermelö törzsek elöállítása volt. Ennek érdekében a nem karotin-specifikus izoprén bioszintézis út genetikai módosítását célzó kísérleteket végeztünk. Ez bizonyos gének túlmüködtetését jelentette a géndózishatás alapján.

Ismert, hogy a járomspórás gombákba bejuttatott cirkuláris DNS autonóm replikálódó elemként marad fenn, anélkül, hogy beépülne a gazda genomjába. Az integráció kikényszeríthető, ha olyan lineáris fragmentumokkal végezzük a transzformációt, melyek a kettős rekombinációt irányító homológ szakaszokat hordoznak. Egy másik, viszonylag újonnan alkalmazott módszer, az Agrobacterium tumefaciensközvetített transzformáció, amely szintén integrációt eredményez. Célul tüztük ki 
módosított karotinoid-termelő $M$. circinelloides törzsek előállítását különböző transzformációs rendszerek alkalmazásával. Vizsgálni kívántuk a transzformánsok karotinoid termelését, valamint a bejuttatott transzformáló DNS sorsát mind az autonóm replikálódó plazmidokat hordozó, mind az integratív transzformánsok esetében. 


\section{IRODALMI ÁTTEKINTÉS}

\subsection{A járomspórás gombák általános jellemzése}

A járomspórás gombák (Zygomycota) az egyik legváltozatosabb és legkevésbé tanulmányozott gombacsoport, melyet a korábbi feltételezésekkel ellentétben ma már polifiletikusnak vélnek (Barr 1992, Benny és mtsi. 2001). Alapvető jellegeik a cönocitikus micélium, a kitin és kitozán tartalmú sejtfal és a sporangiumokban ivartalanul képződő sporangiospórák. Az 1. ábrán egy járomspórás gomba cönocitikus micéliuma és sporangiumai láthatók. A csoport sokszínűségét mutatja, hogy a felsorolt jellegektől meröben eltérő fajokat is szép számban találunk. Ivaros szaporodásmódjuk eredménye a zigospóra (járomspóra), melyről a csoport a nevét is kapta.
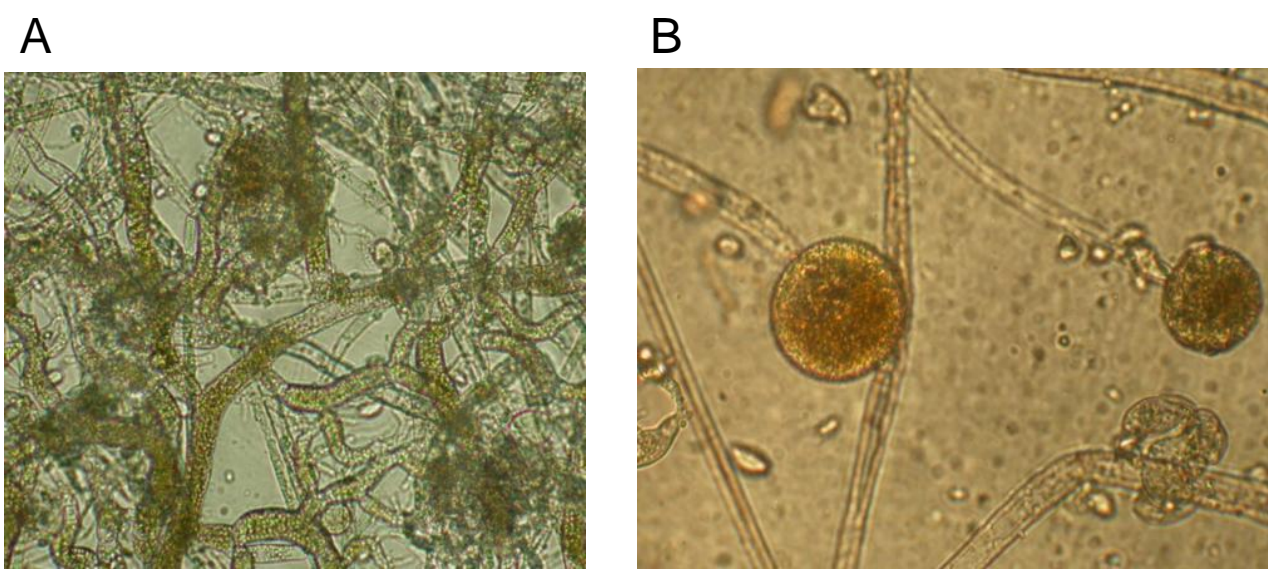

1. ábra. A M. circinelloides cönocitikus micéliuma (A) és sporangiuma (B).

A hagyományos felosztás a járomspórás gombák két osztályát különíti el. Ezek a Zygomycetes és a Trichomycetes. Megjegyzendő, hogy a legújabb molekuláris vizsgálatok hatására a járomspórás gombák rendszertana jelentős átalakuláson megy át; az új kutatási eredmények értelmében az eddig azonosított közel 900 faj többségét, az általunk vizsgált Mucor circinelloides modellorganizmussal együtt a Mucoromycotina altörzs Mucorales rendjébe sorolják (White és mtsi. 2006, James és mtsi. 2006). Olyan elméleti és gyakorlati szempontból jelentős nemzetségek sorolhatók ide, mint az Absidia, Gilbertella, Mucor, Phycomyces, Rhizopus vagy Rhizomucor. Tagjai föként szaprofiták, talajban, valamint bomló növényi és állati szerves maradványokon fordulnak elő. A járomspórás gombák között találunk rovarpatogéneket, állati és mikoparazitákat, endo- és ektomikorrhiza alkotókat, valamint obligát szimbiontákat is (Benny és mtsi. 2001, Benny 2001).

A járomspórás gombák egyes képviselői nagy gyakorlati jelentőséggel bírnak az ipari és a biotechnológiai alkalmazások területén. Számos törzset használnak az élelmiszer- 
és gyógyszeriparban, többek között extracelluláris enzimek, pl. lipáz, renin, proteázok (Outrupp és Boyce 1990, Godtfredsen 1990), többszörösen telítetlen zsírsavak (Carter 1988, Ward 1995, Yamada és mtsi. 1992) és karotinoidok (Iturriaga 2000, 2001, 2005, Mehta és mtsi. 2003, Dufossé 2006) termeltetésére, valamint szteroidvázas vegyületek sztereospecifikus hidroxilálására (Madyastha és Srivatsan 1989). Több Mucor, Rhizopus valamint Actinomucor faj megtalálható speciális fermentációval készülő távol-keleti étel (pl. koji, ragi) starter kultúráiban (Han és mtsi. 2001). Élelmiszeripari (Devoyod 1988) és mezőgazdasági (Michailides és Ogawa 1985) termények raktári kártevőiként komoly károkat okoz számos, a Mucorales rendbe tartozó faj (Csernetics és mtsi. 2005). Több fajnak klinikai jelentősége is van: opportunista humánpatogénként legyengült immunrendszerü betegekben súlyos fertőzéseket (zigomikózisokat) okozhatnak (Ribes 2000, Walsh és mtsi. 2004, Chayakulkeeree és mtsi. 2006, Papp és mtsi. 2008). Számos, a biológiai kutatások szempontjából jelentős nemzetség (Absidia, Blakeslea, Gilbertella, Micromucor, Mortierella, Mucor, Phycomyces, Rhizomucor, Rhizopus) sorolható a járomspórás gombák közé. Az egyik legtöbbet kutatott modellorganizmus a Mucor circinelloides, ahol a vizsgálatok a gomba dimorf karakterére, a morfogenezis fiziológiai és biokémiai alapjaira (Orlowsky 1991, Ruiz-Herrera 1993), a szexuális folyamatok vizsgálatára és a szexferomonok, így a trispórsav szerepére (Gooday 1994, Orlowsky 1994), valamint a másodlagos metabolitok, elsősorban a karotinoidok bioszintézisére (Iturriaga és mtsi. 1992, 2000, 2001, 2005, Navarro és mtsi. 2000, Papp és mtsi. 2006, Velayos és mtsi. 1997, 2000a, 2000b) irányulnak.

\subsection{A karotinoidok szerepe és ipari jelentősége}

A karotinoidok az egyik leggyakrabban elöforduló és legváltozatosabb természetes pigmentcsoport. Megtalálhatók a fotoszintetizáló szervezetekben (növényekben, algákban és fotoszintetizáló baktériumokban), ahol részt vesznek a fotoszintézis folyamatában mint másodlagos fénygyüjtő molekulák (Mathis és Schenk 1982). Szerepet játszanak a fototropizmus és a fototaxis folyamatában (Goodwin 1980). Növényekben virágok és termések festékanyagai, fitohormonok prekurzorai (pl. abszcizinsav) lehetnek. A fény által okozott stresszel szembeni védekezésben (Edge és mtsi. 1997), illetve a szabadgyökök és a reaktív oxigénféleségek (ROS) elleni fotooxidatív védelemben (Sandmann és Misawa 2002) is fontos szerepük van. Heterotróf szervezetekben is nagy jelentőséggel bírnak: körülbelül hatvan olyan karotinszármazékot ismerünk, mely az A vitamin elöanyaga lehet emlösökben (pl. $\alpha$-karotin, $\beta$-karotin, $\beta$-kriptoxantin, zeaxantin; Simpson 1983), ezenkívül részt vesznek a sejtdifferenciálódás (gap-junction kommunikációs mechanizmus 
indukciója), a látás (a retinál és a retinolsav előanyagaiként; Olson 1964) és a táplálkozás folyamatában (Paiva és Russel 1999).

A karotinoidokat elsősorban az élelmiszer-, a kozmetikai- és a gyógyszeriparban alkalmazzák. Takarmányadalékként nagy mennyiségben használják az állattenyésztésben is, pl. egyes halféléknél (lazac, pisztráng) a hús színének és minőségének javítására, valamint szárnyasoknál a bőr és a tojás színének élénkítésére. Az élelmiszeriparban táplálék-kiegészítőként és ételszínezékként alkalmazzák (pl. vajban, margarinban, üdítő italokban), egyrészt az antioxidáns és A provitamin tulajdonságuk miatt, másfelől pedig azért, mert az ételek természetes karotintartalma az előállítás, a tárolás és a szállítás során megváltozik, mivel ezek a vegyületek fény és oxigén jelenlétében gyorsan degradálódnak.

Régóta ismert a karotinszármazékok antioxidáns, azaz szabadgyök hatástalanító tulajdonsága (Burton 1989, Paiva és Russel 1999, Naguib 2000). Az emberi szervezetben a karotinoidok megtalálhatók a bőr epidermális rétegében. Zsíroldékonyak, ezért kis sürüségü lipoproteinekkel (LDL) szemben mutatnak erős affinitást. Elsődleges antioxidáns hatásuk a legjelentősebb, ami a szinglet oxigén, a triplet gerjesztett állapot, valamint a peroxidgyökök közömbösítésében nyilvánul meg (Cantrell és mtsi. 2003, Britton és mtsi. 2008). Ez meghatározza a táplálkozásban betöltött szerepüket is. A szabadgyökök károsító hatása sok betegségben kimutatható: nagy szerepet játszanak a sejtek öregedési folyamataiban, a koszorúér-elmeszesedés, a szívinfarktus, bizonyos májbetegségek, rákos megbetegedések és bőrgyógyászati elváltozások kialakulásában. Fontos megemlíteni, hogy a szabadgyökök a spermiumok DNS-ét károsító hatásuk révén örökletes betegségek okozói is lehetnek. Érthető tehát az antioxidánsok fontos szerepe e betegségek megelőzésében és gyógyításában (Halliwell és Gutteridge 1999, Klotz és mtsi. 2000). Ennek megfelelően igazolták a karotinoidok szív és érrendszeri-, valamint daganatos betegségeket megelőző és immunrendszert erősítő hatását (Jyonouchi és mtsi. 1994, 1996, Okai és Higashi-Okai 1996, Hughes 1999). Így a nemrégiben végzett állati és emberi vizsgálatok kimutatták, hogy a $\beta$-karotin (akárcsak az asztaxantin, kantaxantin és a likopin) jelentős mértékben csökkenti a száj-, a prosztata-, a mell- és egyéb rákos elváltozások (Matthews-Roth és Krinsky 1987, Mayne és Parker 1989, Chew 1993, Vainio és Rautalahti 1998, Chew és mtsi. 1999, Nishino és mtsi. 2002) valamint az Alzheimer-kór kialakulásának esélyét (Zaman és mtsi. 1992). A kantaxantinról kimutatták, hogy apoptózist indukál az emberi rákos sejtvonalakban (Palozza 1998, Palozza és mtsi. 1998). Egyes xantofillok (pl. zeaxantin, lutein) jelentőséggel bírnak az időskori makuláris degeneráció megelőzésében (Bhosale és Bernstein 2005). 
A karotinoidok nagy részéhez táplálék útján jutunk, azonban ételeink számos, a táplálkozás szempontjából fontos karotinoidból keveset tartalmaznak (ilyen pl. a zeaxantin is, amely a luteinnel együtt alapvető alkotója a szem pigmentjeinek) és ezek egy részéhez táplálék-kiegészítőként sem lehet hozzájutni.

Napjainkban az iparban felhasznált karotinoidok többségét kémiai szintézissel állítják elö, csak kis hányadát vonják ki növényekből (Johnson és Schroeder 1995, Bhosale 2004). A jelenlegi mesterséges karotinszármazékok azonban csupán néhány vegyületre korlátozódnak. Emellett a mesterségesen előállított karotinoidok csupán egy, míg a természetes forrásból származók több vegyületből állnak. Erre jó példa a szintetikus $\beta$ karotin, ami csak all-transz izomerekből áll, szemben a biológiai eredetű $\beta$-karotinnal, amely all-transz izomerek mellett tartalmaz cisz-izomereket (pl. 9-cisz izomer), sőt sok esetben, kis mennyiségben prekurzorokat is. A legnagyobb mennyiségben előállított karotinoid a $\beta$-karotin, de jelentős mértékü a likopin és az asztaxantin előállítás is. A jelenleg kereskedelmi forgalomban lévő asztaxantint, ami a $\beta$-karotin keto-származéka, szinte kizárólag kémiai szintézissel állítják elő, az ára többszöröse a $\beta$-karotinénak. Az asztaxantin és a kantaxantin kiváló antioxidánsok, a $\beta$-karotinnál is erősebb antioxidáns hatással rendelkeznek (Palozza és Krinsky 1992), ezért jelentős szerepük lehet egyes daganatos elváltozások és az érszükület megelőzésében. A további vizsgálatokhoz nagy tisztaságú karotinoidokra van szükség, ezek nagy mennyiségben történő előállítása azonban nagyon költséges. Egyre növekvő igény mutatkozik a szintetikus adalékanyagok természetes eredetű anyagokkal történő felváltására, azon belül is kiemelt jelentősége van a mikroorganizmusokkal történő termeltetésnek. Több, az iparban karotinoid termelésre már alkalmazott törzs mellett számos kísérlet folyik új, túltermelő mutáns törzsek előállítására, melyek közül a legjelentősebbeket az 1. táblázat foglalja össze. Ma a biológiai eredetü karotinoidok termeltetésének fő nehézsége, hogy a termelés mértéke elmarad az ipari követelményektől.

\subsection{A karotinoidok szerkezete és bioszintézisének fôbb lépései}

A karotinoidok zsíroldékony, 3-15 konjugált kettős kötést tartalmazó, általában 40 szénatomból álló, izoprénvázas, ciklikus vagy aciklikus vegyületek (2. ábra). A természetben általában a stabilabb all-transz izomerük fordul elö, de a cisz izomer is megtalálható (Rodriguez-Amaya 2001). A szénhidrogén jellegü karotinoidokat nevezzük karotinoknak, míg a xantofillok oxigéntartalmú szubsztituált karotinszármazékok, melyek hidroxi-, keto-, metoxi-, epoxi- vagy karboxil csoportot tartalmaznak. Színük az izomer állapotuktól és a konjugált kettős kötések számától függően a sárgától egészen a pirosig 
terjedhet. A hétnél kevesebb konjugált kettős kötést tartalmazó vegyületek színtelenek, mivel képesek a látható fényt abszorbeálni (Britton 1983, Rodriguez-Amaya 2001).

\begin{tabular}{|c|c|c|c|}
\hline Pigment & Mikroorganizmus & Állapot & Hivatkozások \\
\hline \multirow{4}{*}{ asztaxantin } & $\begin{array}{c}\text { Xanthophyllomyces dendrorhous } \\
\text { (anamorfja Phaffia rhodozyma) }\end{array}$ & $\mathrm{F}$ & $\begin{array}{l}\text { Ramirez és mtsi. 2000, Vazquez és mtsi. 1998, } \\
\text { Verdoes és mtsi. 1999a, 1999b, 2003, Flores-Cotera } \\
\text { és Sanchez 2001, Visser és mtsi. 2003, } 2005\end{array}$ \\
\hline & $\begin{array}{l}\text { Paracoccus sp. } \text { N81106 törzse } \\
\text { (Agrobacterium aurantiacum) }\end{array}$ & K & Yokoyama és mtsi. 1994 \\
\hline & Paracoccus carotinifaciens & $\mathrm{K}$ & Tsubokura és mtsi. 1999 \\
\hline & Hematococcus pluvialis & I & $\begin{array}{l}\text { Boussiba 2000, Guerin és mtsi. 2003, Steinbrenner és } \\
\text { Linden 2003, Jin és mtsi. 2006, Vidhyavathi és mtsi. } \\
2008\end{array}$ \\
\hline kantaxantin & Bradyrhizobium sp. & $\mathrm{K}$ & Hannibal és mtsi. 2000 \\
\hline \multirow{2}{*}{ likopin } & Blakeslea trispora & $\mathrm{F}$ & Vitatene Kft. 2003 \\
\hline & Fusarium sporotrichioides & $\mathrm{K}$ & Jones és mtsi. 2004 \\
\hline riboflavin & Ashbya gossypi & $\mathrm{I}$ & Santos és mtsi. 2005 \\
\hline \multirow{2}{*}{ zeaxantin } & Flavobacterium sp. & $\mathrm{F}$ & Shepherd és mtsi. 1976 \\
\hline & Paracoccus zeaxanthinifaciens & $\mathrm{K}$ & Hümbelin és mtsi. 2002 \\
\hline \multirow{6}{*}{$\beta$-karotin } & Blakeslea trispora & I & $\begin{array}{l}\text { Ciegler 1965, Ninet és Renaut 1979, Lampila és mtsi. } \\
\text { 1985, Mehta és Cerdá-Olmedo 1995, Mehta és mtsi. } \\
\text { 2003, Rodríguez-Sáiz és mtsi. } 2004\end{array}$ \\
\hline & Fusarium sporotrichioides & $\mathrm{K}$ & Jones és mtsi. 2004 \\
\hline & Mucor circinelloides & $\mathrm{F}$ & Iturriaga és mtsi. 2000, 2001, 2005 \\
\hline & Neurospora crassa & $\mathrm{K}$ & Hausmann és Sandmann 2000 \\
\hline & Phycomyces blakesleeanus & K & $\begin{array}{l}\text { Cerdá-Olmedo 2001, Kuzina és Cerdá-Olmedo 2007, } \\
\text { Almeida és Cerdá-Olmedo } 2008\end{array}$ \\
\hline & Dunaliella sp. & $\mathrm{I}$ & Finney és mtsi. 1994, Mokady és mtsi. 1989 \\
\hline lutein & Dunaliella sp. & $\mathrm{I}$ & Mokady és mtsi. 1989 \\
\hline
\end{tabular}

1. táblázat. Néhány, az ipar által is hasznosított pigment és az azokat termelő, már alkalmazott vagy épp kutatás alatt álló mikroorganizmusok (Dufossé és mtsi. 2005, Dufossé 2006 alapján). A hivatkozások között csak néhány kiragadott példa látható a teljesség igénye nélkül.

I - ipari alkalmazás; F - fejlesztési szakasz; K - kísérleti szakasz.
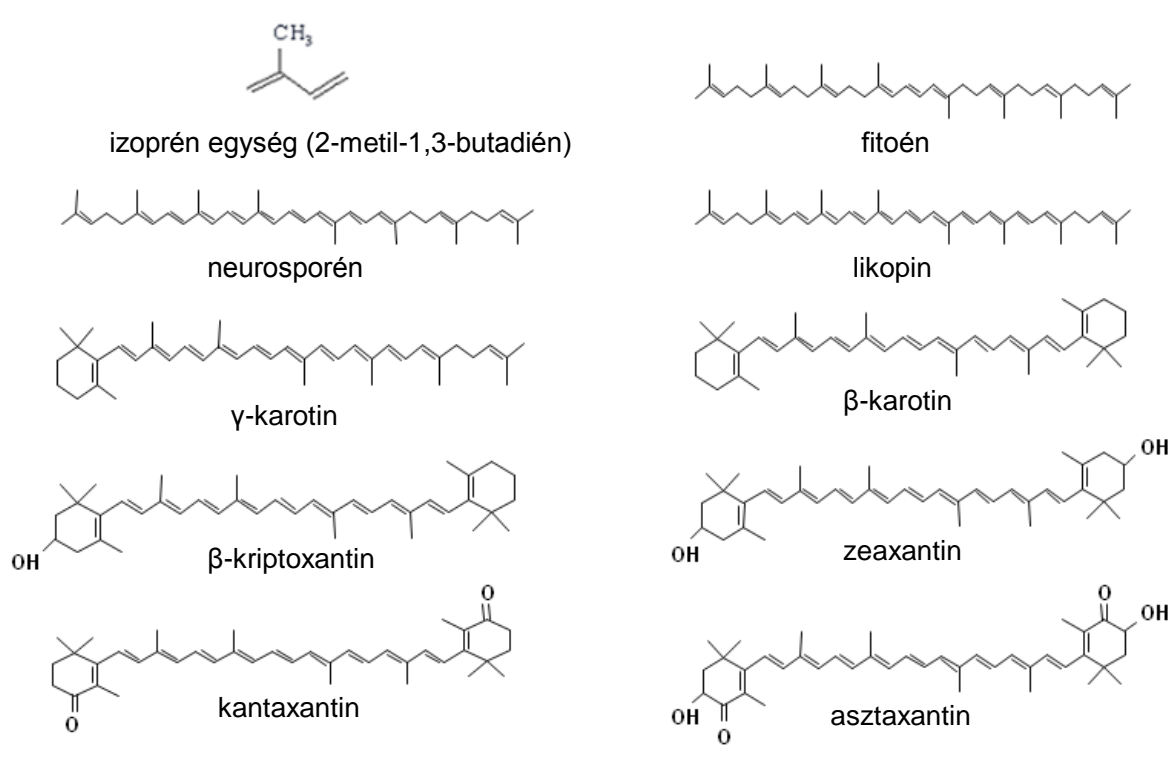

2. ábra. A karotinoidokat alkotó izoprén alegység, valamint néhány aciklikus és ciklikus karotinoid szerkezeti képlete. 
Antioxidáns hatásuk szerkezetüktől (kettős kötések száma, a funkciós csoportok elhelyezkedése és száma), valamint a membránban elfoglalt pozíciójuktól és orientációjuktól függ. Ismert, hogy a konjugált kettős kötések számának növelése egyben növeli az oxigéngyök hatástalanító képességüket (Cantrell és mtsi. 2003), így pl. a likopin erősebb antioxidáns, mint a $\beta$-karotin.

A karotinoidok bioszintetikus reakcióútjának (Armstrong és Hearst 1996, Britton 1998, Cunningham és Gantt 1998) első fele megegyezik más izoprén-származékokéval (pl. szterolok, szteroidok, terpének, kinonok). Archeákban, gombákban, állatokban és növényekben (de nem a növényi plasztiszokban) ezen első szakasz az ún. mevalonsav út. Kulcs intermedierje a 3-hidroxi-3-metilglutaril-koenzim A (HMG-KoA), amely 3 acetilkoenzim A kondenzációjával jön létre. A HMG-KoA mevalonsavvá alakulását a HMGKoA reduktáz katalizálja. A mevalonsav több reakciólépés után izopentenil-pirofoszfáttá (IPP, $\mathrm{C}_{5}$ ) alakul, azon öt szénatomos vegyületté, amelyből minden izoprénvázas vegyület leszármaztatható (3. ábra). Baktériumokban, algákban és a növényi kloroplasztiszokban ettől eltérő, nem-mevalonsav útvonalat (piruvát/glicerinaldehid-3-foszfát reakcióút) is leírtak (Rohmer 1999, Eisenreich és mtsi. 2001, Iturriaga 2001).

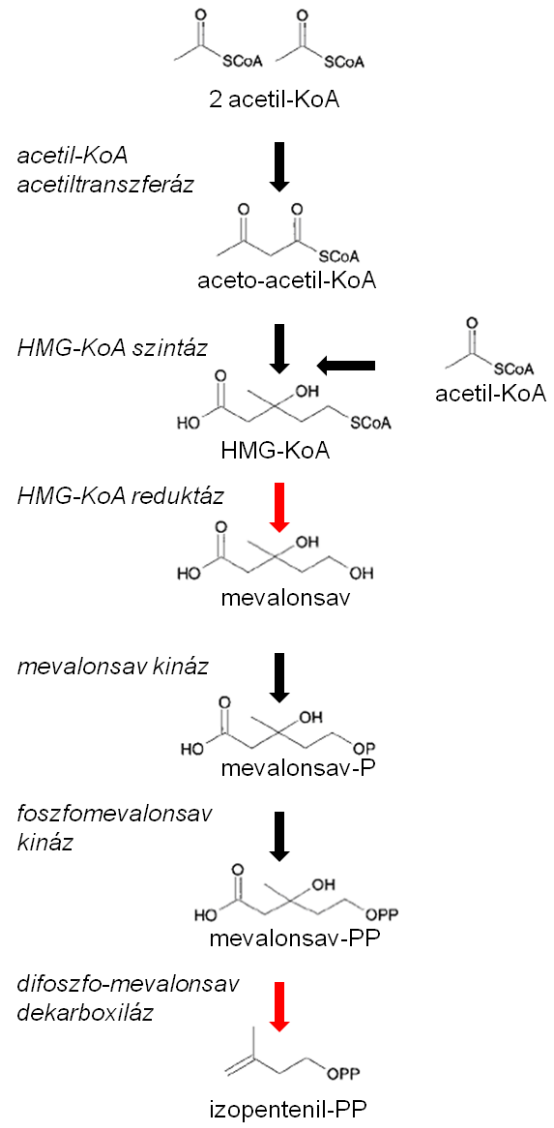

3. ábra. A mevalonsav bioszintézis útvonal, melynek terméke az izopentenil-pirofoszfát, az izoprénvázas vegyületek alapvegyülete. A piros nyíllal jelzett lépések a mevalonsav, illetve az izopentenil-pirofoszfát képződését mutatják. 
Az izoprénvázas vegyületek szintézise (izoprén út)-már függetlenül attól, hogy mely útvonalon képződött az IPP - hasonlóan zajlik minden élőlényben: öt szénatomos egységek kondenzációja eredményezi a lánchosszabbodást. Az IPP-ból egy izomerizációs lépés során (izopentenil-pirofoszfát izomeráz hatására) dimetilallil-pirofoszfát képződik (DMAPP, $\mathrm{C}_{5}$ ), majd ez utóbbi kondenzációja egy IPP molekulával hozza létre a tíz szénatomos geranil-pirofoszfátot ( $\left.\mathrm{GPP}, \mathrm{C}_{10}\right)$. Ezután további IPP egységek beépülésével hosszabbodik a poliprenil lánc (Lee és Schmidt-Dannert 2002). Az ún. prenil transzferázok (E-prenil-difoszfát szintázok vagy prenylPP szintáz enzimcsalád) katalizálják a lánchosszabbodást. Specifitásuk a lánc hosszától függ (Ogura és Koyama 1998), aktivitásukhoz $\mathrm{Mg}^{2+}$ kofaktort igényelnek (Liang és mtsi. 2002). A végső lánchossz szempontjából, e fehérjék több konzervált régiója közül, az első aszparaginsavban gazdag régió (First Aspartate Rich Motif - FARM), azaz a D-D-X ${ }_{2,4}-\mathrm{D}$ motívum és az azt megelőző öt aminosav tünik meghatározónak (Kellogg és Poulter 1997, Ogura és Koyama 1998). Az újabb C-C kötések kialakításához az allélikus szubsztrát és a homoallélikus molekula (azaz az IPP) között a második aszparaginsavban gazdag régió (Second Aspartate Rich Motif - SARM, D-D-X 2 -D motívum) jelentőségét írták le (Ashby és Edwards 1990, Szkopińska és Płochocka 2005). A reakcióút során GPP és farnezilpirofoszfát $\left(\mathrm{FPP}, \mathrm{C}_{15}\right)$ intermediereken keresztül geranilgeranil-pirofoszfát $\left(\mathrm{GGPP}, \mathrm{C}_{20}\right)$ keletkezik, a reakciókat az FPP szintáz és a GGPP szintáz enzimek katalizálják. GPP szintázt ez idáig csak növényekben azonosítottak; valószínüsíthető, hogy gombákban az FPP szintáz felelős a 10 és a 15 szénatomos molekulák képződéséért is (Ogura és Koyama 1998, Szkopińska és Płochocka 2005). Az izoprénvázas vegyületek egyaránt prekurzorai olyan fontos molekuláknak, mint a monoterpének, szeszkviterpének, szteroidok, szterolok, klorofillok vagy a karotinoidok (4. ábra), ugyanakkor valószínüsíthető, hogy a karotinoidok, az ubikinonok és a szteroidok, valamint a triacil-glicerolok bioszintézise külön kompartmentekben zajlik, amelyekben már a prekurzor készletek is elkülönülten vannak jelen. Mindezt járomspórás gombákban sikerült igazolni (Kuzina és mtsi. 2006).

Az eddigi lépések a reakcióút nem karotinoid-specifikus szakaszát alkotják. A karotinoid-specifikus szakaszban két molekula GGPP-ból színtelen fitoén lesz, ezt a lépést a fitoén szintáz enzim katalizálja. A fitoén dehidrogenálását több lépésen keresztül a fitoén dehidrogenáz végzi, ami a molekulán belül, minden egyes lépés során a kettős kötések számának megduplázódásához vezet. A különböző élőlények fitoén dehidrogenázai eltérő típusokba sorolhatók, egyik a CrtI-típus, amely kevésbé szubsztrátspecifikus, három- vagy négylépéses dehidrogénezésre képes, amelytől függően neurosporén vagy likopin keletkezik. Ilyen enzimmel rendelkeznek az archeabaktériumok, az eubaktériumok 
többsége, az anaerob fotoszintetizáló baktériumok és a gombák. Cianobaktériumokban, algákban és növényekben a szubsztrátspecifikusabb CrtP-típus, mely a fitoén - $\zeta$-karotin átalakulást katalizálja, és a CrtQ-típus található meg, ami pedig a $\zeta$-karotin - likopin átalakulásért felel (Iturriaga és mtsi. 2001, Sieiro és mtsi. 2003). Az így képződött neurosporén vagy likopin lehet a karotin-bioszintézis végterméke, de általában továbbalakulnak, így $\mathrm{pl}$. Rhodobacter fajokban a neurosporén szferoidénné és szferoidenonná. Más organizmusokban a likopin molekula egyik vagy mindkét végének jonon-gyürüvé záródása $\gamma$-karotin vagy $\beta$-karotin képződéséhez vezet (5. ábra), utóbbi gyakran a karotinoid-bioszintézis végterméke. A folyamatot a likopin cikláz katalizálja, melynek két típusa a gyakoribb likopin $\beta$-cikláz és a csak növényekben és néhány algában előforduló likopin E-cikláz (Cunningham és Gantt 1998). A likopin $\beta$-cikláz aerob fotoszintetizáló szervezetekben a CrtL-típushoz, más élőlényekben a CrtY-típushoz sorolható.

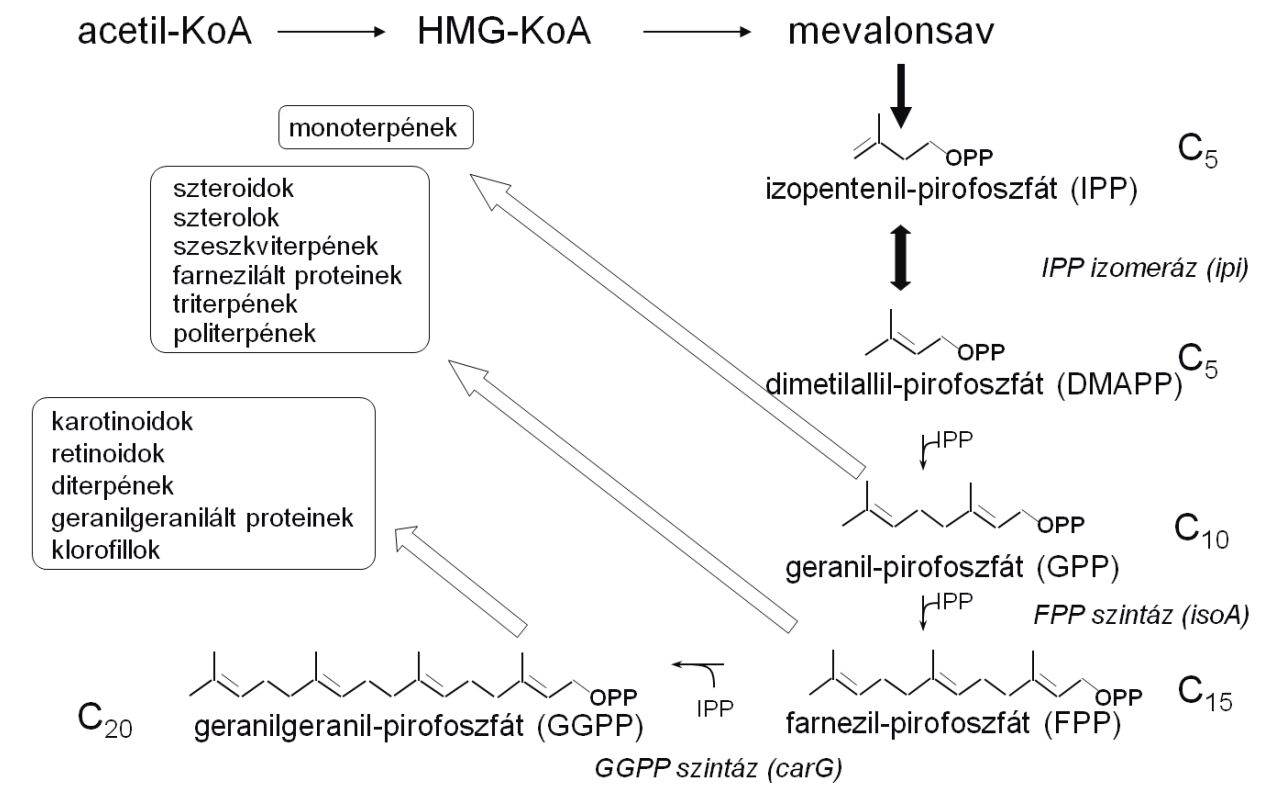

4. ábra. Az izoprénvázas vegyületek bioszintézisének összefoglalása (a 20 szénatomszámú vegyületekig).

A gombákban leírt harmadik típusba tartozó enzimek kettős, fitoén szintáz likopin cikláz aktivitással rendelkeznek. Ilyen pl. a Xanthophyllomyces dendrorhous $\operatorname{crtYB}$ (Verdoes és mtsi. 1999a), a Mucor circinelloides carRP (Velayos és mtsi. 2000b), a Phycomyces blakesleeanus carRA (Arrach és mtsi. 2002) vagy a Neurospora crassa al-2 (Arrach és mtsi. 2001) gének által kódolt fehérjék. Peck és mtsi. (2002) kimutatták a baktériumokban és a gombákban található likopin ciklázok közötti evolúciós kapcsolatot, amiböl egy nagyon érdekes következtetést vontak le: gombákban a likopin cikláz/fitoén 
szintáz enzimeket kódoló gén valójában három gén fúziójával jött létre. Archeákban ugyanis egy génduplikáció következtében a likopin cikláz két kópiában van jelen és egy homodimér fehérjét kódol (Sieiro és mtsi. 2003). Ilyen archeaszerü likopin ciklázt kódoló gének fúziója a fitoén szintázt kódoló génnel vezethetett a gombák kétfunkciós enzimeit kódoló gének kialakulásához.

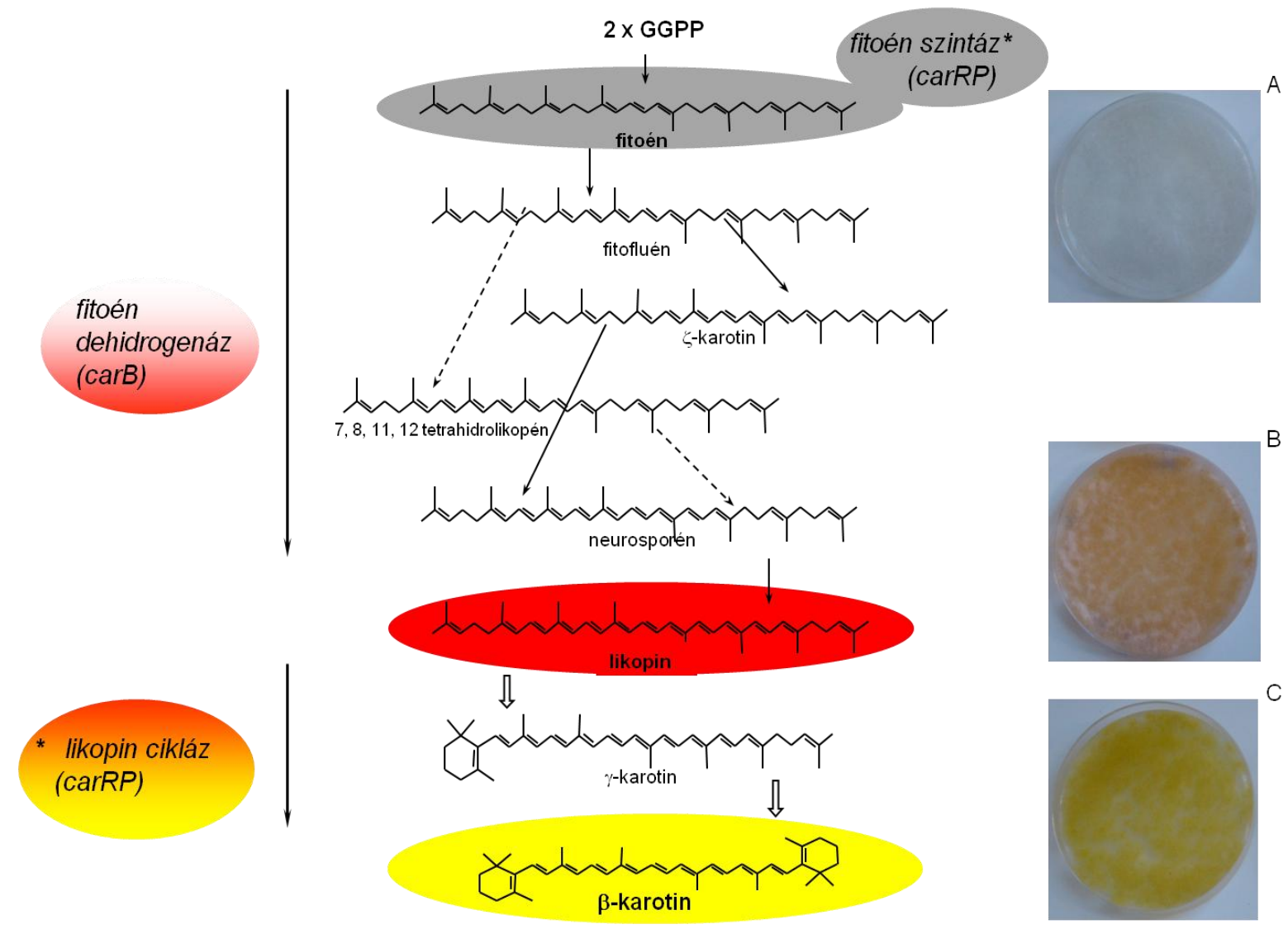

5. ábra. A GGPP-ból kiinduló $\beta$-karotin-szintézis $M$. circinelloides-ben. A csillaggal jelölt enzimeket egy gén ( $\operatorname{carRP}$ ) kódolja. Jobb oldalon két mutáns és a vad típusú törzs fotója látható: A - fitoén dehidrogenáz mutáns törzs, $\mathrm{B}$ - likopin cikláz mutáns törzs, $\mathrm{C}$ - vad típusú törzs.

Számos mikroorganizmusban a $\beta$-karotinból további származékok képződhetnek, ilyenek az oxigéntartalmú funkciós csoportokat (főként hidroxil és oxo csoport) hordozó xantofillok. Ebbe a csoportba tartozik a zeaxantin (3,3'-dihidroxi- $\beta, \beta$-karotin), a kantaxantin ( $\beta, \beta$-karotin-4,4'-dion) és az asztaxantin (3,3'-dihidroxi- $\beta, \beta$-karotin-4,4'-dion) is. A $\beta$-karotin - asztaxantin átalakuláshoz legalább két különböző enzim aktivitása szükséges, egy hidroxiláz és egy ketoláz vagy más néven oxigenáz. Jellemző ezekre az enzimekre, hogy egyszerre csak egy funkciós csoportot tudnak kapcsolni a $\beta$-karotin vázra, ugyanakkor nem csak a $\beta$-karotint tudják szubsztrátként hasznosítani, hanem a saját tevékenységük eredményeként képződő, részlegesen módosított származékokat is. Ebből adódóan a folyamat során változatos köztitermékek képződhetnek. 


\subsection{A karotinoidok bioszintézisének genetikai és molekuláris alapjai gombákban}

Számos gombában, így a járomspórásokban is a karotinoid-bioszintézis végső terméke a $\beta$-karotin (Papp és mtsi. 2009b). A karotinoid-specifikus szakasz három enzimatikus lépésen keresztül játszódik le (ld. 5. ábra). Az ezen enzimeket kódoló géneket már több mikroorganizmusban azonosították és jellemezték. $M$. circinelloides-ben a gének a következők: a carB (2089 bp, egy 61 bp és egy 63 bp intronnal tagolt gén, amely egy 579 aminosav hosszúságú fehérjét kódol, Velayos és mtsi. 2000a), amely a fitoén dehidrogenáz aktivitásért felelős enzimet kódolja és a carRP (1974bp hosszú, egyetlen 61 bp intront tartalmazó gén, amely egy 614 aminosav hosszúságú fehérjét kódol, Velayos és mtsi. 2000b), amely a fitoén szintáz (a fehérje C-terminális része) és a likopin cikláz (a fehérje N-terminális szakasza) aktivitásokat egyaránt meghatározza (6. ábra).

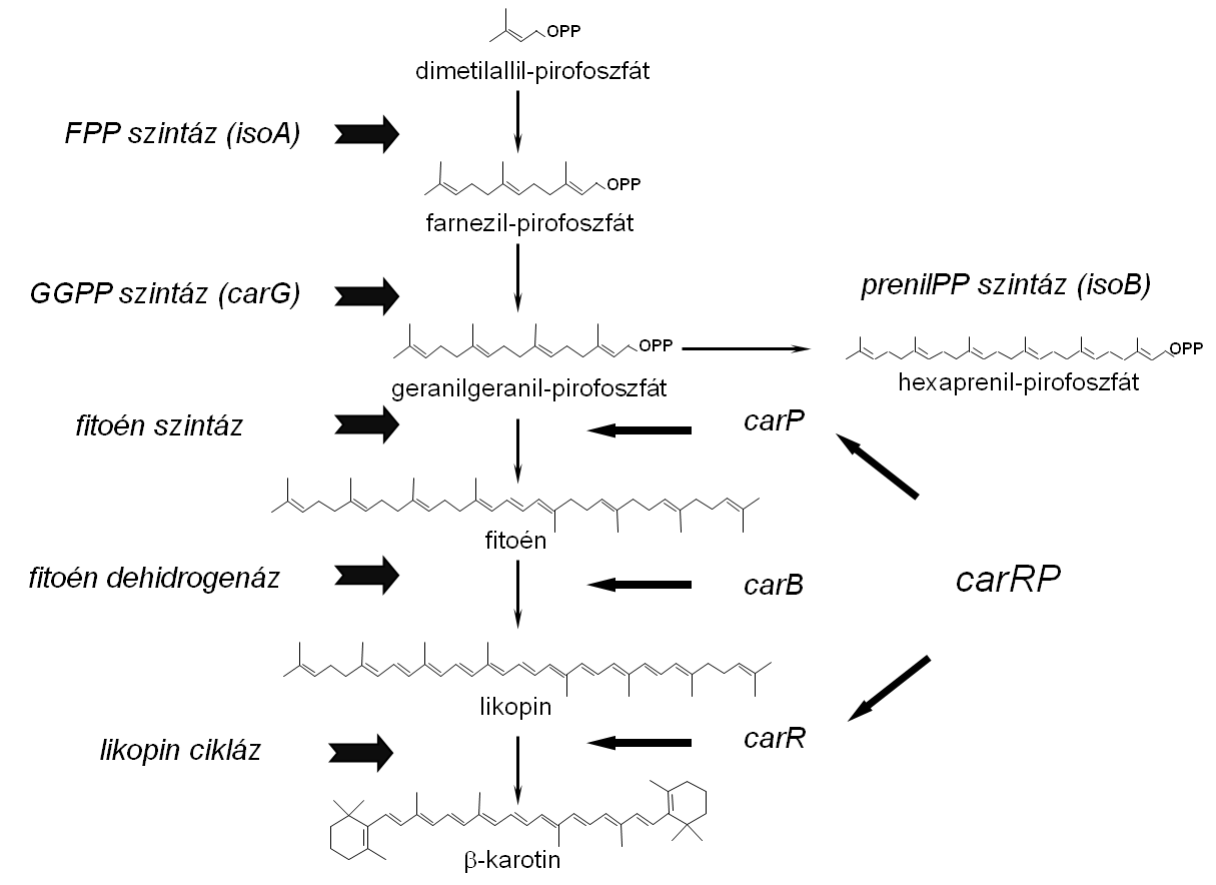

6. ábra. A Mucor circinelloides karotinoid szintézisében résztvevő gének és az általuk kódolt enzimek.

A két gén egymás mellett, egymástól mindössze 446 bp távolságra, ellentétes orientációban, klaszterszerüen helyezkedik el (7. ábra). A két gén müködése összehangolt, közös szabályozás alatt állnak; mindkettő átíródását a kék fény indukálja (Velayos és mtsi. 2000b, Iturriaga és mtsi. 2001). Amennyiben a CarRP fehérje N-terminális szakaszát eltávolítjuk, mind a likopin cikláz, mind a fitoén szintáz aktivitása megszünik, míg ha a Cterminális szakaszt távolítjuk el, a likopin cikláz aktivitás megmarad (Velayos és mtsi. 2000b). Ebböl két dologra lehet következtetni: egyrészt nincs poszttranszlációs módosítás a két fehérje képződésekor, másrészt arra, hogy a fitoén szintáz müködéséhez esszenciális 
a membránon való lehorgonyzás. Az N-terminálison, vagyis a likopin cikláz aktivitásért felelős fehérjerészben található ugyanis a transzmembrán szakaszok nagy része. A $M$. circinelloides $\beta$-karotin szintézisének még bizonyításra váró, multienzimatikus modellje szerint a karotinoidok bioszintézisében résztvevő enzimek - két molekula fitoén szintáz/likopin cikláz, és négy fitoén dehidrogenáz egység - egy komplexet alkotnak. Ez a komplex a membrán kettősrétegébe ágyazódik a CarRP enzim N-terminális régióján keresztül (8. ábra).
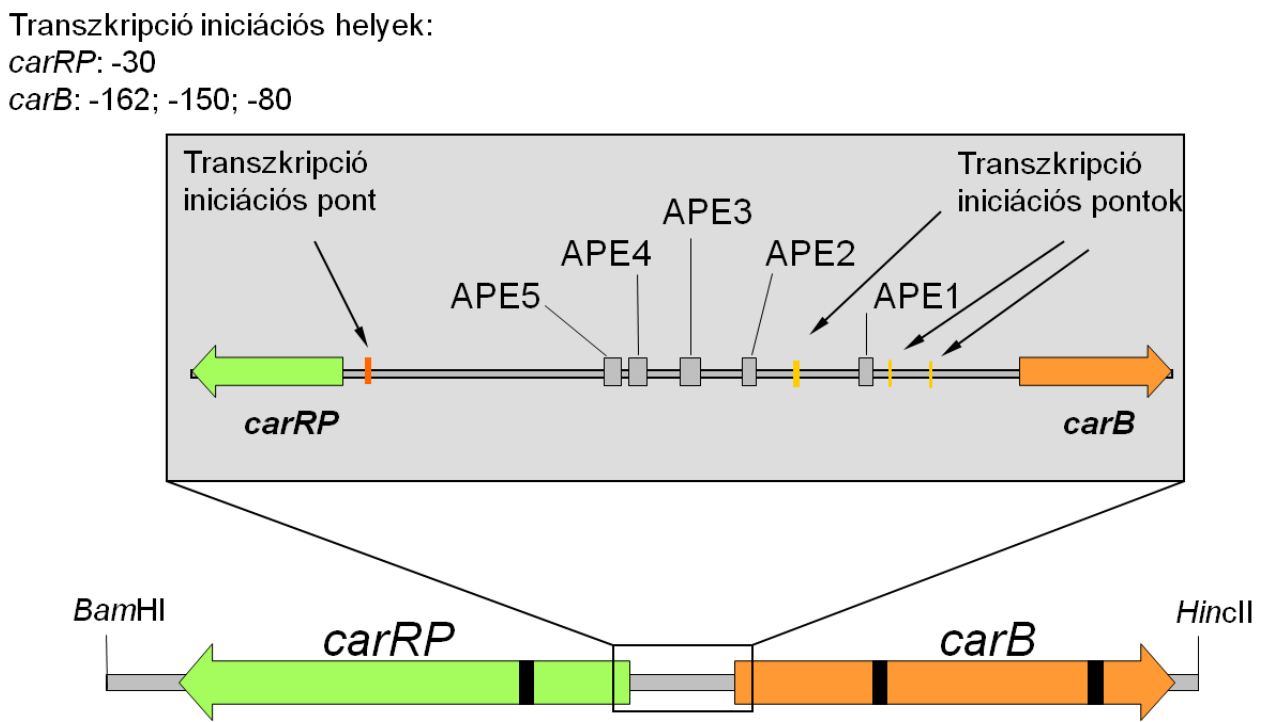

7. ábra. A carRP és a $\operatorname{carB}$ közötti közös intergénikus régió szerkezete (Velayos és mtsi. 2000b, Iturriaga és mtsi. 2001). APE szekvenciák: a Neurospora crassa al-3 gén promóter régiójában található, a fényszabályozásért feltehetően felelős szakaszokkal homológiát mutató szekvenciák.

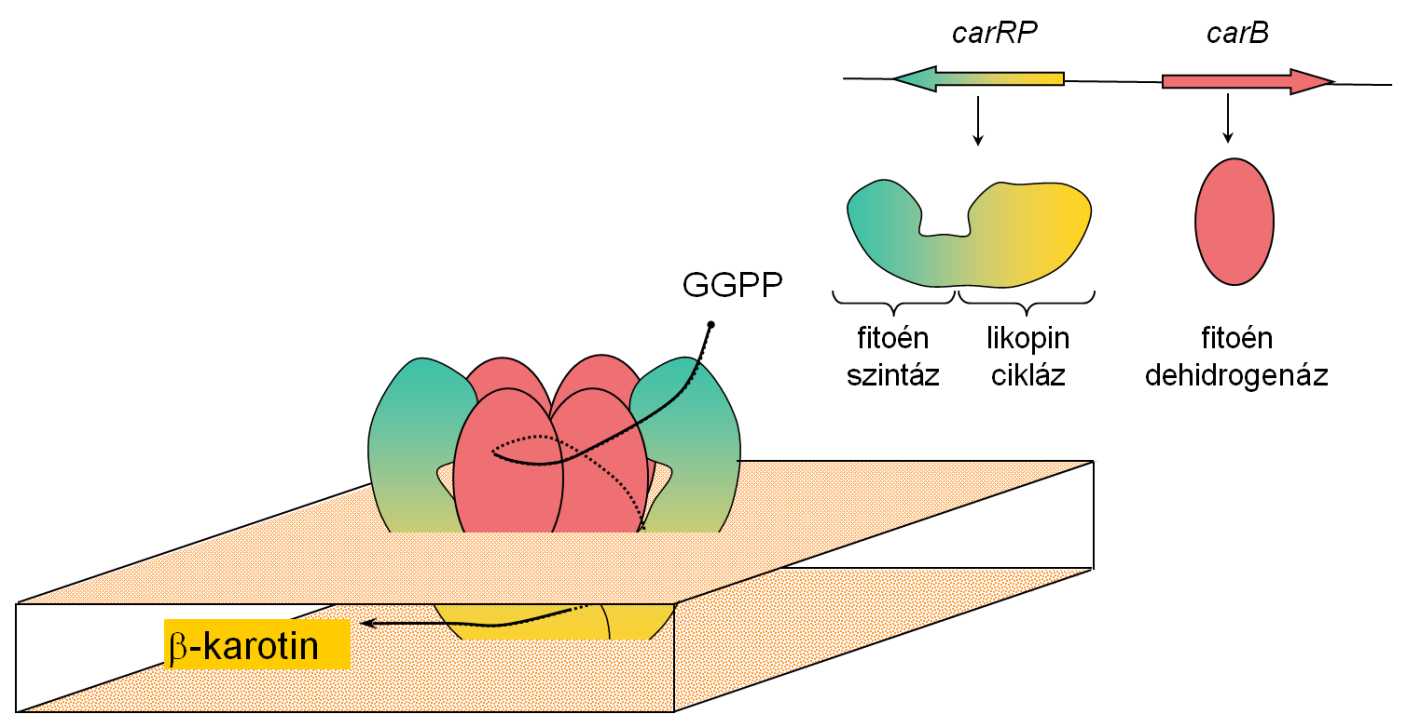

8. ábra. A $\beta$-karotinszintézis multienzimatikus modellje $M$. circinelloides-ben (Iturriaga és mtsi. 2001). 
A spanyol kutatócsoport korábbi kísérletekben már vizsgálta a karotinoidspecifikus gének karotinoid-bioszintézisben betöltött szerepét (Velayos és mtsi. 2000a, 2000b). Több, a karotinszintézis nem specifikus szakaszait meghatározó struktúrgént szintén azonosítottak. Az izoprén út ismert génjei $M$. circinelloides-ben: az isoA, amely a FPP szintázt (Velayos és mtsi. 2004) és a carG (Velayos és mtsi. 2003), amely a GGPP szintázt kódolja. Munkánk során azonosítottuk a $M$. circinelloides IPP izomerázt kódoló ipi génjét is, amely már ismert volt növényekben (Rodríguez-Concepción és Boronat 2002), algákban és élesztőgombákban (Kajiwara és mtsi. 1997). Utóbbiaknál heterológ expressziós rendszerben a gén túlmüködtetése fokozta a karotinoid-termelést. Mindhárom enzim sebesség-meghatározó (rate-limiting) lépéseket katalizál az izoprénvázas vegyületek bioszintézisében, mely egyben azt is jelenti, hogy a karotinok szintézisét is alapvetően meghatározzák. A terpénbioszintézis út génjei általában egy kópiában vannak jelen az élővilágban, de pl. Gibberella fujikuroi-ból két GGPP szintázt izoláltak. A kódolt enzimek általában homodimerek formájában fordulnak elő, kivételt képez néhány baktérium, melyekben a prenylPP szintáz heterodimer, illetve növény, melyekben a GGPP szintáz heterodimer vagy heterotetramer formában fordul elő (Burke és Croteau 2002). M. circinelloides-ben az isoA egy 1491 bp hosszúságú, öt intronnal tagolt (101, 65, 60, 57, 57 bp) gén, mely egy 352 aminosav hosszúságú fehérjét kódol (Velayos és mtsi. 2004), míg az 1461 bp hosszúságú, szintén öt intront tartalmazó (62, 73, 55, 61, 60 bp) carG gén egy 303 aminosavból álló fehérjét kódol (Velayos és mtsi. 2003). A GGPP szintáz jelentőségét a karotinoidok bioszintézisében Neurospora crassa-ban mutatták ki elöször, ahol a GGPP szintázt az al-3 gén kódolja. A gén transzkripcióját, hasonlóan a karotinoid-specifikus szakasz génjeihez, a kék fény indukálja (Carattoli és mtsi. 1994). A hasonló szabályozás is jelzi, hogy a karotinoid-specifikus szakaszt közvetlenül megelőző lépésről van szó, egyben elkülöníti a bioszintézis út korábbi génjeitől, melyek nem fény-indukálhatók (kivétel az isoA, melyet a vörös fény indukál). A Mucor carG génben sikerült azonosítani három rövid, az APE konszenzus szekvenciához hasonló régiót (ld. 7. ábra), amelyek feltehetően felelősek a fényszabályozásért (Velayos és mtsi. 2003). A GGPP egy intermedier vegyület, amelyet a gomba nem akkumulál. A közelmúltban végzett kísérletben a GGPP szintáz túlmüködtetése jelentősen megnövelte a karotintermelést karotintermelő mutáns Escherichia coli törzseken végzett kísérletekben (Wang és mtsi. 1998).

Régóta ismert, hogy a HMG-KoA reduktáz által katalizált lépés az egyik sebességmeghatározó az emlősök koleszterin, valamint a gombák ergoszterin bioszintézisében. Mivel ez a szakasz közös a karotinképzés első szakaszával (mevalonsav út), joggal adódik a kérdés, hogy ez a lépés a karotinoidok szintézisében is hasonló szereppel bír-e. Erre 
vonatkozó adatok csupán az elmúlt néhány évben kerültek napvilágra. Candida utilis ergoszterint termel, de karotinoidokat egyáltalán nem, az izoprén bioszintézis út prekurzorai azonban jelen vannak a gombában. A C. utilist bakteriális heterológ génekkel transzformálva karotintermelést (pl. likopin, $\beta$-karotin, asztaxantin) tudtak kiváltani (Misawa és Shimada 1998). Sikerült izolálni a C. utilis HMG-KoA reduktázt kódoló génjét (hmgl), melyet plazmidba klónozva a karotintermelö törzsbe juttattak, így a több kópiában jelenlevő hmgl gén túlmüködésének köszönhetően a karotinmennyiség (a kísérletben likopin) a négyszeresére nőtt, míg az ergoszterin mennyisége alig változott. Laboratóriumunkban izolálták és jellemezték a Rhizomucor miehei HMG-KoA reduktázt kódoló hmg génjét, melyet heterológ rendszerben expresszáltattunk $M$. circinelloides-ben, de ott nem eredményezett változást a karotinoid termelésben (Vágvölgyi és mtsi. 2004, Lukács és mtsi. 2009). Tanszékünkön jelenleg is folyamatban van a $M$. circinelloides mevalonsav útvonalban résztvevő enzimeket (HMG-KoA reduktáz, HMG-KoA szintáz, mevalonsav kináz, difoszfo-mevalonsav dekarboxiláz) kódoló gének izolálása és jellemzése.

Ahogy egyre több, a karotin-bioszintézisben szerepet játszó gént azonosítanak, a kutatók egyre nagyobb lehetőséget látnak a mikrobákkal megvalósítható heterológ karotintermelésben. Újabban sikeresen fejeztettek ki bakteriális (Erwinia, Paracoccus, Alcaligenes), karotin bioszintézisért felelős géneket eredendően karotint nem-termelő baktériumokban, így pl. E. coli-ban (Misawa és mtsi. 1995, Fraser és mtsi. 1997, Kajiwara és mtsi. 1997, Misawa és Shimada 1998, Wang és mtsi. 1998), illetve élesztőkben pl. Candida (Misawa és Shimada 1998, Shimada és mtsi. 1998) és Saccharomyces törzsekben (Misawa és Shimada 1998). A módosított mikrobák, a bejuttatott géntől függően, különböző karotinoidokat (likopin, asztaxantin, kantaxantin, zeaxantin, $\beta$-karotin) termeltek (Schmidt-Dannert 2000). Rendelkezésünkre állnak az asztaxantin termelésére képes tengeri baktérium, a Paracoccus sp. N81106 törzs (MBIC 01143, korábban Agrobacterium aurantiacum) karotinoid szintézisért felelős génjei. Az öt gén és az általuk kódolt enzimek a következők: $c r t B$-fitoén szintáz, crtI-fitoén deszaturáz, $\operatorname{cr} Y$-likopin cikláz, crtW- $\beta$-karotin ketoláz, és crtZ- $\beta$-karotin hidroxiláz. Ezek a gének egyetlen génklasztert alkotnak. Paracoccusban az asztaxantin (3,3'-dihidroxi- $\beta, \beta$-karotin-4,4'-dion) $\beta$-karotinból történő, több köztiterméken keresztüli képződéséért 2 enzim: a $\beta$-karotin ketoláz és a $\beta$-karotin hidroxiláz a felelősek. Az enzimeknek kettős aktivitásuk van, így a $\beta$-karotin hidroxiláz a $\beta$-karotint és a $\beta$-kriptoxantint zeaxantinná, ugyanakkor a kantaxantint és a fönikoxantint (3-hidroxi- $\beta, \beta$-karotin-4,4'-dion) asztaxantinná képes alakítani, míg a $\beta$-karotin ketoláz a $\beta$-karotint és az ehinenont ( $\beta$, $\beta$-karotin-4-on) 
kantaxantinná, a zeaxantint és az adonixantint (3,3'-dihidroxi- $\beta, \beta$-karotin-4-on) szintén asztaxantinná alakítja. A 9. ábra a Paracoccus sp. N81106 törzs $\beta$-karotinból kiinduló asztaxantin bioszintézisének lépéseit ábrázolja.

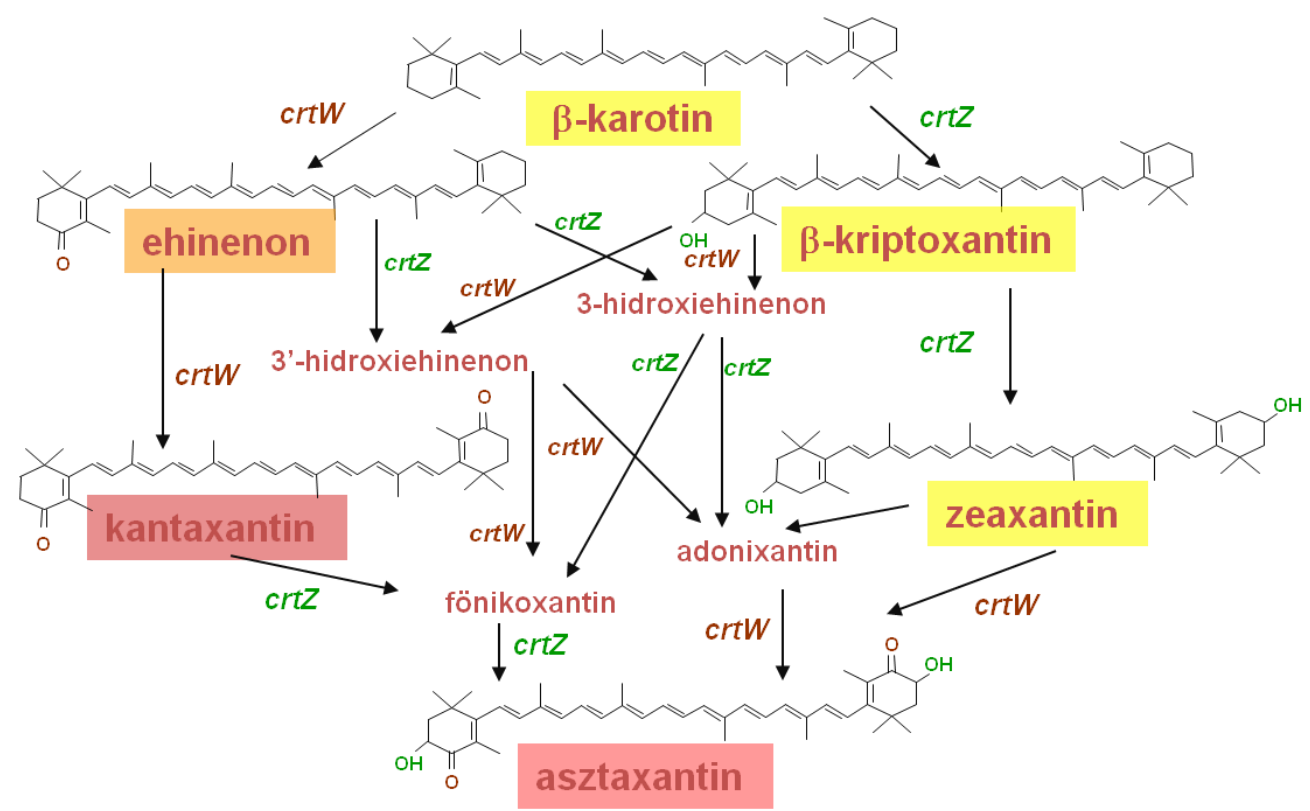

9. ábra. Az asztaxantin bioszintézis útja Paracoccus sp. N81106 törzsben, az egyes lépéseket katalizáló enzimek génjeivel jelölve: $c r t Z$ - $\beta$-karotin hidroxiláz, $\operatorname{crt} W$ - $\beta$-karotin ketoláz.

\subsection{Járomspórás gombák a karotin-bioszintézis kutatásában}

Az utóbbi időben egyre több kutatás foglakozik a gombák karotinoid bioszintézisével (Iturriaga és mtsi. 2005). A $\beta$-karotintermelő mikrobák közül mind elméleti, mind pedig gyakorlati szempontból kiemelkedő jelentőséggel bírnak a járomspórás gombák közé tartozó Mucorales rend tagjai (Papp és mtsi. 2009b). Ezekben a gombákban a karotintermelés szorosan összefügg a párosodási folyamatokkal (Schimek és mtsi. 2003). Sok fajnál az ellentétes párosodási típusba tartozó micéliumok érintkezési zónájában élénksárga szín figyelhető meg, jelezve a $\beta$-karotin akkumulációját a zigofórokban (Lampila és mtsi. 1985). Az ivaros folyamatokban fontos szerepet játszó, a zigofórok képződését stimuláló feromonok (a trispórsav és származékai) is $\beta$ karotinszármazékok (Navarro és mtsi. 2000). A trispórsavak, akár a párosodási folyamatoktól függetlenül is serkenthetik a $\beta$-karotin termelödését. Ezt a hatást eddig csak járomspórás gombáknál mutatták ki.

A karotin-bioszintézis biokémiai és genetikai tanulmányozásának régóta használt modellorganizmusai a Phycomyces, a Blakeslea és a Mucor nemzetség tagjai. Részletesen vizsgálták a Phycomyces blakesleeanus karotin bioszintézisének folyamatát. E faj esetében vizsgálták legalaposabban a karotinoidok jelentőségét a fény érzékelésében, valamint azt is 
igazolták, hogy a $\beta$-karotintermelés növekedésével párhuzamosan nő a zsírsavtermelődés is (Cerdá-Olmedo és Avalos 1994). Az ipari felhasználás szempontjából ez nagy jelentőségü, mivel a $P$. blakesleeanus elsősorban az emberi táplálkozásban is fontos szereppel bíró telítetlen zsírsavakat (pl. $\gamma$-linolénsav) termel (Stred'anská és Šajbidor 1992). Eddig azonban egyetlen genetikai transzformációs rendszert sem tudtak sikerrel alkalmazni Phycomyces esetében, ami egyelőre határt szab a további kutatásoknak. Jelenleg az egyetlen ipari $\beta$-karotin termeltetésre használt járomspórás gombafaj a Mucorales rendbe tartozó Blakeslea trispora, amit föként Ukrajnában, Oroszországban és újabban Spanyolországban alkalmaznak (Iturriaga és mtsi. 2001, Dufossé 2006). Ennél a gombánál többféle módszert alkalmaztak a karotintermelés fokozásának érdekében, többek között növekedést befolyásoló vegyületek adagolását a termeltetés során, túltermelő mutáns törzsek szelektálását, párosodási folyamatokkal képzett interszexuális heterokarionok alkalmazását (Mehta és mtsi. 2003). Ezekkel a módszerekkel azonban csak bizonyos mértékig tudták fokozni a gomba karotin termelését. Emellett a $B$. trispora-ra vonatkozó molekuláris biológiai ismereteink meglehetősen hiányosak és a P. blakesleeanus-hoz hasonlóan itt sem áll rendelkezésre megfelelő transzformációs rendszer (Iturriaga és mtsi. 2005).

Az utóbbi években a $M$. circinelloides került a kutatások középpontjába. Ez a gomba rendelkezik néhány, a karotin-bioszintézis vizsgálata és a karotin termeltetés szempontjából igen előnyös tulajdonsággal. Ilyen például a hatékony genetikai transzformáció lehetősége, a heterológ gének kifejeződése, a morfológiai dimorfizmus jelensége, vagyis az a tulajdonságuk, hogy bizonyos körülmények között élesztőszerü növekedésre képesek. Ez a tulajdonságuk nagyon hasznos az ipari felhasználás során, mivel lehetővé teszi a folyékony tápközegben történő fermentációt ("submerged" növekedést), így a biomassza is nagyobb és a sejteket is könnyebb elválasztani a tenyésztési közegtől (Orlowsky 1994). Mindezek mellett számos, karotin termelésében megváltozott mutáns törzset izoláltak (Velayos és mtsi. 1997). Több, a karotinszintézissel kapcsolatos gén szekvenciája ismert, sokat közülük részletesen jellemeztek is pl. carB, carRP, isoA, carG (részletesen lásd a 3.4. fejezetben). Ipari szempontból további jelentőséggel bír, hogy a karotinoid termelés fokozása a gombában növeli az emberi táplálkozás számára ugyancsak előnyös telítetlen zsírsavak termelődését is.

\subsection{Járomspórás gombák genetikai transzformációja}

A gének funkciójának és kifejeződésük szabályozásának vizsgálatához, valamint az ipari szempontból jelentős gombatörzsek genetikai módosításához nélkülözhetetlen a stabil 
transzformánsokat eredményező, hatékony transzformációs rendszerek megléte. Általános követelmény a transzformációkkal kapcsolatosan, hogy a transzformáló DNS bejusson az adott organizmusba, ott stabilan fennmaradjon, replikálódjon és a rajta található gén(ek) kifejeződjön(ek). 1978-ban közölték az első gomba (Saccharomyces cerevisiae) sikeres PEG-mediált transzformációját, melyhez nagy elörelépést jelentett az élesztőkben is müködő E. coli inga (shuttle) vektorok kifejlesztése (Beggs 1978, Hinnen és mtsi. 1978). Ezt sorra követték a különféle gombafajokkal végzett kísérletek (Fincham 1989, CasasFlores és mtsi. 2004). Hat évvel az első gombatranszformációt követően a $M$. circinelloides, az első járomspórás gomba sikeres transzformációját is leírták (van Heeswijck és Roncero 1984).

Járomspórás gombák esetében nehézséget jelent, hogy a más gombáknál rutinszerüen alkalmazott módszerek gyakran nem használhatók, emellett az ismereteink igen hiányosak a bejuttatott DNS fennmaradását illetően is (Skory 2002, 2004, 2005, Ibrahim és Skory 2006). A járomspórás gombák módosítására a PEG-mediált protoplaszt transzformáció a leggyakrabban alkalmazott módszer (van Heeswijck és Roncero 1984, Appel és mtsi. 2004), ugyanakkor a hifákból vagy spórákból történő protoplasztképzés sok faj esetében nehézkes (gyakran a sejteket körülvevő anyagok miatt). Tovább nehezíti a módszer alkalmazhatóságát a sejtfalukat felépítő kitin és kitozán polimereket bontó enzimeket tartalmazó gyári készítmények hiánya (Jung és mtsi. 2000). Az utóbbi néhány évben az elektroporáció, a biolisztikus, az Agrobacterium tumefaciens-közvetített transzformáció (ATMT) valamint egy esetben az Agrobacterium rhizogenes-közvetített transzformáció (ARMT) módszerét is sikerrel alkalmazták járomspórás gombák esetében (ld. 1. melléklet). A járomspórás gombák transzformációjáról alkotott legfontosabb ismereteket egy könyvfejezetben foglaltuk össze (Papp és mtsi. 2009a).

Ismert, hogy a járomspórás gombákba, az alkalmazott transzformációs módszertől függetlenül, a bejuttatott cirkuláris DNS, eltérően a más gombáknál tapasztaltaktól, autonóm replikálódó extrakromoszómális elemként marad fenn. Érdekes, hogy ehhez nem szükséges az autonóm replikációt biztosító szakasz (ARS) megléte (van Heeswijck és Roncero 1984, Revuelta és Jayaram 1986, Wöstemeyer és mtsi. 1987, Benito és mtsi. 1995, Skory 2002). A genomba történő integráció nagyon ritka esemény, még akkor is, ha a bejuttatott plazmid nagyobb, a gazdagenommal homológ szakaszokat hordoz (Arnau és mtsi. 1991, Arnau és Stroman 1993, Wada és mtsi. 1996, Yamazaki és mtsi. 1999, Wolff és Arnau 2002, Skory 2002, 2004, 2005). Cirkuláris plazmid alkalmazása viszonylag magas transzformációs gyakoriságot eredményezhet, ugyanakkor a plazmid kópiaszáma alacsony marad a transzformánsokban, ami mitótikus instabilitáshoz vezet (Ibrahim és 
Skory 2006). Kimutatták, hogy a DNS koncentráció növelésével nem növekszik lineárisan a transzformációs gyakoriság (Revuelta és Jayaram 1986), valamint a transzformációs gyakoriság nem függ a plazmid méretétől, sokkal inkább annak szekvenciájától (Arnau és mtsi. 1988). Az integráció kikényszeríthető, ha olyan lineáris fragmentummal transzformálunk, mely a végein a kettős rekombinációt irányító, kiterjedt homológ szakaszokat hordoz. Amíg élesztőkben ehhez 50-80 bp-nyi szakasz elengendő, addig járomspórás gombákban 500 bp-nál hosszabb homológ szakaszok szükségesek. A kettős homológ rekombináció eredménye a génkicserélődés vagy más néven szubsztitúció (Arnau és Stromann 1993, Skory 2002). A transzformációs gyakoriság azonban ilyenkor nagyon alacsony marad, feltehetőleg egy, a gazda genomot védő mechanizmusnak köszönhetően, amely meggátolja az idegen DNS genomba történő integrációját és fennmaradását (Obraztsova és mtsi. 2004, Ibrahim és Skory 2006). Ezt igazolja, hogy szinte minden vizsgált esetben igazolható volt a bejuttatott DNS csonkolódása, valamint átrendeződések, deléciók vagy akár a transzformáló vektor teljes eliminációja (Burmester és mtsi. 1990, Yanai és mtsi. 1990, 1991, Burmester 1992, Arnau és mtsi. 1991, Mackenzie és mtsi. 2000, Monfort és mtsi. 2003). Ilyen genomot védő mechanizmus meglétét már több gombában igazolták: ilyen mechanizmus $N$. crassa-ban a RIP (repeat induced point mutation) és a quelling (transgene-induced gene-silencing, Cambareri és mtsi. 1991, Romano és Macino 1992), Ascobolus immersus-ban a MIP (methylation induced premeiotically, Rhounim és mtsi. 1992) és Phytophtora infestans-ban a transnuclear transcriptional gene silencing (van West és mtsi. 1999). Feltehetőleg hasonló folyamatok járomspórás gombákban is lejátszódhatnak, ezt azonban eddig nem sikerült igazolni. A bejuttatott idegen DNS feldarabolódását és eliminációját ugyanakkor már számos publikációban leírták.

További nehézséget jelent, hogy a járomspórás gombákba bejuttatott lineáris fragmentumok könnyen cirkularizálódnak (mivel lineáris fragmentum nem marad fenn járomspórás gombákban), illetve több fragmentum összekapcsolódásával óriásmolekulák (konkatamerek) jöhetnek létre, amelyek extrakromoszómális elemekként maradhatnak fenn. Valószínű, hogy még két különböző restrikciós enzimmel történő linearizálás sem garantálja a recirkularizáció elkerülését és az integráció lejátszódását (Skory 2005). Amennyiben megtörténik az integráció, a bejuttatott DNS általában egy kópiában épül be a genomba, habár az ARMT módszer esetében kétkópiás integrációt írtak le (Wei és mtsi. 2010) Megtörténhet ugyanakkor a fragmentumok összekapcsolódása és integrációja is, ami tandem-ismétlődő, több kópiás integrációt eredményez.

Számos gomba esetén az integráció úgy is elérhető, ha a protoplasztokhoz a transzformáló lineáris fragmentum mellett azokat a restrikciós endonukleázokat is 
hozzáadjuk, amelyekkel linearizáltuk vektorunkat. Ilyenkor a sejtmagba bejutó lineáris fragmentum mellett az emésztő enzimek is bejutnak, majd a magi DNS darabolása után, az újbóli összerendeződésekor, kis valószínűséggel előfordulhat az idegen DNS beépülése a genomba (Maier és Schäfer 1999, Mullins és Kang 2001). Ezt nevezzük restrikciós enzimmediált integrációnak (REMI, 10. ábra), melyet ez idáig sikertelenül alkalmaztak járomspórás gombák esetében. A módszerrel többé-kevésbé random integráció érhető el. Hátrányai között említhető, hogy mivel PEG-mediált protoplaszt transzformáción alapul, megköveteli a protoplasztok képzését, emellett gyakran eredményez nagyobb kromoszóma mutációkat, pl. deléciókat, inverziókat, átrendeződéseket (Sweigard és mtsi. 1998, Linnemannstöns és mtsi. 1999).

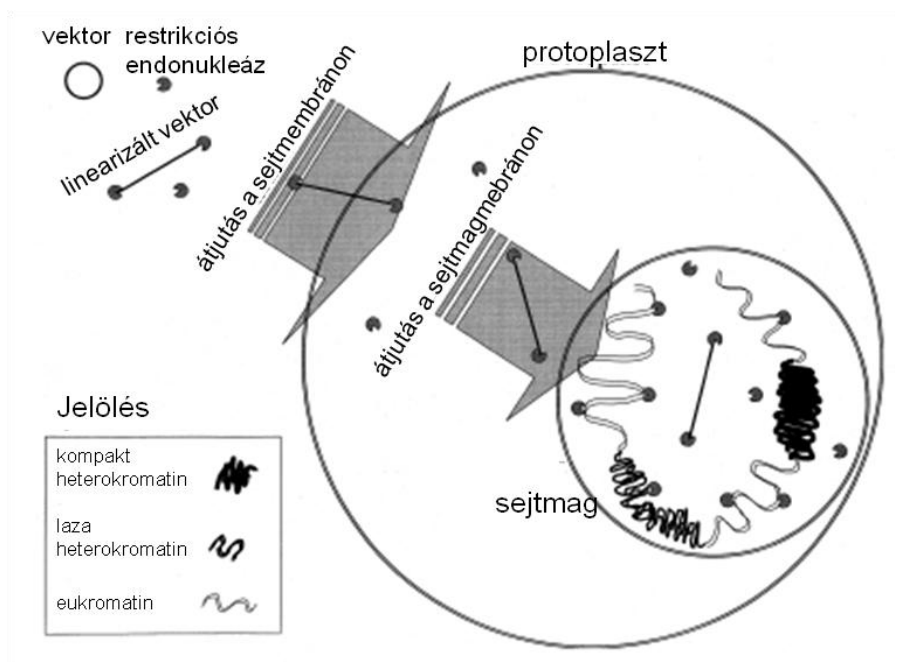

10. ábra. A REMI folyamatának elméleti háttere (Maier és Schäfer 1999 alapján).

Az ATMT egy, a növényeknél már régóta, gombáknál csak az elmúlt néhány évben alkalmazott módszer (Bundock és mtsi. 1995, de Groot és mtsi. 1998). Mára már a $M$. circinelloides, Backusella lamprospora, Rhizomucor miehei, Rhizopus oryzae valamint Mortierella alpina járomspórás gombafajoknál is sikeresen alkalmazták ezt a módszert (1. melléklet). Az A. tumefaciens egy talajlakó Gram negatív baktérium, amely tumorosodást okoz kétszikü növényekben. A baktérium sejteket a sebzett növényi szövetekböl kiáramló fenolszármazékok (pl. acetosziringon) a sebhez vonzzák (Kado 1991), és a növényi jelmolekulák a baktériumok tumor indukáló (Ti) plazmidján található vir gének expressziójának indukcióját okozzák (Li és mtsi. 2000, Michielse és mtsi. 2005). Az egyszálú T-DNS régió (a Ti plazmid része) kivágódásáért, védelméért, a növényi sejtekbe történő bejutásáért, valamint a genomba történő integrációjáért a vir gének által kódolt fehérjék felelősek. A növényi genomba beépülő T-DNS régióról növényi hormonok 
expresszálódnak, amelyek kontrollálatlan sejtburjánzást, azaz tumorosodást eredményeznek. E T-DNS régió két végén egy-egy 24 bázisos, ismétlődő szekvencia található (LB és RB régió), a közöttük lévő tumorképződés indukciójához szükséges, valamint a baktérium sejtek növekedése szempontjából fontos növényi eredetü opinok bioszintézisét és felhasználását biztosító gének azonban nem szükségesek a T-DNS régió transzferéhez. A két határoló régió közötti szakasz kivágható és helyére tetszőleges gének illeszthetők be, így a tumorképző képességüket elvesztett baktériumok mesterséges génátvitelre használhatók. Az ATMT alapját bináris Ti vektorok képezik. Külön plazmid hordozza a T-DNS régiót a transzformálni kívánt génekkel és külön úgynevezett helper plazmid a T-DNS átjutását és genomba történő integrációját biztosító vir géneket; mindkettő nélkülözhetetlen a transzformációhoz (11. ábra).

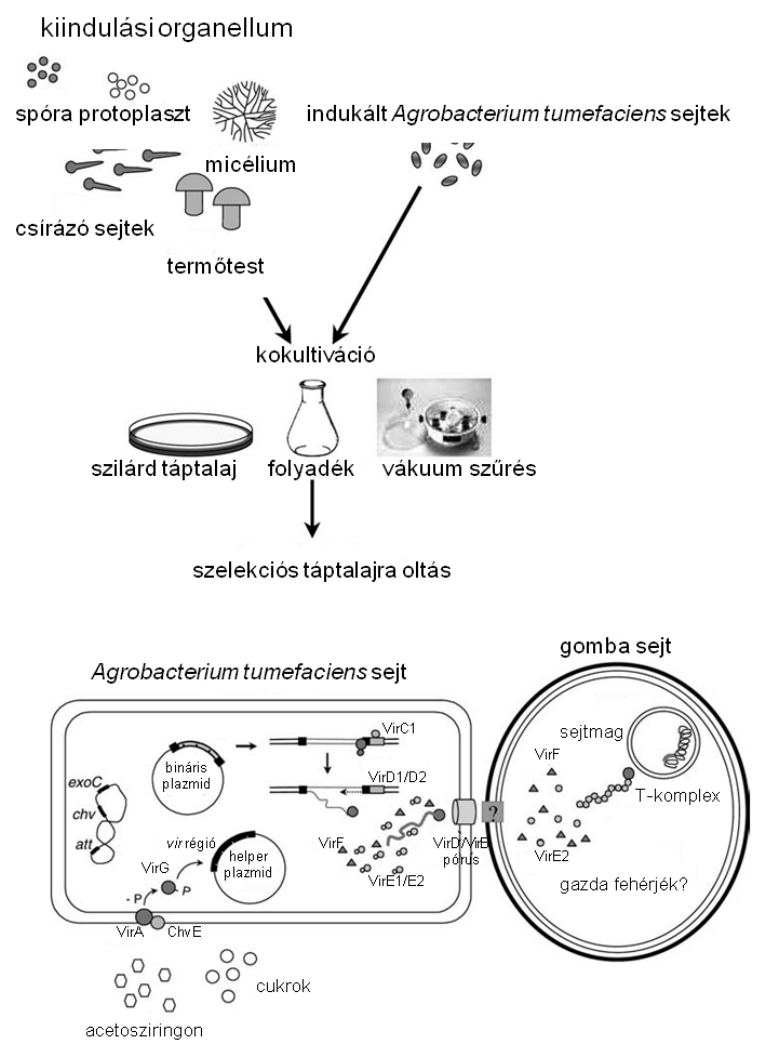

11. ábra. Az ATMT folyamatának elméleti háttere (Michielse és mtsi. 2005 alapján)

A módszer nagy előnye, hogy közvetlenül spórák és hifák is transzformálhatók így nem igényli protoplasztok képzését. Ugyanakkor a sikeres transzformációhoz fontos a baktérium és gomba sejtek együtt-tenyésztési paramétereinek optimalizálása. Az ATMT szinte minden esetben egy kópiás integrációt eredményez, heterológ helyre, és akár $150 \mathrm{~kb}$ hosszúságú DNS szakasz gazdagenomba történő építésére is alkalmas (Hamilton és mtsi. 1996). Kimutatták, hogy gyakran a genom ugyanazon lókuszába történik az integráció, 
kijelölve ún. „hot spot”-okat (Michielse és mtsi. 2004), ugyanakkor kiterjedt homológ szakaszokkal az irányított integráció is elérhető. A határoló szekvenciákon kívüli rész nem integrálódik a genomba, valamint gyakran a T-DNS régió is csonkolódik. Az ATMT segítségével olyan gombafajokat is sikerrel transzformáltak, amelyeket hagyományos módszerekkel nem vagy csak nehézkesen sikerült, így pl. Agaricus bisporus (Chen és mtsi. 2000, Mikosch és mtsi. 2001), Calonectria morganii (Malonek és Meinhardt 2001), Fusarium circinatum (Covert és mtsi. 2001), Helminthosporium turcicum (Degefu és Hanif 2003) fajokat.

Sikeres integrációs események után a járomspórás gombák cönocitikus felépítésének, valamint a multinukleáris protoplasztoknak/spóráknak köszönhetően további nehézséget jelent a stabil integratív transzformánsok homokariotikus állapotban történő izolálása. A többmagvú protoplasztokbók fejlődő hifák ugyanis heterokariotikusak, azaz genetikailag különböző magokat tartalmaznak. A hifák növekedésekor a cönocitikus micéliumban a sejtmagok szegregálnak, így néhány tenyésztési ciklus után homokarionok jönnek létre.

A transzformánsok szelekciója szintén okozhat nehézséget a járomspórás gombáknál. A leggyakrabban valamilyen auxotrófia komplementálása (leucin, uracil, metionin, arginin) használatos, azonban ez mutáns törzsek meglétét igényli. Az integráció és ebből adódóan az irányított génkiütés nehézkes, így a leggyakrabban valamilyen hagyományos mutagenezissel (elsősorban fizikai, pl. UV-mutagenezis) előállított auxotróf mutánst használnak. A random mutagenezist eredményező módszerek azonban egyéb nemkívánt, nehezen kiszürhető mutációkat is eredményezhetnek. Ritka spontán mutációkra is lehet szelektálni, így pl. FOA (fluoro-orotsav) tartalmú táptalajon, ahol uracil auxotróf mutánsok izolálhatók. Domináns szelekciós markerek alkalmazásával ugyanakkor kiváltható az auxotróf mutánsok előzetes létrehozása. Gyakran valamilyen bakteriális eredetü drogrezisztenciát biztosító gént (pl. hygromycin, neomycin, vagy kanamycin rezisztencia gén) alkalmaznak szelekciós markerként. Járomspórás gombák esetében azonban további problémát okozhat a nagyfokú alaprezisztencia számos, különféle antifungális hatású vegyülettel szemben (van Heeswijck és mtsi 1988). Domináns szelekciónak minősül az is, ha egy egyébként a mikroorganizmus számára nem hasznosítható szubsztrát hasznosíthatóvá válik a szubsztrát felhasználását lehetővé tévő enzimet kódoló gén bejuttatásával. Ilyen célból sikerrel alkalmazták már számos gomba, köztük a járomspórás $R$. oryzae esetében is az Aspergillus nidulans acetamidázt kódoló amdS génjét. A transzformánsok képesek voltak az acetamid egyedüli nitrogénforrásként való hasznosítására (Michielse és mtsi. 2004). 
Rendelkezésünkre állt a leucin és uracil auxotróf mutáns $M$. circinelloides MS12 törzs, munkánk során végig ezzel a törzzsel dolgoztunk. A kettős auxotrófia lehetővé tette, hogy egyidejűleg két plazmiddal transzformáljuk az MS12 törzset. A jövőben más járomspórás gombák genetikai módosításához auxotróf mutáns törzsek hiányában szükségesnek tünik domináns szelekciós markerek alkalmazása is. A tanszéki kutatócsoport jelenleg is folytat ilyen irányú kísérleteket.

Nagy előnye a $M$. circinelloides-nek más gombákkal szemben, hogy a nem-rokon szervezetekből származó heterológ gének is viszonylag jól kifejeztethetők benne (Iturriaga és mtsi. 1992, 2001, Ruiz-Hidalgo és mtsi. 1999, Wolff és Arnau 2002, Papp és mtsi. 2006). A heterológ eredetű gének kifejeződéséhez több Mucor gén szabályozó régiója is alkalmas lehet. A legígéretesebbnek a glicerinaldehid-3-foszfát dehidrogenáz enzim promótere tünik. Ezt az általában konstitutívan és erősen kifejeződő gént már számos gomba esetében felhasználták transzformációs rendszerek létrehozásához (Wolff és Arnau 2002). A M. circinelloides gpdl gént (EMBL azonosító: AJ293012) azonosították és részletesen jellemezték (Wolff és Arnau 2002). A Mucor gpdl gén expressziója jelentősen növelhető, ha a gombát glükóz tartalmú táptalajon tenyésztjük és fokozzuk a glükóz koncentrációját (Wolff és Arnau 2002, Larsen és mtsi. 2004).

A $M$. circinelloides kétszeres auxotróf mutáns MS12 törzsét számos előnyös tulajdonsága, mint a hatékony genetikai transzformáció lehetősége, a heterológ gének kifejeződése vagy a szelekciós rendszerek megléte egyaránt a kutatások egyik modellorganizmusává tette. 


\section{CÉLKITŰZÉSEK}

Munkánk során célul tüztük ki, hogy rekombináns technikákat, valamint a genetikai transzformáció különféle eljárásait alkalmazva a $M$. circinelloides karotinoid bioszintézisét úgy módosítsuk, hogy a létrehozott törzsek $\beta$-karotin termelése növekedjen, illetve a $\beta$-karotinon kívül más értékes karotinoidok (pl. asztaxantin és kantaxantin) termeltetése is lehetővé váljon. Célunk volt az is, hogy olyan a genetikai transzformációra, illetve a transzformánsok jellemzésére alkalmas módszereket dolgozzunk ki, illetve optimalizáljunk, melyek eredményesen használhatók fel a fonalas gombák karotin termelésének befolyásolását célzó elméleti és alkalmazott kutatások során.

Munkánk során ezért a következő konkrét célok megvalósítását tüztük ki:

1. A M. circinelloides kétszeres auxotróf mutáns MS12 törzs karotinoid termelésének módosítása olyan xantofillok termeltetése érdekében, amiket a gomba eredetileg nem szintetizál. Ezt a Paracoccus sp. N81106 törzs asztaxantintermelő tengeri baktérium génjeit hordozó autonóm replikálódó expressziós vektorokkal kívántuk megvalósítani.

2. A M. circinelloides MS12 törzs izopentenil-pirofoszfát izomerázt kódoló génjének klónozása és jellemzése. Az MS12 törzs $\beta$-karotin termelésének fokozása három, a nem karotinoid-specifikus izoprén bioszintézis út génjeit (ipi, isoA és carG) hordozó autonóm replikálódó expressziós vektorok segítségével.

3. A xantofillok termeltetéséhez szükséges bakteriális eredetű gének integrációja a gomba genomjába különböző transzformációs rendszerek alkalmazásával. 


\section{ANYAGOK ÉS MÓDSZEREK}

\subsection{A kísérletek során alkalmazott törzsek}

Transzformációs kísérleteink során a Mucor circinelloides f. lusitanicus (CBS 277.49 izolátum) leuA és pyrG kétszeres auxotróf mutáns MS12 törzset alkalmaztuk (Benito és mtsi. 1992, SZMC 12082).

Az ATMT során az Agrobacterium tumefaciens GV3101 törzsett alkalmaztuk, amely a pTiC58-ból származó (Koncz és Schell 1986) pMP90 helper plazmidot hordozza. A GV3101 törzs genomja rifampicin, míg a helper plazmid gentamicin rezisztencia gént hordoz. Bináris vektorként az S. F. Covert-től származó, általunk módosított, kanamycin rezisztenciát hordozó pPK2 vektort használtuk, melyet elektroporációval juttattunk a baktérium sejtekbe.

A plazmid klónozási munkákat Escherichia coli TOP10F- (Invitrogen) és XL1-Blue (Stratagene) törzsekkel végeztük.

\subsection{Alkalmazott táptalajok, tápoldatok és tenyésztési körülmények}

Minimál (YNB) tápoldat/táptalaj: $1 \%$ D-glükóz; $0,15 \% \quad\left(\mathrm{NH}_{4}\right)_{2} \mathrm{SO}_{4} ; 0,15 \%$ Na-Lglutaminát; $0,05 \%$ YNB; szükség esetén $0,05 \%$ uracillal vagy $0,05 \%$ leucinnal kiegészítve ( $\mathrm{pH} 4,5$ ). Szilárd táptalaj elöállításához 1,5\% agart adtunk a tápoldathoz.

PEG-közvetített protoplaszt transzformáció során a protoplasztokat $0,8 \mathrm{M}$ szorbitolt és $1 \%$ agart tartalmazó YNB fedőagarral összekeverve (pH 3,2) öntöttük 0,8 M szorbitollal kiegészített YNB táptalajra.

A karotintermelés vizsgálata során a YNB tápoldatot/táptalajt esetenként $20 \mathrm{mM} \mathrm{H}_{2} \mathrm{O}_{2}$-al, $1 \%$ pálmaolajjal vagy 1-1 $\mathrm{mM}$ nehézfémsóval $\left(\mathrm{FeSO}_{4}, \mathrm{CuSO}_{4}, \mathrm{CoCl}_{2}\right)$ egészítettük ki; a Dglükózt pedig a kísérlettől függően cellobiózzal, dihidroxi-acetonnal, etanollal, Dfruktózzal, D-galaktózzal, glicerinnel, glicerin-L-monoacetáttal, L-aszparaginsavval, Dmannózzal, maltózzal vagy trehalózzal helyettesítettük.

Malátás tápoldat/táptalaj $\quad$ (MEA): $1 \% \quad$ D-glükóz; $0,5 \%$ élesztőkivonat; $1 \%$ malátakivonat; szilárd táptalaj előállításához 1,5\% agar.

Élesztő - glükóz tápoldat/táptalaj (YEG): 1\% D-glükóz; 0,5\% élesztőkivonat; szilárd táptalaj előállításához 1,5\% agar.

Élesztő - pepton - glükóz tápoldat/táptalaj (YPG): 1\% D-glükóz; 1\% pepton; 0,5\% élesztőkivonat; szilárd táptalaj előállításához 1,5\% agar $(\mathrm{pH} 4,5)$. A protoplasztok regeneráltatása során $0,8 \mathrm{M}$ szorbitollal kiegészített YPG tápoldatot alkalmaztunk. 
Luria-Bertani tápoldat/táptalaj (LB): $1 \% \mathrm{NaCl} ; 1 \%$ tripton; 0,5\% élesztőkivonat; szilárd táptalaj előállításához $1,5 \%$ agar $(\mathrm{pH} 7,0)$. E. coli plazmidot hordozó törzsek szelekciójához $100 \mu \mathrm{g} / \mathrm{ml}$ ampicillinnel vagy $100 \mu \mathrm{g} / \mathrm{ml}$ kloramfenikollal az $A$. tumefaciens transzformáns törzsek szelekciójához $100 \mu \mathrm{g} / \mathrm{ml}$ rifampicinnel, $25 \mu \mathrm{g} / \mathrm{ml}$ gentamicinnel és $50 \mu \mathrm{g} / \mathrm{ml}$ kanamycinnel egészítettük ki a tápközeget.

SOC tápoldat: $0,05 \% \mathrm{NaCl} ; 2 \%$ tripton; $0,5 \%$ élesztőkivonat; $2,5 \mathrm{mM} \mathrm{KCl} ; 10 \mathrm{mM}$ $\mathrm{MgCl}_{2} ; 20$ mM D-glükóz (pH 7,0).

Indukciós tápoldat (IM): 1x MM sóoldat; 10 mM D-glükóz; 0,5\% glicerin; 40 mM MES; $200 \mu \mathrm{M}$ acetosziringon.

Indukciós táptalaj (IM): 1x MM sóoldat; $5 \mathrm{mM}$ D-glükóz; 0,5\% glicerin; $40 \mathrm{mM}$ MES; 1,5\% agar; $200 \mu \mathrm{M}$ acetosziringon.

$\mathrm{Az}$ indukciós táptalajt esetenként kiegészítettük 0,05\% leucinnal és 0,05\% uracillal is, hogy a gomba protoplasztok illetve spórák csírázásnak indulhassanak. A M. circinelloides transzformánsok szelekciójához $200 \mu \mathrm{M}$ cefotaximmal és leucinnal kiegészített YNB táptalajt alkalmaztunk.

Tenyésztési körülmények: A vad típusú gombatörzseket malátás vagy minimál, a transzformánsokat minimál táptalajon (szükség estén uracillal vagy leucinnal, az ATMTnél cefotaximmal is kiegészítve), kéthavonkénti átoltással, $4{ }^{\circ} \mathrm{C}$-on tartottuk fenn. Tenyésztésük általában $25^{\circ} \mathrm{C}$-on, négy napig, mesterséges vagy természetes fényforrással történő megvilágítás mellett történt. Esetenként a hőmérsékletet $\left(20-37{ }^{\circ} \mathrm{C}\right.$ között), a tenyésztési időt (1,5-4 nap), valamint a fényforrást a kísérleteknek megfelelően változtattuk. Későbbi felhasználás esetén a táptalajról vagy tápoldatból gyüjtött micéliumot (desztillált vizes mosás után) fagyasztva tároltuk. A baktérium törzsek tenyésztése a megfelelő antibiotikummal kiegészített LB tápoldatban/táptalajon történt, $E$. coli esetében $37^{\circ} \mathrm{C}$-on, az A. tumefaciens esetében pedig $28^{\circ} \mathrm{C}$-on. Felhasználásig a baktériumsejteket $-70{ }^{\circ} \mathrm{C}$-on tároltuk.

\subsection{Alkalmazott oldatok, pufferek és reagensek}

Kompetens E. coli sejtek készítéséhez és transzformációjához felhasznált oldatok $100 \mathrm{mM} \mathrm{CaCl}{ }_{2}$ oldat, hütve tárolva

$70 \%$ glicerin

TCM puffer: $10 \mathrm{mM}$ Tris (pH 7,5); $10 \mathrm{mM} \mathrm{CaCl}_{2} ; 10 \mathrm{mM} \mathrm{MgCl}_{2}$

Színszelekcióhoz: X-Gal (Fermentas): $20 \mathrm{mg} / \mathrm{ml}$ dimetilformamidban oldva és IPTG (Fermentas): $20 \mathrm{mg} / \mathrm{ml}$ steril desztillált vízben oldva 
Antibiotikum törzsoldatok: ampicillin (Sigma): $50 \mathrm{mg} / \mathrm{ml}$ törzsoldat steril desztillált vízben oldva; kloramfenikol (Egis): 50 mg/ml törzsoldat etanolban oldva (Brown 1991)

E. coli sejtekből történő plazmid DNS tisztításához használt oldatok

Sol1: 5 mM glükóz; 25 mM Tris-HCl (pH 8); 10 mM EDTA; 10 g/ml RNáz

Sol2: 0,2 M NaOH; $1 \%$ SDS

Nátrium-acetát puffer: $3 \mathrm{M}$ nátrium-acetát $75 \%$ jégecetben és $25 \%$ desztillált vízben oldva $(\mathrm{pH} 4,5)$

Plazmidtisztító kitek: Viogene Mini Plus ${ }^{\mathrm{TM}}$ Plasmid DNA Extraction System (Viogene), Viogene Midi Plus V100 ${ }^{\mathrm{TM}}$ Plasmid DNA Extraction System (Viogene)

Kompetens A. tumefaciens sejtek készítéséhez használt oldatok

$10 \%$ glicerin

\section{$\underline{\text { A. tumefaciens sejtekből történő plazmid DNS tisztításhoz használt anyagok }}$}

TE puffer: $10 \mathrm{mM}$ Tris (pH 8); 1 mM EDTA

$5 \mathrm{M} \mathrm{NaCl}$ oldat

10\% Nátrium-lauril-szarkozin oldat

Lizozim (Reanal): $20 \mathrm{mg} / \mathrm{ml}$ törzsoldat

Plazmid tisztító kit: Viogene Mini Plus ${ }^{\mathrm{TM}}$ Plasmid DNA Extraction System (Viogene)

Antibiotikum törzsoldatok: rifampicin (Fluka): $50 \mathrm{mg} / \mathrm{ml}$ törzsoldat DMSO-ban oldva; gentamicin (Sigma): $50 \mathrm{mg} / \mathrm{ml}$ törzsoldat steril desztillált vízben oldva; kanamycin (Egis):

$20 \mathrm{mg} / \mathrm{ml}$ törzsoldat steril desztillált vízben oldva (Brown 1991)

GombaDNS tisztításához használt anyagok

Lízis puffer: 50 mM Tris-HCl (pH 8,0); 20 mM EDTA; 1\% Nátrium-lauril-szarkozin RNáz (Sigma): $10 \mathrm{mg} / \mathrm{ml}$ törzsoldat $10 \mathrm{mM}$ Tris- $\mathrm{HCl}, 15 \mathrm{mM} \mathrm{NaCl}$ oldatban oldva PCI: fenol-kloroform-izoamilalkohol 25:24:1 arányú keveréke

CI: kloroform-izoamilalkohol 24:1 arányú keveréke

$\mathrm{CsCl}$ grádiens centrifugáláshoz: 47,75\% CsCl; $10 \mathrm{mg} / \mathrm{ml}$ bis-benzimid $(1,5 \%)$

DNS tisztító kit: DNeasy Plant Mini Kit (Qiagen)

Gomba RNS tisztításához használt anyagok

Lízis puffer: $30 \mathrm{mM}$ Nátrium-acetát $(\mathrm{pH} 5,2) ; 4 \mathrm{M}$ guanidin-izotiocianát, $1 \mathrm{M} \beta$ merkaptoetanol

CsCl oldat grádiens centrifugáláshoz: 5,7 M CsCl; 2 mM EDTA (pH 8,0)

DEPC kezelt desztillált víz 
CB: kloroform-butanol 4:1 arányú keveréke

3 M Nátrium-acetát oldat ( $\mathrm{pH} 5,2$ )

RNS tisztító kit: E.Z.N.A. ${ }^{\circledR}$ Fungal RNA Kit (Omega Bio-tek)

Gélelektroforézishez használt anyagok

TAE puffer: $40 \mathrm{mM}$ Tris-ecetsav ( $\mathrm{pH} 7,6) ; 1 \mathrm{mM} \mathrm{Na} \mathrm{N}_{2}$ EDTA

Agaróz gél: a fragmentum mérettől függően 0,7-2,5\% agaróz, TAE pufferben oldva

Etídium-bromid törzsoldat (Sigma): $10 \mathrm{mg} / \mathrm{ml}$ desztillált vízben oldva

Mintapuffer: 40\% szacharóz; 0,25 M brómfenolkék; 0,2 M EDTA; pH 8vagy 6x DNS mintapuffer (Fermentas) vagy 70\% glicerin, kísérlettől függően

Molekulasúly marker: 1 kb DNS létra (Fermentas); pUC Mix Marker (Fermentas); Lambda/HindIII Marker (Fermentas): steril desztillált víz - molekulasúly marker - 6x DNS mintapuffer 4:1:1 arányú keveréke

\section{$\underline{\text { ATMT során alkalmazott anyagok }}$}

2,5x MM sóoldat: 26,6 mM KH $\mathrm{KHO}_{4} ; 29,4 \mathrm{mM} \mathrm{K} \mathrm{K}_{2} \mathrm{HPO}_{4} ; 6,4 \mathrm{mM} \mathrm{NaCl} ; 5,1 \mathrm{mM}$ $\mathrm{MgSO}_{4} .7 \mathrm{H}_{2} \mathrm{O} ; 1,1 \mathrm{mM} \mathrm{CaCl} 2.2 \mathrm{H}_{2} \mathrm{O} ; 22,3 \mu \mathrm{M} \mathrm{FeSO}_{4} \cdot 7 \mathrm{H}_{2} \mathrm{O} ; 9,5 \mathrm{mM}\left(\mathrm{NH}_{4}\right)_{2} \mathrm{SO}_{4}$

1 M MES: 2-N-morfolin-etánszulfonsav törzsoldat, $\mathrm{pH}$ 5,3-ra állítva $5 \mathrm{M} \mathrm{KOH-dal}$ $25 \mathrm{mM}$ acetosziringon (Fluka): 3,5-dimetoxi-4-hidroxi-acetofenon törzsoldat desztillált vízben oldva, $\mathrm{pH}$ 8-ra állítva $5 \mathrm{M} \mathrm{KOH-dal}$

Cefotaxim (Merck): $50 \mathrm{mM}(23,8 \mathrm{mg} / \mathrm{ml})$ törzsoldat steril desztillált vízben oldva

\section{Protoplasztképzéshez és PEG-mediált transzformációhoz használt oldatok}

Protoplasztáló oldat: 100 mM Nátrium-foszfát puffer; $0,8 \mathrm{M}$ szorbitol; 1,5\% csigaenzim

Nátrium-foszfát puffer (100 mM): $25 \mathrm{mM} \mathrm{Na}_{2} \mathrm{HPO}_{4}, 75 \mathrm{mM} \mathrm{NaH}_{2} \mathrm{PO}_{4}$

SMC puffer: $50 \mathrm{mM} \mathrm{CaCl} 2 ; 10 \mathrm{mM}$ MOPS; 0,8 M szorbitol

PMC puffer: 40\% PEG 4000; 10 mM MOPS; 0,6 M szorbitol; $50 \mathrm{mM} \mathrm{CaCl}_{2}$

\section{Baktériumtelep és DNS blottoláshoz használt oldatok}

$10 \%$ SDS oldat

Depurináló oldat: $0,25 \mathrm{M} \mathrm{HCl}$ oldat

Denaturáló oldat: $0,5 \mathrm{M} \mathrm{NaOH} ; 1,5 \mathrm{M} \mathrm{NaCl}$

Neutralizáló oldat: $0,5 \mathrm{M}$ Tris; 1,5 M NaCl, pH 8

20x SSC: 3,0 M NaCl; 0,3 M Nátrium-citrát, pH 7. 


\section{RNS blottoláshoz használt oldatok és anyagok}

RNS futtató puffer denaturáló formaldehid gélelektroforézishez: 50\% deionizált formamid; 6,14\% formaldehid oldat; 1x MOPS puffer; 0,01\% brómfenolkék; 10\% glicerol MOPS puffer (10x): 0,4 M MOPS; 0,1 M Nátrium-acetát; 10 mM EDTA, pH 8,0 Deionizált formamid: 50 g ioncserélő AG501-X8 rezin (Bio-Rad); 500 ml formaldehid.

Hibridizációhoz használt oldatok és reagensek

Hibridizációs puffer: 5x SSC; 0,1\% Nátrium-lauril-szarkozin; 0,02\% SDS; $1 \%$ blokkoló reagens (Roche)

Hibridizációs puffer RNS mintákhoz: 7\% SDS; 50\% deionizált formamid; 5x SSC; $2 \%$ blokkoló reagens (Roche); $50 \mathrm{mM}$ Nátrium-foszfát (pH 7,0); 0,1\% Nátrium-laurilszarkozin

Mosó pufferek: 2x SSC; 0,1\% SDS

$$
0,1 \times \text { SSC; } 0,1 \% \text { SDS }
$$

1. detektáló puffer: 0,01 M maleinsav; 0,015 M NaCl, pH 7,5

2. detektáló puffer: 1\% blokkoló reagens (Roche) 1. detektáló pufferben

3. detektáló puffer: 0,1 M Tris-HCl; 0,1 M NaCl; $50 \mathrm{mM} \mathrm{MgCl}_{2}$, pH 9,5

Alkalikus foszfát antitest-konjugátum (Anti-Digoxigenin-AP Fab fragments, Roche)

Színreakciós előhíváshoz: NBT-BCIP törzsoldat (DIG DNA Labeling and Detection Kit, Roche): nitroblue tetrazolium-klorid és 5-bromo-4-kloro-3-indolilfoszfát toluidin só keveréke

Röntgen filmes előhíváshoz: CDP-Star kemilumineszcens szubsztrát (Roche): $25 \mathrm{mM}$ törzsoldat; előhívó oldat: GBX developer and replenisher (Kodak); fixáló oldat: GBX fixer and replenisher (Kodak), a gyártó utasításai szerint hígítva

\subsection{A kísérletek során alkalmazott primerek és DNS próbák}

Munkánk során primereket terveztünk a vizsgált gének felszaporítására, valamint a transzformánsok vizsgálatához, azaz a transzformáló DNS jelenlétének igazolására, DNS átrendeződések vizsgálatára, inverz-PCR-hoz az integráció helyének azonosítására, valamint valós idejü PCR-hoz a kópiaszám és a transzkripciós szintek meghatározásához (2. táblázat).

A hibridizációs kísérletekhez a PCR DIG Probe Synthesis Kit (Roche) segítségével készítettük a különböző génpróbákat ( $c r t Z, c r t W$, ipi, isoA, carG génpróbák), melyekhez a 2. táblázatban felsorolt primereket használtuk. 


\begin{tabular}{|c|c|c|c|c|}
\hline Primer & Szekvencia 5'- 3', & \multicolumn{2}{|c|}{ Felhasználás } & $\begin{array}{c}\text { Amplifikált } \\
\text { szakasz mérete } \\
\text { (bp) }\end{array}$ \\
\hline crtZ1 & ATG ACC AAT TTC CTG ATC & \multirow{2}{*}{\multicolumn{2}{|c|}{$\begin{array}{l}\text { Paracoccus sp. N81106 törzs crtZ } \\
\text { génjének amplifikálása }\end{array}$}} & \multirow{2}{*}{486} \\
\hline crtZ2 & CGT GCG CTC CTG CGC CTC & & & \\
\hline crtW1 & ATG AGC GCA CAT GCC CTG C & \multirow{2}{*}{\multicolumn{2}{|c|}{$\begin{array}{l}\text { Paracoccus sp. N81106 törzs } \\
\text { crtW génjének amplifikálása }\end{array}$}} & \multirow{2}{*}{726} \\
\hline crtW2 & TGC GGT GTC CCC CTT GGT G & & & \\
\hline ipi1 & $\begin{array}{c}\text { GGC TCG AGA TGG CCC CTG ATT TGA AGG } \\
\text { AAT A }\end{array}$ & \multirow{2}{*}{\multicolumn{2}{|c|}{$\begin{array}{l}\text { M. circinelloides ipi génjének } \\
\text { amplifikálása }\end{array}$}} & 929 (gDNS) \\
\hline ipi2 & $\begin{array}{c}\frac{\text { CTC GCG GCC GCT TAG AAG CCT AAA CGA }}{\text { TGA ATG GT }} \\
\text { ATA }\end{array}$ & & & 697 (cDNS) \\
\hline fpp1 & $\begin{array}{c}\text { GGC TCG AGA TGG TTG CTG TCA AAT TAC } \\
\text { A }\end{array}$ & \multirow{2}{*}{\multicolumn{2}{|c|}{$\begin{array}{l}\text { M. circinelloides isoA génjének } \\
\text { amplifikálása }\end{array}$}} & $1510(\mathrm{gDNS})$ \\
\hline fpp2 & $\begin{array}{c}\text { CTC GCG GCC GCT TAT TTA GTA CGC TTG } \\
\text { TAA A }\end{array}$ & & & $1078(\mathrm{cDNS})$ \\
\hline ggpp1 & $\begin{array}{l}\text { GGC TCG AGA TGC TCA ACT CAC ACA ACA } \\
\text { G }\end{array}$ & \multirow{2}{*}{\multicolumn{2}{|c|}{$\begin{array}{l}\text { M. circinelloides carG génjének } \\
\text { amplifikálása }\end{array}$}} & $1480(\mathrm{gDNS})$ \\
\hline ggpp2 & $\begin{array}{c}\text { CTC GCG GCC GCC TAG TCG TTG GTG GCC } \\
\text { TCT A }\end{array}$ & & & $931(\mathrm{cDNS})$ \\
\hline rib1 & $\begin{array}{l}\text { CTC GAG CTC CTG GTT GAT CCT GCT TGT } \\
\text { AGT CA }\end{array}$ & \multirow{2}{*}{\multicolumn{2}{|c|}{$\begin{array}{l}\text { M. circinelloides } 18 \mathrm{~S} \text { rDNS régió } \\
\text { amplifikálása }\end{array}$}} & \multirow{2}{*}{1829} \\
\hline rib2 & $\begin{array}{c}\text { CTC GGT ACC AAT GAT CCT TCC GCA GGT } \\
\text { TCA CCT }\end{array}$ & & & \\
\hline rib3 & $\begin{array}{c}\text { CTC GGA TCC TAA TCA ATA ATT TTG GCT } \\
\text { TGT CCA }\end{array}$ & \multirow{2}{*}{\multicolumn{2}{|c|}{$\begin{array}{c}\text { M. circinelloides 28S rDNS régió } \\
\text { amplifikálása }\end{array}$}} & \multirow{2}{*}{1501} \\
\hline rib5 & $\begin{array}{l}\text { AGA GTT TCC TCT GGC TTC ACC CTA TTC } \\
\text { A }\end{array}$ & & & \\
\hline gpdP & CAT GAA GTG TGA GAC ATT GCG A & \multirow{2}{*}{\multicolumn{2}{|c|}{$\begin{array}{c}\text { M. circinelloides gpdl promóter } \\
\text { és terminális régióira írt primerek, } \\
\text { kontroll PCR-hoz }\end{array}$}} & \multirow[t]{2}{*}{$\begin{array}{l}\text { 1321+a két régió } \\
\text { közé épített gén } \\
\text { mérete }\end{array}$} \\
\hline gpdT & TAC ATA TCA GAG GGT TGG AAC A & & & \\
\hline ipireal-time1 & ATG TGG ACC AAC ACT TGC TGC TC & \multirow{10}{*}{\multicolumn{2}{|c|}{$\begin{array}{c}\text { valós idejü PCR-hoz, a gén } \\
\text { kópiaszám és génkifejeződés } \\
\text { vizsgálatához }\end{array}$}} & \multirow{2}{*}{119} \\
\hline ipireal-time2 & TTG ATG CCA AGC TCA TGC TCC AG & & & \\
\hline isoAreal-time1 & ATC TCG ACT GTT ACG GTG CTC CT & & & \multirow{2}{*}{119} \\
\hline isoAreal-time2 & CTT GCG TTG TTC GGG ATT AGC CA & & & \\
\hline carGreal-time1 & CAA CAT CAT CAG CCA GAA GCC CA & & & \multirow{2}{*}{148} \\
\hline carGreal-time2 & ACC ACC CAA ACG CTT GAT TTC CT & & & \\
\hline crtWreal-time1 & CTT CAT CGG CAC CTA TTT CGG CT & & & \multirow{2}{*}{149} \\
\hline crtWreal-time2 & CGA ACA CGA ACA GCT GGA TCG AC & & & \\
\hline actreal-time1 & CAC TCC TTC ACT ACC ACC GCT GA & & & \multirow{2}{*}{117} \\
\hline actreal-time2 & GAG AGCA GAG GAT TGA GCA GCA G & & & \\
\hline leuAv8inv1 & CTG GTC ATG AAG TGC CCT TTG AGG T & \multirow{4}{*}{$\begin{array}{l}\text { MS12+pCA81f } \\
\text { transzformánsok }\end{array}$} & \multirow{12}{*}{$\begin{array}{c}\text { inverz- } \\
\text { PCR-hoz } \\
\text { az } \\
\text { integráció } \\
\text { helyének } \\
\text { meghatáro } \\
\text { zásához }\end{array}$} & \multirow{12}{*}{ nem ismert } \\
\hline leuAe8inv2 & CTC GCT CGT CTA CTA GCA GGT TGT & & & \\
\hline gpdPe8inv3 & GGC TGC GCG TGG TTC ACA CTA AT & & & \\
\hline arsMe8inv4 & GTT TGG CTG TGC TCA TCG CAC T & & & \\
\hline 18S9inv1 & GTA ATT TGC ACG CCT GCT GCC T & \multirow{2}{*}{$\begin{array}{l}\text { MS12+pCA91f } \\
\text { transzformánsok }\end{array}$} & & \\
\hline 28S9inv2 & CCG TCT TGA AAC ACG GAC CAA GGA & & & \\
\hline pl51inv1 & CAA CAG CGG TAA GAT CCT TGA GAG T & \multirow{2}{*}{$\begin{array}{l}\text { MS12+pPT51R } \\
\text { transzformánsok }\end{array}$} & & \\
\hline pl51inv2 & GGG CTA GAC TGC TCT CCA AAT GCA & & & \\
\hline pl8remiinv2 & CAC TTT ATG CTT CCG GCT CGT ATG T & \multirow{2}{*}{$\begin{array}{l}\text { MS12+pCA8R } \\
\text { transzformánsok }\end{array}$} & & \\
\hline gpdTv8remiinv1 & GCT GTT ACT GTT ACT ATC GCC CT & & & \\
\hline gpdTv8remiinv1 & GCT GTT ACT GTT ACT ATC GCC CT & MS12+pPK2W & & \\
\hline pyrGvA-51inv2 & CTT GAA AGA GTG CGT CTC CAC AAG A & transzformánsok & & \\
\hline amprev1 & GGC GAC ACG GAA ATG TTG AAT AC & plazmid mene & során & \\
\hline amprev2 & CGA AAT AGA CAG ATC GCT GAG & szekvenált & & - \\
\hline
\end{tabular}

2. táblázat. Kísérleteink során felhasznált primerek, szekvenciájuk és felhasználásuk. Amennyiben az indítószekvencia 5 ' végén restrikciós hasítóhelyet tartalmaz, azt minden esetben aláhúzott nukleotidok jelölik, egyben feltüntetve a restrikciós enzimek müködéséhez szükséges további nukleotidokat is. 


\subsection{A kísérletek során felhasznált expressziós vektorok}

Munkánk során homológ és heterológ géneket hordozó transzformációs vektorokat szerkesztettünk. Ezek a M. circinelloides IPP izomerázt kódoló ipi, FPP szintázt kódoló isoA, GGPP szintázt kódoló carG és fitoén szintázt/likopin ciklázt kódoló carRP, valamint Paracoccus sp. N81106 törzs $\beta$-karotin hidroxilázt kódoló crtZ és $\beta$-karotin ketolázt kódoló $c r t W$ génjeit hordozó vektorok.

A három izoprén bioszintézis útban résztvevő gént saját szabályozó régióival együtt klónoztuk plazmidokba, ugyanakkor a bakteriális eredetü génekhez hasonlóan gpdl (glicerinaldehid-3-foszfát dehidrogenáz gén, EMBL azonosító: AJ293012) promóter és terminális $(g p d l P$ és $g p d 1 T)$ régióinak szabályozása alá is helyeztük (így biztosítottuk a heterológ gének expresszióját), annak érdekében, hogy az összes gént azonos szabályozás alatt tudjuk vizsgálni. Minden esetben a pPT43 (Papp és mtsi. 2006) plazmidot használtuk a vektorok építéséhez, amely hordozza a gpdl promóter és terminális régióit pBluescript SK+ klónozó vektorba (Stratagene) építve.

A transzformánsoknak hordozniuk kell egy (vagy több) szelekciót biztosító gént. Rendelkezésünkre állt egy leucin és uracil auxotrófiával markerezett $M$. circionelloides mutáns törzs (MS12), illetve az ezen auxotrófiákat komplementáló gének és az azokat hordozó plazmidok: az $\alpha$-izopropilmalát izomerázt kódoló leuA gén (Roncero és mtsi. 1989) pBluescript SK+ klónozó vektorba építve (pAVB107, Velayos 2000) és az orotidin5 '-monofoszfát dekarboxilázt kódoló pyrG gén (Benito és mtsi. 1992) pBluescript SK+ vektorba építve (pEPM9 illetve pEPM901, Benito és mtsi. 1992).

\section{A $\beta$-karotintermelés fokozásához épített autonóm replikálódó vektorok}

$\checkmark$ pAVB160 plazmid a rendelkezésünkre állt, amely a $M$. circinelloides isoA gént hordozza leuA szelekciós marker génnel (Velayos 2000)

$\checkmark$ pAVB161 plazmid a rendelkezésünkre állt, amely a $M$. circinelloides carG gént hordozza leuA szelekciós marker génnel (Velayos 2000)

$\checkmark$ pCA10 plazmid a $M$. circinelloides ipi gént hordozza pyrG szelekciós marker génnel. Előzőleg az ipi cDNS-ét pBluescript SK+ klónozó vektorba építettük (pZ4)

$\checkmark$ pCA6 plazmid a $M$. circinelloides car $G$ gént hordozza pyr $G$ szelekciós génnel

$\checkmark$ pPT82 plazmid a gpdP-ipi-gpdT expressziós kazettát hordozza pyrG szelekciós génnel

$\checkmark$ pPT83 plazmid a gpdP-isoA-gpdT expressziós kazettát hordozza pyrG szelekciós génnel 
$\checkmark$ pPT84 plazmid a gpdP-carG-gpdT expressziós kazettát hordozza $p y r G$ szelekciós génnel

$\checkmark$ pPT85 plazmid a gpdP-ipi-gpdT expressziós kazettát hordozza leuA szelekciós génnel

$\checkmark$ pPT86 plazmid a gpdP-isoA-gpdT expressziós kazettát hordozza leuA szelekciós génnel.

$\underline{\text { Xantofillok termeltetéséhez épített autonóm replikálódó vektorok }}$

$\checkmark$ pPT50 plazmid a Paracoccus sp. N81106 törzs crtZ génjét hordozza Mucor gpd1P és gpdlT régiói között pyrG marker génnel

$\checkmark$ pPT51 plazmid a Paracoccus sp. N81106 törzs crtW génjét hordozza Mucor gpd1P és gpdlT régiói között leuA marker génnel

$\checkmark$ pPT72 plazmid egy carRP-crtW fúziós gént hordozó vektor, carRP promóter szabályozása alatt pyrG szelekciós génnel.

$\checkmark$ A pPT75 vektort a carRP gén deléciójához készítettük, ahol a leuA gént az elrontani kívánt génbe építettük.

$\underline{\text { Xantofillok termeltetéséhez épített, integrációt eredményező vektorok }}$

$\checkmark$ pCA8 plazmid a gpdlP-crtW-gpdlT expressziós kazettát hordozza a kettős homológ rekombinációt irányító leuA és a leuA 5' vég melletti szekvenciával összeépítve. A plazmidból kivágott lineáris fragmentummal transzformáltunk.

$\checkmark$ pCA9 plazmid a gpd1P-crtW-gpd1T expressziós kazettát hordozza a kettős homológ rekombinációt irányító $18 \mathrm{~S} r D N S$ és a $28 \mathrm{~S} r D N S$ régiók között, pyrG szelekciós génnel. A plazmidból kivágott lineáris fragmentummal transzformáltunk.

$\checkmark$ pPK2-crtW plazmid egy bináris vektor ATMT-hez, amely a gpd1P-crtW-gpd1T expressziós kazettát hordozza pyrG szelekciós génnel.

\subsection{Vizsgálati módszerek}

\subsubsection{DNS tisztítása Mucor circinelloides-ből}

A DNS tisztításához a micéliumot folyékony nitrogénben tártuk fel. A feltárás után a micéliumhoz grammonként 2,5 ml lízis puffert adtunk és üvegbottal a teljes homogenitás eléréséig kevergettük. RNáz-t adtunk a homogenizátumhoz (20 $\mu \mathrm{g} / \mathrm{ml}$ koncentrációban), majd a lízis elősegítéséhez 20-30 percig $65{ }^{\circ} \mathrm{C}$-on inkubáltuk (közben időnként megkeverve), majd szobahőmérsékletüre történő hütés után centrifugáltuk (8000 g, 10 perc, $4{ }^{\circ} \mathrm{C}$ ). A felülúszóhoz azonos mennyiségü PCI-t adtunk, majd $4{ }^{\circ} \mathrm{C}$-on, 2-3 órán 
keresztül, a fázisok elkeveredéséig enyhén kevertettük (45 rpm). Centrifugálás után (8000 $\mathrm{g}, 15$ perc, $4{ }^{\circ} \mathrm{C}$ ) a vizes fázist azonos mennyiségü CI-vel mostuk. Újabb centrifugálást (8000 g, 15 perc, $4{ }^{\circ} \mathrm{C}$ ) követően a vizes fázist kétszeres mennyiségü 96\%-os etanollal kicsaptuk (2 óra $-20{ }^{\circ} \mathrm{C}$-on vagy 30 perc $-70{ }^{\circ} \mathrm{C}$-on), majd centrifugálással ülepítettük a DNS-t (13000 g, 20 perc, $\left.4{ }^{\circ} \mathrm{C}\right)$. A csapadékot vákuum alatt beszárítottuk, majd $500 \mu 1$ steril desztillált vízbe visszaoldottuk. A vizes fázist esetenként $\mathrm{CsCl}$ grádiens centrifugálással (44000 rpm, 40 óra $20{ }^{\circ} \mathrm{C}, 70.1 \mathrm{Ti}$ rotor/ Beckman C8-70M) tovább tisztítottuk (Iturriaga és mtsi. 1992).

Gyakran a tisztítást a DNeasy Plant Mini Kit (Qiagen) segítségével végeztük, a gyártó utasításai szerint.

\subsubsection{RNS tisztítása M. circinelloides-ből}

Az RNS tisztítást általában az E.Z.N.A. Fungal RNA Kit (Omega Bio-tek) segítségével, a gyártó utasításai szerint végeztük. Néhány esetben Choi és mtsi. (1988) leírását követtük: folyékony nitrogénnel feltártuk a micéliumot, majd a mintákat grammonként $3 \mathrm{ml}$ lízis pufferrel vortexeltük, ezután $4{ }^{\circ} \mathrm{C}$-on inkubáltuk 5-24 órán keresztül. Centrifugálás ( $8000 \mathrm{~g}, 3$ óra, $\left.4{ }^{\circ} \mathrm{C}\right)$ után a felülúszót $\mathrm{CsCl}$ oldatra rétegeztük ( $\mathrm{kb}$. $9 \mathrm{ml}$ felülúszót lehet 3,5 $\mathrm{ml} \mathrm{CsCl}$ oldatra felvinni). A mintákat ultracentrifugában (SW40 rotor, Beckman) $25000 \mathrm{rpm}-\mathrm{mel}, 12-18$ órán át $20{ }^{\circ} \mathrm{C}$-on centrifugáltuk. A felülúszót leöntése után a kiülepedett RNS mintákat $200 \mu$ DEPC kezelt desztillált vízzel átmostuk, majd $400 \mu \mathrm{l}$ DEPC kezelt desztillált vízben felszuszpendáltuk. Ezután a mintákat 3-4 alkalommal CB-vel extraháltuk (közben centrifugálás: 1-2 perc, 3000 g). Az RNS kivonatot új csőbe vittük át és $2,2 x$ mennyiségü etanollal valamint 0,1 térfogat Nátriumacetáttal kicsaptuk és felhasználásig $-70^{\circ} \mathrm{C}$-on tároltuk.

\subsubsection{DNS/RNS gélelektroforézis}

A nukleinsav mintákhoz mintapuffert adtunk, majd a várt fragmentumok és a gél méretétől, illetve a kísérlettől függően 0,7 - 2,5\% agarózgélben, 80 - 110 V feszültséggel, 1-4 órán keresztül végeztük az elválasztást. Mind az agarózgél elkészítéséhez, mind futtatópuffernek TAE puffert használtunk. A nukleinsavakat etidíum-bromidos festéssel $(0,5 \mu \mathrm{g} / \mathrm{ml})$, UV fény alatt detektáltuk. A fragmentum méretének meghatározásához különböző molekulasúly markereket használtunk. 


\subsubsection{DNS izolálása agaróz gélből}

A visszaizolálni kívánt DNS fragmentumokat tartalmazó gél részletet steril szikével UV lámpa alatt vágtuk ki a 0,7\% agarózt tartalmazó gélből. A DNS-t a DNA Extraction Kit (Fermentas) vagy a Gel-M Gel Extraction System (Viogene) kit segítségével nyertük ki a gyártó utasításainak megfelelően.

\subsubsection{Alkalmazott PCR technikák és reakciókörülmények}

Munkánk során különböző PCR technikákat alkalmaztunk. Az amplifikálást T3 Thermocycler (Biometra), valamint MJ Mini (Bio-Rad) készülékekkel végeztük. Real-time PCR esetében iCycler Thermal Cycler-t iQ5 Real-Time System, valamint C1000 Thermal Cycler-t CFX96 Real-Time System detektáló rendszerekkel alkalmaztunk.

Génklónozáshoz, vektorok építéséhez, ellenőrzéshez, valamint a transzformánsok vizsgálatai során alkalmazott reakciókörülmények

A reakciókat Dupla-Taq (ZenonBio), Expand High Fidelity PCR System (Roche), Pfu (Fermentas) vagy Long-PCR Enzyme Mix (Fermentas) kitek segítségével mértük össze $50 \mu 1$ végtérfogatban a következők szerint:

20-50 ng genomi vagy plazmid DNS

$0,4 \mu \mathrm{M}-0,4 \mu \mathrm{M}$ specifikus primer

0,4 mM dNTP mix (Fermentas)

1x Dupla-Taq puffer

2,5 $\mathrm{mM} \mathrm{MgCl}_{2}$

2 U Dupla-Taq DNS polimeráz

20-50 ng genomi vagy plazmid DNS

$0,4 \mu \mathrm{M}-0,4 \mu \mathrm{M}$ specifikus primer

0,4 mM dNTP mix (Fermentas)

1x $P f u$ puffer

$2,5 \mathrm{mM} \mathrm{MgSO}_{4}$

1,25 U Pfu DNS polimeráz
20-50 ng genomi vagy plazmid DNS

$0,8 \mu \mathrm{M}-0,8 \mu \mathrm{M}$ specifikus primer

0,2 mM dNTP mix (Fermentas)

1x Expand High Fidelity puffer (1,5

$\mathrm{mM} \mathrm{MgCl} 2$-dal kiegészítve)

2,6 U Expand High Fidelity enzim

20-50 ng genomi vagy plazmid DNS

$0,4 \mu \mathrm{M}-0,4 \mu \mathrm{M}$ specifikus primer

$0,4 \mathrm{mM}$ dNTP mix (Fermentas)

1x Long PCR puffer (1,5

$\mathrm{mM} \mathrm{MgCl} 2$-dal kiegészítve)

1,25 U Long PCR Enzyme Mix

\begin{tabular}{|c|c|c|}
\hline $95^{\circ} \mathrm{C}$ & 3 perc & 1 ciklus \\
\hline $95^{\circ} \mathrm{C}$ & 1 perc & \\
\hline $55-68^{\circ} \mathrm{C}$ & 1 perc & 35 ciklus \\
\hline $72^{\circ} \mathrm{C}$ & $2-5$ perc & \\
\hline $72^{\circ} \mathrm{C}$ & 10 perc & 1 ciklus \\
\hline
\end{tabular}

kezdeti denaturáció

denaturáció

primer kötődés

láncszintézis

végső láncszintézis 
$\underline{\text { A } M \text {. circinelloides ipi gén határoló (downstream és upstream) régióinak meghatározása }}$

A M. circinelloides ipi génjét a spanyol kutatócsoporttal együttmüködve azonosítottuk, klónoztuk és meghatároztuk a határoló szekvenciáit (Csernetics és mtsi. 2011a). A gént határoló downstream és upstream régiók meghatározása GenomeWalker Universal Kit (Clontech) segítségével történt. PvuII, ScaI, SmaI and StuI emésztett genomi DNS fragmentumokból, a Genome Walker Adaptor-ral történő ligálás után mértük össze a PCR reakciókat, Hot-start PCR, Advantage 2 PCR Enzyme System (Clontech) segítségével, a gyártó utasításai szerint.

\section{Elsődleges PCR reakció}

$1 \mu 1$ DNS könyvtár

1x Advantage 2 PCR puffer

$0,2 \mathrm{mM}$ dNTP Mix

$0,2 \mu \mathrm{M}$ adaptor primer 1 (AP1)

$0,2 \mu \mathrm{M}$ génspecifikus primer1 (GSP1)

1x Advantage 2 PCR Mix

$94{ }^{\circ} \mathrm{C} 25$ másodperc $\}$

$72{ }^{\circ} \mathrm{C} 3$ perc $\} 7$ ciklus

$94{ }^{\circ} \mathrm{C} 25$ másodperc

$67^{\circ} \mathrm{C} 3$ perc 35 ciklus
Másodlagos PRC reakció

$1 \mu 1$ elsődleges PCR termék

1x Advantage 2 PCR puffer

$0,2 \mathrm{mM}$ dNTP Mix

$0,2 \mu \mathrm{M}$ adaptor primer2 (AP2)

$0,2 \mu \mathrm{M}$ génspecifikus primer2 (GSP2)

1x Advantage 2 PCR Mix

$67{ }^{\circ} \mathrm{C} 7$ perc $\quad 1$ ciklus

A klónozott 2058 bp hosszú fragmentumokat pBluescript SK+ vektorba ligáltuk.

A génróbák készítése során alkalmazott reakciókörülmények

A reakciókat a PCR DIG Probe Synthesis Kit (Roche) segítségével állítottuk össze $50 \mu 1$ végtérfogatban a következők szerint:

20-50 ng plazmid vagy genomi DNS

$1 \mu \mathrm{M}-1 \mu \mathrm{M}$ specifikus primer

$0,1 \mathrm{mM}$ dNTP mix (Fermentas)

0,1 mM PCR DIG mix (DIG-11-dUTP-t tartalmaz)

1x Expand High Fidelity puffer (1,5 $\mathrm{mM} \mathrm{MgCl} \mathrm{M}_{2}$-dal kiegészítve)

2,6 U Expand High Fidelity enzim

$\left.\begin{array}{ll}95{ }^{\circ} \mathrm{C} & \begin{array}{l}3 \text { perc } \\ 95{ }^{\circ} \mathrm{C}\end{array} \\ 58-68{ }^{\circ} \mathrm{C} & \begin{array}{l}1 \text { perc } \\ 1 \text { perc } \\ 72{ }^{\circ} \mathrm{C}\end{array} \\ 72-5 \text { perc } \\ 7{ }^{\circ} \mathrm{C} & \begin{array}{l}1 \text { ciklus } \\ 10 \text { perc }\end{array}\end{array}\right\} \begin{aligned} & \begin{array}{l}\text { kezdeti denaturáció } \\ \text { denaturáció } \\ 35 \text { ciklus }\end{array} \\ & \begin{array}{l}\text { primer kötődés } \\ \text { láncszintézis } \\ \text { végső láncszintézis }\end{array}\end{aligned}$

$4{ }^{\circ} \mathrm{C}$-ra hütés 


\section{Inverz-PCR reakciók az integráció helyének meghatározásához}

A transzformánsokból tisztított DNS-t különböző restrikciós enzimekkel emésztettük (transzformánsoktól függően SalI, ScaI, BstXI, ClaI, SmaI és/vagy NheI enzimeket használtunk). Egy éjszakán át végzett emésztés után a mintákat 96\% etanollal kicsaptuk ( 2 óra, $-20{ }^{\circ} \mathrm{C}$ ), majd centrifugálás (16000 g, 20 perc) után 70\%-os etanollal mostuk. Az újabb centrifugálással (16000 g, 5 perc) ülepített DNS-t vákuum alatt szárítottuk. A DNS-t ezután $10 \mu \mathrm{l}$ steril desztillált vízbe visszaoldottuk, majd a fragmentumokat önmagukkal ligáltuk $\left(8^{\circ} \mathrm{C}, 16\right.$ óra). A ligátumokat ezután ismét $96 \%$ etanollal kicsaptuk, centrifugálás (16000 g, 20 perc) után mostuk 70\% etanollal, majd újbóli ülepítés (16000 g, 5 perc) után felszuszpendáltuk steril desztillált vízben. Az így nyert DNS mintákból mértük össze a PCR reakciókat Pfu polimerázzal (ZenonBio) $25 \mu 1$ végtérfogatban a következők szerint:

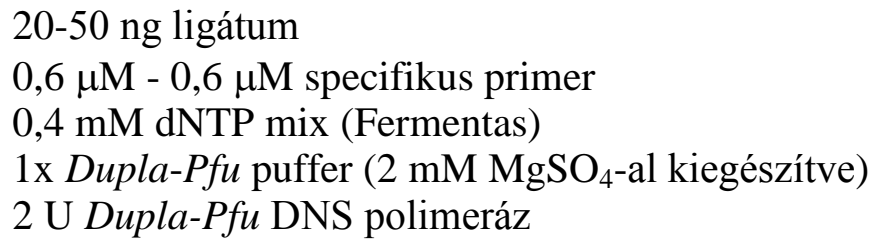

Valós idejü PCR reakciók a kópiaszám, valamint a transzkripciós szintek meghatározásához

A méréseket monosporangiális telepekből izolált DNS-ből illetve RNS-ből végeztük. Az egylépéses reakciókat iQ SYBR Green Supermix (Bio-Rad) segítségével mértük össze. A nyert eredményeket a $2^{-\Delta \Delta \mathrm{Ct}}$ módszer segítségével értékeltük ki (Livak and Schmittgen 2001).

A reakciók összemérése $20 \mu$ l végtérfogatban történt 96 lyukú lemezeken:

$$
\begin{aligned}
& \text { 20-50 ng DNS vagy cDNS } \\
& 0,4 \mu \mathrm{M}-0,4 \mu \mathrm{M} \text { specifikus primer } \\
& \text { 1x iQ SYBR Green Supermix }
\end{aligned}
$$

\begin{tabular}{|c|c|c|c|}
\hline $95^{\circ} \mathrm{C}$ & 3 perc & 1 ciklus & kezdeti denaturáció \\
\hline $95^{\circ} \mathrm{C}$ & 1 perc & & denaturáció \\
\hline $69^{\circ} \mathrm{C}$ & 30 másodperc & 40 ciklus & primerkötődés és láncszintéz \\
\hline
\end{tabular}

Melting curve analízis:

$\begin{array}{lll}95{ }^{\circ} \mathrm{C} & 3 \text { perc } & 1 \text { ciklus } \\ 65{ }^{\circ} \mathrm{C} & 2 \text { perc } & 1 \text { ciklus } \\ 55^{\circ} \mathrm{C}-95^{\circ} \mathrm{C} & 10 \text { másodperc } & 0,5^{\circ} \mathrm{C} \text {-onként emelkedő hőmérséklet }\end{array}$




\subsubsection{Génklónozás során alkalmazott módszerek, plazmid konstrukciók létrehozása}

Restrikciós emésztések, ligálás, plazmidok építése és plazmid DNS tisztítása

A restrikciós emésztéseket, ligálásokat a standard módszerek szerint végeztük (Sambrook és mtsi. 1989) követve a gyártó utasításait, valamint optimalizálva az adott kísérleti körülményekhez. A DNS fragmentumokat pBluescript SK+ (Stratagene) vagy a pUC18 (Fermentas) klónozó vektorokba T4 DNS ligázzal (Fermentas) építettük $8{ }^{\circ} \mathrm{C}$-on, 16 órán keresztül. Esetenként az InsT/Aclone PCR Product Cloning Kit-ben (Fermentas) található pTZ57 R/T vektort is használtuk. A PCR során nyert fragmentumok tisztításához a PCR-M Clean Up System (Viogene) kitet használtuk.

Plazmid DNS tisztításához a Viogene Mini-M Plasmid DNA Extraction System (Viogene), nagyobb mennyiségü plazmid DNS tisztításához a Viogene Midi-V100 Plasmid DNA Extraction System (Viogene) kiteket használtuk a gyártó utasításai szerint. Nagyobb mintaszám esetében a plazmid tisztítást általunk készített oldatokkal végeztük a következők szerint: $3 \mathrm{ml}$, ampicillinnel vagy kloramfenikollal kiegészített LB tápoldatban nevelt $E$. coli sejteket centrifugálással összegyüjtöttünk (16000 g, 2 perc). A sejteket 150 $\mu 1$ Sol1 oldattal lizáltuk. 5 perc szobahőmérsékleten történő inkubáció után $200 \mu 1$ Sol2 oldatot adtunk a lizátumhoz, majd enyhe összekeverés után a mintákat jégen inkubáltuk 5 percig. Ezután $150 \mu 1$ Nátrium-acetátot adtunk a mintákhoz, majd 10 perc jégen történő inkubáció után az így kisózott DNS-t centrifugáltuk (16000 g, 10 perc). A felülúszót 96\% etanollal kicsaptuk ( 2 óra, $-20{ }^{\circ} \mathrm{C}$ ), majd centrifugálás (16000 g, 20 perc) és $70 \%$ etanollal történő mosás után a DNS-t $50 \mu 1$ steril desztillált vízbe visszaoldottuk.

A. tumefaciens sejtekből a plazmid DNS tisztítását kiegészítettük néhány, az extracelluláris poliszacharidok eltávolítását elősegítő lépéssel. A rifampicinnel, gentamicinnel és kanamycinnel kiegészített, $10 \mathrm{ml}$ LB tápoldatban nevelt sejteket centrifugálással (2160 g, 3 perc) ülepítettük, majd a tápoldat eltávolítása után a sejteket 1 ml TE pufferben szuszpendáltuk. A mintákhoz $100 \mu \mathrm{l} 5 \mathrm{M} \mathrm{NaCl}$ oldatot adtunk, erős vortexelés után $10 \mu 1$ 10\% Nátrium-lauril-szarkozinnal is kiegészítettük. Enyhe keverés után a sejteket ülepítettük (16000 g, 3 perc), majd a korábban leírtak szerint folytattuk a plazmid DNS tisztítást, azzal a különbséggel, hogy a lízis pufferrel felszuszpendált sejtekhez $20 \mu \mathrm{l}$ lizozim $(20 \mathrm{mg} / \mathrm{ml})$ oldatot adtunk, amit 15 percig $37^{\circ} \mathrm{C}$-on inkubáltunk, ezzel elősegítve a baktérium sejtek feltárását. 


\title{
cDNS szintézis (reverz transzkripció)
}

Az RNS mintákat DNáz (Fermentas) kezeltük, a gyártó utasításai szerint:

$1 \mu \mathrm{g}$ RNS

1x reakciópuffer $\left(2,5 \mathrm{mM} \mathrm{MgCl}_{2}\right.$-dal)

1 U RNáz inhibítor (Fermentas)

1 U DNáz

A reakciót 30 percig $37^{\circ} \mathrm{C}$-on végeztük, majd $5 \mathrm{mM}$ EDTA-val $65{ }^{\circ} \mathrm{C}$-on történő 10 perces kezeléssel állítottuk le. Minden minta esetében PCR illetve qPCR reakciók segítségével ellenőriztük a minták DNS mentességét.

A DNáz kezelt RNS mintákból a reverz transzkripciót RevertAid ${ }^{\mathrm{TM}} \mathrm{H}$ Minus First Strand cDNA Synthesis Kit (Fermentas) segítségével végeztük:

0,1-100 $\mu \mathrm{g}$ RNS izolátum

$5 \mu \mathrm{M}$ oligo $(\mathrm{dT})_{18}$ vagy random hexamer primer

$65{ }^{\circ} \mathrm{C}$-on 5 percig kezeltük, majd $4{ }^{\circ} \mathrm{C}$-on hütöttük. A további reakciókomponenseket is hozzáadtuk:

\author{
1x reakciópuffer $\left(2 \mathrm{mM} \mathrm{MgCl}_{2}\right.$-dal) \\ 20 U RNáz inhibítor \\ $1 \mathrm{mM}$ dNTP mix \\ 200 U RevertAid ${ }^{\mathrm{TM}}$ H Minus M-MULV Reverse Transcriptase enzim
}

A reakcióelegyet random hexamer primer esetén $25{ }^{\circ} \mathrm{C}$-on kezeltük 5 percig. A továbbiakban minden esetben $42{ }^{\circ} \mathrm{C}$-on 60 percig tartó inkubációt követően $70{ }^{\circ} \mathrm{C}$-on 5 percig tartó kezeléssel állítottuk le a reakciót.

\subsubsection{Szekvenciák meghatározása és elemzése}

Az általunk klónozott és vizsgált DNS fragmentumok, szerkesztett plazmidok szekvenálását az MTA Szegedi Biológiai Központjában (ABI 373 típusú automata szekvenátor, Applied Biosystem) illetve Berlinben az Agowa cégnél (3730xl és 3700 automata szekvenátor, Applied Biosystem) végeztettük. A DNS szekvenciák ellenőrzése a Chromas program segítségével történt, míg a nukleotid szekvenciák analízisét az NCBI BLAST 2 programjának segítségével végeztük (http://blast.ncbi.nlm.nih.gov/Blast.cgi). A svájci „Expasy” szervert (http://www.expasy.ch) is használtuk a szekvenciák elemzése során. A fehérjeszekvenciák illesztését ClustalW program segítségével végeztük (www.ebi.ac.uk/clustalw). Az azonosított szekvenciákat az EMBL nukleotid szekvencia adatbázisba küldtük. 


\subsubsection{Baktérium telep/DNS blottolás és hibridizálás}

\section{Baktérium telepek blottolása}

$\mathrm{Az}$ ampicillint tartalmazó LB táptalajon nőtt baktérium telepeket hordozó Petricsészéket 2 órára $4{ }^{\circ} \mathrm{C}$-ra raktuk. Ezt követően a felszínükre hibridizációs membránt (Hybond-N+, Fluka) helyeztünk (5 perc). A membránt 2 percig 10\% SDS oldattal átitatott Whatman papírra helyeztük. Ezt követte a denaturáló oldattal (2 perc), majd neutralizáló oldattal (5 perc) történő Whatman szürőpapíros kezelés. Végül 30 másodpercig 2x SSC-vel átitatott szürőpapírra helyeztük a membránt, melyet ezután szobahőmérsékleten megszárítottunk és 1 percig UV fénnyel kezeltünk (DNS rögzítése).

\section{$\underline{\text { DNS blottolása }}$}

Agaróz gélelektroforézist követően a gélt esetenként depurináló oldatban 20 percig kezeltük, majd desztillált vizes öblítést követően denaturáló oldatba helyeztük. 30 perces denaturáló kezelést követően a gélt 30 percre neutralizáló oldatba tettük. Az így előkezelt gélt 16 órán keresztül 20x SSC oldat segítségével blottoltuk a hibridizációs membránra (Hybond-N+, Fluka), majd a DNS-t UV fény (2-3 perc) segítségével rögzítettük.

\section{Hibridizálás}

A hibridizációs membránt legalább két órán át $65-68{ }^{\circ} \mathrm{C}$-on hibridizációs pufferrel előhibridizáltuk, majd 16 órán át $65-68{ }^{\circ} \mathrm{C}$-on, jelölt próbát tartalmazó hibridizációs oldattal $(20 \mathrm{ng} / \mathrm{ml})$ hibridizáltunk. A próba jelöléséhez minden esetben digoxigenines jelölést alkalmaztuk (PCR DIG Probe Synthesis Kit, Roche). A jelölt próbát használat előtt minden esetben 10 perc $100{ }^{\circ} \mathrm{C}$-os, majd 10 perc $4{ }^{\circ} \mathrm{C}$-os inkubációval denaturáltuk.

A hibridizációs membránt szobahőmérsékleten 2 x 5 percig 2x SSC, 0,1\% SDS oldattal, majd kétszer 15 percig 65-68 ${ }^{\circ} \mathrm{C}$-on 0,1x SSC, 0,1\% SDS oldattal mostuk. Ezt követően az 1. detektáló pufferrel 1 percig, majd a 2. detektáló pufferrel 30 percig, majd a 2. detektáló pufferhez adott 1-4 $\mu 1$ alkalikus foszfát antitest-konjugátummal (AntiDigoxygenin-AP, Roche) újabb 30 percig inkubáltuk szobahőmérsékleten. Az antitestkonjugátum mennyiségét a detektálás módja határozta meg: kemilumineszcens festés esetén $1 \mu \mathrm{l}$, NBT-BCIP festés esetén $4 \mu \mathrm{l}$-t használtunk. Ezt követte kétszer 15 perces mosás 1. detektáló pufferrel, majd egy 2-5 perces mosás 3. detektáló pufferrel. A detektálást a 3. detektáló pufferhez adott $200 \mu$ NBT-BCIP (DIG DNA Labeling and Detection Kit, Roche) előhívó reagenssel végeztük sötétben történő inkubációval, 1-12 órán keresztül. Végül a felesleges festéket desztillált vízzel lemostuk. CDP-Star kemilumineszcens reagenssel (Roche) történő előhívást is alkalmaztunk: a 3. detektáló 
pufferhez $10 \mu \mathrm{l}$ kemilumineszcens szubsztrátot adtunk. Sötétszobában a hibridizációs filtert kazettába tettük, röntgenfilmet (Kodak) helyeztünk rá és néhány percig inkubáltuk. Az előhívást és a fixálást (2-2 perc) gyári oldatokkal (Kodak) végeztük.

\subsubsection{Northern hibridizálás}

A Northern hibridizálás során Sambrook és mtsi. (1989) leírását követtük. A felületek és a futtatókádak $10 \% \mathrm{H}_{2} \mathrm{O}_{2}$-al történő RNáz-mentesítése után az RNS mintákat denaturáló formaldehid-agaróz gélelektroforézissel elválasztottuk. A mintákat 96\% etanolban kicsaptuk (2 óra, $-70{ }^{\circ} \mathrm{C}$ ), majd centrifugálás (16000 g, 20 perc) után $70 \%$ etanollal mostuk. Újabb centrifugálást (16000 g, 5 perc) követően a mintákat DEPC kezelt desztillált vízbe vettük fel. $15 \mu \mathrm{g}$ RNS-t $4,5 \mu \mathrm{l}$ desztillált vízbe feloldottunk és $2 \mu \mathrm{l} 10 \mathrm{x}$ MOPS puffert, 3,5 $\mu$ l formaldehidet (37\%-os), valamint $10 \mu \mathrm{l}$ deionizált formamidot adtunk hozzá. A deionizáláshoz a formamidot a rezinnel $37{ }^{\circ} \mathrm{C}$-on lassú sebességgel rázattuk, majd a rezint szüréssel eltávolítottuk. A mintákat RNáz-mentes 1x MOPS pufferben futtattuk. Az elválasztott RNS-t, 10x SSC-t használva blottoló pufferként, kapilláris transzferrel átvittük hibridizációs membránra. A hibridizálást a DNS hibridizálással azonos módon végeztük, csupán a hibridizációs puffer összetételében volt eltérés (ld. Anyagok és módszerek, 5.3. fejezet).

\subsubsection{Kompetens Escherichia coli sejtek készítése}

E. coli $\mathrm{TOP}_{10 \mathrm{~F}^{-}}$vagy XL1-Blue sejtek 16 órán át nevelt tenyészet $1 \mathrm{ml}$-ét $100 \mathrm{ml}$ $\mathrm{LB}$ tápoldatba átoltva a baktériumokat $\mathrm{OD}_{660}=0,5-0,6$ érték eléréséig $37{ }^{\circ} \mathrm{C}$-on $200 \mathrm{rpm}$ rázatás mellett növesztettük. A tenyészetet centrifugáltuk $\left(2160 \mathrm{~g}, 10\right.$ perc, $\left.4{ }^{\circ} \mathrm{C}\right)$, majd a sejteket a frissen leoltott tenyészet mennyiségével 1-1 arányban, $100 \mathrm{mM} \mathrm{CaCl} 2$ oldatban felszuszpendáltuk. Centrifugálást ( $2160 \mathrm{~g}, 10$ perc, $\left.4{ }^{\circ} \mathrm{C}\right)$ követően a lépést megismételtük, majd 1 órán át tartó jeges vízfürdőben történő inkubációt követően ismét centrifugáltuk a sejteket $\left(2160 \mathrm{~g}, 10\right.$ perc, $\left.4{ }^{\circ} \mathrm{C}\right)$. A kiülepedett sejteket $1 / 20$ térfogatú hideg, $20 \%$ glicerintartalmú $100 \mathrm{mM} \mathrm{CaCl} 2$ oldatban felszuszpendáltuk. A kompetens sejteket $200 \mu 1$ mennyiségekbe szétadagoltuk, ezeket $-70^{\circ} \mathrm{C}$-on tároltuk ('́gy hónapokig eltarthatók).

\subsubsection{1. $E$. coli sejtek transzformációja}

$200 \mu \mathrm{l}$ fagyasztva tárolt kompetens sejtet jégen felolvasztottunk, majd 5-10 $\mu 1$ ligátumot ( $1 \mu$ lisztított plazmidot) adtunk hozzá. 30 perc $4{ }^{\circ} \mathrm{C}$-on történő inkubáció után 2 percig $42{ }^{\circ} \mathrm{C}$-on tartottuk (hősokk), majd $0,5 \mathrm{ml} \mathrm{LB}$ hozzáadását követően $37^{\circ} \mathrm{C}$-on 1 órán 
keresztül rázattuk. Ezután antibiotikum (ampicillin vagy kloramfenikol) tartalmú LB táptalajra szélesztettük, esetenként IPTG és X-Gal jelenlétében. Gyakran egy másik módszert követtünk (Sambrook és mtsi. 1989): a sejtekhez a plazmid mellett $100 \mu 1$ TCM puffert is adtunk, majd 30 percig $4{ }^{\circ} \mathrm{C}$-on inkubáltuk. Hősokk $\left(3,5\right.$ perc $\left.37^{\circ} \mathrm{C}\right)$ alkalmazása után 10 percig szobahőmérsékleten tartottuk a sejteket, majd ezután antibiotikum tartalmú LB táptalajra szélesztettük, esetenként IPTG és X-Gal jelenlétében. Mindkét módszer esetében a Petri-csészéket $37{ }^{\circ} \mathrm{C}$-on, 16 órán keresztül inkubáltuk, az inszert DNS-t is tartalmazó plazmidokat hordozó transzformánsokra szelektálva.

\subsubsection{Kompetens Agrobacterium tumefaciens sejtek készítése}

Az A. tumefaciens GV3101 törzs rifampicinnel és gentamicinnel kiegészített LB tápoldatban nevelt 24 órás tenyészetéből $3 \mathrm{ml}-\mathrm{t} 300 \mathrm{ml}$ elömelegített, azonos összetételü tápoldatba átoltva, a baktériumokat $\mathrm{OD}_{600}=0,5$ érték eléréséig növesztettük ( $200 \mathrm{rpm}, 28$ $\left.{ }^{\circ} \mathrm{C}\right)$. A tenyészetet 15 percig jégen hütöttük, majd centrifugáltuk $\left(2160 \mathrm{~g}, 15\right.$ perc, $\left.4{ }^{\circ} \mathrm{C}\right)$. A sejteket $10 \mathrm{ml}$ steril desztillált vízzel mostuk, majd újra centrifugáltuk (2160 g, 15 perc, 4 $\left.{ }^{\circ} \mathrm{C}\right)$. Az elektroporációhoz fontos a teljes sómentesítés, ezért egy újabb desztillált vizes mosást végeztünk, majd a sejteket $10 \%$ glicerinben is mostuk. Centrifugálás (2160 g, 15 perc, $4{ }^{\circ} \mathrm{C}$ ) után a sejteket $3 \mathrm{ml} 10 \%$ glicerinben szuszpendáltuk fel, majd $200 \mu \mathrm{l}$ mennyiségenként Eppendorf csövekbe osztottuk szét. A kompetens sejteket $-70{ }^{\circ} \mathrm{C}$-on, fagyasztva tároltuk.

\subsubsection{A. tumefaciens sejtek transzformációja}

A transzformációkat elektroporációval hajtottuk végre. Az A. tumefaciens GV3101 kompetens sejteket jégen felolvasztottuk, majd 3-5 ng plazmidot adtunk a sejtekhez. A szuszpenziót előhütött elektroporáló küvettába (1 mm résszélességü, Epicentre) mértük át. Az elektroporálást Electro Cell Manipulator BCM-600 (BTX Electroporation System) segítségével, 2,5 kV, $25 \mu \mathrm{F}$ és 400 Ohm beállítások mellett hajtottuk végre. Közvetlenül az elektroporáció után a mintákhoz $1 \mathrm{ml}$ SOC tápoldatot adtunk, majd a tápoldatban elkevert sejteket félkémcsőbe mértük át, amit 3 órán keresztül $28{ }^{\circ} \mathrm{C}$-on $150-200$ rpm rázatás mellett regeneráltattunk. A sejteket rifampicin, gentamicin és kanamycin tartalmú LB táptalajra szélesztettük, majd 2 napig $28{ }^{\circ} \mathrm{C}$-on, a transzformáns telepek megjelenéséig inkubáltuk. 


\subsubsection{Protoplasztképzés $M$. circinelloides-ből}

M. circinelloides protoplasztok képzéséhez a sejtek előkészítését kétféle módszerrel végeztük el: csíráztatással vagy celofánon történő neveléssel (Nagy és mtsi. 1994). Csíráztatás

Az MS12 törzs MEA táptalajon, 4-5 napon keresztül, fényben nevelt tenyészetéröl steril desztillált vízzel lemostuk a sporangiospórákat, majd $10^{7} \mathrm{db}$ spórát oltottunk $10 \mathrm{ml}$ YPG tápoldatot tartalmazó lombikba. A spórákat 2 órán át szobahőmérsékleten inkubáltuk, majd 12 órán át $4{ }^{\circ} \mathrm{C}$-on állni hagytuk. Ezután 2-4 órán keresztül $28{ }^{\circ} \mathrm{C}$-on $200 \mathrm{rpm}$-mel rázattuk, míg a spórák átmérőjükkel legalább azonos hosszúságú tömlöt nem fejlesztettek. A csírázó spórákat centrifugáltuk (2160 g, 10 perc) majd 10 mM Nátrium-foszfát pufferrel mostuk.

\section{Celofánon nevelt tenyészetek}

Az MS12 törzs MEA táptalajon, (transzformánsok esetében uracillal vagy leucinnal kiegészített szelektív YNB táptalajon) 4-5 napon keresztül, fényben nevelt tenyészetéről steril desztillált vízzel lemostuk a sporangiospórákat, majd a tömény spóraszuszpenzióból oltótüvel friss, celofánkoronggal fedett YEG táptalajra oltottunk (transzformánsok esetében uracillal vagy leucinnal kiegészített szelektív YNB táptalajon). A tenyészeteket $25{ }^{\circ} \mathrm{C}$-on, 16 órán keresztül neveltük.

A továbbiakat mindkét módszerrel előkészített protoplasztokkal azonos módon végeztük. A két módszer közül a celofánon nevelt tenyészetből történő protoplasztképzés bizonyult hatékonyabbnak, ezért elsősorban ezt a módszert alkalmaztuk. Csíráztatásnál a centrifugált sejteket, celofánon nevelt tenyészeteknél a micéliumkorongokat protoplasztáló oldatba helyeztük, majd 3 órán át $28{ }^{\circ} \mathrm{C}$-on protoplasztáltunk, időnkénti óvatos összerázással elősegítve a képződő protoplasztok leválását. A sejtfal oldásához saját készítésü, éti csiga gyomorból preparált lítikus emésztőenzimet használtunk. SMC pufferrel alaposan átmosva a micéliumkorongokat a protoplasztokat tölcsérbe helyezett gézen keresztül sterilen átszürtük, így megszabadultunk a micéliumtörmeléktöl. A centrifugálással (minden protoplaszt centrifugáláshoz $2160 \mathrm{~g}, 15$ perc, $4{ }^{\circ} \mathrm{C}$ ) összegyüjtött protoplasztokat $5 \mathrm{ml}$ SMC pufferrel mostuk, majd újbóli centrifugálás után $250 \mu 1 \mathrm{SMC}$ pufferbe vettük fel.

\subsubsection{M. circinelloides protoplasztok PEG-mediált transzformációja}

Az általunk alkalmazott módszer van Heeswijck és Roncero (1984) által leírt PEGmediált transzformáció módosítása. A $250 \mu 1$ SMC pufferbe felvett protoplasztokhoz 5-10 $\mu \mathrm{g}$ plazmidot vagy linearizált DNS-t és $20 \mu \mathrm{l}$ PMC puffert adtunk, a protoplasztok és a 
transzformáló DNS összecsapásával elősegítve a transzformációt. Ezután a mintákat fél órán keresztül jégen inkubáltuk. További 2,5 ml PMC puffer hozzáadása után a mintákat 20 percig szobahőmérsékleten inkubáltuk. A mintákat $20 \mathrm{ml}$ SMC pufferrel hígítva centrifugáltuk. A kiülepedett sejtekhez szorbitolt tartalmazó YPG tápoldatot adtunk, majd fél órán át $25{ }^{\circ} \mathrm{C}$-on inkubáltuk őket (protoplasztok regenerációja). Centrifugálás után SMC pufferrel mostuk őket, majd a kiülepített sejteket kis mennyiségü (100-200 $\mu$ l) SMCben szuszpendáltuk és szorbitollal kiegészített YNB fedőagarral összekeverve szorbitolt tartalmazó YNB csészékre öntöttük. Az alkalmazott szelekciós géntől függően a táptalajokat esetenként kiegészítettük uracillal vagy leucinnal. A csészéket 4-10 napig, a transzformáns telepek megjelenéséig szobahőmérsékleten inkubáltuk. REMI transzformáció során annyiban módosítottuk a lépéseket, hogy a protoplasztokat és a linearizált DNS-t tartalmazó elegyhez hozzáadtuk a restrikciós enzimeket (30-30 U), majd 20 perc jégen történő inkubáció után kiegészítettük $20 \mu \mathrm{PMC}$ pufferrel. Fél órán át jégen történő inkubációt követően 1,5 órán keresztül $32-35{ }^{\circ} \mathrm{C}$-on inkubáltuk a protoplaszt elegyet, elősegítve a genomi DNS feldarabolódását. A további lépéseket az előzőekben részletezett módon végeztük.

\subsubsection{A. tumefaciens-közvetített transzformáció (ATMT)}

A transzformációs kísérleteket Bundock és Hooykaas (1996) által leírt, de Groot és munkatársai (1998) által módosított, majd tanszékünkön optimalizált (Nyilasi és mtsi. 2005, 2008, Papp és mtsi. 2010) protokoll szerint végeztük. Az A. tumefaciens sejteket 16 órán keresztül $28{ }^{\circ} \mathrm{C}$-on rifampicinnel, gentamicinnel és kanamycinnel kiegészített LB tápoldatban növesztettük. A tenyészet 1 ml-ével beoltottunk $20 \quad \mathrm{ml} 200 \mu \mathrm{M}$ acetosziringonnal (AS) kiegészített IM indukciós tápoldatot, amit $28{ }^{\circ} \mathrm{C}$-on rázatva $(200$ rpm) $\mathrm{OD}_{660}=0,6$ érték eléréséig neveltünk. Az A. tumefaciens tenyészettel mind spórák, mind protoplasztok transzformációját elvégeztük: a logaritmikus fázisban lévő $A$. tumefaciens tenyészetet összekevertük egyenlő mennyiségü gombaspóra szuszpenzióval $\left(10^{5}-10^{6}\right.$ sporangiospóra/ml) vagy 1:5 arányban gomba protoplasztokkal (a korábban leírt módon végeztük a protoplasztképzést). A keverékeket $200 \mu \mathrm{M}$ AS tartalmú indukciós táptalajra helyezett celofán korongokra szélesztettük (de Groot és mtsi. 1998,). A celofánkorongokat $28{ }^{\circ} \mathrm{C}$-on 1,2 és 3 napig történő együtt-tenyésztés után leucinnal kiegészített YNB táptalajra (szelekciós táptalaj) helyeztük át. Az együtt-tenyésztést folyékony IM tápoldatban is elvégeztük: ekkor $25-28{ }^{\circ} \mathrm{C}$-on, 16 órán keresztül tartó folyamatos rázatás $(150 \mathrm{rpm})$ után centrifugálással $\left(2160 \mathrm{~g}, 15\right.$ perc, $\left.4{ }^{\circ} \mathrm{C}\right)$ összegyüjtöttük 
a sejteket, majd a keveréket szelekciós táptalajra mértük. A baktérium sejtek elpusztításához $200 \mu \mathrm{M}$ cefotaximot is adtunk a táptalajhoz. A Petri-csészéket 4-10 napig, a transzformáns telepek megjelenéséig $25^{\circ} \mathrm{C}$-on inkubáltuk.

\subsubsection{Monosporangiális telepek izolálása és a mitótikus stabilitás vizsgálata}

A járomspórás gombák cönocitikus micéliumának, multinukleáris spóráinak és protoplasztjainak köszönhetően az integratív transzformációt követően heterokariotikus micélium jön létre, ezért a transzformánsok vizsgálatához monosporangiális telepek izolálása szükségesa. Ennek érdekében a szelektív táptalajon nőtt telepek sporangiospóráit desztillált vízzel lemostuk, majd a spóraszuszpenzióból több lépcsőben tízszeres hígítási sort készítettünk és ezekből szélesztettünk ki szelektív táptalajra. Az egy spórából kinövő transzformáns telepeket ezután továbboltottuk szelektív táptalajra. Esetenként egymás után többször (4-5 átoltás), is elvégeztük a monosporangiális telepek izolálását.

A transzformánsok mitótikus stabilitásának vizsgálatát minden transzformáció után elvégeztük. Ennek érdekében néhány transzformáns gombatelepet MEA táptalajon növesztettünk $25^{\circ} \mathrm{C}$-on 4 napig, majd a sporangiospórák lemosása után azokat ismét MEA táptalajra szélesztettük. Ezt 10-15 alkalommal megismételtük, végül a sporangiospórákat szelektív táptalajra oltottuk.

\subsubsection{Karotinoid kivonás}

A $M$. circinelloides MS12 törzsét és a transzformánsokat YNB csészéken 4 napig, állandó megvilágítás mellett tenyésztettük. A tenyésztést különböző környezeti faktorok, valamint különböző táptalajösszetétel mellett is elvégeztük vizsgálva ezek hatását a karotintermelésre.

A micéliumokat steril csipesszel leszedtük a táptalaj felszínéről, majd a micéliumot dörzsmozsárban folyékony nitrogénnel elporítottuk. A karotinoidok fényérzékenysége miatt a teljes folyamatot sötétben végeztük. A karotinoidok extrahálásához 400-500 mg micéliumport használtunk, ehhez $500 \mu \mathrm{l}$ acetont adtunk és erősen vortexeltük néhány percig. A mintákat centrifugáltuk (1000 g, 1 perc), majd a felülúszót egy új csőbe vittük át. Az extrahálást addig ismételtük, amíg a sejttörmelék teljesen színtelen nem lett (6-10 extrakciós lépés). Az extraktumhoz ezután azonos mennyiségü petrolétert $\left(40-70{ }^{\circ} \mathrm{C}\right)$, valamint a fázisok könnyebb szétválása érdekében 1-2 $\mathrm{ml}$ desztillált vizet adtunk. A szerves fázist centrifugálás után új csőbe pipettáztuk át, majd a petrolétert nitrogén gáz áramoltatása mellett elpárologtattuk. A beszáradt karotinoid mintákat $-20{ }^{\circ} \mathrm{C}$-on tároltuk. 


\subsubsection{A karotinoid minták elemzése}

Spektrofotometriás mérés

A beszárított, különböző pigmenteket tartalmazó mintákat petroléterben oldottuk, majd kalibrálás után $450 \mathrm{~nm}$ hullámhosszon határoztuk meg az extinkció értékeket. Extinkciós koefficiensként 2500-al számoltunk (Rodriguez-Amaya 2001).

Vékonyréteg kromatográfia (TLC)

A beszárított, különböző pigmenteket tartalmazó mintákat $50 \mu 1$ etil-acetátba vettük fel. A mintákat szilika gélen $\left(60 \mathrm{~F}_{254}\right.$, Merck) futtattuk, futtatóelegyként aceton és petroléter 20:80 arányú keverékét használtuk.

Nagynyomású folyadékkromatográfia (HPLC)

Kezdetben Hewlett-Packard 1090 Series II. folyadék kromatográfot használtunk automata injektorral. A bepárolt mintákat $1 \mathrm{ml}$ tetrahidrofuránban oldottuk fel közvetlenül az analízis előtt, a mintákból $5 \mu$ l-t injektáltunk az analízishez. Zorbax $\mathrm{SB}_{8} 5 \mu \mathrm{m}(5 \mathrm{x}$ $250 \mathrm{~mm}$ ) oszlopon izokratikus elválasztást végeztünk, a mobil fázis acetonitril/aceton (9:1, $\mathrm{v} / \mathrm{v}$ ) volt $0,6 \mathrm{ml} /$ perc átáramlási sebességgel. A detektálást $480 \mathrm{~nm}$ hullámhosszon végeztük.

A vizsgálatok többségéhez azonban egy moduláris, alacsony nyomású grádiens HPLC rendszert (Shimadzu) használtunk. A bepárolt mintákat $150 \mu 100 \mu \mathrm{g} / \mathrm{ml}$ butilált hidroxitoluénnel (BHT) kiegészített tetrahidrofuránban (TH) oldottuk, amiből $2 \mu \mathrm{l}-\mathrm{t}$ injektáltunk. Az elválasztást Prodigy ODS-3 (4.6 x 150, ODS $3 \mu \mathrm{m})$ oszlopon (Phenomenex) végeztük. Az A oldószer víz és metanol 4:96 arányú elegye, míg a $\mathrm{B}$ oldószer $100 \%$ metil-terc-butil éter volt. Az áramlási sebességet $1 \mathrm{ml} /$ perc értékre állítottuk. Grádiens elválasztást végeztünk a következő paraméterek szerint (perc/A oldószer mennyisége \%-ban/B oldószer mennyisége \%-ban): 0/99/1; 8/60/40; 13/46/54; 15/0/100; 18/0/100; 21/99/1 és 25/99/1. 450 nm hullámhossznál detektáltunk, az oszlop hőmérséklete $35^{\circ} \mathrm{C}$ volt.

A termelt karotinoidok azonosításához a következő gyári standardokat használtunk: asztaxantin, likopin és $\beta$-karotin (Sigma); $\beta$-kriptoxantin és zeaxantin (DHI Water and Environment vagy Carl Roth); kantaxantin (Roche vagy Carl Roth); ehinenon (DHI Water and Environment), míg a $\gamma$-karotint HPLC-vel tisztítottuk M. azygosporus micéliumából. 


\section{EREDMÉNYEK ÉS ÉRTÉKELÉSÜK}

\subsection{Xantofillok termeltetése Mucor circinelloides-ben}

A Paracoccus sp. N81106 törzs $\beta$-karotin - asztaxantin átalakulást biztosító crtZ ( $\beta$-karotin hidroxiláz) illetve $\operatorname{crtW}$ ( $\beta$-karotin ketoláz) génjeinek heterológ expressziójával xantofillok termeltetését valósítottuk meg $M$. circinelloides-ben. Munkám kezdete előtt laboratóriumunkban elkészítettek két expressziós vektort (pPT50 és pPT51, 12. ábra), amelyek az említett géneket hordozzák a $M$. circinelloides gpdl gén promóter és terminális régióinak szabályozása alatt pBluescript $\mathrm{SK}+$ plazmidba (Stratagene) klónozva (Papp és mtsi. 2006). A gpdl génről korábban már kimutatták, hogy ez a promóter régió alkalmas bakteriális gének kifejeztetésére (Appel és mtsi. 2004). A pPT50 vektor tehát a gpdP-crtZgpdT, a pPT51 plazmid pedig a gpdP-crtW-gpdT kazettát hordozta. Szelekciós markerként a pPT50 vektor az uracil auxotrófiát komplementáló pyrG, a pPT51 vektor pedig a leucin auxotrófiát komplementáló leuA gént tartalmazta.
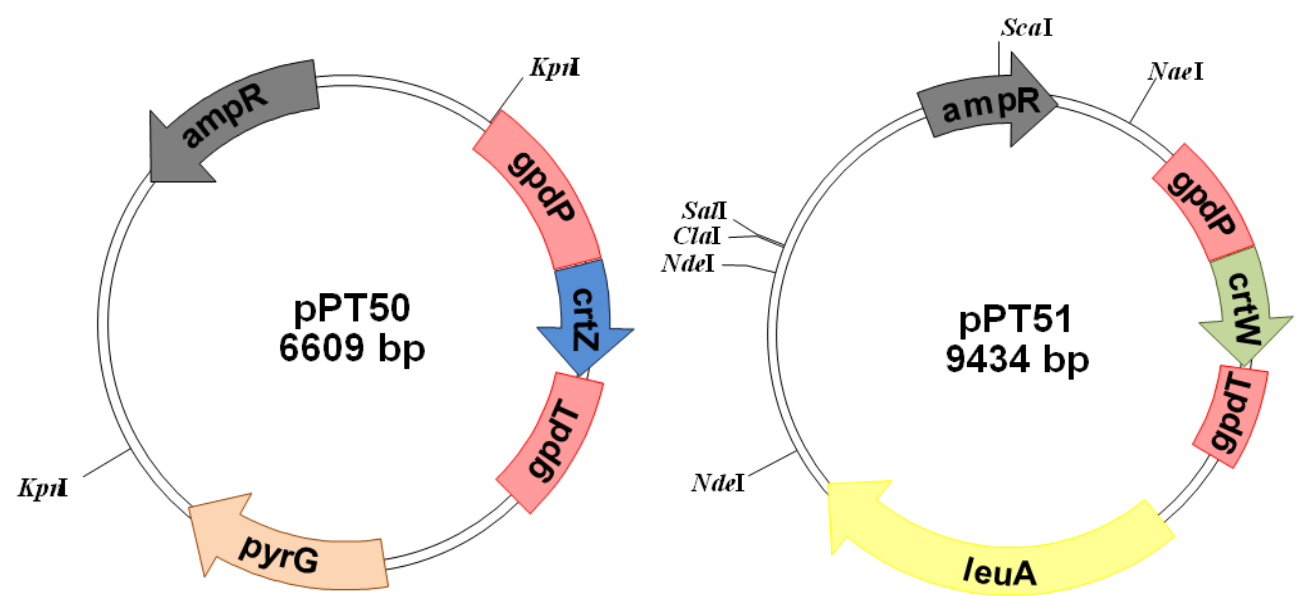

12. ábra. A pPT50 és pPT51 vektorok (Papp és mtsi. 2006).

A pPT50 és pPT51 cirkuláris vektorokkal külön-külön, illetve együttesen is transzformáltuk a $M$. circinelloides kétszeres auxotrófiával (leu`és ura`) markerezett MS12 törzsét. Ezzel kutatócsoportunk elsőként írta le a $M$. circinelloides kotranszformációját (Papp és mtsi. 2006). A nyert transzformánsokat az auxotrófia komplementációja, illetve a színváltozás alapján szelektáltuk. A természetes állapotában sárga gomba színe egyes transzformánsokban megváltozott: a pPT51, illetve a pPT50; pPT51 plazmidokat hordozó törzsek (MS12+crtW és MS12+crtZ; crtW) enyhén rózsaszínes-narancssárgás fenotípust mutattak (13. ábra). A pPT50 (crtZ) vektor önmagában nem okozott fenotípus változást. 


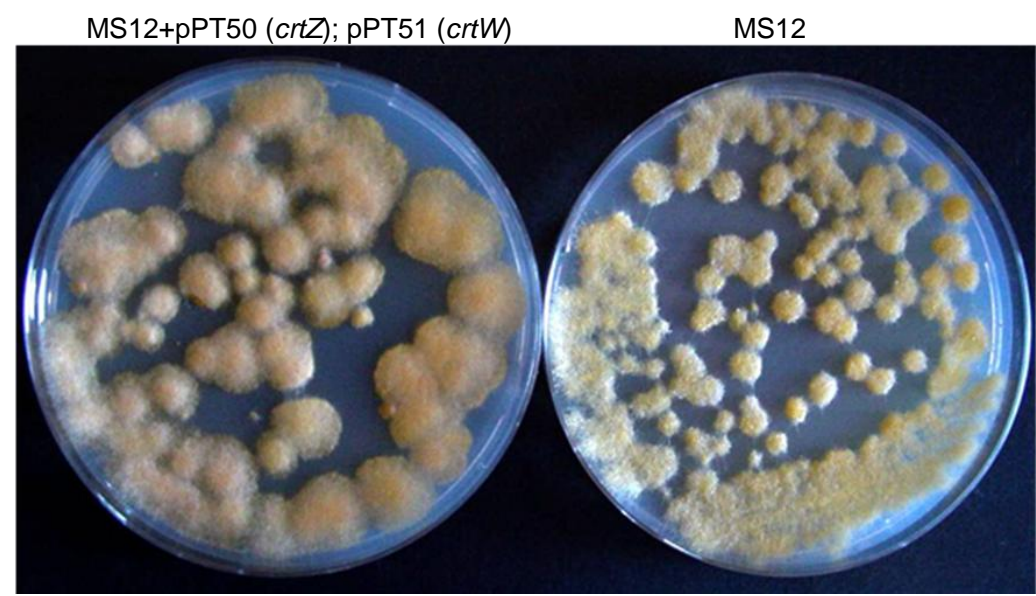

13. ábra. A pPT50 ( $c r t Z)$ és pPT51 ( $c r t W)$ vektorokkal kotranszformált $M$. circinelloides törzs a nemtranszformált MS12-vel összehasonlítva.

A transzformációs gyakoriság viszonylag magas volt: 25-93 telepet izoláltunk 10$15 \mu \mathrm{g}$ DNS $10^{5}$ számú protoplaszthoz történő adásákor. Hasonló gyakoriságot figyeltek meg más kutatócsoportok is (van Heeswijck és Roncero 1984, Iturriaga és mtsi. 1992). A Southern hibridizációs kísérletek igazolták, hogy a transzformánsok autoreplikatív módon tartották fenn a plazmidokat, integrációt nem tudtunk kimutatni egyik vizsgált törzsnél sem. Mint azt az irodalmi áttekintésben is említettem, a járomspórás gombák a bejuttatott cirkuláris DNS-t autonóm replikálódó elemekként tartják fenn, az integráció nagyon ritka esemény. Ibrahim és Skory (2006) megfigyeléseivel összhangban a bejuttatott plazmidok kópiaszáma mindvégig alacsony maradt.

A $c r t W$ és $c r t Z$ géneket próbaként használva a transzformánsokból kinyert RNS mintákkal Northern analízist végeztünk, amellyel sikerült igazolnunk a heterológ gének átíródását. A 14. ábra két kotranszformáns (MS12+pPT50; pPT51) és a kontrollként használt MS12 RNS mintáival végzett hibridizálás eredményét mutatja.

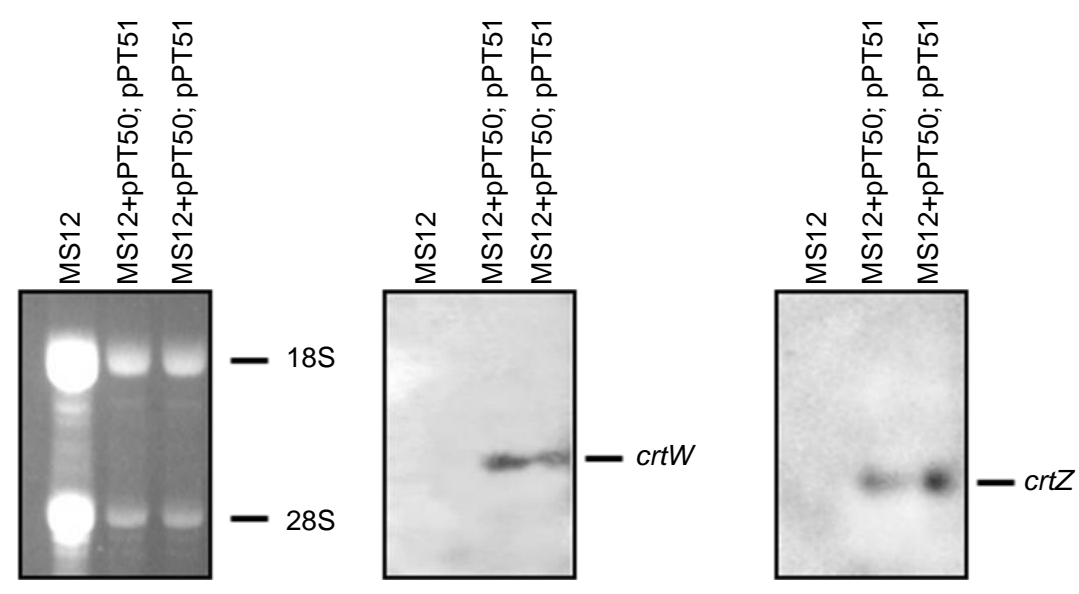

14. ábra. Nem-transzformált, valamint pPT50 ( crtZ) és pPT51 ( crtW) vektorokkal kotranszformált MS12 törzsekkel végzett Northern hibridizáció jelölt $\operatorname{crtW}$ (középen) és a crtZ (jobbra) génpróbákkal. 
Vizsgáltuk a transzformánsok karotin termelését is. A TLC vizsgálatok kimutatták, hogy a transzformánsokban megnőtt a $\beta$-karotin mennyisége és oxigenált $\beta$ karotinszármazékok is jelen vannak. Az MS12+pPT50 (MS12+crtZ) törzs termelt zeaxantint (3,3'-dihidroxi- $\beta, \beta$-karotin) és $\beta$-kriptoxantint (3-hidroxi- $\beta, \beta$-karotin). Azt is kimutattuk, hogy az MS12+pPT51 (MS12+crtW), valamint az MS12+pPT50; pPT51 $(\mathrm{MS12}+\operatorname{crtZ} ; \operatorname{crtW})$ törzsek a $\beta$-karotin mellett ketolált $\beta$-karotinszármazékokat, így ehinenont ( $\beta, \beta$-karotin-4-on), kantaxantint ( $\beta, \beta$-karotin-4,4'-dion), illetve hidroxilált származékokat, mint $\beta$-kriptoxantint, valamint kis mértékben asztaxantint is termeltek (15. ábra).

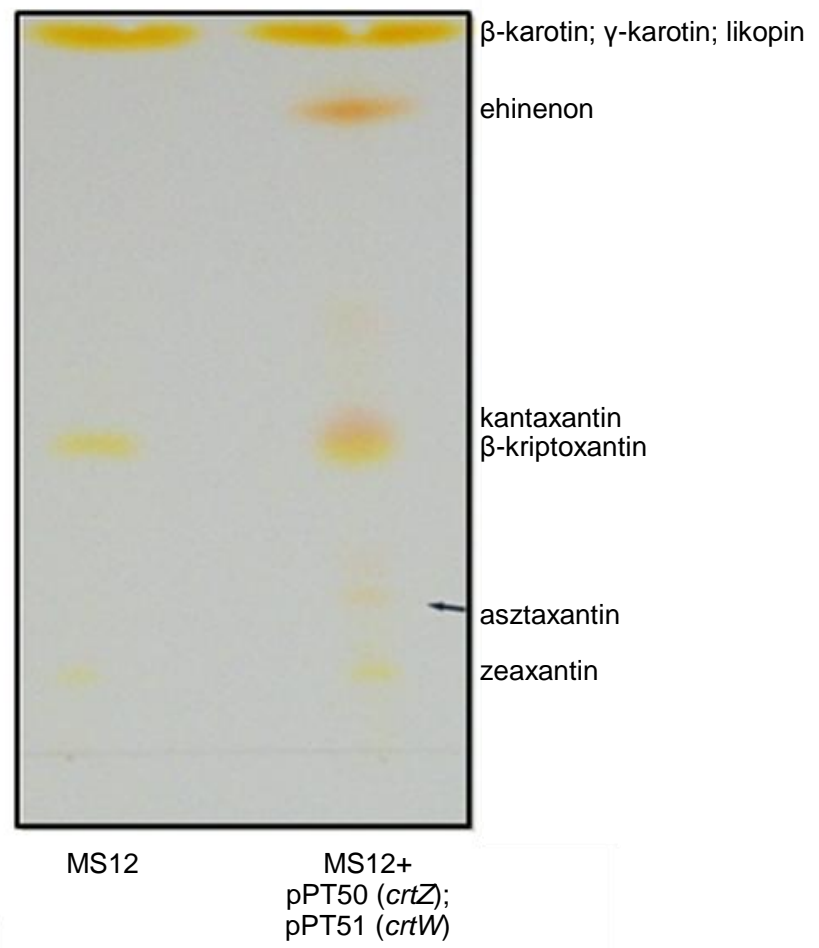

15. ábra. A karotintermelés vizsgálata TLC analízissel. A karotinoid mintákat azonos tömegü micéliumból nyertük.

A karotinoid-termelés mértékét HPLC vizsgálatokkal határoztuk meg (3. táblázat). A mérések megkezdése előtt optimalizáltuk az elválasztás körülményeit a gyári standardokból készített hígítási sorral, illetve meghatároztuk a standardok HPLC spektrumát (16. ábra). A vizsgálatok igazolták azt a némileg meglepő felfedezést, amit már a TLC vizsgálatok alapján is gyanítottunk, hogy az MS12+pPT50 (MS12+crtZ) törzs bár mennyiségileg több karotint termel, de annak összetétele megegyezik a vad típusú MS12 törzsével (3. táblázat). Az MS12 törzs ugyanis szintén felhalmoz zeaxantint és $\beta$ kriptoxantint (a $\beta$-karotin hidroxi-származékait, 17. ábra), ami egyben azt is jelenti, hogy a vad típusú $M$. circinelloides-nek $\beta$-karotin hidroxiláz aktivitása is van, így elvben elegendő 
egy $\beta$-karotin ketoláz (oxigenáz) enzim kifejeztetése ahhoz, hogy a $M$. circinelloides asztaxantint termeljen. Ez összhangban van azzal az eredménnyel is, hogy a csak pPT51 plazmidot hordozó MS12 törzs is képes volt asztaxantin termelésére. A vad típusú és a kotranszformáns törzs HPLC spektruma a 17. ábrán látható.

\begin{tabular}{|c|c|c|c|c|c|c|c|}
\hline Törzs & $\begin{array}{c}\boldsymbol{\beta} \text { - } \\
\text { karotin }\end{array}$ & $\begin{array}{c}\boldsymbol{\beta} \text { - } \\
\text { kriptoxantin }\end{array}$ & Zeaxantin & Kantaxantin & Ehinenon & Asztaxantin & $\begin{array}{c}\text { Teljes } \\
\text { karotinoid }\end{array}$ \\
\hline MS12 & $128(57)$ & $26(12)$ & $4(2)$ & - & - & - & 223 \\
\hline $\begin{array}{c}\text { MS12+ } \\
\text { pPT50 (MS12+crtZ) }\end{array}$ & $146(59)$ & $41(16)$ & $10(4)$ & - & - & - & 249 \\
\hline $\begin{array}{c}\text { MS12+ } \\
\text { pPT51 (MS12+crtW) }\end{array}$ & $155(67)$ & $20(9)$ & - & $6(3)$ & $17(7)$ & $3(1)$ & 231 \\
\hline $\begin{array}{c}\text { MS12+ } \\
\text { pPT50; pPT51 } \\
\text { MS12+crtZ; } \text { crtW) }\end{array}$ & $114(54)$ & $31(15)$ & - & $13(6)$ & $17(8)$ & $2(1)$ & 210 \\
\hline
\end{tabular}

3. táblázat. A transzformánsokban HPLC analízissel mért átlagos karotintermelés szárazsúlyra vonatkoztatva $(\mu \mathrm{g} / \mathrm{g})$. Feltüntettük az egyes karotinoid mennyiségeket, valamint zárójelben azok százalékos arányát is.

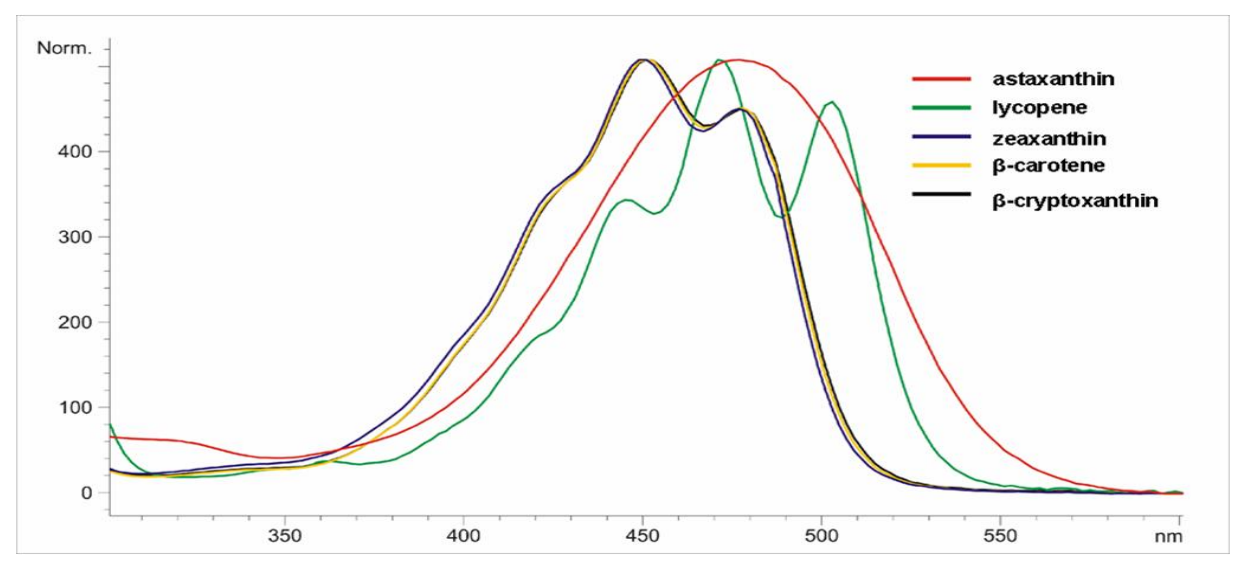

16. ábra. A karotinoid standardok HPLC spektruma.

Az MS12+pPT51 (MS12+crtW) és a kotranszformált MS12+pPT50; pPT51 (MS12+crtZ, crtW) törzsek kantaxantin, ehinenon, valamint asztaxantin termelése bizonyítja, hogy a Paracoccus sp. N81106 törzs $\beta$-karotin - asztaxantin konverzióért felelös génjei Mucor-ban is működnek. Az oxigenált karotinoid-származékok mennyisége azonban nagyon alacsony maradt. Megfigyelhetö, hogy az MS12+pPT51 (MS12+crtW) törzsben alacsonyabb a kantaxantin és a $\beta$-kriptoxantin mennyisége, mint a kotranszformáns törzsben, továbbá egyik törzs sem termel zeaxantint (3. táblázat). Fraser és mtsi. (1997) kimutatták, hogy mind a $\beta$-karotin hidroxiláz, mind a $\beta$-karotin ketoláz többféle szubsztrátot is képes elfogadni, de eltérő affinitással (ld. Irodalmi áttekintés, 9. ábra). Korábbi vizsgálatokban a kantaxantin mennyiségének emelkedése a zeaxantin mennyiségének teljes lecsökkenését okozta, mivel a bioszintézis a kantaxantin irányába 
tolódott el (Fraser és mtsi. 1997). Ez megmagyarázhatja, hogy a pPT51 (crtW) vektort hordozó transzformánsokban miért nem volt kimutatható a zeaxantin.

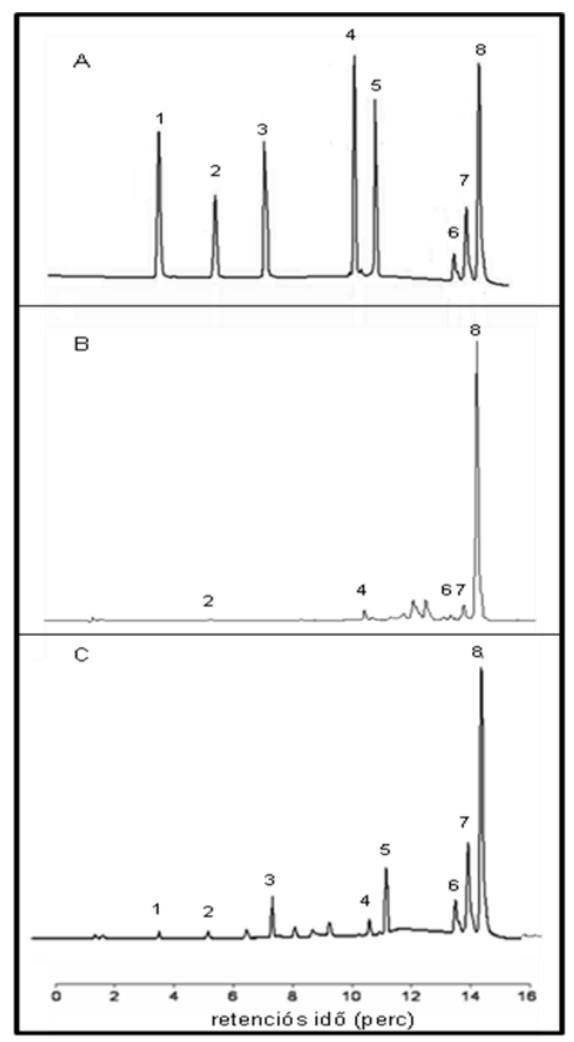

17. ábra. Karotinoid minták HPLC kromatogramja. A számok által jelölt karotinoidok minden esetben: 1: asztaxantin, 2: zeaxantin, 3: kantaxantin, 4: $\beta$-kriptoxantin, 5: ehinenon, 6: likopin, 7: $\gamma$ karotin, 8: $\beta$-karotin.

A: Standardok

B: MS12 nem-transzformált törzs

C: MS12+pPT50; pPT51 (MS12+crtZ; crtW) kotranszformáns törzs.

Az eddigi eredmények alapján szükségesnek tünt a $\beta$-karotin ketoláz génnek a genomba történő integrációja, mivel az oxigenált származékok mennyisége a $\beta$-karotinhoz képest viszonylag alacsony maradt a cirkuláris plazmidokkal képzett transzformánsokban, továbbá az egyes transzformánsokban az új karotinféleségek termelődése meglehetősen ingadozott, feltehetően a bejuttatott plazmidok eltérő kópiaszáma miatt.

A karotinoid-összetétel elemzése során sikerült azonosítanunk egy ismeretlen karotinoid-féleséget, amelyet a crtW gént hordozó transzformánsok nagyobb mennyiségben termeltek. A vegyületet vékonyrétegen, majd a későbbiekben HPLC segítségével tisztítottuk nagyobb mennyiségben. Spektrofotometriás vizsgálatokkal meghatároztuk az ismeretlen karotinoid fényelnyelési görbéjét, majd a fényelnyelési maximumokat. A terméket irodalmi adatok alapján $\gamma$-karotinként azonosítottuk (Rodríguez-Amaya 2001). Hogy az eredményeinket megerősítsük tömegspektrometriás mérés (HPLC-MS/MS) segítségével meghatároztuk a karotinoid molekulatömegét, és a 
vizsgálatok igazolták feltevésünket. Sikerült tehát kimutatnunk, hogy az MS12 törzs termel $\gamma$-karotint, amit a HPLC spektrumokon a likopin, valamint a $\beta$-karotin között megjelenö csúcs jelez (17. ábra).

\section{2. $\beta$-karotin-, valamint xantofillok termeltetésének fokozása $M$. circinelloides-ben} (Csernetics és mtsi. 2011a)

Munkánk ezen részében arra a kérdésre kerestük a választ, hogy a nem karotinspecifikus izoprén bioszintézis út génjeinek túlmüködtetése fokozza-e a karotinoidtermelést; és ha igen, milyen mértékű ez a változás és mely gén túlműködtetése okozza a legnagyobb változást? Három, az izoprén bioszintézis út során feltételezhetően sebességmeghatározó lépést katalizáló enzimet kódoló $M$. circinelloides gént vizsgáltunk: az izopentenil-pirofoszfát átalakulását katalizáló IPP izomerázt (ipi), a geranil-pirofoszfát képződését és átalakulását katalizáló FPP szintázt (isoA) és a farnezil-pirofoszfát átalakulását katalizáló GGPP szintázt ( $\operatorname{carG}$ ). A három gén közül az isoA és carG már vektorokba klónozva állt rendelkezésünkre (pAVB160 és pAVB161 vektorok, Velayos 2000, Velayos és mtsi. 2003, 2004), míg az ipi gént munkánk során azonosítottuk, klónoztuk és jellemeztük.

\subsubsection{Az ipi gén klónozása és jellemzése}

Az ipi gén klónozása egy heterológ expressziós rendszer felállításával történt: kutatócsoportunk E. coli-ban Erwinia uredovora karotinoid-bioszintézis gének expressziójával $\beta$-karotint termelő mutáns törzseket izolált. A cél ezen törzsek $M$. circinelloides cDNS könyvtárral történő transzformációjával karotinoid-túltermelö, illetve karotinoid-bioszintézisben megváltozott mutánsok izolálása, majd a mutánsok genetikai analízise volt. A 60000 izolált telep közül három sötétsárga fenotípusú baktérium telepet sikerült izolálnunk, melyekben igazolható volt a karotinoid-termelés fokozódása. Mindhárom telepből izolált DNS szekvenálása esetén ugyanazt a szekvenciát nyertük. Az azonosított cDNS nagy hasonlóságot mutatott ismert IPP izomerázt kódoló génekkel és tartalmazott egy ezen enzimre jellemző, teljes IPP delta-izomeráz katalitikus domént kódoló szakaszt.

A $M$. circinelloides ipi génjét a határoló régióival együtt PCR alapú módszerrel (ún. kromoszómasétával) izoláltuk, majd jellemeztük. Az azonosított DNS szekvencia egy 910 bp hosszú kódoló régiót és 787 bp upstream és 361 bp downstream határoló régiót tartalmaz, amelyet adatbázisban rögzítettünk (EMBL azonosító: AM903092). A gén egy mindössze 225 aminosavból álló fehérjét kódol (18. ábra) és négy intronnal (57, 57, 61 és 
57 bp) tagolt, mindegyik tartalmazza az intronok 5' végén általánosan megfigyelhető GT, valamint 3' végén az AG motívumokat (Ballance 1990).

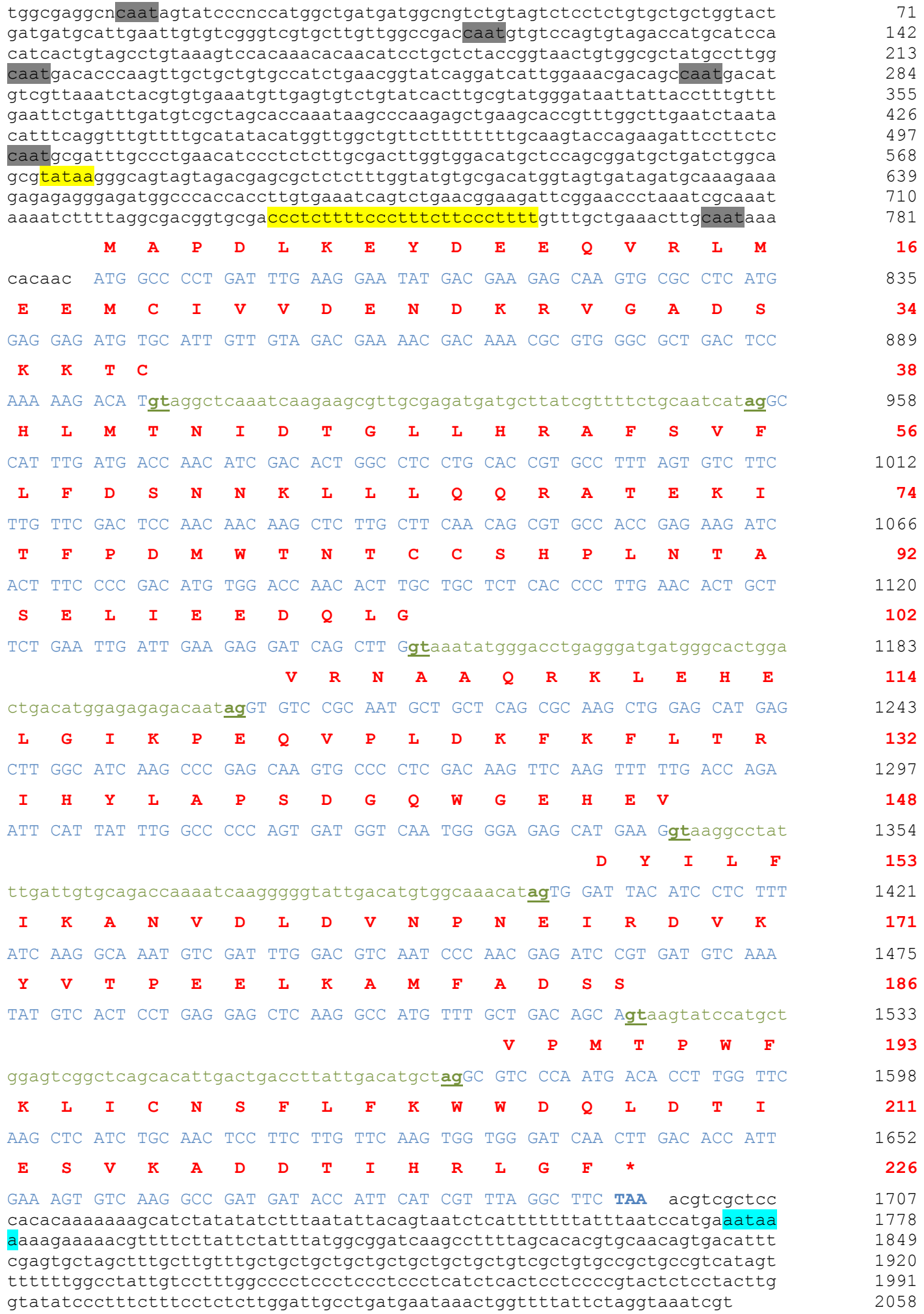

18. ábra. A $M$. circinelloides ipi gén teljes nukleotid és a kódolt fehérje aminosav szekvenciája. Kékkel a gén kódoló részét, zöld betűkkel az intronokat, míg piros betükkel a tripletek által kódolt aminosavakat jelöltük. Az intronok 5' és 3' végén található GT és AG motívumokat külön jeleztük (Ballance 1990). A szabályozó régiókban a jellegzetes szekvencia részleteket kiemeltük. 
A promóter régióban a start kodontól 216 bp upstream helyzetben egy TATA motívumot (TATAA), továbbá több CAAT motívumot és közvetlenül a start kodontól upstream jellegzetes pirimidingazdag régiót azonosítottunk. A terminális régióban a stop kodontól 82 bp downstream helyzetben azonosítottunk egy konszenzus AATAAA poliadenilációs szignál szekvenciát. Ez a szekvencia szinte minden eukarióta gén 3' régiójában változatlanul található meg, azonban fonalas gombákban (elsősorban aszkuszos és bazídiumos gombákban) gyakran hiányzik. Az ipi gén kodonhasználatát is vizsgáltuk: a fonalas gombák körében gyakrabban előforduló TAA STOP kodont azonosítottuk. Tizenkét olyan kodont találtunk, amely nem fordul elő a $M$. circinelloides ipi génjében. Az ipi gép kodonhasználatát a 2. mellékletben mutatjuk be. Az egyes gének kodonhasználatában gyakran tapasztalhatók eltérések, még egyazon organizmus esetében is: a konstitutívan és erősen kifejeződő gének esetében jellegzetes, hogy a 61 aminosavat kódoló kodonnak körülbelül felét használják csak, illetve a kodonhasználatban szigorú szabályok figyelhetők meg (Punt és mtsi. 1988). Ezzel szemben a nem konstitutívan vagy alacsony szinten kifejeződő gének általában az összes rendelkezésre álló kodont használják (Gurr és mtsi. 1987). Az azonosított ipi gén és az általa kódolt fehérje 100\%-os egyezést mutatott a $M$. circinelloides genom adatbázisban található feltételezett IPP izomeráz génnel és annak transzkriptumával (scaffold 02, 4087315-4088347; protein ID: 155452). Fontos megjegyezni, hogy a $M$. circinelloides genom adatbázisa (http://genome.jgipsf.org/Mucci1/Mucci1.home.html) 2008-2009 óta érhető el, míg az ipi gén klónozását évekkel korábban elvégeztük. Az ipi gén cDNS-ét a gén határoló régióival együtt pBluescript SK+ vektorba klónoztuk (pZ4 vektor, 19. ábra).

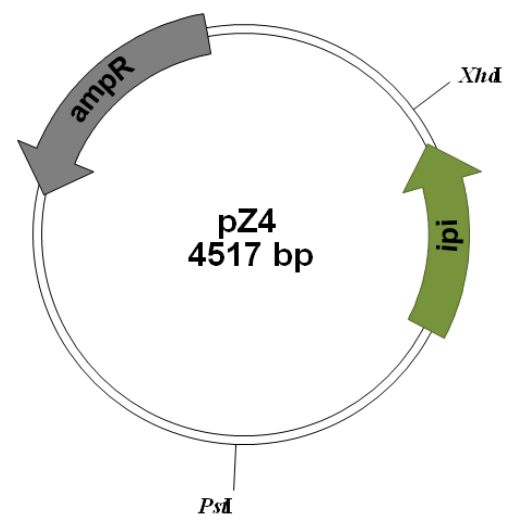

19. ábra. Az ipi gént hordozó pZ4 vektor.

A feltételezett IPP izomeráz molekulatömege 26,124 kDa, katalitikus régiója (18 208 aminosav) a konzervált NUDIX hidroláz doméncsalád jellemzőit (NUcleoside 
jelenlevő gének a géndózis-hatás következtében a $\beta$-karotinszintézis prekurzorainak túltermelését eredményezték. Hasonlóan sikeres kísérleteket végeztek módosított karotintermelő E. coli törzsekkel, ahol az IPP és a GGPP szintáz túlmüködtetése jelentősen megnövelte a karotintermelést (Kajiwara és mtsi. 1997, Wang és mtsi. 1998). A carG müködésének eredményeként szintetizálódó GGPP a karotinszintézis specifikus útjának kiindulási vegyülete, melyet a gomba nem akkumulál; így ennek mennyisége várhatóan nagyban befolyásolja a karotinoidok termelődését.

Rendelkezésünkre állt a $M$. circinelloides isoA génjét tartalmazó pAVB160 (Velayos és mtsi. 2004) és a $M$. circinelloides carG gént hordozó pAVB161 plazmid (Velayos és mtsi. 2003). Mindkét konstrukció leuA szelekciós markerrel rendelkezik (21. ábra). Ahhoz, hogy a génekkel együttes transzformációt hajthassunk végre szükségünk volt olyan vektorra, ahol a pyrG gén biztosítja a szelekciót. A vektor elkészítéséhez a $p y r G$ gént a pEPM901 vektorból (Benito és mtsi. 1992) EcoRI, XbaI restrikciós enzimekkel emésztve kivágtuk, majd a pUC18 vektor azonos hasítóhelyei közé építettünk (pCA1 plazmid). A fent említett pAVB161 plazmid carG génjét PstI és SalI restrikciós endonukleázokkal kivágtuk és beépítettük a pEPM901 vektor PstI és XhoI hasítóhelyei közé (pCA6, 21. ábra), mely így a GGPP szintáz enzimet kódoló carG és a szelekciós pyrG géneket hordozza. A pZ4 vektorból XhoI és PstI enzimekkel kivágtuk az ipi gént és azt a pyrG-t hordozó pEPM901 vektor azonos hasítóhelyei közé építettük (pCA10).

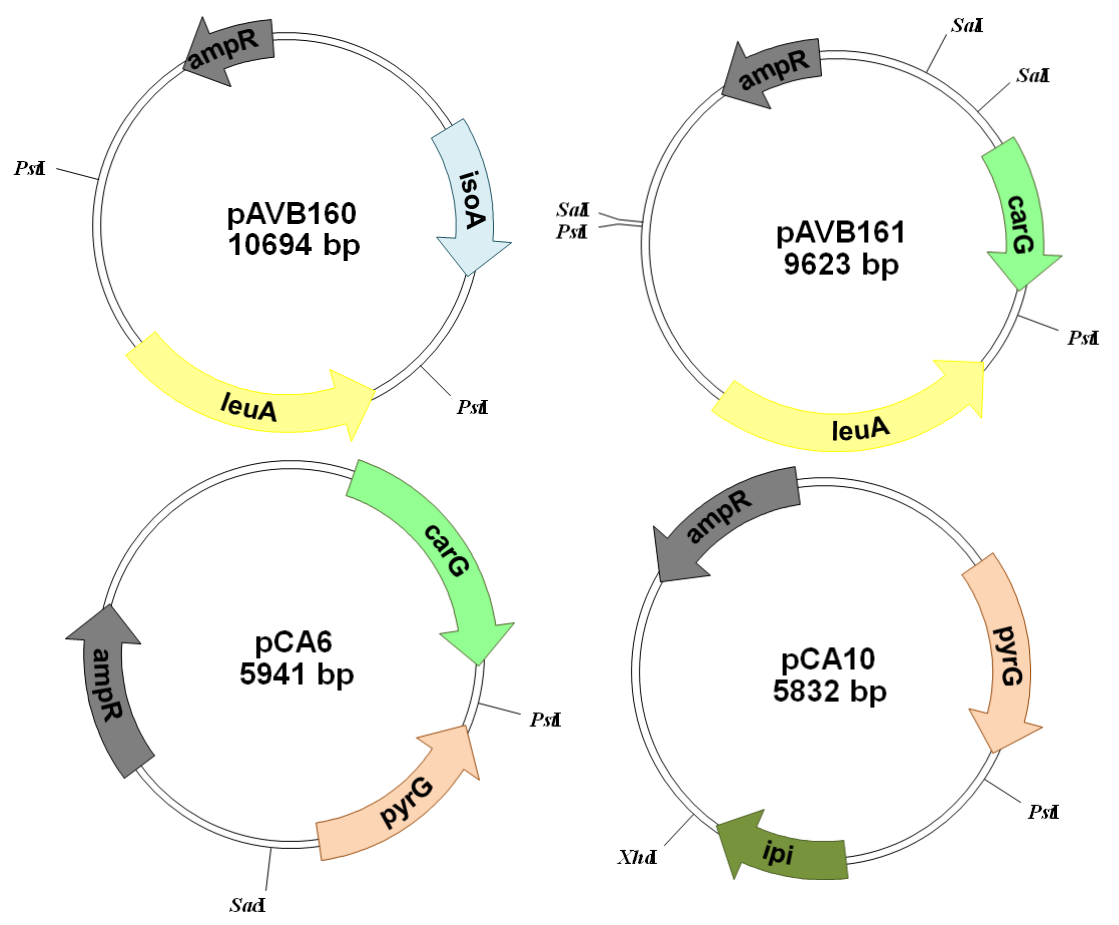

21. ábra. Az izoprén bioszintézis út géneket hordozó transzformáló vektorok pyrG vagy leuA szelekciós markergénnel. 
Létrehoztunk olyan vektor konstrukciókat is, ahol az említett géneket $M$. circinelloides gpdl (glicerinaldehid-3-foszfát dehidrogenáz gén) promóter és terminális régióival építettük össze. Ez egy konstitutívan és erősen kifejeződő promótert jelent, ami ugyanakkor a glükóz koncentráció emelésével indukálható. Ezekhez a vektorokhoz a három vizsgálandó gént (ipi, isoA és carG) PCR technika segítségével amplifikáltuk, majd a felszaporított DNS fragmentumokat EcoRV emésztett pBluescript SK+ klónozó vektorba építettük. Az így nyert vektorokból a felszaporított DNS fragmentumokat XhoI és NotI restrikciós endonukleázok segítségével kivágtuk, majd azokat a pPT43 plazmid (a Mucor gpdl promóter és terminális régióit hordozó vektor, EMBL azonosító: AJ293012, 13-799 és 1831-2470 nukleotidok) azonos hasítóhelyei közé építettük. Korábban több lépésen keresztül a pPT43 vektorba ligáltuk a pyrG gént is: XbaI és PstI restrikciós endonukleázokkal a pEPM901 plazmidból kivágott pyrG gént a pUC18 azonos hasítóhelyei közé ligáltuk, majd a létrehozott plazmidból újra kivágtuk a pyrG gént $S a c$ I és KpnI restrikciós endonukleáz segítségével, majd azt a pPT43 azonos hasító helyei közé raktuk. Az így nyert vektorok a pyrG szelekciós markergén mellett a gpdl promóter és terminális régiói között hordozták az izoprén géneket (pPT82, pPT83, pPT84, 22. ábra). Olyan vektorokat is szerkesztettünk, amelyekben a $p y r G$ gént leuA-ra cseréltük $S m a \mathrm{I}$ és SalI endonukleázokkal (22. ábra).
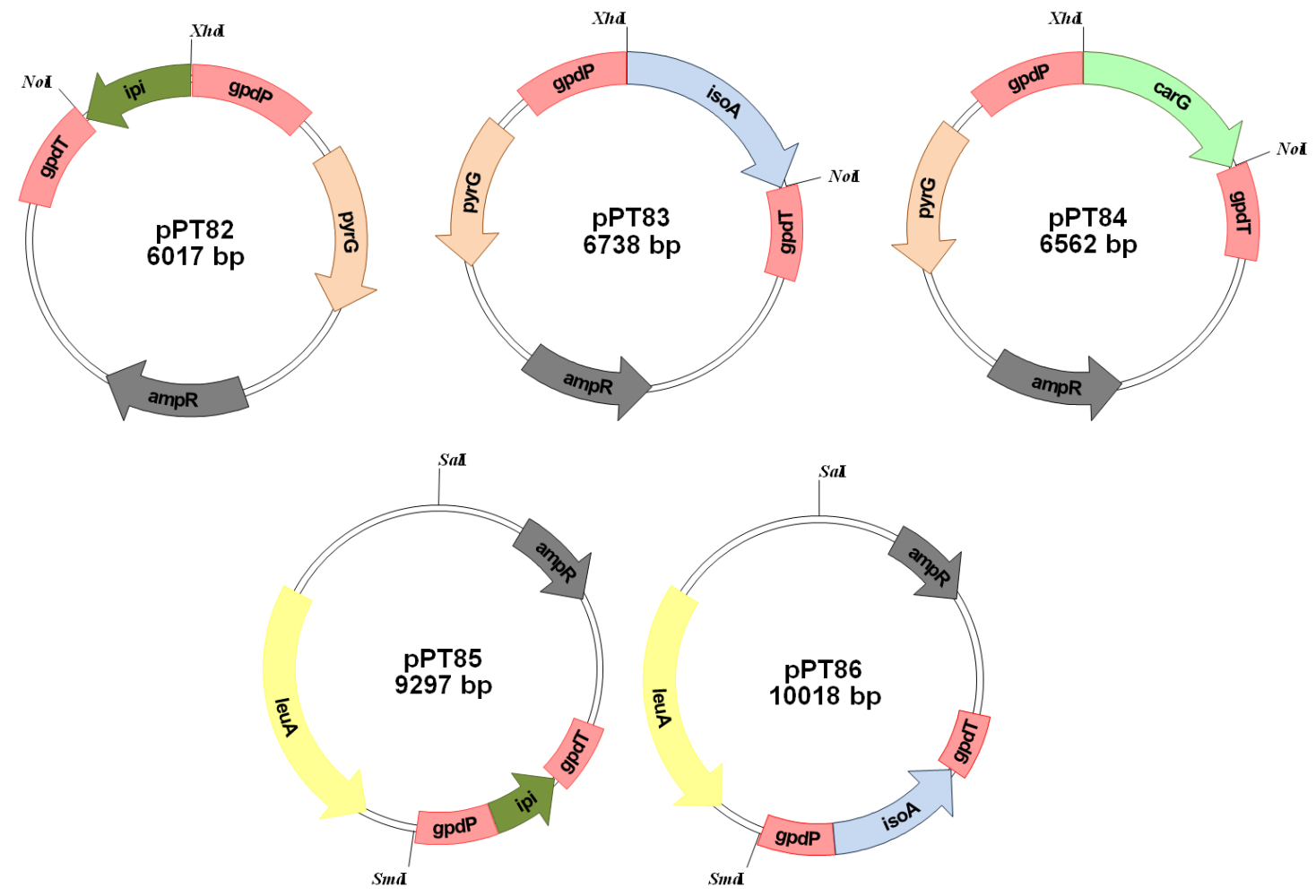

22. ábra. Transzformáló vektorok, ahol az izoprén bioszintézis út három génjét gpdl promóter és terminális régiói közé építettük. 


\subsubsection{A cirkuláris plazmidokkal nyert transzformánsok elemzése}

\section{Transzformációs kísérletek}

A vektorokkal külön-külön, valamint párosával, minden génkombinációval (a megfelelö konstrukció-típusokkal) elvégeztük a $M$. circinelloides MS12 törzs transzformációját. A három izoprén és a bakteriális $c r t W$ gén együttes hatását is vizsgálni kívántuk, ezért a pPT82-84 vektorokkal és a korábban már leírt pPT51 plazmiddal (ld. Eredmények és értékelésük, 6.1. fejezet) párban, mindhárom kombinációban elvégeztük a kotranszformációt. Minden esetben cirkuláris plazmiddal transzformáltunk, a transzformánsokra az auxotrófia komplementálása, valamint a színváltozás alapján szelektáltunk. A kísérletek során nyert transzformánsokat, azok genotípusára és fenotípusára vonatkozó főbb jellemzőket a 4. és az 5. mellékletben foglaltuk össze.

\section{Transzformációs gyakoriság}

A transzformáns telepek a transzformációt követően általában két nap után jelentek meg. A transzformációs gyakoriság átlagosan 15-25 telep volt, 15-20 $\mu$ g plazmid DNS (kotranszformáció esetén 10-10 $\mu \mathrm{g}$ mindkét plazmid DNS-ből), valamint $10^{5}$ protoplaszt mennyiség alkalmazása mellett. Több kutatócsoport hasonló transzformációs gyakoriságot írt le azonos számú protoplasztra és mennyiségű transzformáló DNS-re vonatkoztatva (van Heeswijck és Roncero 1984, Iturriaga és mtsi. 1992), ugyanakkor egyes esetekben magasabb gyakoriságot is leírtak (Benito és mtsi. 1992). A nyert telepek számában nem eredményezett különbséget az, hogy a plazmid milyen szelekciós markergént hordozott, hogy egy vagy két plazmiddal transzformáltunk, illetve, hogy a vektor(ok) homológ vagy heterológ gént hordoztak. Suárez és Eslava (1988) azt tapasztalták Phycomyces esetében, hogy a transzformáló DNS koncentrációjának csökkentése növeli a transzformáns telepek számát, ugyanakkor Heeswijck és Roncero (1984) Mucor esetében épp az ellenkezőjét, tehát a transzformáló DNS koncentrációjának növelésével a transzformáns telepek számának emelkedését írta le, igaz a DNS koncentráció emelésével csökkent az $1 \mu \mathrm{g}$ DNSre számolt transzformációs gyakoriság. Kisebb mértékben ugyan, de Heeswijck és Roncero (1984) megfigyeléseihez hasonló eredményt tapasztaltunk mi is, azaz a transzformáló DNS koncentrációjának emelése kis mértékben növelte a transzformáns telepek számát (25-30 $\mu \mathrm{g}$ DNS alkalmazása esetén 25-30 telepet izoláltunk).

\section{A bejuttatott DNS fennmaradása}

A transzformánsokban a plazmidok jelenlétét PCR technika segítségével mutattuk ki olyan primerek alkalmazásával, amelyek csak a plazmid DNS-ből eredményeznek 
terméket. A Southern hibridizációs kísérletek igazolták, hogy a transzformánsok eredeti méretükben, autonóm replikálódó elemekként hordozzák a bejuttatott plazmidokat. A detektálás során egyértelmüen azonosítani tudtuk a genomi, valamint a plazmid DNS által adott jeleket (23. ábra A, B, C és D panelek). Több minta esetében sikerült a plazmid méreténél kisebb vagy nagyobb méretü további sávokat is detektálni (23. ábra B, C és D panelek), ami felvetette a kérdést: vajon ezek a jelek a transzformáló DNS integrációjából vagy DNS átrendeződésekből erednek? A különböző restrikciós endonukleázokkal történő hasítást követő Southern hibridizáció számos vizsgált minta esetében igazolta a DNS átrendeződéseket (23. ábra $\mathrm{E}$ panel): különböző restrikciós enzimekkel történő emésztés mindig ugyanakkora méretü fragmentumokat eredményezett, tehát a genetikai elem extrakromoszómálisan van jelen a gombában. Hasonló átrendeződéseket más kutatócsoportok is leírtak már (Burmester és mtsi. 1990, Burmester 1992, Arnau és mtsi. 1991, Mackenzie és mtsi. 2000, Monfort és mtsi. 2003). Mindazonáltal az integráció lehetősége sem zárható ki egyes esetekben. Arnau és mtsi. (1991), valamint Arnau és Stroman (1993) a cirkuláris DNS gombagenomba történő integrációját írták le.

Plazmid menekítéses technikát alkalmaztunk a transzformáló DNS visszanyerésére. Ennek során a transzformánsokból tisztított DNS-el transzformáltuk az E. coli kompetens sejteket. A szelekció alapja a plazmidok által hordozott ampicillin rezisztencia gén volt, vagyis azokra a baktérium sejtekre szelektáltunk, amelyekbe bejutott a transzformáló plazmid. Több esetben sikerült a transzformáló DNS méreténél szignifikánsan kisebb cirkuláris elemeket izolálnunk (általában 3 kb méret körül), ami megerősíti a hibridizációs kísérletek során megfigyelt átrendeződéseket. Ugyanakkor, 5 kb-nál nagyobb méretü sávoknak megfelelő elemeket (nagyobb méretüek a bejuttatott plazmidok is) nem sikerült izolálnunk. Ezt a jelenséget korábban más kutatócsoportok szintén leírták (Arnau és mtsi. 1991). A menekített plazmidok szekvenciáinak meghatározása igazolta, hogy azok az eredeti transzformáló DNS-böl erednek: hordozzák az ampicillin rezisztencia gént, néhány esetben a pyrG gént vagy annak egy szakaszát, valamint plazmid szekvencia részeket, így pl. minden esetben a lac $Z$ gén több szakaszát. Gyakran néhány nukleotid hosszúságú, nem plazmid eredetű szekvencia részleteket is találtunk, amelyek a Mucor genomból származhatnak. Az izolált genetikai elemek egyik esetben sem hordozták az izoprén géneket, illetve azok részleteit, ami megmagyarázza, hogy miért nem detektáltunk hibridizációs jelet a visszanyert plazmidokkal azonos méretben. Ugyanakkor további kérdések fogalmazódtak meg bennünk ezen elemek kapcsán: vajon stabilan fennmaradnak és replikálódnak a gombában vagy további átrendeződések történnek, esetleg eliminálódnak? 

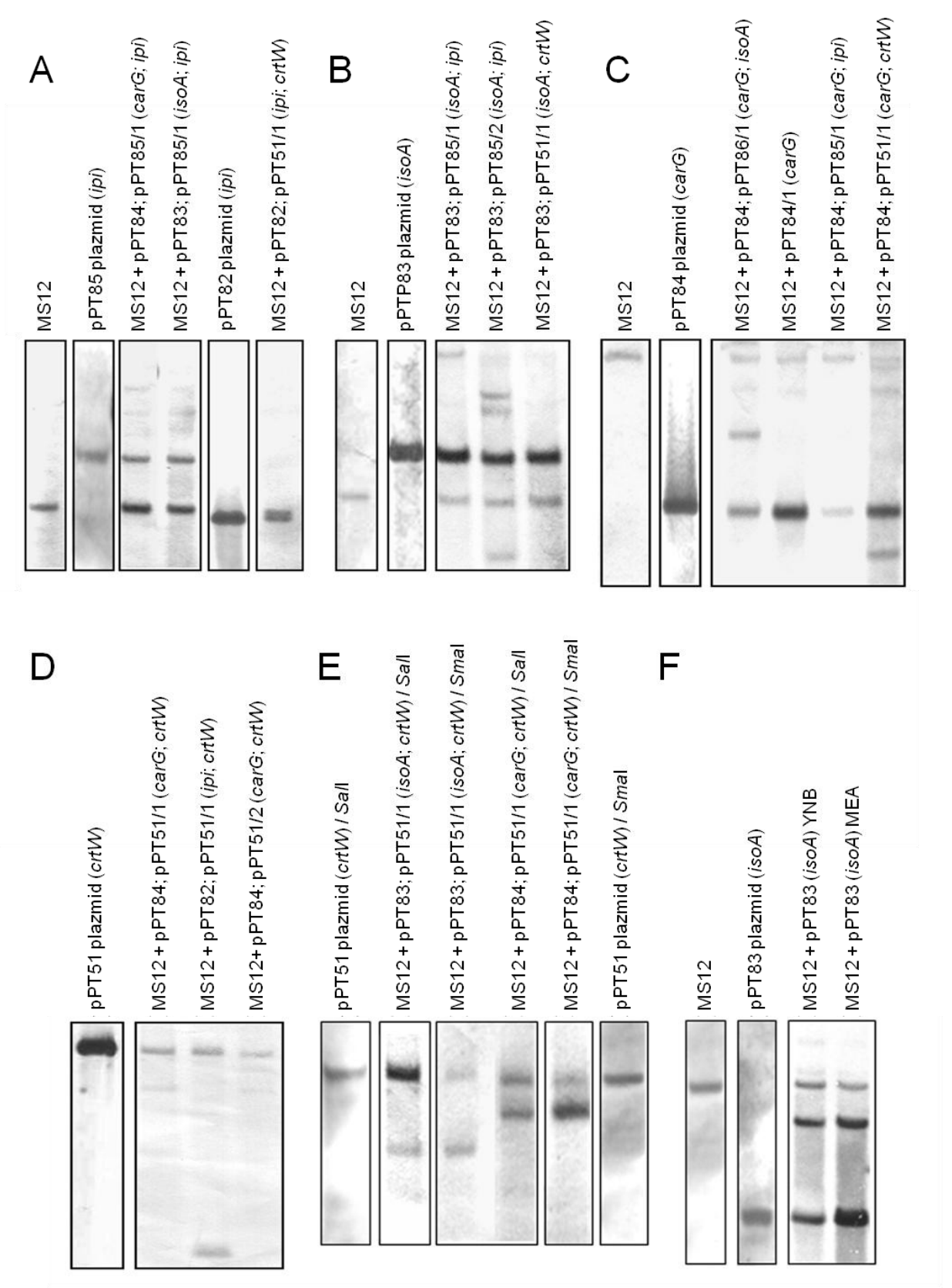

23. ábra. Példák a Southern hibridizációs kísérletekre.

A: XhoI enzimmel emésztett minták hibridizációja jelölt ipi génpróbával.

B: XhoI enzimmel emésztett minták hibridizációja jelölt isoA génpróbával.

C: XhoI enzimmel emésztett minták hibridizációja jelölt carG génpróbával.

D: ClaI enzimmel emésztett minták hibridizációja jelölt crtW génpróbával.

E: SalI és SmaI enzimekkel külön-külön emésztett minták hibridizációja jelölt crtW génpróbával.

F: MS12+pPT83 transzformáns törzs YNB illetve MEA táptalajokon tíz cikluson keresztül történő tenyésztés után tisztított, XbaI enzimmel emésztett DNS mintáinak hibridizációja isoA génpróbával.

\section{Plazmid kópiaszám és mitótikus stabilitás}

Meghatároztuk a transzformánsokba bejuttatott plazmidok relatív kópiaszámát minden transzformáns esetében, több átoltásból izolált telepből, qPCR technika segítségével. A kísérletek megkezdése előtt optimalizáltuk az amplifikálás körülményeit. 
Amikor az MS12 törzsböl izolált DNS-t használtuk templátként, az ipi, isoA és carG gének amplifikációs jelei azonos ciklusban érték el az érzékelési küszöbértéket (24. ábra). Ez jó lehetőséget nyújtott arra, hogy a kópiaszám meghatározáshoz belső kontrollként alkalmazzuk azokat a géneket, amelyeket nem jutattunk be további kópiában a gombába. A kísérletek egyben igazolták azt a korábbi feltevést is, hogy mind a három izoprén gén egy kópiában van jelen a Mucor genomban. A crtW bakteriális gén esetében a kontroll kísérleteket a pPT51 plazmid hígítási sorozatának segítségével végeztük el.

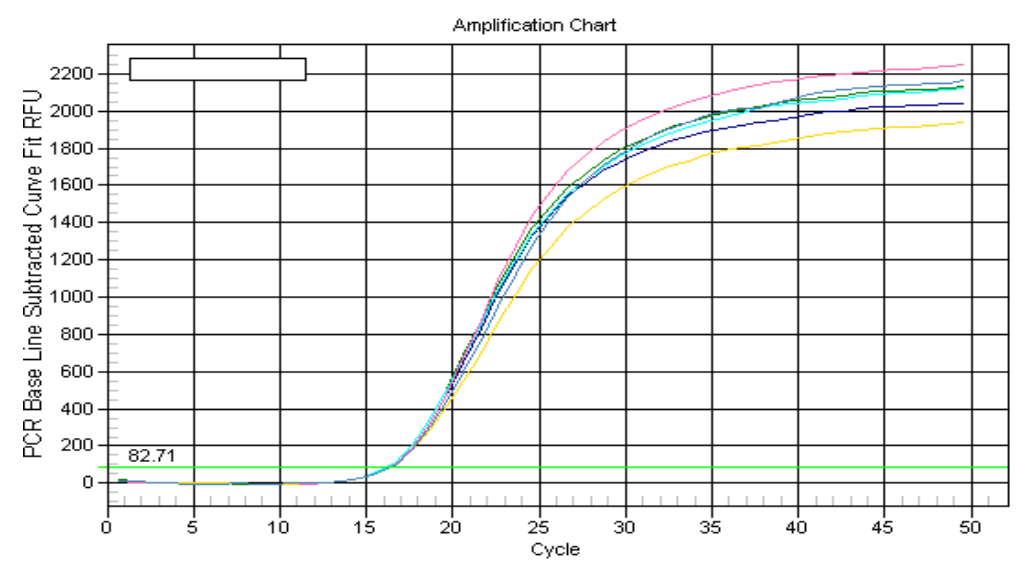

24. ábra. Valós idejű PCR kontroll kísérletek. A három izoprén gén (ipi, isoA és carG) azonos ciklusban éri el a küszöbértéket (két párhuzamost alkalmaztunk a mérések során).

A plazmid kópiaszám meghatározást egy transzformáns több monosporangiális telepéből izolált DNS-sel is elvégeztük. A transzformánsokban az izoprén géneket hordozó plazmidok kópiaszáma 0,3 és 7 kópia/gazdagenom között adódott, hasonló értékeket mértek Appel és mtsi. (2004). A bakteriális gént hordozó pPT51 plazmid kópiaszáma azonban alacsonyabbnak bizonyult, általában $<1$ kópia/genom volt (0,07-0,8 kópia/genom között változott). A kotranszformánsokban a két plazmid kópiaszáma általában eltért egymástól (4. táblázat).

Mind szelektív, mind nem szelektív körülmények között történő, többszöri (10-15 ciklus) egymást követő átoltás után vizsgáltuk a transzformánsok mitótikus stabilitását. A vizsgált transzformánsok stabilnak bizonyultak mindkét körülmény között, függetlenül attól, hogy mely szelekciós gént hordozta a plazmid vagy attól, hogy egy vagy két plazmidot hordozó transzformánsról volt-e szó. Az sem befolyásolta a mitótikus stabilitást, hogy a plazmid homológ vagy heterológ gént hordozott, ami némileg meglepő, hiszen korábban heterológ gént hordozó plazmiddal történő transzformáció esetében általában nagyfokú instabilitást írtak le járomspórás gombáknál (Ruiz-Hidalgo és mtsi. 1999, Wolff és Arnau 2002, Ortiz-Alvarado és mtsi. 2006, Lukács és mtsi. 2009). Azt azonban meg kell 
említenünk, hogy a transzformánsok ugyan stabilak voltak, de szükséges volt a tárolásuk során a kéthavonkénti átoltás. A plazmid kópiaszám tekintetében megállapítható, hogy egy vagy két átoltási ciklus után nem változott jelentős mértékben, de többszöri átoltás a plazmid kópiaszám fluktuációját eredményezte, ami gyakran a kópiaszám jelentős mértékü emelkedését jelentette (4. táblázat). A várttal ellentétben a nem szelektív körülmények között történő tenyésztés során sem csökkent a kópiaszám, holott az irodalomban a nagyfokú mitótikus instabilitást általában a plazmid elvesztésével magyarázták.

\begin{tabular}{|c|c|c|}
\hline Törzs & $\begin{array}{c}\text { Relatív plazmid } \\
\text { kópiaszám (kópia/genom) }\end{array}$ & $\begin{array}{l}\text { Összkarotinoid- } \\
\text { tartalom }(\mu \mathrm{g} / \mathrm{g})\end{array}$ \\
\hline MS12 & - & $399 \pm 27$ \\
\hline MS12 + pCA10 (ipi) & 1 & $674 \pm 230$ \\
\hline $\mathrm{MS} 12+\mathrm{pAVB} 160$ (isoA) & $0,3-1$ & $584 \pm 126$ \\
\hline MS12 + pCA6 (carG) & $6-7$ & $718 \pm 110$ \\
\hline $\begin{array}{c}\text { MS12 + pCA10 (ipi); } \\
\text { pAVB160 (isoA) }\end{array}$ & $\begin{array}{l}3 \\
1 \\
\end{array}$ & $1392 \pm 396$ \\
\hline $\begin{array}{l}\text { MS12 + pCA10 (ipi) } \\
\text { pAVB161 (carG) }\end{array}$ & $\begin{array}{c}2 \\
0,3-1\end{array}$ & $745 \pm 149$ \\
\hline $\begin{array}{c}\mathrm{MS} 12+\mathrm{pAB} 160(\text { isoA }) \\
\text { pCA6 }(\text { carG })\end{array}$ & $\begin{array}{l}2 \\
2\end{array}$ & $808 \pm 148$ \\
\hline MS12 + pPT85 (ipi*) & 2 & $1177 \pm 218$ \\
\hline $\mathrm{MS} 12+\mathrm{pPT} 83\left(\right.$ isoA $\left.^{*}\right)$ & $3-6$ & $1209 \pm 81$ \\
\hline MS12 + pPT84 (carG*) & $2-4$ & $1959 \pm 389$ \\
\hline $\begin{array}{l}\text { MS12 + pPT85 }\left(i p i^{*}\right) \\
\text { pPT83 }\left(i s o A^{*}\right)\end{array}$ & $\begin{array}{l}4-6 \\
1-4 \\
\end{array}$ & $1504 \pm 141$ \\
\hline $\begin{array}{l}\text { MS12 + pPT85 }\left(i p i^{*}\right) \\
\text { pPT84 }\left(\operatorname{carG}^{*}\right)\end{array}$ & $\begin{array}{l}5 \\
2\end{array}$ & $1004 \pm 180$ \\
\hline $\begin{array}{c}\mathrm{MS} 12+\mathrm{pPT} 86\left(\text { iso }^{*}\right) \\
\text { pPT84 } \\
\text { (carG }\end{array}$ & $\begin{array}{l}1-6 \\
1-4\end{array}$ & $1298 \pm 350$ \\
\hline $\begin{array}{c}\text { MS12 + pPT82 }\left(i p i^{*}\right) \\
\text { pPT51 }(\text { crtW })\end{array}$ & $\begin{array}{l}2 \\
1\end{array}$ & $1053 \pm 98$ \\
\hline $\begin{array}{c}\mathrm{MS} 12+\mathrm{pPT} 83\left(\text { iso }^{*}\right) \\
\text { pPT51 }(\operatorname{crt} W)\end{array}$ & $\begin{array}{c}3 \\
0,2\end{array}$ & $807 \pm 35$ \\
\hline $\begin{array}{c}\text { MS12 + pPT84 }\left(\operatorname{car} G^{*}\right) \\
\text { pPT51 }(\operatorname{crt} W)\end{array}$ & $\begin{array}{c}7 \\
0,07\end{array}$ & $924 \pm 146$ \\
\hline
\end{tabular}

4. táblázat. Öt független tenyésztés során a transzformánsokból izolált DNS-ből valós idejü PCR segítségével meghatározott relatív plazmid kópiaszámok átlaga (kópia/genom). A táblázatban a szárazanyagtartalomra vonatkoztatott összkarotinoid-tartalmak is láthatók. A csillaggal jelzett izoprén gének gpdl promóter és terminális régiók szabályozása alatt állnak.

Mindezen eredmények igazolják, hogy a korábbi feltevésekkel ellentétben az integráció nem szükségszerü a stabil transzformánsok elöállításához. Ez azonban felveti azt a kérdést, hogy azok a transzformánsok, amelyekben a kutatók a stabilitás alapján látták igazoltnak az integrációs eseményeket, valóban integratívak voltak-e? Southern hibridizációs kísérletekkel igazoltuk, hogy a szelekciós nyomás hiánya nem okozta a 
plazmid DNS eliminációját, sem azon magok szelekcióját, melyek genomjába esetlegesen integrálódott a transzformáló DNS vagy annak egy darabja. (23. ábra, F panel). A hibridizációs mintázatból azt is megfigyeltük, hogy egy monosporangiális eredetű telepről nyert spórákból továbboltott, majd egymástól függetlenül nevelt tenyészetekből izolált DNS-ekből azonos méretben volt kimutatható egy plazmid átrendeződésből eredő jel. A kis mintaszám miatt általánosítani nem lehet, ez az eredmény azonban igazolhatja, hogy ezek a genetikai elemek bizonyos esetekben stabilan fennmaradhatnak, replikálódhatnak, valamint a vegetatív spórák révén öröklődhetnek.

\section{Transzkripció elemzése}

Mielőtt megkezdtük volna a transzformáns törzsek vizsgálatát, valós idejü PCR segítségével megmértük az MS12 törzs izoprén génjeinek az aktinhoz, valamint egymáshoz viszonyított relatív transzkripciós szintjeit, a transzkripciós szintek időbeni, valamint a glükóz koncentráció fokozásával járó esetleges változását. Az aktinnal összehasonlítva mindhárom gén transzkripciós szintje alacsony volt. Négy órával az inokuláció után az ipi és $i s o A$ gének sokkal magasabb transzkripciós szintet mutattak, mint a $\operatorname{car} G$ gén. Ez az időpont a sporangiospórák csírázásának megindulásával esik egybe. Az idő előrehaladtával a két gén transzkripciós szintje radikálisan csökkent és egy viszonylag alacsony szinten stabilizálódott. A carG folyamatosan alacsony transzkripciós szintet mutatott. A csírázás megindulásának időpontját kivéve az ipi relatív transzkripciós szintje folyamatosan a másik két gén kétszeresének adódott (25. ábra). A glükóz koncentráció fokozása pedig némileg csökkentette mindhárom gén transzkripcióját (5. táblázat).

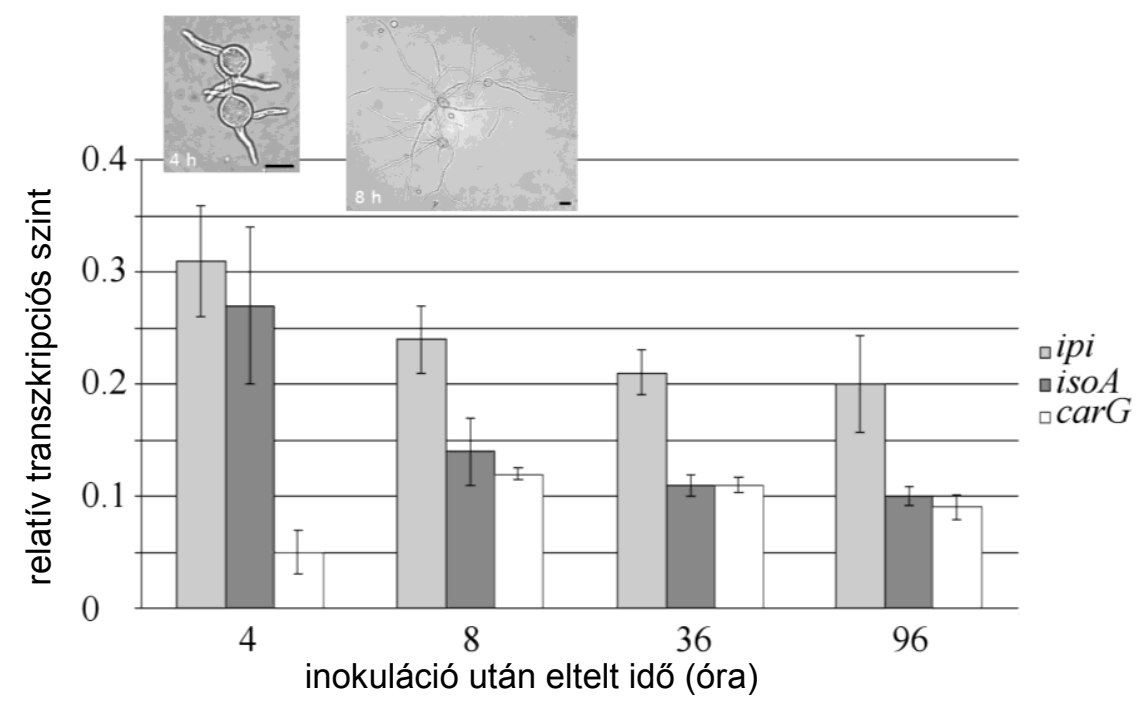

25. ábra. Az MS12 törzs három izoprén génjének az aktinhoz viszonyított relatív transzkripciós szintje az inokulációtól eltelt idő függvényében ábrázolva, 4, 8, 36 és 96 óra eltelte után. Az ábra felső részén látható két képen 4 óra után csírázó spórák, 8 óra után növekvő hifák láthatók. 


\begin{tabular}{|c|c|c|c|c|}
\hline Törzs & $\begin{array}{c}\text { Glükóz } \\
\text { koncentráció (\%) }\end{array}$ & $\begin{array}{c}\text { Relatív } \\
\text { transzkripciós szint }\end{array}$ & $\begin{array}{l}\text { Összkarotinoid- } \\
\text { tartaloma }(\mu \mathrm{g} / \mathrm{g})\end{array}$ & $\begin{array}{c}\text { Szárazanyag } \\
\text { tömeg }^{\text {b }}(\mathrm{g})\end{array}$ \\
\hline \multirow{3}{*}{ MS12 } & 1 & kontroll $^{\mathrm{c}}$ & $399 \pm 27$ & 0,08 \\
\hline & 2,5 & $\begin{array}{l}\text { ipi: } 0,6 ; \text { isoA: } 0,7 ; \\
\quad \text { carG: } 0,7\end{array}$ & $490 \pm 48$ & 0,107 \\
\hline & 5 & $\begin{array}{l}\text { ipi: } 0,4 ; \text { isoA: } 0,5 ; \\
\quad \text { carG: } 0,4\end{array}$ & $436 \pm 37$ & 0,151 \\
\hline \multirow{3}{*}{ MS12 + pPT85 (ipi) } & 1 & 11 & $1177 \pm 218$ & 0,099 \\
\hline & 2,5 & 61 & $1375 \pm 575$ & 0,130 \\
\hline & 5 & 49 & $1102 \pm 431$ & 0,171 \\
\hline \multirow{3}{*}{ MS12 + pPT83 (isoA) } & 1 & 17 & $1209 \pm 81$ & 0,103 \\
\hline & 2.5 & 50 & $1164 \pm 132$ & 0,159 \\
\hline & 5 & 52 & $1104 \pm 210$ & 0,169 \\
\hline \multirow{3}{*}{ MS12 + pPT84 (carG) } & 1 & 6 & $1959 \pm 389$ & 0,113 \\
\hline & 2,5 & 49 & $1341 \pm 98$ & 0,142 \\
\hline & 5 & 44 & $1164 \pm 37$ & 0,166 \\
\hline \multirow{3}{*}{$\begin{array}{l}\text { MS12 + pPT85 (ipi*); } \\
\text { pPT83 (isoA*) }\end{array}$} & 1 & $\begin{array}{l}\text { ipi: } 18 \\
\text { isoA: } 34\end{array}$ & $1504 \pm 141$ & 0,101 \\
\hline & 2,5 & $\begin{array}{l}\text { ipi: } 26 \\
\text { isoA: } 57\end{array}$ & $1407 \pm 191$ & 0,179 \\
\hline & 5 & $\begin{array}{l}\text { ipi: } 32 \\
\text { isoA: } 33\end{array}$ & $1379 \pm 415$ & 0,207 \\
\hline \multirow{3}{*}{$\begin{array}{l}\mathrm{MS} 12+\mathrm{pPT} 85\left(i p i^{*}\right) \\
\text { pPT84 }\left(\text { carG }^{*}\right)\end{array}$} & 1 & $\begin{array}{l}\text { ipi: } 9 ; \\
\text { carG: } 2\end{array}$ & $1004 \pm 180$ & 0,11 \\
\hline & 2,5 & $\begin{array}{l}\text { ipi: } 13 ; \\
\text { carG: } 4\end{array}$ & $983 \pm 174$ & 0,156 \\
\hline & 5 & $\begin{array}{l}\text { ipi: } 12 \\
\text { carG: } 3\end{array}$ & $758 \pm 150$ & 0,212 \\
\hline \multirow{3}{*}{$\begin{array}{l}\text { MS12 + pPT86 (isoA*); } \\
\left.\text { pPT84 (carG } G^{*}\right)\end{array}$} & 1 & $\begin{array}{l}\text { isoA: } 9 \\
\text { carG: } 8\end{array}$ & $1298 \pm 350$ & 0.098 \\
\hline & 2,5 & $\begin{array}{l}\text { isoA: } 17 \\
\text { carG: } 34\end{array}$ & $875 \pm 33$ & 0,156 \\
\hline & 5 & $\begin{array}{l}\text { isoA: } 16 \\
\text { carG: } 10\end{array}$ & $729 \pm 37$ & 0,187 \\
\hline \multirow{3}{*}{$\begin{array}{c}\mathrm{MS} 12+\text { pPT82 }\left(i p i^{*}\right) \\
\text { pPT51 }(\mathrm{crtW})\end{array}$} & 1 & $\begin{array}{l}\text { ipi: } 18 \\
\text { crtW: } 17\end{array}$ & $1053 \pm 98$ & 0,108 \\
\hline & 2,5 & $\begin{array}{l}\text { ipi: } 26 ; \\
\text { crtW: } 16\end{array}$ & $1111 \pm 100$ & 0,170 \\
\hline & 5 & $\begin{array}{c}\text { ipi: } 32 \\
\text { crtW: } 20\end{array}$ & $629 \pm 66$ & 0,208 \\
\hline \multirow{3}{*}{$\begin{array}{c}\text { MS12 + pPT83 }(\text { isoA } *) \\
\text { pPT51 }(\operatorname{crt} W)\end{array}$} & 1 & $\begin{array}{l}\text { isoA: } 16 \\
\text { crtW: } 6\end{array}$ & $807 \pm 35$ & 0,120 \\
\hline & 2,5 & $\begin{array}{l}\text { isoA: } 29 \\
\text { crtW: } 7\end{array}$ & $809 \pm 32$ & 0,143 \\
\hline & 5 & $\begin{array}{l}\text { isoA: } 29 ; \\
\text { crtW: } 3\end{array}$ & $702 \pm 13$ & 0,197 \\
\hline \multirow{3}{*}{$\begin{array}{c}\text { MS12 + pPT84 }\left(\operatorname{car} G^{*}\right) \\
\text { pPT51 }(\operatorname{crt} W)\end{array}$} & 1 & $\begin{array}{l}\operatorname{carG}: 9 ; \\
\operatorname{crt} W: 34\end{array}$ & $924 \pm 146$ & 0,110 \\
\hline & 2,5 & $\begin{array}{l}\operatorname{carG:}: 10 \\
\operatorname{crtW}: 29\end{array}$ & $895 \pm 46$ & 0,151 \\
\hline & 5 & $\begin{array}{l}\operatorname{carG:}: 17 \\
\operatorname{crt} W: 53\end{array}$ & $742 \pm 130$ & 0,206 \\
\hline
\end{tabular}

5. táblázat. A glükóz koncentráció hatása a vizsgált gének transzkripciójára és a karotinoid-termelésre. a - szárazanyagtartalomra vonatkoztatott karotinoid-tartalom, b - szárazanyagtartalom $1 \mathrm{~g}$ nedvesanyag tömegben, c - kontrollnak az MS12 1\% glükóz koncentrációjú táptalajon nevelt micéliumából izolált RNS-ből átírt cDNS-t vettük. A csillaggal jelzett izoprén gének gpdl promóter és terminális régiók szabályozása alatt állnak. 
A transzformánsokból több monosporangiális telepet izoláltunk, majd több telepből izolált RNS-ből átírt cDNS mintából mértük a relatív transzkripciós szinteket. Minden esetben kontroll kísérletekben vizsgáltuk, hogy a tisztított RNS minták DNáz kezelés után valóban mentesek-e a DNS szennyeződéstől. A megemelt gén-kópiaszámok megnövekedett transzkripciós szinteket eredményeztek a transzformánsokban, ugyanakkor a plazmid kópiaszám fluktuációja a relatív transzkripciós szintek ingadozását is eredményezte. A gpdl promóter régió szabályozása alá helyezett gének transzkripcióját különböző glükóz koncentráción nevelt tenyészetekből tisztított RNS-ből is lemértük, ahol az 1\% glükóztartalmú táptalajon nevelt MS12 törzset használtuk kontrollként. A kontrollhoz viszonyítva szignifikáns növekedést tapasztaltunk a gének transzkripciójában 2,5\% glükóztartalmú táptalajon nevelve, ugyanakkor az 5\% glükóztartalmú táptalajon történő nevelés a 2,5\% glükózhoz képest már nem eredményezett változást, sőt néhány esetben még csökkentek is a mért transzkripciós szintek (5. táblázat). Ha azonban figyelembe vesszük, hogy a glükóz koncentráció fokozásával csökkent a nemtranszformált MS12 törzs három izoprén génjének transzkripciós szintje, és azonos glükóz koncentrációjú táptalajon nevelt transzformáns és kontroll MS12 törzseket hasonlítunk össze, akkor láthatóvá válik az 5\% glükóz koncentrációjú táptalajon is a transzkripciós szintek növekedése. Mértük a transzkripciós szinteket 1,5 és 4 napig nevelt transzformáns tenyészetek micéliumából izolált RNS-ből is. A gpdl szabályozó régióit hordozó vektorral transzformált törzsek esetében tapasztaltunk jelentős különbséget: 1,5 nap után a túlmüködtetett izoprén gének magasabb expressziós szintet mutattak, mint 4 nap után, míg a $c r t W$ gén esetében ennek a fordítottját mértük, vagyis 4 nap után mértünk magasabb expressziós szintet minden transzformáns esetében.

\section{A karotintartalom elemzése}

A transzformánsok által termelt karotinoidok mennyiségét fotometriás, valamint HPLC mérésekkel határoztuk meg, míg az egyes karotinoidok arányát TLC és HPLC analízissel vizsgáltuk. A karotinoidok termelésének mértékét a géndózis-hatás alapján sikerült fokoznunk. Mind a TLC, mind a HPLC vizsgálatok igazolták, hogy az izoprén bioszintézis út gének túlmüködtetése nem változtatta meg a karotinoid-összetételt, vagyis ugyanazon karotinféleségek termelődtek, mint az MS12 törzsben (legnagyobb mennyiségben $\beta$-karotin, $\gamma$-karotin, likopin, $\beta$-kriptoxantin és zeaxantin). Az eredmény nem meglepő, hiszen új gént nem vittünk be. Ugyanakkor az egyes transzformánsokban és kotranszformánsokban az összkarotinoid mennyisége jelentősen megnőtt (6. táblázat, 26. és 27. ábra). Ez a növekedés jelentősebb mértékü volt azoknál a transzformánsoknál, 
amelyek a gpdl promóter és terminális régiókkal összeépített izoprén géneket hordozták (27. ábra).

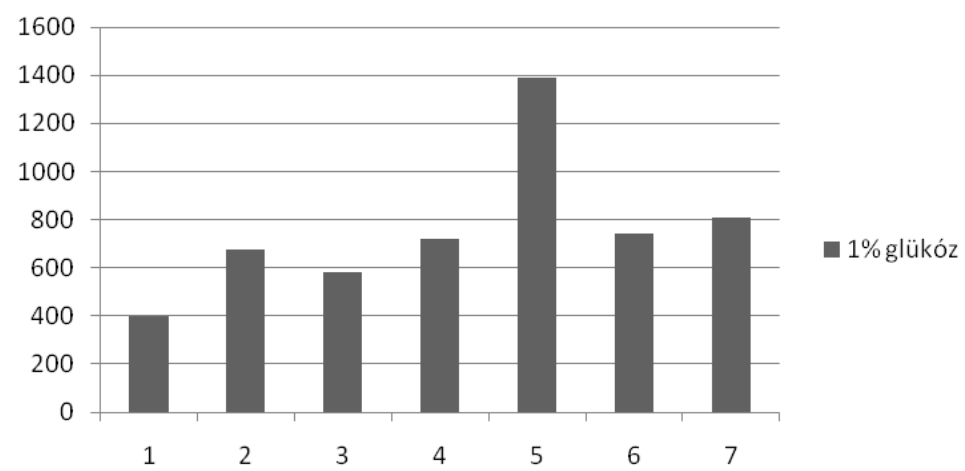

26. ábra. Az egyes transzformánsok által termelt, szárazanyagtartalomra vonatkoztatott átlagos karotinoid mennyiségek ( $\mu \mathrm{g} / \mathrm{g})$. 1: MS12, 2: MS12+pCA10 (ipi), 3: MS12+pAVB160 (isoA), 4: MS12+pCA6 ( $a r G)$, 5: MS12+pCA10; pAVB160 (ipi; isoA), 6: MS12+pCA10; pAVB161 (ipi; carG), 7: MS12+pAVB160; pCA6 (isoA; carG).
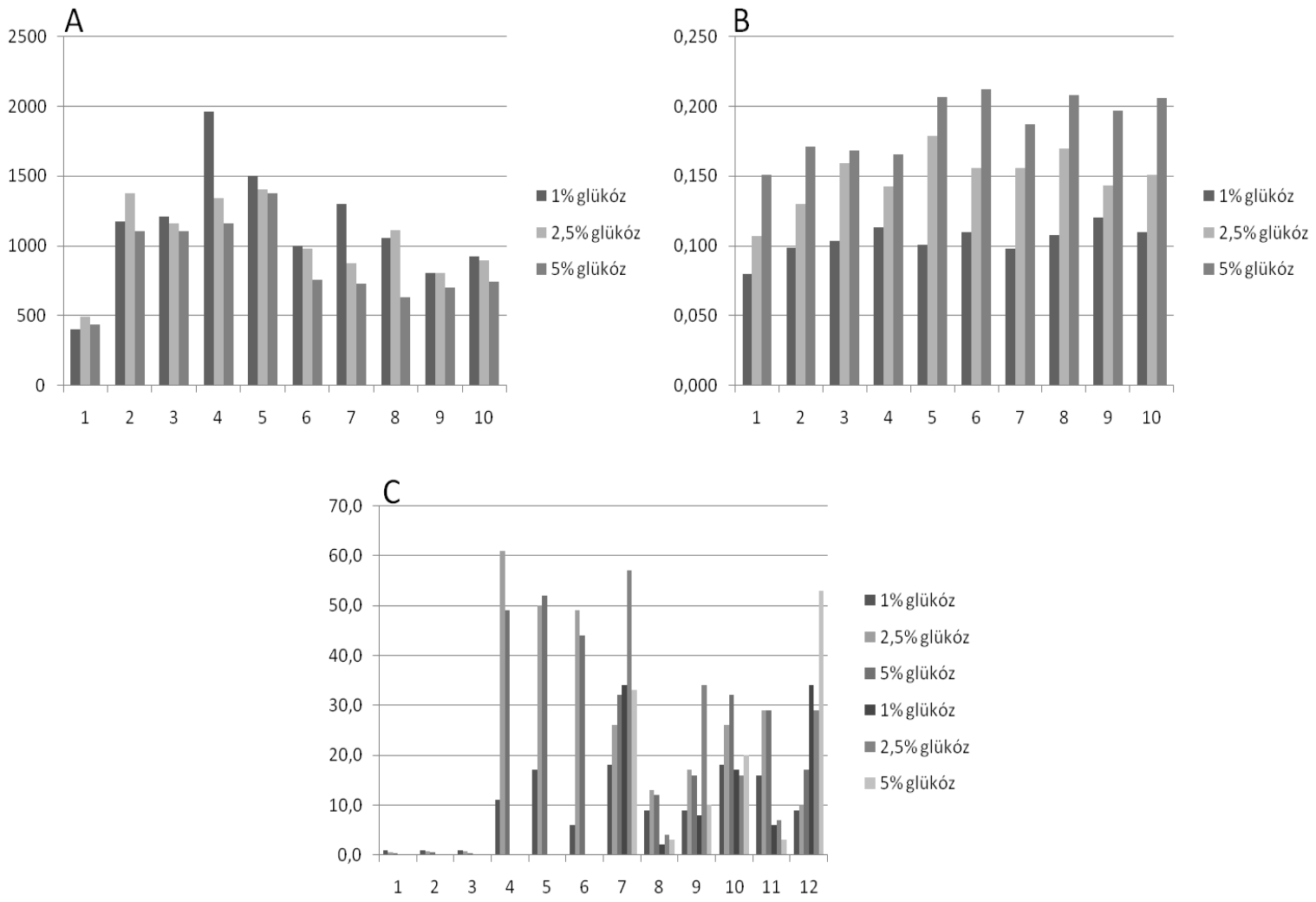

27. ábra. A termelt karotin mennyiségeket, a szárazsúly növekedést és a relatív transzkripciós szinteket ábrázoló diagramok. A minták sorrendje mindhárom panel esetében azonos: 1: MS12, 2: MS12+pPT85 (ipi), 3: MS12+pPT83 (isoA), 4: MS12+pPT84 (carG), 5: MS12+pPT83; pPT85 (isoA; ipi), 6: MS12+pPT82; pPT87 (ipi; carG), 7: MS12+pPT84; pPT86 (carG; isoA), 8: MS12+pPT82; pPT51 (ipi; crtW), 9: MS12+pPT83; pPT51 (isoA; $c r t W), 10:$ MS12+pPT84; pPT51 (carG; $c r t W)$.

A: Szárazanyag tömegre vonatkoztatott karotinoid-tartalom $(\mu \mathrm{g} / \mathrm{g})$

B: Szárazanyag tömeg $1 \mathrm{~g}$ nedvesanyagban $(\mathrm{g})$

C: A glükóz koncentráció fokozásának hatása a relatív transzkripciós szintekre. 


\begin{tabular}{|c|c|c|c|c|c|c|c|c|c|}
\hline Törzs & Likopin & $\beta$-karotin & $\gamma$-karotin & $\beta$-kriptoxantin & Zeaxantin & Kantaxantin & Ehinenon & Asztaxantin & Összkarotinoid \\
\hline $\begin{array}{c}\text { MS12 } \\
\text { MS12+pAVB107 (leuA) } \\
\text { MS12+pEPM9 (pyrG) }\end{array}$ & $\begin{array}{l}6 \pm 2(2) \\
5 \pm 2(1) \\
6 \pm 2(2)\end{array}$ & $\begin{array}{l}259 \pm 13(65) \\
255 \pm 10(63) \\
232 \pm 11(63)\end{array}$ & $\begin{array}{l}14 \pm 1(4) \\
13 \pm 1(3) \\
12 \pm 1(3)\end{array}$ & $\begin{array}{l}29 \pm 3(7) \\
31 \pm 3(8) \\
27 \pm 2(7)\end{array}$ & $\begin{array}{l}6 \pm 3(2) \\
6 \pm 2(2) \\
5 \pm 2(1)\end{array}$ & $\begin{array}{l}- \\
- \\
-\end{array}$ & $\begin{array}{l}- \\
- \\
-\end{array}$ & $\begin{array}{l}- \\
- \\
-\end{array}$ & $\begin{array}{l}399 \pm 27 \\
408 \pm 16 \\
370 \pm 18\end{array}$ \\
\hline $\begin{array}{c}\text { MS12+pCA10 (ipi) } \\
\text { MS12+pAVB160 (isoA) } \\
\text { MS12+pCA6 (carG) } \\
\text { MS12+pCA10; pAVB160 (ipi; isoA) } \\
\text { MS12+pCA10; pAVB161 (ipi; carG) } \\
\text { MS12+pAVB160; pCA6 (isoA; carG) }\end{array}$ & $\begin{array}{l}20 \pm 3(3) \\
15 \pm 3(3) \\
24 \pm 3(3) \\
39 \pm 4(3) \\
20 \pm 3(3) \\
13 \pm 2(2)\end{array}$ & $\mid \begin{array}{c}452 \pm 170(67) \\
369 \pm 85(63) \\
485 \pm 78(68) \\
881 \pm 221(63) \\
452 \pm 91(61) \\
463 \pm 87(57)\end{array}$ & $\begin{array}{l}21 \pm 2(3) \\
16 \pm 3(3) \\
19 \pm 4(3) \\
21 \pm 4(2) \\
15 \pm 1(2) \\
25 \pm 4(3)\end{array}$ & $\begin{array}{l}28 \pm 5(4) \\
23 \pm 2(4) \\
27 \pm 3(4) \\
46 \pm 4(3) \\
24 \pm 5(3) \\
37 \pm 5(5)\end{array}$ & $\begin{array}{l}9 \pm 2(1) \\
5 \pm 2(1) \\
9 \pm 2(1) \\
9 \pm 1(1) \\
5 \pm 2(1) \\
6 \pm 1(1)\end{array}$ & $\begin{array}{l}- \\
- \\
- \\
- \\
- \\
-\end{array}$ & $\begin{array}{l}- \\
- \\
- \\
- \\
- \\
-\end{array}$ & $\begin{array}{l}- \\
- \\
- \\
- \\
-\end{array}$ & $\begin{aligned} 674 & \pm 230 \\
584 & \pm 126 \\
718 & \pm 110 \\
1392 & \pm 396 \\
745 & \pm 149 \\
808 & \pm 148\end{aligned}$ \\
\hline $\begin{array}{c}\text { MS12+pPT85 }\left(i p i^{*}\right) \\
\text { MS12+pPT83 }\left(i s o A^{*}\right) \\
\text { MS12+pPT84 }\left(\text { carG }^{*}\right) \\
\text { MS12+pPT85; pPT83 }\left(i p i^{*} ; i s o A^{*}\right) \\
\text { MS12+pPT85; pPT84 }\left(\text { ipi }^{*} ; \text { carG }^{*}\right) \\
\text { MS12+pPT86; pPT84 }\left(\text { iso }^{*} ; \text { carG }^{*}\right)\end{array}$ & $\begin{array}{l}31 \pm 2(3) \\
36 \pm 5(3) \\
54 \pm 8(3) \\
34 \pm 7(2) \\
29 \pm 5(3) \\
35 \pm 6(3)\end{array}$ & $\left|\begin{array}{c|}770 \pm 154(65) \\
805 \pm 54(67) \\
1327 \pm 274(68) \\
894 \pm 93(59) \\
630 \pm 114(63) \\
779 \pm 261(60)\end{array}\right|$ & $\begin{array}{l}29 \pm 4(3) \\
36 \pm 3(3) \\
51 \pm 5(3) \\
23 \pm 3(2) \\
29 \pm 5(3) \\
43 \pm 2(3)\end{array}$ & $\begin{array}{l}47 \pm 6(4) \\
50 \pm 6(4) \\
77 \pm 3(4) \\
66 \pm 4(4) \\
37 \pm 8(4) \\
51 \pm 8(4)\end{array}$ & $\mid \begin{array}{c}11 \pm 2(1) \\
14 \pm 5(1) \\
25 \pm 6(1) \\
11 \pm 3(1) \\
8 \pm 3(1) \\
13 \pm 4(1)\end{array}$ & $\begin{array}{l}- \\
- \\
- \\
- \\
- \\
-\end{array}$ & $\begin{array}{l}- \\
- \\
- \\
- \\
- \\
-\end{array}$ & $\begin{array}{l}- \\
- \\
- \\
- \\
- \\
-\end{array}$ & $\begin{array}{c}1177 \pm 218 \\
1209 \pm 81 \\
1959 \pm 389 \\
1504 \pm 141 \\
1004 \pm 180 \\
1298 \pm 350\end{array}$ \\
\hline 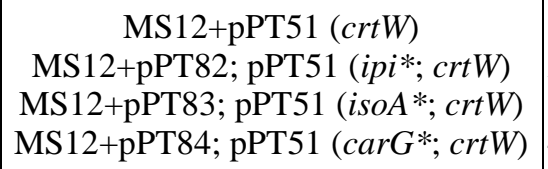 & $\begin{array}{c}5 \pm 2(1) \\
24 \pm 3(2) \\
17 \pm 3(2) \\
41 \pm 7(5)\end{array} \mid$ & \begin{tabular}{|c|}
$268 \pm 13(56)$ \\
$513 \pm 61(49)$ \\
$530 \pm 22(66)$ \\
$366 \pm 101(40)$
\end{tabular} & $\begin{array}{c}17 \pm 4(4) \\
74 \pm 8(7) \\
33 \pm 4(4) \\
69 \pm 12(8)\end{array}$ & $\begin{array}{l}35 \pm 2(7) \\
22 \pm 3(2) \\
24 \pm 3(3) \\
15 \pm 2(2)\end{array}$ & $\mid \begin{array}{c}1 \pm 1(0,2) \\
5 \pm 1(0,4) \\
6 \pm 2(1) \\
2 \pm 1(0,3)\end{array}$ & $\begin{array}{l}10 \pm 2(2) \\
65 \pm 7(6) \\
4 \pm 1(0,4) \\
42 \pm 5(5)\end{array}$ & $\begin{array}{c}11 \pm 3(2) \\
108 \pm 15(10) \\
5 \pm 2(1) \\
146 \pm 8(16)\end{array}$ & $\begin{array}{c}3 \pm 2(1) \\
1 \pm 1(0,1) \\
1 \pm 1(0,2) \\
2 \pm 1(0,2)\end{array}$ & $\begin{array}{c}478 \pm 28 \\
1053 \pm 98 \\
807 \pm 35 \\
924 \pm 146\end{array}$ \\
\hline
\end{tabular}

6. táblázat. Az izoprén bioszintézis génekkel transzformált törzsek karotinoid-tartalma és összetétele. A karotinoid mennyiségek $\mu \mathrm{g} / \mathrm{g}$ szárazanyagtartalomra vonatkoztatva vannak feltüntetve. Zárójelben az egyes karotinoidok százalékos aránya látható. A csillaggal jelölt izoprén gének gpdl promóter és terminális régiók szabályozása alatt állnak. 
Meg kell jegyeznünk, hogy a relatív plazmid kópiaszámmal és a relatív transzkripciós szintekkel együtt a karotinoid-termelés is folyamatosan ingadozott. Ennek ellenére tehető néhány általános megjegyzés. Egy plazmiddal történő transzformáció

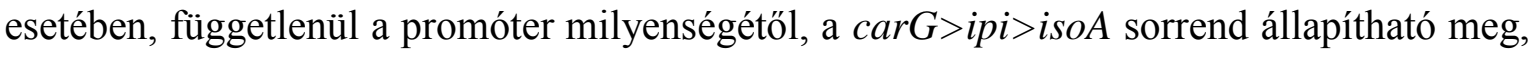
annak függvényében, hogy mely gén túlmüködtetése okozta a legnagyobb növekedést a karotinoid termelésben. Ez valószínüleg annak köszönhetö, hogy a GGPP nem csupán az izoprén bioszintézis út végterméke, hanem egyben a karotinoid-specifikus út kezdő vegyülete is. Ezt megerösíti, hogy a carG gén is, a karotinoid-specifikus génekhez (carRP, carB) hasonlóan, kék fény általi szabályozás alatt áll (Velayos és mtsi. 2003, Silva és mtsi. 2006), valamint baktériumokban a GGPP szintázt kódoló gén (crtE) a karotinoid génklaszter része (Sandmann 1997). A GGPP szintáz túlmüködtetése megnövelte a karotinoid-termelést heterológ géneket hordozó és ez által karotintermelővé vált $E$. coli törzsben (Wang és mtsi. 1998). Az ipi gén túlmüködtetése szintén nagy karotinoidtermelés növekedést okozott $M$. circinelloides-ben. Mivel az IPP izomeráz katalizálja az izoprén bioszintézis út első lépését, ezért nem meglepő, hogy a gén túlmüködtetése minden izoprén származék, így a karotinoidok mennyiségének növekedését is okozhatja (Lee és Schmidt-Dannert 2002, Das és mtsi. 2007). Hasonló karotinoid-tartalom növekedést mértek heterológ IPP izomeráz $E$. coli-ban történő túlmüködtetése révén Kajiwara és mtsi. (1997), Misawa és Shimada (1998), Albrecht és mtsi. (1999). Ugyanakkor Misawa és Shimada (1998) C. utilisben nem tapasztalt hasonló termelésnövekedést. RodríguezVillalón és mtsi. (2008) az IPP és a DMAPP, valamint ezek prekurzor vegyületeinek mennyiségét növelve drámaian fokozták a likopin termelést karotintermelő mutáns $E$. coli törzsben, ugyanakkor $X$. dendrorhous-ban endogén IPP izomeráz gpd szabályozó régiók alatt csökkentette a karotinoid termelődést (Visser és mtsi. 2005). Kotranszformánsok esetében, függetlenül a promóter milyenségétől a következő sorrendet tudtuk felállítani, annak függvényében, hogy mely génkombináció okozta a legnagyobb növekedést a karotinoid termelésben: ipi+isoA>isoA+carG>ipi+carG. Egyes transzformánsokban a karotintermelés mértéke az MS12 törzshöz képest három-négyszeresére nőtt. Kontroll kísérletekkel igazoltuk, hogy az auxotrófia komplementálása nem okoz változást a karotinoid termelésben.

A glükóz koncentráció fokozása indukálja a gpdl gén expresszióját (Wolff és Arnau 2002, Larsen és mtsi. 2004). Az MS12 gpdl szabályozó régiókkal összeépített izoprén génekkel történő transzformációja ugyanakkor nem eredményezett a vártnak megfelelő változást a karotinoid termelésben, vagyis amikor a transzformánsokat 2,5 illetve 5\% glükóz koncentrációjú táptalajon neveltük a relatív transzkripciós szintek 
növekedése nem eredményezte a karotintartalom szárazanyag tömegre vonatkoztatott mennyiségének emelkedését. Úgy tűnik, hogy a transzformánsok elérték az általuk termelhető maximális karotinoid mennyiséget. A telepek fenotípusában azonban színintenzitásbeli változás volt megfigyelhető (28. ábra). A mérések során fény derült arra, hogy a glükóz koncentráció fokozása növeli az egységnyi nedvesanyag tömegben mérhető szárazanyagtartalmat, vagyis a biomasszát (ld. 5. táblázat). A szárazanyagtartalom emelkedése magyarázható azzal, hogy az izoprén gének magasabb expressziója egyéb izoprén-származékok, így szterolok, ubikinonok, prenilált proteinek mennyiségének növekedéséhez is vezet. Szczęsna-Antczak és mtsi. (2006) kimutatták, hogy a glükózzal, mint szénforrással kiegészített táptalaj megnöveli a lipidek és a karotinoidok termelődését M. circinelloides és $M$. racemosus tenyészetekben. Magasabb glükóz koncentráció ugyanakkor represszálhatja a karotinoid-bioszintézis géneket.

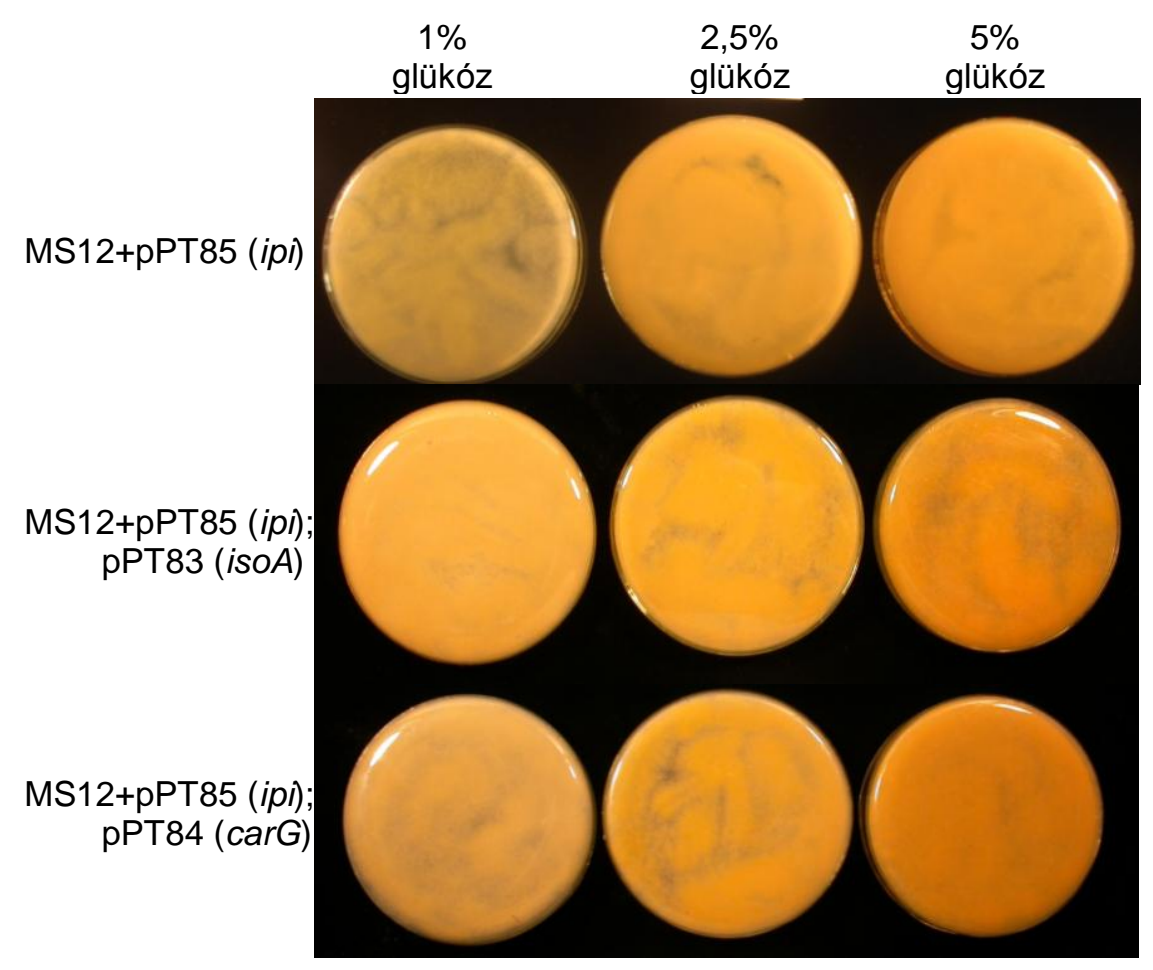

28. ábra. Néhány transzformáns törzs színintenzitás változása $1 \%, 2,5 \%$, valamint $5 \%$ glükóztartalmú táptalajon nevelve.

A korábbiakban már igazoltuk, hogy a $M$. circinelloides rendelkezik $\beta$-karotin hidroxiláz aktivitással (Papp és mtsi. 2006, Álvarez és mtsi. 2006). Annak érdekében, hogy fokozzuk a hidroxilált és ketolált xantofillok termelődését, az MS12 törzset a $\mathrm{crtW}$ gént hordozó pPT51 plazmiddal és valamely izoprén gént hordozó vektorral (pPT82-84) együtt transzformáltuk. A transzformánsok és azok színváltozása a 29. ábrán látható. A legtöbb xantofillt a carG-vel történő együttes transzformáció, ugyanakkor a legnagyobb 
összkarotinoid termelést az ipi-vel történő kotranszformáció eredményezte (ld. 6. táblázat és 30. ábra).

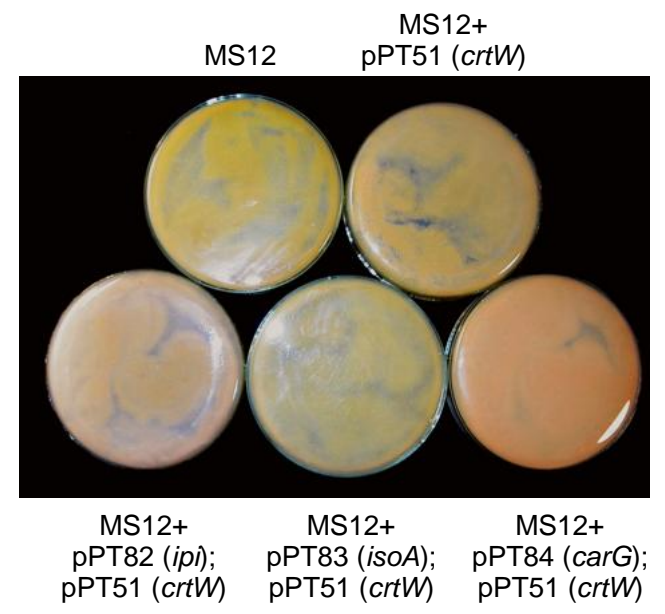

29. ábra. A pPT51 vektort hordozó transzformánsok és kotranszformánsok az MS12 törzzsel összehasonlítva.

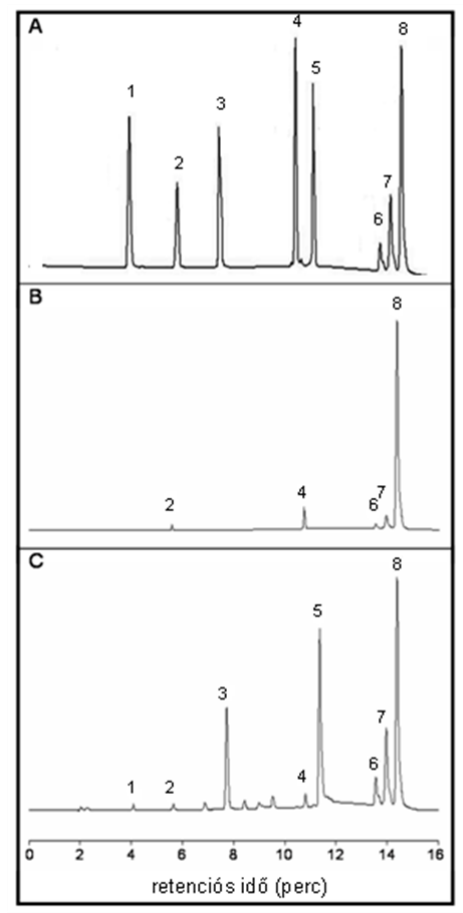

30. ábra. Karotinoid minták HPLC kromatogramja. A számok által jelölt karotinoidok: 1: asztaxantin, 2: zeaxantin, 3: kantaxantin, 4: $\beta$-kriptoxantin, 5: ehinenon, 6: likopin, 7: $\gamma$-karotin, 8: $\beta$-karotin.

A: Standardok

B: MS12 törzs

C: MS12+pPT84; pPT51 ( $c a r G ; c r t W)$ kotranszformáns törzs

Érdekes, hogy a pPT51 vektort önmagában hordozó mutáns törzs nagyobb mennyiségü xantofillt termelt, mint az isoA-val történő kotranszformációja esetén. Ezt az eredményt nehéz megmagyarázni, esetlegesen az FPP szintáz túlmüködtetése indirekt 
módon hat a $\beta$-karotin ketoláz aktivitására a szintézis szabályozásának megváltoztatásával. Egy másik magyarázat lehet a már korábban említett kompartmentalizáció hatása, vagyis az, hogy a különböző izoprénvázas vegyületek (a karotinoidok, ubikinonok és szteroidok, valamint a triacil-glicerolok) szintézise külön kompartmentekben zajlik, elkülönülö prekurzorokból (Kuzina és mtsi. 2006). Az asztaxantin mennyisége minden transzformáns esetében nagyon alacsony volt, valószínüleg a Mucor hidroxiláza nem vagy csak kis affinitással képes a kantaxantint szubsztrátként hasznosítani. A transzformánsok karotinoid termelését különbözö glükóz koncentrációjú táptalajon is megvizsgáltuk. A színintenzitás változása, valamint a TLC vizsgálatok alapján a glükóz koncentráció fokozása látszólag növelte a karotinoid-tartalmakat (31. ábra). Ezzel ellentétesen a szárazanyag tömegre vonatkoztatott karotinoid mennyiségek csökkenését, ugyanakkor az egységnyi micéliumtömegben mérhető szárazanyag tömeg növekedését mértük (ld. 5. táblázat).

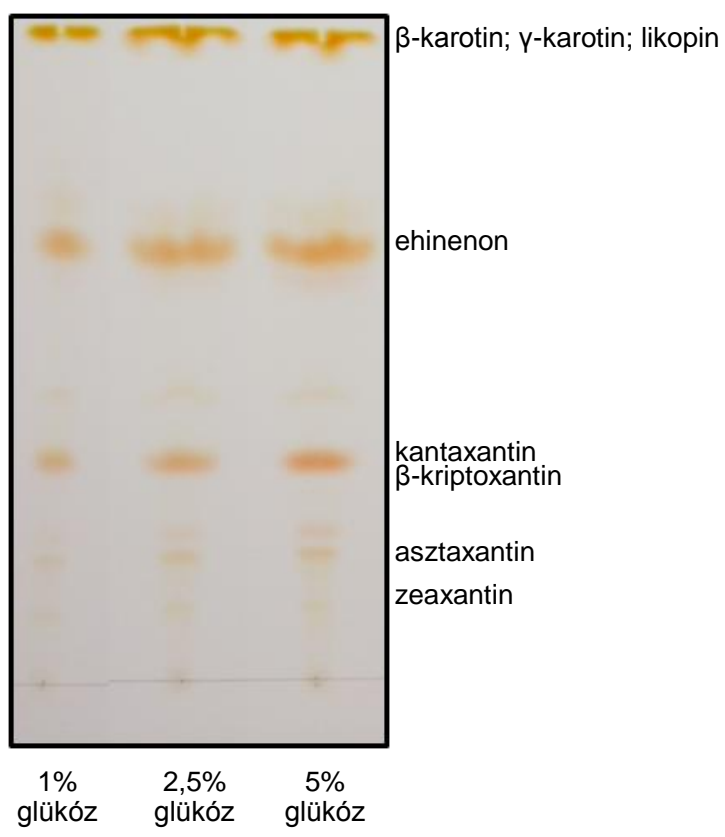

31. ábra. Az MS12+pPT84 ( $c a r G)$; pPT51 ( $c r t W)$ kotranszformáns törzs karotinoid termelésének TLC analízise különböző glükóz koncentrációjú táptalajon. A karotinoid mintákat azonos tömegü micéliumból nyertük.

6.3. A crtW gén integrációja a Mucor genomba (Csernetics és mtsi. 2011b, Papp és mtsi. 2011)

A korábbi kutatások tapasztalatai szerint a járomspórás gombákba bejuttatott plazmidokat a gombák autoreplikatív módon hordozzák, anélkül, hogy a bejuttatott DNS (vagy annak egy része) integrálódna a genomba. Ha a bejuttatott gének integrálódnának a gomba genomjába, elkerülhető lenne a transzformánsok plazmid kópiaszámának és ezzel párhuzamosan a karotinoid termelésének ingadozása is. Az integráció több módszerrel is 
kikényszeríthető, egyik lehetséges módszer, ha olyan lineáris DNS molekulával transzformálunk, amely nem képes cirkularizálódni, viszont tartalmaz a homológ rekombinációt irányító, az integrálandó szekvenciát közrefogó homológ szakaszokat. További megoldás lehet a restrikciós enzim-közvetített integráció, azonban ezt eddig sikertelenül próbálták járomspórás gombáknál, illetve az Agrobacterium tumefaciensközvetített transzformáció, melyet már több járomspórás gombafajnál is sikeresen alkalmaztak (ld. Irodalmi áttekintés, 3.6. fejezet). Az integráció megvalósításához különböző vektorokat szerkesztettünk és mindegyikkel elvégeztük a transzformációt.

\subsubsection{Expressziós vektorok építése és transzformációs kísérletek}

Minden vektor alapja a már korábban is alkalmazott gpdl promóter és terminális régiók közé épített $c r t W$ gén volt, azaz a pPT51 plazmid. Szelekciós markerként ezúttal is a pyrG vagy leuA gént használtuk.

\section{Integráció kettős homológ rekombinációval}

A pCA8 vektorban a kettős rekombinációt biztosító homológ szakaszként a leuA gént, mely egyúttal szelekciós markerként is szolgált, és az attól 5' irányban elhelyezkedő szekvenciát használtuk, és ezek közé építettük a $g p d P$-crtW-gpdT kazettát. Első lépésként a pPT51 plazmidból a Mucor leuA gént XbaI enzim segítségével kivágtuk, a fennmaradt szakaszt pedig önmagával összeligáltuk (pPT51RE). A leuA gént és határoló szekvenciáit a pAVB107 plazmidból XbaI és PstI restrikciós endonukleázok segítségével kivágtuk és a pUC18 vektor azonos hasítóhelyei közé építettük (pCA7 plazmid). A továbbiakban a pCA7 SmaI és ScaI helyei közé beépítettük a pPT51RE NaeI és ScaI hasítóhelyei közötti, gpd1P-crtW-gpdT kazettát hordozó szakaszt. Az integratív transzformációhoz a pCA8 plazmidból kivágtuk a homológ szakaszokkal határolt ClaI-AatII fragmentumot (pCA8/lf, 32. ábra) és ezzel a lineáris fragmentummal végeztük a PEG-közvetített protoplaszt transzformációt (MS12+pCA81f transzformáns törzsek).

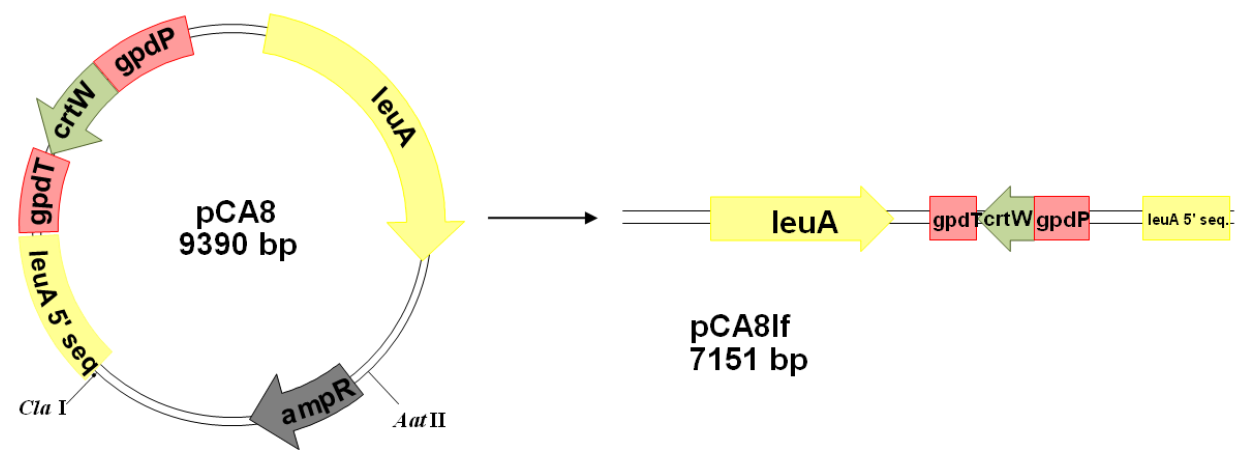

32. ábra. A crtW gén integrációjához épített pCA8 vektor és a kivágott pCA8/lf lineáris fragmentum. 
Egy másik konstrukciót is készítettünk (pCA9), ahol a gpdP-crtW-gpdT kazettát, a pyrG szelekciós markerrel együtt, a Mucor genomból amplifikált $18 \mathrm{~S}$ és $28 \mathrm{~S}$ rDNS szekvenciák közé építettük. Ez utóbbi szakaszok szolgáltak homológ szekvenciaként a kettős rekombináció irányításához. Ehhez a $18 \mathrm{~S}$ rDNS szakaszt PCR-rel felszaporítottuk a RIB1 és RIB2 primerekkel, amelyek SacI, illetve KpnI hasítóhelyeket tartalmaztak a végükön, majd ezek segítségével pUC18 vektorba a megfelelő restrikciós hasítóhelyek közé építettük. Ezzel párhuzamosan a 28S rDNS egy szakaszát is felszaporítottuk, ehhez a RIB3 és RIB5 primereket használtuk, melyek a végükön BamHI és SalI hasítóhelyeket hordoztak. A terméket a 18S rDNS-pUC18 konstrukcióba építettük a megfelelö hasítóhelyek közé. Így nyertük a pCA1828 vektort (33. ábra). A pPT51 vektorból XbaI és PstI restrikciós endonukleázokkal kivágtuk a gpdl szabályzó régiókkal összeépített $c r t W$ gént, melyet azonos hasítóhelyek közé a pEPM901 plazmidba építettünk (ez utóbbi hordozza az uracil auxotrófia komplementálásáért felelős pyrG gént). Ebböl a vektorból ClaI és KpnI restrikciós enzimekkel kihasítottuk a $g p d 1 P$-crtW-gpdlT kazettát és a pyrG gént hordozó fragmentumot, amit a pCA1828 vektor azonos hasítóhelyei közé építettünk. Így nyertük a pCA9 vektort (34. ábra), amelyet a transzformációhoz AatII és NheI enzimekkel hasítva linearizáltunk (pCA9lf, 34. ábra). A pCA9lf fragmentummal a szokásos módon transzformáltuk a $M$. circinelloides MS12 törzsét (MS12+pCA9lf transzformáns törzsek).

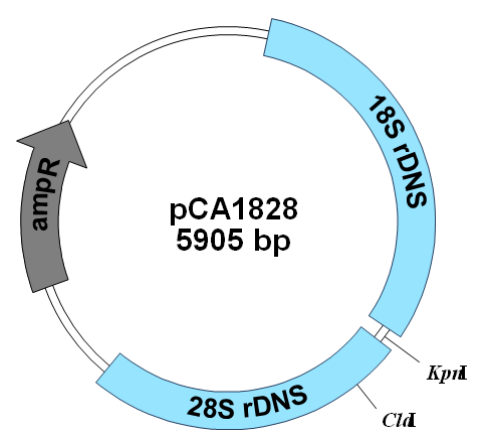

33. ábra. A PCR-rel amplifikált $18 \mathrm{~S}$ és $28 \mathrm{~S}$ riboszómális RNS génszakaszok ( $r D N S)$ pUC18 klónozó vektorba építve.

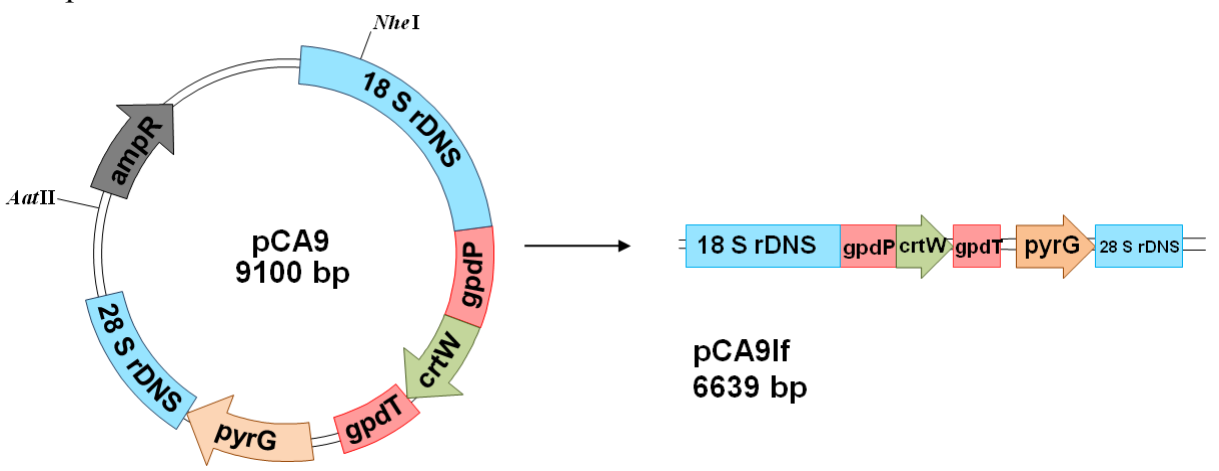

34. ábra. A crtW gén integrációjához épített pCA9 vektor és a kivágott pCA9/lf lineáris fragmentum. 


\section{Integráció restrikciós enzim mediált integrációval (REMI)}

A transzformációhoz a már korábban említett pPT51, pCA8 és pCA9 vektorokat használtuk, melyeket különböző restrikciós endonukleáz enzimpárokkal hasítottunk, az alábbiak szerint: pCA8/SalI-SacI; pCA9/ClaI-KpnI; pCA9/PstI-KpnI; pPT51/SalI-ScaI; pPT51/NaeI-NdeI; pPT51/NaeI-ClaI (35. ábra). Az így nyert lineáris fragmentumokkal transzformáltuk az MS12 törzset, úgy, hogy a protoplasztokhoz a transzformáló DNS mellett a linearizáláshoz használt restrikciós endonukleázokat is hozzáadtuk, hogy azok a magokba jutva feldarabolják a genomi DNS-t. Íly módon az újbóli összerendeződés során megtörténhet a transzformáló DNS beépülése a genomba (ld. Irodalmi áttekintés, 10. ábra). A transzformánsokat az előbb felsoroltaknak megfelelően a következőkképen neveztük el MS12+pCA8R, MS12+pCA9R1, MS12+pCA9R2, MS12+pPT51R1, MS12+pPT51R2 és MS12+pPT51R3, ahol a számozás ugyanazon lineáris fragmentum különböző restrikciós endonukleázokkal történő hasítását jelzi.
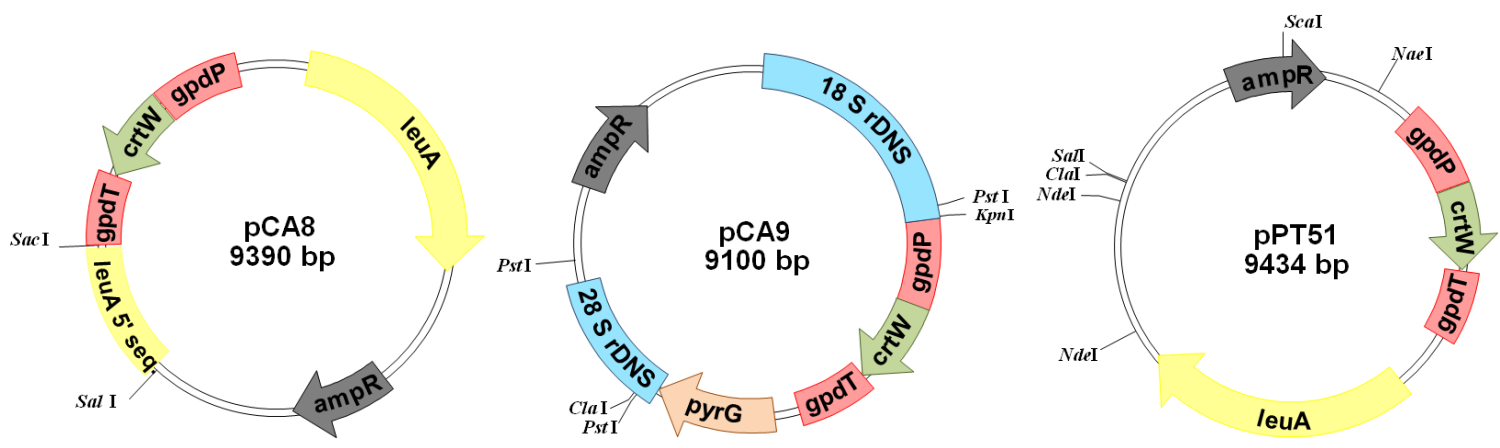

35. ábra. A REMI-hez különböző restrikciós endonukleáz enzimpárokkal emésztett pCA8, pCA9 és pPT51 vektorok.

\section{Integráció Agrobacterium tumefaciens-mediált transzformációval (ATMT)}

A pPK2-crtW vektort a Covert-től kapott pPK2-ből kiindulva építettük, ahol az eredeti, hygromycin rezisztenciát biztosító gént tartalmazó $(h p h)$ kazettát kicseréltük a gpd1P-crtW-gpd1T kazettára, valamint a pyrG szelekciós génre PstI, KpnI és SacI restrikciós endonukleázok segítségével (36. ábra). A transzformációt az Anyagok és módszerek fejezetben leírtak szerint végeztük, a nyert törzseket MS12+pPK2W-nek neveztük el.

\subsubsection{Az integratív transzformánsok elemzése}

Mindegyik felsorolt módszerrel és vektorkonstrukcióval elvégeztük a transzformációt és mindhárom transzformációs módszerrel kaptunk transzformáns telepeket. A REMI kísérletek is eredményesek voltak, egyedül a pCA9 plazmidból kivágott lineáris fragmentummal végzett REMI nem eredményezett transzformáns 
telepeket. Ezzel kutatócsoportunknak elöször sikerült járomspórás gombát REMI módszerrel transzformálni. A kísérletek során nyert transzformánsokat, azok genotípusára és fenotípusára vonatkozó főbb jellemzőket a 4. és az 5. mellékletben foglaltuk össze.

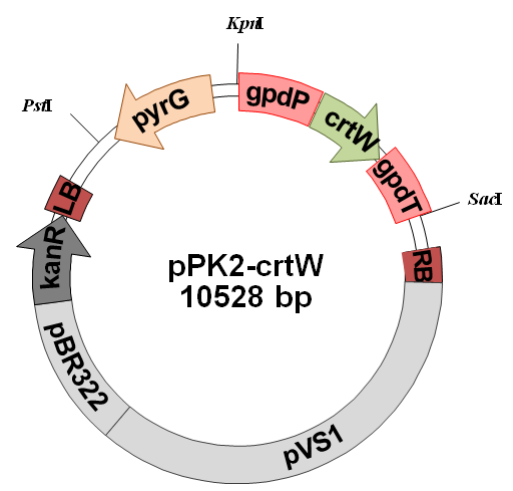

36. ábra. Az ATMT-hez szerkesztett pPK2-crtW bináris vektor.

\section{Transzformációs gyakoriság}

Lineáris fragmentumokkal végzett PEG-mediált protoplaszt transzformáció esetében a transzformáció során alkalmazott körülmények optimalizálása után is alacsony maradt a transzformációs hatékonyság: $1-4$ telep $/ 5 \times 10^{5}$ protoplaszt volt, $10-15 \mu \mathrm{g}$ lineáris transzformáló DNS-t alkalmazva. A transzformáló DNS koncentrációjának emelése nem fokozta a transzformációs hatékonyságot; természetesen a DNS koncentráció és a protoplasztok számának egyidejü emelése növelheti a transzformációs gyakoriságot. A transzformáns telepek megjelenése lassúbb volt, mint cirkuláris plazmid alkalmazása esetén (kb. 1 hét). A REMI során két különböző restrikciós endonukleázt alkalmaztunk (30-30 U mennyiségben) a recirkularizáció elkerüléséhez, Maier és Schäfer (1999) publikációjában közölt adatok alapján. A transzformáció során az Anyagok és módszerek fejezetben (5.6.15.) leírt, 32-35 ${ }^{\circ} \mathrm{C}$-on történő 1,5 órás inkubációt alkalmaztuk a transzformációs gyakoriság fokozása érdekében. Az inkubációs hőmérsékletet és időt előzetesen optimalizáltuk a Mucor protoplasztokra.

Az ATMT módszer esetében némileg magasabb volt a transzformációs gyakoriság (3-8 telep/transzformáció), függetlenül attól, hogy spórákat vagy protoplasztokat transzformáltunk. Michielse és mtsi. (2004) R. oryzae esetében csak protoplasztok sikeres transzformációját írták le, spórákat sikertelenül próbáltak ezzel a módszerrel transzformálni. Ez a különböző járomspórás gombafajok spóráinak eltérő sejtfalfelépítéséből eredhet. A folyékony IM tápoldatban történő együtt-tenyésztés némileg nagyobb transzformációs gyakoriságot eredményezett, mint a szilárd táptalajon történő együtt-tenyésztés, de a különbség olyan kicsi volt, hogy valószínűleg csak a kísérleti 
rendszer pontatlanságából ered, minthogy valóban a két módszer közötti különbségből adódna. Az együtt-tenyésztési hőmérsékletnek megfelelőnek kellett lennie mind a vir gének aktivációjához, mind a $M$. circinelloides növekedéséhez; az általunk alkalmazott 28 ${ }^{\circ} \mathrm{C}$ mindkét kritériumnak megfelelt. Az együtt-tenyésztési idő tekintetében a 2-3 nap bizonyult optimálisnak. A szelektív táptalajra helyezett celofánkorongokon 5-6 nap után jelentek meg a transzformáns telepek. Fontos megemlíteni, hogy a celofánkorongot teljesen beborító baktériumpázsit elpusztítása nem volt könnyü, a transzformánsokat ezért többször átoltottuk cefotaxim tartalmú táptalajra.

\section{$\underline{\text { Az integratív transzformánsok molekuláris elemzése }}$}

PCR segítségével igazoltuk, hogy a transzformáló DNS, illetve az általa hordozott crtW gén jelen van a háromféle módszerrel kapott transzformáns törzsekben. Southern hibridizációs kísérleteket végeztünk a transzformáló DNS Mucor genomba történő integrációjának bizonyításához. Az izolált DNS minták különböző restrikciós endonukleázokkal történő hasítása után végzett hibridizációval a legtöbb esetben sikerült igazolnunk a transzformáló DNS integrációját, mivel a transzformáló lineáris DNS-ből és a transzformánsokból tisztított DNS-ből eltérő méretü jeleket kaptunk, illetve egyazon DNS minta különböző restrikciós endonukleázokkal történő hasítása szintén eltérő méretü jeleket eredményezett (37. ábra). A hibridizációs mintázatok alapján feltünt, hogy nem csak az irányított integrációval, hanem a randomnak vélt REMI-vel és ATMT-vel nyert transzformánsok esetében is gyakran a genom egyazon (meghatározott) helyére történt az integráció, vagyis feltételezhetőek ún. „hotspot”-ok a genomban, azonban ezek szekvenciáját általában nem sikerült azonosítanunk. A vizsgálatok során kimutattuk, hogy az integráció általában egy kópiában történt, ugyanakkor esetenként a REMI és az ATMT többkópiás integrációt eredményezett. Az ATMT transzformációt a Nyilasi és mtsi. (2005) által is alkalmazott protokoll szerint végeztük, ahol a $h p h$ bakteriális gént integrálták a $M$. circinelloides genomjába és Southern hibridizációs kísérletek során egykópiás beépülést tapasztaltak. Michielse és mtsi. (2004) szintén egykópiás integrációt írtak le $R$. oryzae ATMT-vel történő transzformációja során. Rho és mtsi. (2001) Magnaporthe grisea esetében szintén egykópiás integrációt írtak le, ugyanakkor az együtt-tenyésztési idő növelésével többkópiás integrációt értek el, amit viszont Mullins és mtsi. (2001) Fusarium oxysporum esetében nem tudtak megismételni. Sullivan és mtsi. (2002) Beauveria dermatiditis, Hanif és mtsi. (2002) pedig Suillus bovinus esetében írták le, hogy az Agrobacterium sejtek koncentrációjának növelése többkópiás integrációt eredményezett, míg Mullins és mtsi. (2001) F. oxysporumnál nem erre az eredményre jutottak. Maier és 
Schäfer (1999) kimutatták, hogy a REMI esetében általában egykópiás integráció történik. Transzformációs módszertől függetlenül több olyan transzformáns telepet izoláltunk, melyekből a nagyon alacsony kópiaszám miatt hibridizációval nem tudtuk vizsgálni a transzformáló DNS sorsát, Monfort és mtsi. (2003) kanamycin rezisztencián alapuló Rhizomucor miehei transzformációja során hasonló jelenséget tapasztaltak.

A

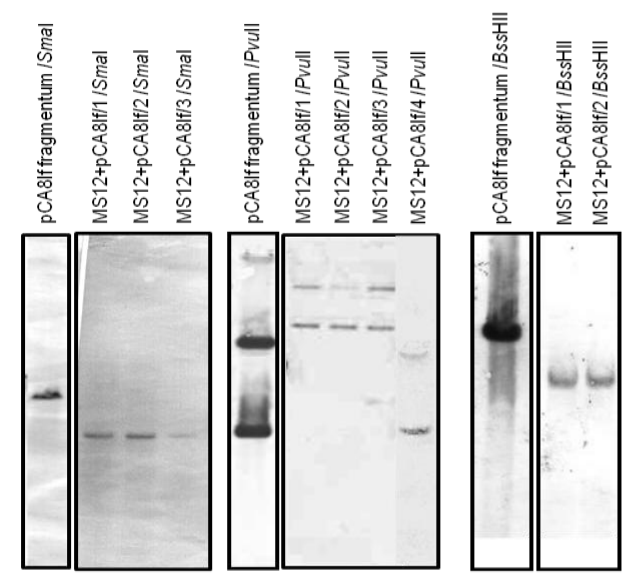

C

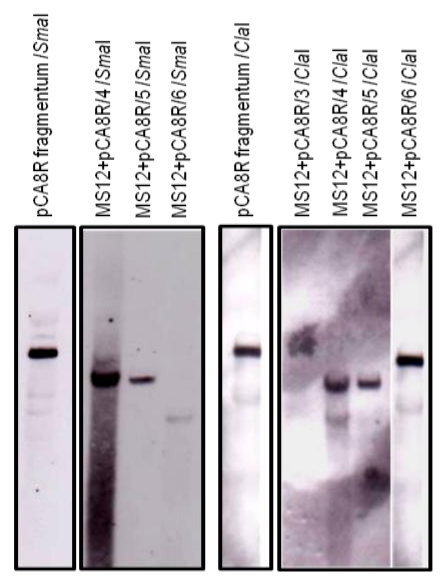

B

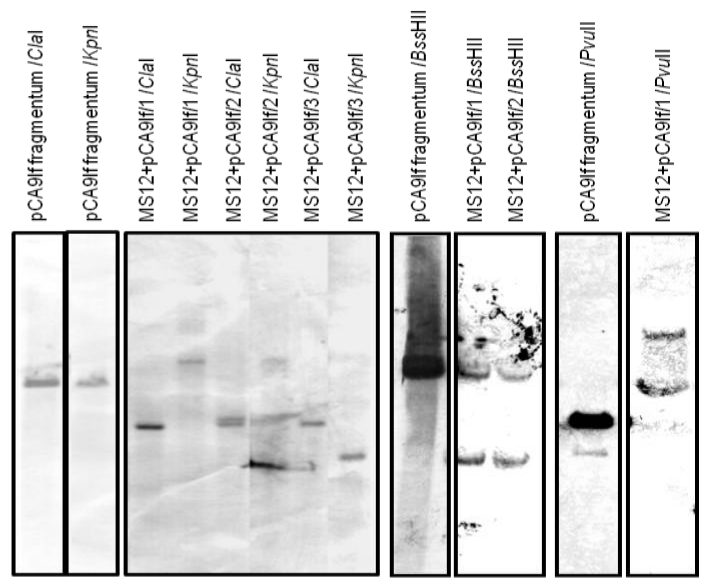

E

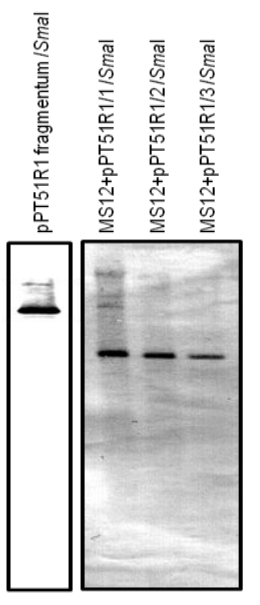

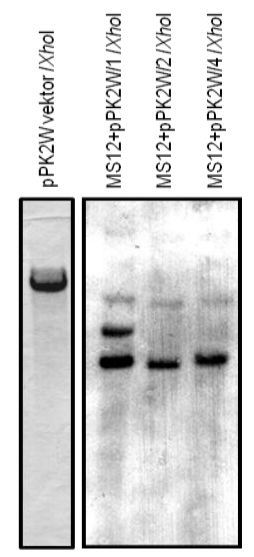

37. ábra. A $\operatorname{crtW}$ gén jelenlétének és integrációjának igazolása különböző integratív transzformánsokból tisztított DNS-ből Southern hibridizációs kísérletekkel, jelölt crtW génpróba segítségével. Az ábrán néhány kiragadott példa látható.

A: SmaI, PvuII és BssHII restrikciós endonukleázokkal emésztett pCA8lf fragmentummal transzformált MS12 transzformánsokból tisztított DNS hibridizációs mintázata.

B: ClaI, KpnI, BssHII és PvuII restrikciós endonukleázokkal emésztett pCA9lf fragmentummal transzformált MS12 transzformánsokból tisztított DNS hibridizációs mintázata.

C: SmaI, ClaI, BssHII és PvuII restrikciós endonukleázokkal emésztett pCA8R fragmentummal transzformált (REMI) MS12 transzformánsokból tisztított DNS hibridizációs mintázata.

D: SmaI restrikciós endonukleázzal emésztett pPT51R1 fragmentummal transzformált (REMI) MS12 transzformánsokból tisztított DNS hibridizációs mintázata.

E: XhoI restrikciós endonukleázzal emésztett pPK2W vektorral transzformált (ATMT) MS12 transzformánsokból tisztított DNS hibridizációs mintázata.

Inverz-PCR technika segítségével vizsgáltuk a bejuttatott DNS genomba történő integrációjának helyét. A tisztított DNS-t olyan restrikciós endonukleázokkal hasítottuk, amelyek felismerőhelyét a transzformáló DNS nem hordozta. Primereket terveztünk a 
transzformáló DNS két végére, úgy, hogy a feldarabolt genomi DNS fragmentumok önmagukkal történő ligálását követő PCR reakció segítségével meghatározhassuk a transzformáló DNS-t határoló genomi szakasz szekvenciáit (Triglia és mtsi. 1988, Ochman és mtsi. 1988).

A következő megállapításokat tettük:

MS12+pCA81f transzformánsok vizsgálata során az integráció az esetek többségében a $M$. circinelloides genom leuA génjébe történt, tehát valóban kettős homológ rekombináció általi irányított integrációt sikerült megvalósítanunk. Arnau és mtsi. (1991) leu` mutáns $M$. circinelloides törzs sikeres transzformációját írták le, ahol a leuA gén kettős homológ rekombinációval történő integrációjával a leucin auxotrófia komplementációját valósították meg. Arnau és Stroman (1993) szintén leírtak integrációt génkicserélődés útján, ahol szintén a leucin auxotrófiát komplementálták a leuA gén Mucor genom leuA lókuszbába történő integrációjával. Ugyanakkor egyes transzformánsok esetében az integráció randomnak bizonyult. Esetenként az inverz PCR során olyan fragmentumokat is izolálnunk, amelyek a vektorból eredő DNS szekvenciák között rövid genomi eredetủeket hordoztak, míg a crtW gént nem tartalmazták. Ezek feltehetően pontatlanul kivágódott, majd recirkularizálódott DNS darabokból származhatnak, amelyek extrakromoszómális elemként maradhattak fenn.

Az MS12+pCA91f transzformánsok esetében a Mucor genomból származó szekvenciákat tudtunk azonosítani, amelyek a várttal ellentétben nem a $18 \mathrm{~S}$ vagy $28 \mathrm{~S}$ riboszómális DNS régiókból származtak, tehát ez esetben az integráció ektopikusnak bizonyult. Arnau és Stroman (1993) nyolc M. circinelloides transzformáns törzs esetében igazolták, hogy előfordulhat mind additív integráció homológ és heterológ helyre, mind pedig génkicserélődés. $R$. miehei esetében Monfort és mtsi. (2003) rDNS szekvenciák segítségével integrációt tudtak elérni cirkuláris plazmid segítségével.

Az MS12+pCA8R transzformánsokkal végzett inverz-PCR kísérletek többféle szekvenálási eredményt szolgáltattak. Egyes esetekben a szekvenciák a Mucor genomban található leuA gén közeléből származtak, más adatok pedig átrendeződött plazmid és ismeretlen szekvenciarészleteket mutattak, amelyeket sem a vektorokból, sem a Mucor genom adatbázisból nem sikerült azonosítanunk. Ezek, valamint a Southern hibridizáció kísérletek eredményei azt igazolják, hogy néhány transzformánsban az integráció több kópiában random helyre történt, továbbá DNS átrendeződések is történtek. Természetesen az integráció helyét meghatározza az, hogy hol található a genomban az alkalmazott restrikciós endonukleázok által felismert nukleotidsorrend. Sweigard és mtsi. (1998) Magnaporthe grisea, illetve Lu és mtsi. (1994) Cochliobolus heterostrophus esetében 
kimutatták, hogy a REMI transzformáció során az integráció, a kromatin struktúra felépítésének köszönhetően, valójában nem teljesen random helyre történik. Ez abból adódik, hogy a transzkripció szempontjából aktívabb régió érzékenyebb a restrikciós hasításokra, mint a transzkripcionálisan inaktív, mivel a génexpresszióhoz relaxáltabb kromatin struktúra szükséges (Maier és Schäfer 1999).

MS12+pPT51R1 transzformáns törzseknél egyes esetekben rövid, a Mucor genomból származó DNS szekvenciák mellett az esetek többségében plazmid szekvenciákat tudtunk azonosítani. Más esetekben az egy transzformánsból származó kevert szekvenciák mind többkópiás integrációból, mind plazmid kivágódásból származhattak. Mindegyik REMI transzformáció során, függetlenül az alkalmazott lineáris fragmentumtól, megfigyeltünk olyan transzformánsokat, amelyekben a szekvenciaadatok alapján feltételezhetően ugyanazon, de nem homológ helyre történt az integráció.

MS12+pPK2W transzformánsok esetében az azonosíthatatlan és kevert szekvenciaadatok miatt egy esetben sem sikerült meghatároznunk az integráció helyét. Ugyanakkor szinte minden transzformáns esetében ugyanazt a Southern hibridizációs mintázatot figyeltük meg, ami alapján úgy tűnik, hogy azonos helyekre történt az integráció, tehát az integráció szempontjából létezhetnek ún. „hotspotok” a genomban. Hasonló eredményre jutottak Michielse és mtsi. (2004) R. oryzae homológ pyr4 gén ATMT módszerrel történő integrációja során: nyolc vizsgált transzformáns közül két esetben génkicserélödést tapasztaltak, hat transzformáns esetében azonban heterológ helyre történt az integráció és minden esetben ugyanazon kromoszómális helyre. Egy vizsgálati módszer sem vezetett eredményre, amikor az ektopikus integráció helyét próbálták meghatározni.

\section{A kópiaszám, mitótikus stabilitás és transzkripció elemzése}

A crtW gén kópiaszámát, illetve az átoltások során megfigyelhető kópiaszámváltozást qPCR segítségével mértük (7. táblázat). Azt feltételeztük, hogy mind a protoplasztok, mind a spórák többmagvúsága miatt az abból fejlődő cönocitikus micélium heterokariotikus lesz, azaz egyes magok hordozzák majd a bakteriális gént (az integrációtól függően akár több kópiában is), mások viszont nem. Ennek megfelelően egy egykópiás kromoszómális gén kópiaszámával összehasonlítva annál lényegesen alacsonyabb kópiaszámot mérhetünk. Azt vártuk, hogy monosporangiális telepek izolálásával és folyamatos továbboltásával a szelekciós nyomás hatására a transzformáló DNS-t hordozó magok felszaporodnak, ezáltal a kontrollhoz viszonyítva fokozatosan (az átoltások számának növekedésével) emelkedni fog a crtW gén kópiaszáma. 


\begin{tabular}{|c|c|c|c|c|c|}
\hline \multirow[t]{2}{*}{$\begin{array}{c}\text { Transzformáns } \\
\text { törzs }\end{array}$} & \multicolumn{4}{|c|}{$\begin{array}{c}\text { A crtW gén relativ kópiaszámváltozása a } \\
\text { transzformáció utáni átoltások számának } \\
\text { növelésével (kópia/genom) }\end{array}$} & \multirow[t]{2}{*}{$\begin{array}{c}\text { Telep színe } \\
\text { (színváltozása) }\end{array}$} \\
\hline & 2. átoltás & 4. átoltás & 8. átoltás & 12. átoltás & \\
\hline MS12+pCA8lf/1 & 3 & 34 & 155 & 286 & SPN-PN \\
\hline MS12+pCA8lf/2 & 12 & na. & na. & 55 & SPN-PN \\
\hline MS12+pCA81f/3 & 0,03 & na. & na. & 0,07 & $S$ \\
\hline MS12+pCA9lf/1 & 0,5 & 11 & 21 & 145 & S-PN \\
\hline MS12+pCA91f/2 & 0,5 & 4 & na. & 62 & S-PN \\
\hline MS12+pCA8R/1 & na. & 0,01 & na. & na. & $\mathrm{S}$ \\
\hline $\mathrm{MS} 12+\mathrm{pCA} 8 \mathrm{R} / 2$ & na. & 0,9 & 1,09 & na. & $\mathrm{S}$ \\
\hline MS12+pCA8R/3 & na. & 0,05 & na. & na. & $\mathrm{S}$ \\
\hline $\mathrm{MS} 12+\mathrm{pCA} 8 \mathrm{R} / 4$ & na. & 46 & 10 & 13 & SPN \\
\hline MS12+pCA8R/5 & na. & 1,22 & na. & na. & $\mathrm{S}$ \\
\hline MS12+pPT51R1/1 & 5 & 12 & 14 & 23 & $\mathrm{PN}$ \\
\hline MS12+pPT51R1/2 & 3 & 9 & 13 & 74 & $\mathrm{PN}$ \\
\hline MS12+pPT51R1/3 & 5 & na. & na. & na. & $\mathrm{PN}$ \\
\hline MS12+pPT51R1/4 & 0,001 & na. & na. & 0,01 & $\mathrm{~S}$ \\
\hline MS12+pPT51R1/5 & 0,02 & na. & na. & na. & $S$ \\
\hline $\mathrm{MS} 12+\mathrm{pPK} 2 \mathrm{~W} / 1$ & na. & 0,002 & na. & na. & $\mathrm{S}$ \\
\hline $\mathrm{MS} 12+\mathrm{pPK} 2 \mathrm{~W} / 2$ & na. & 0,3 & na. & na. & $\mathrm{S}$ \\
\hline $\mathrm{MS} 12+\mathrm{pPK} 2 \mathrm{~W} / 3$ & na. & 0,003 & na. & na. & $\mathrm{S}$ \\
\hline $\mathrm{MS} 12+\mathrm{pPK} 2 \mathrm{~W} / 4$ & na. & 0,07 & na. & na. & $\mathrm{S}$ \\
\hline
\end{tabular}

7. táblázat. A transzformánsokban bejuttatott $c r t W$ gén relatív kópiaszámváltozása és a telepek színváltozása. PN - piros-narancs, SPN - átmenet sárga-piros-narancs között, S-sárga, na.-nincs adat, nem mértük.

Egyes transzformánsoknál valóban ez az eredmény volt megfigyelhető: az alacsony kezdeti kópiaszám az átoltások során emelkedett és elérte az 1 körüli relatív kópiaszámot (MS12+pCA8R/2 transzformáns, 7. táblázat). Egyes transzformánsokban a kópiaszám 13 átoltási ciklus után is alacsony maradt (MS12+pCA81f/3, MS12+pPT51R1/4 transzformánsok), úgy tünik, hogy ezekben a mutáns törzsekben fennmaradt a heterokariotikus állapot. Ugyanakkor más transzformánsok esetében a relatív kópiaszám már közvetlenül a transzformációt követően magasnak bizonyult, majd az átoltási ciklusok számának növelésével tovább nőtt (MS12+pCA81f/1-2, MS12+pCA9lf/1 és MS12+pPT51R1/2 transzformánsok) és egyes esetekben a 200 kópia/genom értéket is meghaladta (MS12+pCA81f/1 transzformáns). Ez az extrém magas kópiaszám a Southern hibridizációs és az inverz-PCR adatok figyelembevételével többféleképp magyarázható. Egyik lehetőség az, hogy a gomba genomjába integrálódott idegen DNS pontatlanul kivágódott, majd recirkularizációt követően képes volt nagyon nagy kópiaszámban felszaporodni (talán éppen a pontatlan kivágódásnak köszönhetően). Ilyen kivágódás adódhat a járomspórás gombáknál is már leírt, de ezidáig közvetlenül nem bizonyított genomvédő mechanizmusból (Takaya és mtsi. 1996, Ibrahim és Skory 2006). A lineáris fragmentumok összekapcsolódása, majd a már kompatibilis végek összekapcsolódása 
(esetlegesen a nem kompatibiliseké is ,non-homologous end joining” mechanizmussal, Skory 2005, Ibrahim és Skory 2006), tehát egy óriásmolekula (konkatamer) keletkezése is magyarázhatja a magas kópiaszámot. Ezen óriásmolekula ugyanakkor integrálódhatott a gomba genomjába, ez esetben a lineáris fragmentumok tandem ismétlődése figyelhető meg. Ilyen óriásmolekula kialakulásának lehetőségét már több publikációban is felvetették (Takaya és mtsi. 1996, Skory 2004, 2005).

Plazmidmenekítést végeztünk az integratív transzformánsokból izolált DNS-ből, amely során több esetben a bejuttatott transzformáló DNS-nél jelentősen kisebb méretű cirkuláris elemeket (2000-5500 bp közötti méretben) izoláltunk. Ezek a korábban leírtakhoz hasonlóan (ld. Eredmények és értékelésük, 6.2.3. fejezet) a transzformáló DNS átrendeződéséből származnak, mivel itt is azonosítani tudtunk plazmid szakaszokat (minden esetben lac $Z$ géncsonkokat). Ugyanakkor egyik esetben sem hordozták a crtW gént (vagy annak egy részét), ami megmagyarázza, hogy ezeket a cirkuláris elemeket miért nem tudtuk azonosítani a Southern hibridizációs mintázaton.

A mitótikus stabilitás vizsgálata során a lineáris fragmentummal transzformált törzsek többsége stabilnak bizonyult 15 egymást követő átoltási ciklus után is mind szelektív, mind nem szelektív tenyésztési körülmények között. A transzformánsokban a nem szelektív körülmények melletti tenyésztés során sem csökkent a $c r t W$ gén relatív kópiaszáma. Az ATMT módszerrel létrehozott összes törzs azonban instabilnak adódott minden tenyésztési körülmény között és 3 átoltás után a transzformánsok már nem voltak képesek növekedni. Mindez talán a bakteriális gén és a transzformációs módszer kombinációjából eredhet. Hasonló instabilitást kaptak Nyilasi és mtsi. $(2005,2008)$ mind Backusella lamprospora, mind M. circinelloides, valamint Monfort és mtsi. (2003) $R$. miehei heterológ génnel történő ATMT transzformációja során. Michielse és mtsi. (2004) $R$. oryzae esetében homológ génnel történő ATMT transzformációja során stabil transzformánsokat nyertek. Minden REMI transzformáns, amit a pPT51/NaeI-NdeI (MS12+pPT51R2) és pPT51/NaeI-ClaI (MS12+pPT51R3), valamint egy pCA8/SalI-SacI (MS12+pCA8R/1) fragmentum alkalmazásával nyert transzformáns szintén instabilnak bizonyult. Mindezen eredmények igazolják, hogy valóban müködik ennél a gombánál egy genomvédő mechanizmus, azonban a stabil transzformánsok azt jelzik, hogy talán kisebb aktivitással, mint más járomspórás gombáknál.

A transzkripció elemzése során kimutattuk, hogy a crtW gén kifejeződik a transzformánsokban. A relatív transzkripciós szintek a gén relatív kópiaszámát, illetve annak változását követték: ahol magas volt a relatív kópiaszám, ott a transzkripciós szint is magasnak bizonyult, ahol pedig alacsony, ott a transzkripciós szint is alacsony volt ( 8 . 
táblázat). Néhány transzformáns törzs esetében megvizsgáltuk a tenyésztési idő és a glükóz koncentráció hatását is a relatív transzkripciós szintekre (9. táblázat). A korábban tapasztaltakhoz hasonlóan 4 nap után a bakteriális gén nagyobb transzkripciós szintjét mértük, mint 1,5 nap után, valamint a magasabb glükóz koncentráció fokozott génexpressziót eredményezett. A transzformánsokba bejuttatott $\operatorname{crt} W$ gén gpdl promóter régió szabályozása alatt áll. Így nem meglepő a crtW gén expressziójának emelkedése, hiszen a gpdl promótere a glükóz koncentráció fokozásával indukálható (Wolff és Arnau 2002, Larsen és mtsi. 2004).

\begin{tabular}{|c|c|c|}
\hline $\begin{array}{c}\text { Transzformáns } \\
\text { törzs }\end{array}$ & $\begin{array}{c}\text { Relatív transzkripciós szint a } \\
\text { transzformáció utáni 3. átoltási } \\
\text { ciklus után }\end{array}$ & $\begin{array}{c}\text { Relatív transzkripciós szint a } \\
\text { transzformáció utáni 13. átoltási } \\
\text { ciklus után }\end{array}$ \\
\hline MS12+pCA81f/1 & 56 & 325 \\
\hline MS12+pCA81f/3 & 0,07 & na. \\
\hline MS12+pCA91f/1 & na. & 11 \\
\hline MS12+pCA91f/2 & 0,5 & $13(43)$ \\
\hline MS12+pCA8R/2 & 4 & na. \\
\hline MS12+pCA8R/4 & 13 & na. \\
\hline MS12+pCA8R/10 & 10 & na. \\
\hline MS12+pPT51R1/1 & 12 & na. \\
\hline MS12+pPT51R1/2 & 74 & 207 \\
\hline MS12+pPT51R1/4 & na. & 0,3 \\
\hline
\end{tabular}

8. táblázat. A relatív transzkripciós szintek korai és késői átoltások után. na.-nincs adat

\begin{tabular}{|c|c|c|c|}
\hline $\begin{array}{c}\text { Transzformáns } \\
\text { törzs }\end{array}$ & $\begin{array}{c}\text { Glükóz } \\
\text { koncentráció }\end{array}$ & $\begin{array}{c}\text { Relatív transzkripciós szint } \\
\mathbf{1 , 5} \text { nap tenyésztés után }\end{array}$ & $\begin{array}{c}\text { Relatív transzkripciós } \\
\text { szint 4 nap tenyésztés után }\end{array}$ \\
\hline \multirow{3}{*}{ MS12+pCA81f/1 } & $1 \%$ & 12 & na. \\
\cline { 2 - 4 } & $2,5 \%$ & 18 & na. \\
\cline { 2 - 4 } & $5 \%$ & 29 & na. \\
\hline \multirow{3}{*}{ MS12+pPT51R1/1 } & $1 \%$ & 10 & 207 \\
\cline { 2 - 4 } & $2,5 \%$ & 17 & 288 \\
\cline { 2 - 4 } & $5 \%$ & 93 & 143 \\
\hline
\end{tabular}

9. táblázat. A relatív transzkripciós szintek a glükóz koncentráció függvényében 1,5 és 4 nap tenyésztés után. na.-nincs adat

$\underline{\text { Karotintartalom elemzése }}$

Számos transzformáns nagy mennyiségben termelt oxigenált $\beta$-karotinszármazékokat, elsősorban kantaxantint és ehinenont, kis mértékben asztaxantint (10. táblázat), emellett a transzformánsok összkarotinoid-tartalma is növekedett az MS12 törzshöz képest. Közvetlenül a transzformáció után a transzformáns telepek színe általában sárga volt és ezekben a törzsekben az oxigenált karotinoidok koncentrációja alacsony volt. 


\begin{tabular}{|c|c|c|c|c|c|c|c|c|c|c|c|}
\hline Törzs & Átoltási ciklusszám & Likopin & $\beta$-karotin & $\gamma$-karotin & $\beta$-kriptoxantin & Zeaxantin & Kantaxantin & Ehinenon & Asztaxantin & Összkarotinoid & Szín \\
\hline MS12 & - & $12(3)$ & $249(61)$ & $22(5)$ & $26(6)$ & $8(2)$ & - & - & - & 412 & $\mathrm{~S}$ \\
\hline $\begin{array}{l}\text { MS12+pCA81f/1 } \\
\text { MS12+pCA81f/1 } \\
\text { MS12+pCA81f/1 } \\
\text { MS12+pCA81f/2 } \\
\text { MS12+pCA81f/2 } \\
\text { MS12+pCA81f/3 } \\
\text { MS12+pCA81f/3 }\end{array}$ & $\begin{array}{c}3 \\
6 \\
13 \\
6 \\
13 \\
3 \\
13\end{array}$ & $\begin{array}{l}9(2) \\
8(2) \\
12(2) \\
10(1) \\
15(2) \\
12(2) \\
10(2)\end{array}$ & \begin{tabular}{|c|}
$296(49)$ \\
$195(37)$ \\
$43(8)$ \\
$295(43)$ \\
$78(13)$ \\
$373(49)$ \\
$295(46)$
\end{tabular} & $\begin{array}{l}29(5) \\
23(4) \\
32(6) \\
38(6) \\
41(7) \\
32(4) \\
30(5)\end{array}$ & $\begin{array}{l}18(3) \\
14(3) \\
26(5) \\
14(2) \\
15(3) \\
21(3) \\
18(3)\end{array}$ & $\begin{array}{l}8(1) \\
8(2) \\
4(1) \\
6(1) \\
6(1) \\
9(1) \\
9(1)\end{array}$ & $\begin{array}{c}16(3) \\
25(5) \\
148(28) \\
65(9) \\
123(20) \\
16(2) \\
20(3)\end{array}$ & $\begin{array}{c}31(5) \\
59(11) \\
117(22) \\
60(9) \\
135(22) \\
27(4) \\
43(7)\end{array}$ & $\begin{array}{c}1(0,2) \\
-(-) \\
3(1) \\
-(-) \\
2(0,4) \\
1(0,1) \\
1(0,1)\end{array}$ & $\begin{array}{l}604 \\
535 \\
529 \\
692 \\
614 \\
757 \\
644\end{array}$ & $\begin{array}{c}\text { S } \\
\text { SPN } \\
\text { PN } \\
\text { SPN } \\
\text { PN } \\
\text { S } \\
\text { S }\end{array}$ \\
\hline $\begin{array}{l}\text { MS12+pCA91f/1 } \\
\text { MS12+pCA91f/1 } \\
\text { MS12+pCA91f/2 } \\
\text { MS12+pCA91f/2 }\end{array}$ & $\begin{array}{c}3 \\
13 \\
3 \\
13\end{array}$ & $\begin{array}{l}11(2) \\
12(2) \\
21(3) \\
15(2)\end{array}$ & $\begin{array}{l}377(55) \\
190(30) \\
397(51) \\
281(40)\end{array}$ & $\begin{array}{l}30(4) \\
32(5) \\
31(4) \\
35(5)\end{array}$ & $\begin{array}{l}24(4) \\
16(3) \\
32(4) \\
20(3)\end{array}$ & $\begin{array}{c}7(1) \\
8(1) \\
10(1) \\
5(1)\end{array}$ & $\begin{array}{c}6(1) \\
71(11) \\
9(1) \\
50(7)\end{array}$ & $\begin{array}{l}9(1) \\
57(9) \\
11(1) \\
45(7)\end{array}$ & $\begin{array}{c}-(-) \\
2(0,2) \\
-(-) \\
2(0,3)\end{array}$ & $\begin{array}{l}688 \\
636 \\
785 \\
697\end{array}$ & $\begin{array}{l}\text { S } \\
\text { SPN } \\
\text { S } \\
\text { SPN }\end{array}$ \\
\hline $\begin{array}{l}\text { MS12+pCA8R/2 } \\
\text { MS12+pCA8R/2 } \\
\text { MS12+pCA8R/4 } \\
\text { MS12+pCA8R/4 } \\
\text { MS12+pCA8R/5 } \\
\text { MS12+pCA8R/5 }\end{array}$ & $\begin{array}{c}3 \\
13 \\
3 \\
13 \\
3 \\
13\end{array}$ & $\begin{array}{l}10(2) \\
14(3) \\
12(3) \\
12(3) \\
8(2) \\
13(3)\end{array}$ & $\begin{array}{l}358(67) \\
360(67) \\
209(52) \\
196(48) \\
325(66) \\
337(66)\end{array}$ & $\begin{array}{l}30(6) \\
30(5) \\
25(6) \\
31(8) \\
28(6) \\
28(6)\end{array}$ & $\begin{array}{l}29(5) \\
25(5) \\
18(4) \\
16(4) \\
29(6) \\
25(5)\end{array}$ & $\begin{array}{l}11(2) \\
7(1) \\
6(2) \\
6(2) \\
14(3) \\
6(1)\end{array}$ & $\begin{array}{l}5(1) \\
4(1) \\
31(8) \\
29(7) \\
6(1) \\
4(1)\end{array}$ & $\begin{array}{c}3(0,5) \\
8(2) \\
37(9) \\
44(11) \\
3(1) \\
8(2)\end{array}$ & $\begin{array}{c}0,3(0,1) \\
0,7(0,1) \\
-(-) \\
-(-) \\
-(-) \\
0,4(0,1)\end{array}$ & $\begin{array}{l}533 \\
540 \\
405 \\
407 \\
495 \\
508\end{array}$ & $\begin{array}{c}\text { S } \\
\text { S } \\
\text { SPN } \\
\text { SPN } \\
\text { S } \\
\text { S }\end{array}$ \\
\hline $\begin{array}{l}\text { MS12+pPT51R } 1 / 2 \\
\text { MS12+pPT51R } 1 / 2 \\
\text { MS12+pPT51R1/4 } \\
\text { MS12+pPT51R } 1 / 4\end{array}$ & $\begin{array}{c}3 \\
13 \\
3 \\
13\end{array}$ & $\begin{array}{l}23(5) \\
11(2) \\
12(2) \\
-(-)\end{array}$ & $\begin{array}{c}58(13) \\
40(8) \\
359(61) \\
390(54)\end{array}$ & $\begin{array}{l}51(11) \\
28(6) \\
25(4) \\
21(3)\end{array}$ & $\begin{array}{l}17(4) \\
21(4) \\
20(3) \\
38(5)\end{array}$ & $\begin{array}{l}4(1) \\
8(2) \\
9(2) \\
10(1)\end{array}$ & $\begin{array}{c}109(24) \\
119(24) \\
6(1) \\
10(1)\end{array}$ & $\begin{array}{c}120(26) \\
97(19) \\
7(1) \\
6(1)\end{array}$ & $\begin{array}{c}0,4(0,1) \\
0,1(0,02) \\
0,5(0,1) \\
1(0,2)\end{array}$ & $\begin{array}{l}460 \\
501 \\
583 \\
729\end{array}$ & $\begin{array}{c}\text { PN } \\
\text { PN } \\
\text { S } \\
\text { S }\end{array}$ \\
\hline $\mathrm{MS} 12+\mathrm{pPK} 2 \mathrm{~W} / 1$ & 2 , nem stabil & $-(-)$ & $427(65)$ & $20(3)$ & $39(6)$ & $11(2)$ & $11(2)$ & $4(1)$ & $-(-)$ & 652 & S \\
\hline
\end{tabular}

10. táblázat. Különböző integratív transzformáns törzsek összkarotinoid-termelése szárazsúlyra vonatkoztatva ( $\mu \mathrm{g} / \mathrm{g})$, valamint annak összetétele és változása az átoltások során. A felsorolt törzsek egy-egy típust képviselnek az egyes módszerekkel elöállított transzformáns törzsek közül aszerint, hogy hogyan változott a karotinoid termelésük. Zárójelben jelöltük az adott karotinoid százalékos arányát az összkarotinoid-tartalomra vonatkoztatva.

$\mathrm{S}$ - sárga, $\mathrm{PN}$ - piros-narancs, SPN - sárga-piros-narancs. 
Kivételt a pPT51R1/1 és pPT51R1/2 transzformánsok képeztek, melyek közvetlenül a transzformáció után intenzív piros-narancs színűek voltak, jelezve az oxigenált karotinoidok akkumulációját, amit a HPLC mérések is alátámasztottak (10. táblázat). Ezt a fenotípust az átoltások során megtartották (10. táblázat), ezek a törzsek nagy mennyiségben termeltek kantaxantint és ehinenont.Több mint 10 átoltás után a xantofillok aránya jelentősen megnőtt a karotinokhoz képest a kezdetben sárga színü telepek többségében is (10. táblázat). Kiemelkedik ezen törzsek közül az MS12+pCA81f/1 és az MS12+pCA81f/2, melyek a legnagyobb mennyiségben szintetizáltak kantaxantint és ehinenont. Az MS12+pPK2W, MS12+pCA8R, valamint az MS12+pCA81f/3 transzformánsok az átoltások számától függetlenül sárgák maradtak, vagyis ezek a törzsek legnagyobb mennyiségben $\beta$-karotint termeltek. Néhány piros-narancs színủ transzformáns képe a 38. ábrán látható, a 39. ábrán pedig az egyik transzformáns törzs karotinoid összetételének TLC analízisét mutatjuk be, összehasonlítva az MS12+pPT51 törzzsel (ami szintén a $c r t W$ gént hordozta, de autonóm replikálódó plazmidon).

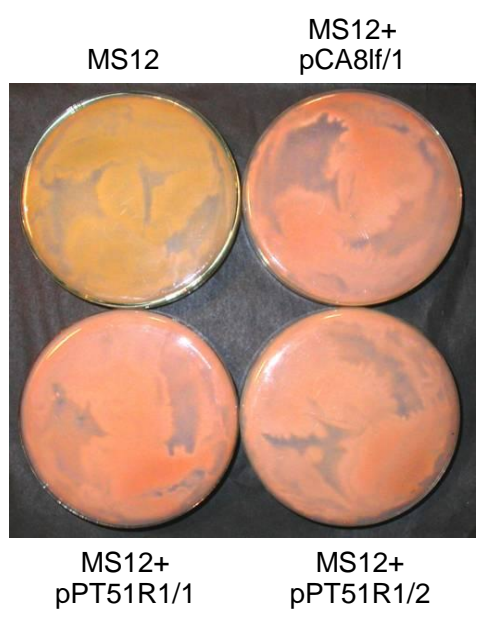

38. ábra. Néhány xantofilltermelő transzformáns törzs, összehasonlítva az MS12-vel.

A szárazsúlyra vonatkoztatott karotinoid-tartalmat tekintve a sárga telepekben nagyobb összkarotinoid-tartalmat mértünk, mint a piros-narancs színűekben. Ez a különbség egy transzformáns telep vizsgálata során is megfigyelhető volt, amikor az átoltások során a színe sárgáról piros-narancsra változott (10. táblázat).

Megállapítható, hogy a crtW gén relatív kópiaszáma és az oxigenált karotinoidok mennyisége egyenes arányban van egymással: magasabb kópiaszám esetén magasabb volt a kantaxantin és az ehinenon koncentrációja. Az MS12+pPT51R1/1 és az MS12+pPT51R1/2 törzsekben az oxigenált $\beta$-karotinszármazékok kezdeti, illetve folyamatosan magas koncentrációja leginkább azt a hipotézist támasztja alá, miszerint a lineáris fragmentumok összekapcsolódásával létrejött óriásmolekulák integrálódtak a 
gomba genomjába. Az MS12+pCA81f/1 és MS12+pCA81f/2 törzsekben a folyamatosan emelkedő kantaxantin és ehinenon koncentrációt inkább az integráció utáni pontatlan kivágódás, recirkularizáció, majd a cirkuláris genetikai elemek felszaporodása magyarázhatja.
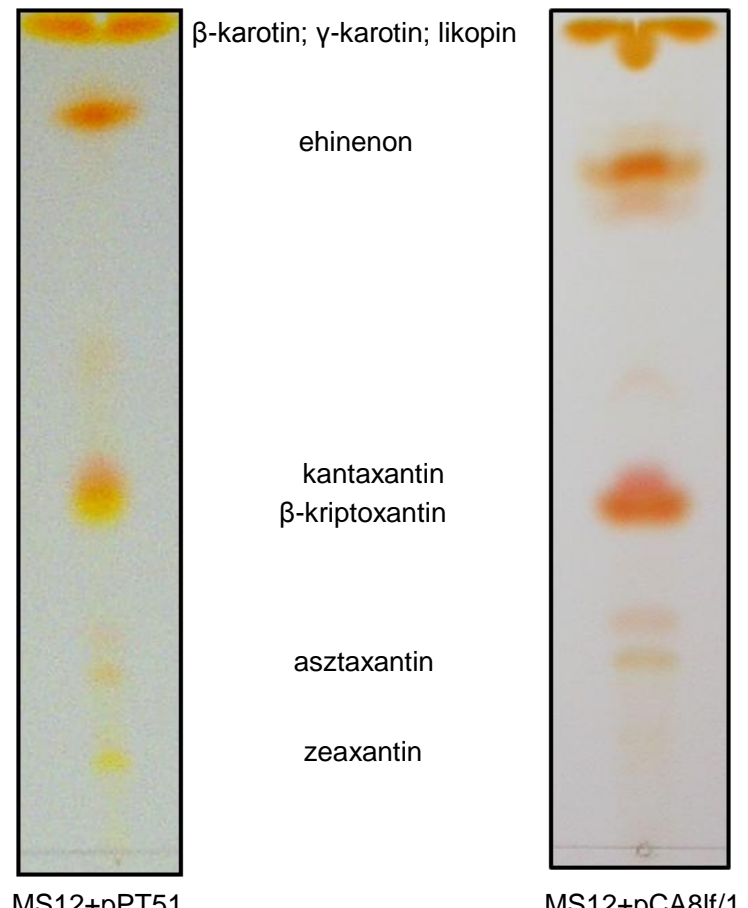

39. ábra. Az MS12+pPT51 és az MS12+pCA81f/1 transzformáns törzsek karotinoid termelésének összehasonlító TLC analízise.

Meghatároztuk a transzformánsok karotinoid termelését nem szelektív tenyésztési körülmények között is (MEA, valamint uracillal és leucinnal kiegészített YNB táptalajon), kontrollként a szelektív körülmények között mért karotinoid-termelést vettük. Egyik esetben sem volt jelentős mértékü eltérés a termelt karotinoidok mennyiségében és csak nagyon kis mértékben tért el a karotinoid-összetétel.

Két transzformáns törzs esetében részletesen megvizsgáltuk a különböző tenyésztési körülmények (fény, hömérséklet, különböző szénforrások) hatását a törzsek karotinoid termelésére. A korábbi mérések alapján a vizsgálatokhoz az MS12+pCA81f/1 és az MS12+pCA91f/1 törzseket választottuk.

Állandó megvilágítást alkalmazva a Daylight fényforrás közel 1,5-szeres karotinoid-termelés növekedést eredményezett a Warm White fényforráshoz képest a két transzformáns és az MS12 esetében is, a karotinoid-összetétel szempontjából azonban csak kismértékü eltérést tapasztaltunk. M. circinelloides esetében a kék fény karotintermelés szabályozásában betöltött szerepe régóta ismert (Iturriaga és mtsi. 2000). Mint az irodalmi áttekintésben is említettem, a kék fény indukálja a karotinszintézisben szerepet játszó 
gének átíródását (Velayos és mtsi. 2000a, 2000b, 2003). A két tesztelt fényforrás közt a fény összetételében van eltérés: az alacsony színhőmérsékletü fény (Warm White, 3000K) a sárga-vörös, míg a magas színhőmérsékletü (Daylight, 6000K) a kék tartományban intenzívebb, ami megmagyarázza, hogy a Daylight fényforrás miért eredményezett magasabb karotinoid-termelést. A fényintenzitás a kísérletek során állandó volt, amit azért fontos megemlíteni, mert Orset és Young (1999) Dunaliella salina, Boussiba (1992) pedig Hematococcus pluvialis esetében mutatta ki, hogy a fényintenzitás fokozása növeli a karotinoid-termelést, amit Shais és mtsi. (1993) az aktív oxigén molekulák képződésén keresztül a karotinoid-bioszintézis stimulációjával magyaráznak. Steinbrenner és Linder (2001) H. pluvialis-ban a karotin-bioszintézis gének (fitoén szintáz, hidroxilázok) transzkripciós szintjének növekedését mérték a fényintenzitás növelésével.

Vizsgáltuk a transzformánsok karotinoid termelését különböző tenyésztési hőmérsékleteken is $\left(20,25,30,35\right.$ és $37^{\circ} \mathrm{C}$-on), és a legmagasabb karotinoid-termelést 35 ${ }^{\circ} \mathrm{C}$-on mértük. $37{ }^{\circ} \mathrm{C}$-on a gombák már gyengén nőttek, de a transzformánsok az MS12-nél nagyobb túlélőképességet mutattak. Megfigyelhető volt, hogy az alacsonyabb hőmérséklet kedvezett az oxigenált karotinoid-származékok szintézisének $\left(20{ }^{\circ} \mathrm{C}\right.$-on volt a legmagasabb), míg a magasabb hömérsékleten a $\beta$-karotin mennyisége volt nagyobb (40. ábra). Korábbi vizsgálatokban Mosqueda-Cano és Gutierrez-Corona (1995) Mucor rouxii esetében a hőmérséklet emelésével szintén fokozni tudták a karotinoid-termelést. Simpson és mtsi. (1964) Rhodotorula glutinis-ben leírták, hogy a karotinoid-bioszintézisben a dehidrogénezéses és dekarboxilációs lépések hőmérsékletfüggőek. Kutatócsoportunk is igazolta, hogy a $X$. dendrorhous alacsonyabb hőmérsékleten több karotinoidot termel, mint magasabb hőmérsékleten.

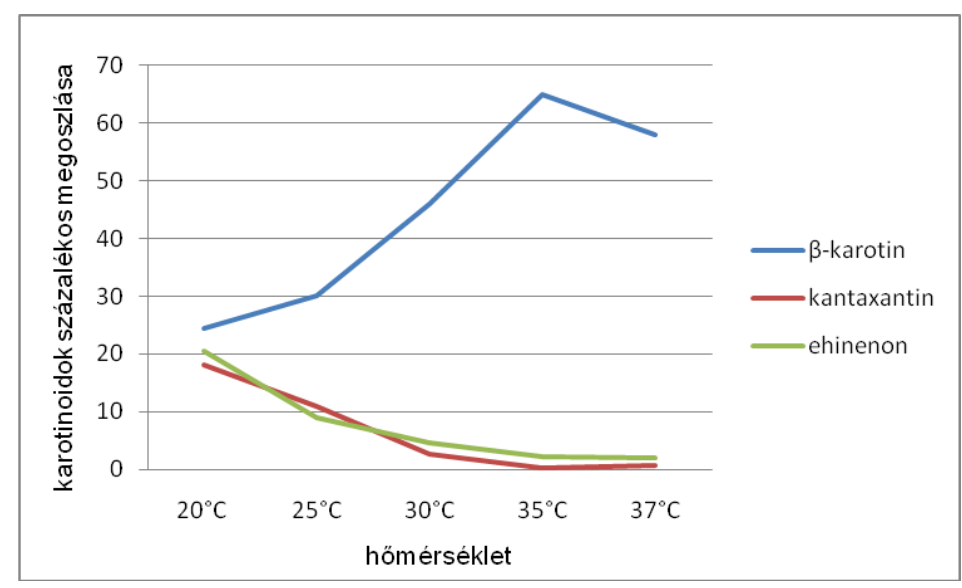

40. ábra. A hőmérséklet hatása a különböző karotinoidok termelődésére. Az értékek az adott karotinoid százalékos arányát jelzik. Az ábrán a vizsgálatok szempontjából jelentős három karotinoidot tüntettük csak fel. 
Több mint 20 átoltási ciklust követően a transzformánsok karotinoid termelését különböző szénforrásokkal, valamint adalékanyagokkal kiegészített minimál táptalajon, továbbá tápoldatban, állandó rázatás mellett is vizsgáltuk. Az összkarotinoid-tartalmakat, a legnagyobb mennyiségben termelt karotinoidokkal együtt a 11. táblázat szemlélteti.

\begin{tabular}{|c|c|c|c|c|c|}
\hline Törzs & Szénforrás/adalékanyag & $\beta$-karotin & Kantaxantin & Ehinenon & Összkarotinoid \\
\hline $\begin{array}{l}\text { MS12+pCA81f/1 } \\
\text { MS12+pCA91f/1 }\end{array}$ & 1\% D-glükóz & $\begin{array}{c}34(7) \\
215(36)\end{array}$ & $\begin{array}{l}169(33) \\
80(13)\end{array}$ & $\begin{array}{c}103(20) \\
65(11)\end{array}$ & $\begin{array}{l}511 \\
596\end{array}$ \\
\hline $\begin{array}{l}\text { MS12+pCA81f/1 } \\
\text { MS12+pCA91f/1 }\end{array}$ & D-mannóz & $\begin{array}{c}74(10) \\
271(34)\end{array}$ & $\begin{array}{l}198(26) \\
139(17)\end{array}$ & $\begin{array}{c}165(22) \\
84(10)\end{array}$ & $\begin{array}{l}749 \\
799\end{array}$ \\
\hline $\begin{array}{l}\text { MS12+pCA81f/1 } \\
\text { MS12+pCA91f/1 }\end{array}$ & trehalóz & $\begin{array}{c}61(9) \\
268(34)\end{array}$ & $\begin{array}{l}209(31) \\
122(16)\end{array}$ & $\begin{array}{l}149(22) \\
88(11)\end{array}$ & $\begin{array}{l}684 \\
781\end{array}$ \\
\hline $\begin{array}{l}\text { MS12+pCA81f/1 } \\
\text { MS12+pCA91f/1 }\end{array}$ & D-fruktóz & $\begin{array}{c}88(15) \\
199(27) \\
\end{array}$ & $\begin{array}{l}109(18) \\
139(19) \\
\end{array}$ & $\begin{array}{c}136(23) \\
86(12) \\
\end{array}$ & $\begin{array}{l}595 \\
746 \\
\end{array}$ \\
\hline $\begin{array}{l}\text { MS12+pCA81f/1 } \\
\text { MS12+pCA91f/1 }\end{array}$ & D-galaktóz & $\begin{array}{c}68(12) \\
166(26)\end{array}$ & $\begin{array}{l}153(26) \\
108(17)\end{array}$ & $\begin{array}{l}124(21) \\
108(17)\end{array}$ & $\begin{array}{l}584 \\
631\end{array}$ \\
\hline $\begin{array}{l}\text { MS12+pCA81f/1 } \\
\text { MS12+pCA91f/1 }\end{array}$ & L-aszparaginsav & $\begin{array}{c}21(4) \\
204(38) \\
\end{array}$ & $\begin{array}{c}222(45) \\
50(8)\end{array}$ & $\begin{array}{l}78(16) \\
87(14) \\
\end{array}$ & $\begin{array}{l}494 \\
609 \\
\end{array}$ \\
\hline $\begin{array}{l}\text { MS12+pCA81f/1 } \\
\text { MS12+pCA91f/1 }\end{array}$ & dihidroxi-aceton & $\begin{array}{c}15(4) \\
77(13)\end{array}$ & $\begin{array}{l}232(55) \\
144(24)\end{array}$ & $\begin{array}{c}35(8) \\
142(24)\end{array}$ & $\begin{array}{l}426 \\
590 \\
\end{array}$ \\
\hline $\begin{array}{l}\text { MS12+pCA81f/1 } \\
\text { MS12+pCA91f/1 }\end{array}$ & glicerin & $\begin{array}{l}53(13) \\
50(11)\end{array}$ & $\begin{array}{c}79(19) \\
163(37)\end{array}$ & $\begin{array}{l}35(8) \\
34(8)\end{array}$ & $\begin{array}{l}411 \\
437\end{array}$ \\
\hline $\begin{array}{l}\text { MS12+pCA81f/1 } \\
\text { MS12+pCA9lf/1 }\end{array}$ & glicerin-L-monoacetát & $\begin{array}{c}40(9) \\
126(38) \\
\end{array}$ & $\begin{array}{l}169(39) \\
71(18)\end{array}$ & $\begin{array}{l}69(16) \\
42(11) \\
\end{array}$ & $\begin{array}{l}430 \\
402 \\
\end{array}$ \\
\hline $\begin{array}{l}\text { MS12+pCA81f/1 } \\
\text { MS12+pCA91f/1 }\end{array}$ & cellobióz & $\begin{array}{c}19(6) \\
56(28)\end{array}$ & $\begin{array}{c}114(36) \\
43(21)\end{array}$ & $\begin{array}{c}58(19) \\
18(9)\end{array}$ & $\begin{array}{l}314 \\
203\end{array}$ \\
\hline $\begin{array}{l}\text { MS12+pCA81f/1 } \\
\text { MS12+pCA91f/1 }\end{array}$ & maltóz & $\begin{array}{c}27(6) \\
95(25) \\
\end{array}$ & $\begin{array}{c}139(33) \\
49(13) \\
\end{array}$ & $\begin{array}{l}82(19) \\
27(7) \\
\end{array}$ & $\begin{array}{l}428 \\
385 \\
\end{array}$ \\
\hline $\begin{array}{l}\text { MS12+pCA81f/1 } \\
\text { MS12+pCA91f/1 }\end{array}$ & etanol & $\begin{array}{c}40(12) \\
14(7) \\
\end{array}$ & $\begin{array}{c}117(34) \\
85(41) \\
\end{array}$ & $\begin{array}{c}28(8) \\
35(17) \\
\end{array}$ & $\begin{array}{l}341 \\
208 \\
\end{array}$ \\
\hline $\begin{array}{l}\text { MS12+pCA81f/1 } \\
\text { MS12+pCA91f/1 }\end{array}$ & 2,5\% D-glükóz & $\begin{array}{c}61(10) \\
161(31) \\
\end{array}$ & $\begin{array}{c}143(25) \\
41(8)\end{array}$ & $\begin{array}{c}115(20) \\
99(19) \\
\end{array}$ & $\begin{array}{l}580 \\
513 \\
\end{array}$ \\
\hline $\begin{array}{l}\text { MS12+pCA81f/1 } \\
\text { MS12+pCA91f/1 }\end{array}$ & $5 \%$ D-glükóz & $\begin{array}{c}37(7) \\
50(15) \\
\end{array}$ & $\begin{array}{c}144(26) \\
56(17)\end{array}$ & $\begin{array}{c}120(22) \\
85(26)\end{array}$ & $\begin{array}{l}546 \\
329 \\
\end{array}$ \\
\hline $\begin{array}{l}\text { MS12+pCA81f/1 } \\
\text { MS12+pCA91f/1 }\end{array}$ & D-glükóz+pálmaolaj & $\begin{array}{c}17(8) \\
48(23)\end{array}$ & $\begin{array}{l}54(26) \\
23(11)\end{array}$ & $\begin{array}{c}41(20) \\
16(8)\end{array}$ & $\begin{array}{l}209 \\
205\end{array}$ \\
\hline $\begin{array}{l}\text { MS12+pCA81f/1 } \\
\text { MS12+pCA91f/1 }\end{array}$ & D-glükóz, pH3,0 & $\begin{array}{l}51(19) \\
71(20) \\
\end{array}$ & $\begin{array}{l}42(15) \\
45(13)\end{array}$ & $\begin{array}{l}63(23) \\
80(23) \\
\end{array}$ & $\begin{array}{l}276 \\
348 \\
\end{array}$ \\
\hline $\begin{array}{l}\text { MS12+pCA81f/1 } \\
\text { MS12+pCA91f/1 }\end{array}$ & D-glükóz $+\mathrm{H}_{2} \mathrm{O}_{2}$ & $\begin{array}{c}11(6) \\
52(16) \\
\end{array}$ & $\begin{array}{l}77(40) \\
78(24) \\
\end{array}$ & $\begin{array}{l}27(14) \\
43(13) \\
\end{array}$ & $\begin{array}{l}192 \\
325 \\
\end{array}$ \\
\hline $\begin{array}{l}\text { MS12+pCA81f/1 } \\
\text { MS12+pCA91f/1 }\end{array}$ & D-glükóz+FeSO & $\begin{array}{c}24(8) \\
104(27)\end{array}$ & $\begin{array}{c}110(35) \\
67(17)\end{array}$ & $\begin{array}{l}47(15) \\
27(7)\end{array}$ & $\begin{array}{l}312 \\
385\end{array}$ \\
\hline $\begin{array}{l}\text { MS12+pCA81f/1 } \\
\text { MS12+pCA9lf/1 }\end{array}$ & D-glükóz $+\mathrm{CuSO}_{4}$ & $\begin{array}{c}6(6) \\
62(25) \\
\end{array}$ & $\begin{array}{l}42(43) \\
44(18) \\
\end{array}$ & $\begin{array}{l}10(10) \\
26(10) \\
\end{array}$ & $\begin{array}{c}98 \\
246 \\
\end{array}$ \\
\hline $\begin{array}{l}\text { MS12+pCA81f/1 } \\
\text { MS12+pCA91f/1 }\end{array}$ & $\mathrm{D}$-glükóz $+\mathrm{CoCl}_{2}$ & $\begin{array}{l}62(17) \\
30(13)\end{array}$ & $\begin{array}{c}26(7) \\
-(-) \\
\end{array}$ & $\begin{array}{l}70(19) \\
39(17) \\
\end{array}$ & $\begin{array}{l}362 \\
229 \\
\end{array}$ \\
\hline $\begin{array}{l}\text { MS12+pCA81f/1 } \\
\text { MS12+pCA91f/1 }\end{array}$ & rázatott tenyészet, D-glükózzal & $\begin{array}{l}4(4) \\
9(6)\end{array}$ & $\begin{array}{l}35(33) \\
40(30)\end{array}$ & $\begin{array}{c}9(9) \\
20(15)\end{array}$ & $\begin{array}{l}105 \\
135\end{array}$ \\
\hline
\end{tabular}

11. táblázat. Két transzformáns törzs karotinoid termelése szárazsúlyra vonatkoztatva $(\mu \mathrm{g} / \mathrm{g})$ különböző szénforrást vagy adalékanyagot tartalmazó táptalajokon. A táblázatban a legnagyobb mennyiségben előforduló karotinoidok, valamint zárójelben azok százalékos aránya látható. 
Az MS12+pCA81f/1 és az MS12+pCA91f/1 törzs a termelt karotinoidok mennyiségében nem, csak összetételében tért el jelentősebb mértékben egymástól. A 41. ábrán az MS12+pCA81f/1 törzs látható különböző szénforrás tartalmú táptalajon nevelve, illetve folyadék tenyészetben az MS12 törzzsel összehasonlítva. A D-galaktóz, D-fruktóz, trehalóz és a D-mannóz jelentős növekedést, míg az L-aszparaginsav, dihidroxi-aceton, glicerin, glicerin-L-monoacetát, maltóz, cellobióz, etanol, illetve a különböző adalékanyagok csökkenést okoztak az összkarotinoid termelésben, összehasonlítva a Dglükózon nevelt tenyészettel. Kobayashi és mtsi. (1992) H. pluvialis esetében leírták, hogy a vas-sók hatására fokozódott az asztaxantin produkció. Tjahjono és mtsi. (1994) ezt a Fenton reakció során képződő hidroxil gyökökkel, illetve azok karotin-bioszintézist stimuláló hatásával magyarázták. A fémionokról kimutatták, hogy általában fokozzák a karotinoid-termelést élesztőkben, valamint fonalas gombákban is (Atamanyuk és Razumorskii 1974, Mahattanatavee és Kulprecha 1991, Bhosale 2004). Ugyanakkor An és mtsi. (1996) X. dendrorhous-ban mangán sók hatására csökkenést figyeltek meg. Mindezek szintén az oxid gyökök képződésével, valamint a fémionok enzimek kofaktoraiként betöltött szerepével magyarázhatók.
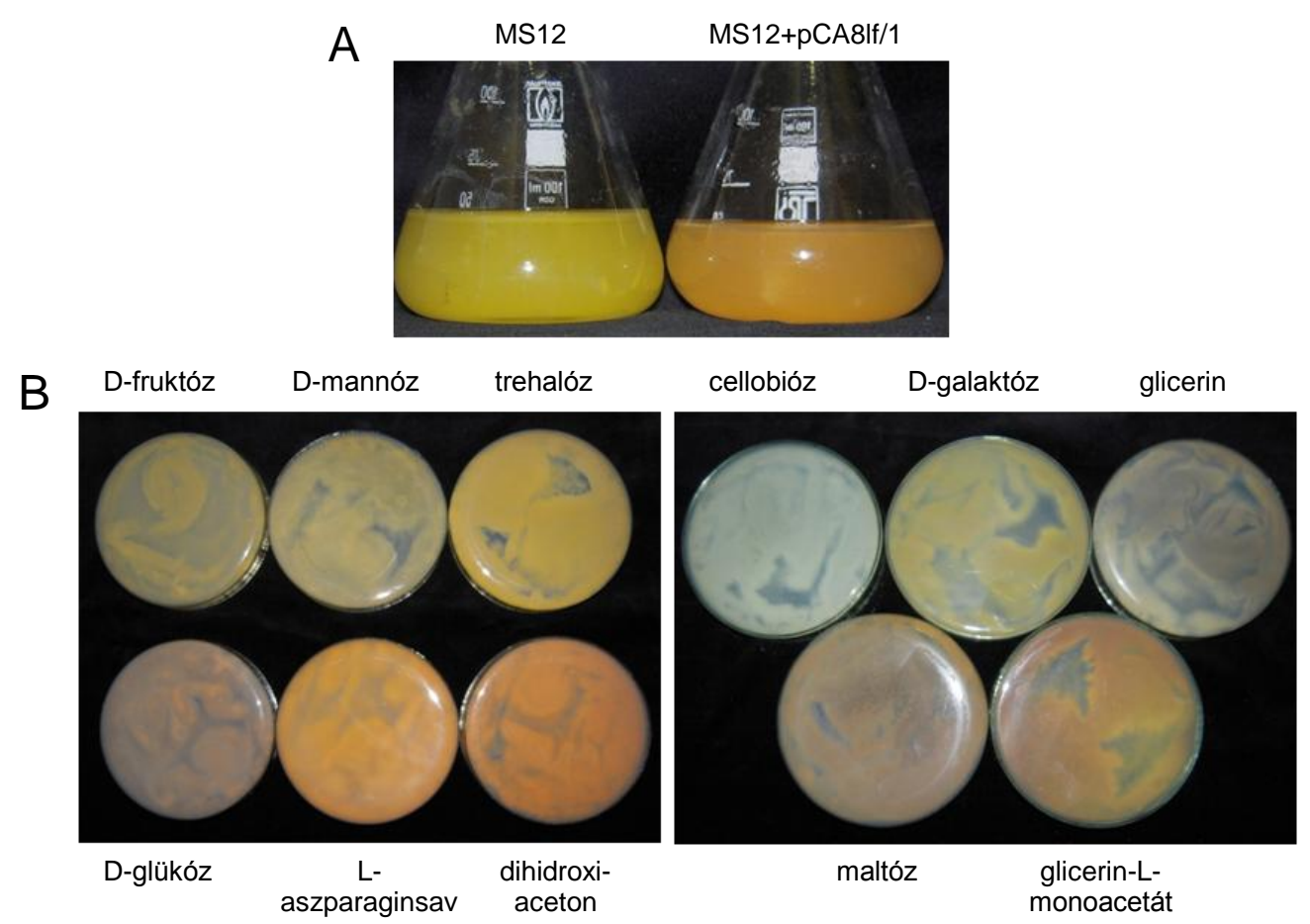

41. ábra. Az MS12+pCA81f/1 integratív transzformáns törzs fenotípusa különböző szénforrás tartalmú táptalajon és folyadéktenyészetben, a teljesség igénye nélkül.

A: rázatott tenyészetben, az MS12 törzzsel összehasonlítva.

B: különböző szénforrás tartalmú táptalajokon. 
Kísérleteinkben több szénforrás és adalékanyag jelentősen megnövelte a xantofillok mennyiségét: az MS12 törzsben a glicerin, etanol és dihidroxi-aceton fokozta a hidroxilált származékok mennyiségét (zeaxantin kettö-négyszeresére, $\beta$-kriptoxantin kétszeresére emelkedett). A transzformánsok esetében a dihidroxi-acetonnal, L-aszparaginsavval, valamint a hidrogén-peroxiddal és réz-szulfáttal kiegészített táptalajon történő tenyésztés a ketoszármazékok mennyiségének és/vagy arányának emelkedését eredményezte. Így pl. dihidroxi-aceton tartalmú táptalajon szinte teljesen megtörtént a $\beta$-karotin-kantaxantin átalakulás (42. ábra).

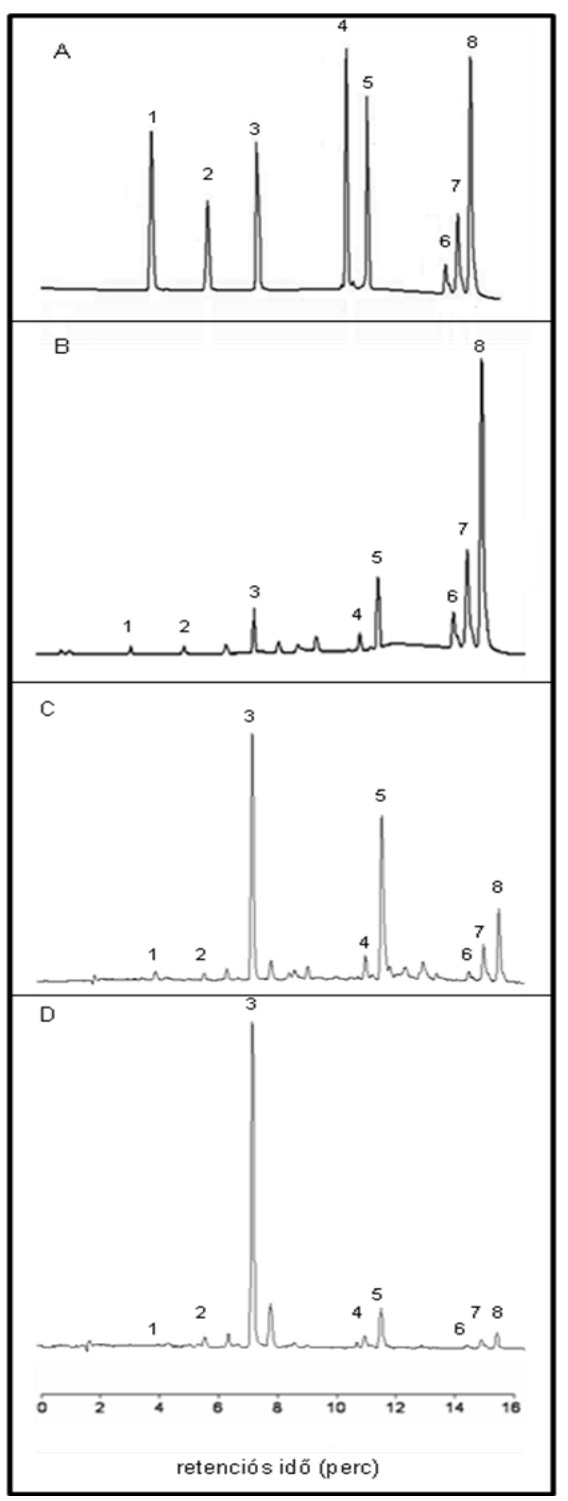

42. ábra. Néhány karotinoid minta HPLC kromatogramja. A számok által jelölt karotinoidok: 1: asztaxantin, 2: zeaxantin, 3: kantaxantin, 4: $\beta$-kriptoxantin, 5: ehinenon, 6: likopin, 7: $\gamma$-karotin, 8: $\beta$ karotin.

A: Standardok

B: MS12+pPT51 D-glükózon tenyésztett transzformáns törzs

C: MS12+pCA81f/1 D-glükózon tenyésztett transzformáns törzs

D: MS12+pCA81f/1 dihidroxi-acetonon tenyésztett transzformáns törzs 
Ezekben a transzformánsokban a kantaxantin mennyisége összemérhető más, az iparban potenciálisan alkalmazott mikrobák kantaxantintermelő képességével (Bhosale és Bernstein 2005). Vázquez és mtsi. (1997) Phaffia rhodozyma esetében kimutatták, hogy a xilóz megnövelte az asztaxantin mennyiségét. Liu és Wu (2006) hidrogén-peroxid, Gu és mtsi. (1997) etanol, Csernetics és mtsi. (2007) pedig olajok (elsősorban pálmaolaj) segítségével értek el hasonló hatást, amikor azt Phaffia tenyészethez adták. Az etanol a karotinoid-termelés mellett a biomassza növekedését is eredményezte. Az MS12+pCA91f/1 törzs esetében a különböző szénforrást, illetve adalékanyagot tartalmazó táptalajokon nagyobb arányú $\beta$-karotin-xantofill átalakulást mértünk a glükóz tartalmú táptalajon nevelt tenyészethez képest, mint az MS12+pCA81f/1 transzformáns esetében, mivel a törzs eleve kevesebb xantofillt tartalmazott.

Rázatott tenyészetben alacsonyabb összkarotinoid-tartalmat mértünk, mint szilárd táptalajon (általánosságban öt-hatszor kevesebbet), így az MS12+pCA81f/1 törzs esetében a szárazanyagtartalomra vonatkoztatott karotinoid-mennyiség glükóz tartalmú tápoldatban $105 \mu \mathrm{g} / \mathrm{g}$, míg a legmagasabb $(153 \mu \mathrm{g} / \mathrm{g})$ trehalóz tartalmú tápoldatban volt. A fruktóz, trehalóz, mannóz, valamint a pálmaolajjal kiegészített glükóz tartalmú tápoldat közel másfélszeres növekedést eredményezett a kantaxantin/ $\beta$-karotin arányban a szilárd táptalajon nevelt micéliumokból tisztított karotinoid mintákkal összehasonlítva, illetve átlagosan kétszeres növekedést tapasztaltunk a $\beta$-kriptoxantin/ $\beta$-karotin arány tekintetében.

$\mathrm{Az}$ asztaxantin koncentrációja minden transzformáns esetében alacsony maradt, jelezve, hogy a $M$. circinelloides $\beta$-karotin hidroxiláza nem vagy csak kis mértékben képes szubsztrátként hasznosítani a kantaxantint. Ezért a Paracoccus sp. N81106 törzs crtZ génjét a 6.1. fejezetben leírt autonóm replikálódó plazmidon (pPT50) az MS12+pCA81f/1 és az MS12+pPT51R1/1 transzformáns törzsekbe juttattuk PEG-mediált protoplaszt transzformációval. Mindkét transzformáció során 20-25 transzformáns telepet izoláltunk.

A kezdeti átoltások után az asztaxantin koncentrációja alacsony maradt, valamint a kantaxantin és az ehinenon koncentrációja is lecsökkent. Többszöri átoltás után azonban növekedést mértünk a xantofillok koncentrációjában. Megvizsgáltuk a transzformánsok asztaxantin termelését az előzőekben leírt tenyésztési körülmények között (különböző hőmérsékleten, fényforráson, szénforrást tartalmazó táptalajon, adalékanyagokkal kiegészített táptalajon). Az összkarotinoid tekintetében az integratív transzformáns törzsekkel azonos kinetikát mértünk. Glükóz tartalmú táptalajon az MS12+pCA81f/1+pPT50/1 törzsben $737 \mu \mathrm{g} / \mathrm{g}$, az MS12+pPT51R/1+pPT50/1 törzsben pedig $611 \mu \mathrm{g} / \mathrm{g}$ szárazanyagtartalomra vonatkoztatott összkarotinoid-tartalmat mértünk. Az asztaxantin mennyisége 8 és $13 \mu \mathrm{g} / \mathrm{g}$ volt (ami 1-2\%-a az összkarotinoidnak). Az 
MS12+pPT51R/1+pPT50/1 törzsben mannózon, L-aszparaginsavon, valamint $30{ }^{\circ} \mathrm{C}$-on Dglükózon nevelve az asztaxantin mennyisége az összkarotinoid 4\%-ára emelkedett (17, 28 és $30 \mu \mathrm{g} / \mathrm{g}$,). A transzformánsokban mind a zeaxantin, mind a $\beta$-kriptoxantin mennyisége átlagban a kétszeresére emelkedett az MS12+pPT51R1/1 és MS12+pCA81f/1 törzsekkel összehasonlítva. A crtZ gén integrációja a két transzformáns törzs genomjába jelenleg is folyamatban van, remélhetöleg így tovább tudjuk növelni a transzformáns törzsek asztaxantin termelését.

\subsection{A $c r t W$ és a carRP gének fúziója, valamint a carRP gén elrontása}

A gpdl promóter és terminális régiókra alapozott expressziós rendszerek mellett olyan vektort is építettünk, amelyben megkíséreltük összehangolni a Paracoccus sp. N81106 törzs $\beta$-karotin ketolázt kódoló génjének expresszióját a Mucor karotinbioszintézis gének kifejeződésével. Ilyen vektor a pPT72, ahol a $c r t W$ gént összeépítettük a M. circinelloides fitoén szintáz/likopin cikláz aktivitásért felelős carRP génjével. A carRP kódolja a $\beta$-karotinszintézis utolsó lépését katalizáló enzimet. A Mucor $\beta$-karotinszintézis multienzimatikus modellje szerint, ez a fehérje transzmembrán régióival a membránba ágyazódik, a szintetizálódó $\beta$-karotin a membrán kettős lipidrétegébe kerül. Ha egy ilyen fúziós fehérje müködöképes lenne, a $\beta$-karotin-asztaxantin átalakulás közvetlenül a $\beta$ karotinszintézis helyén valósulhatna meg. Mucor-okban a karotinbioszintézis gének expressziója fény szabályozása alatt áll (kék fény aktiválja), egy ilyen fúziós génben a crtW aktivitás szabályozása a Mucor génekével összehangolttá válhat. Ugyanakkor a $\beta$ karotinszintézis esetleges változásaiból a multienzimatikus modell helyességére is lehet következtetni. Korábban több olyan expressziós vektort építettek, ahol géneket fúzionáltattak és ezek müködőképesek voltak járomspórás gombákban (Hiramatsu és mtsi. 1990, Houghton-Larsen és mtsi. 2003).

\subsubsection{Expressziós vektorok építése és transzformációs kísérletek}

A pPT72 plazmidot a következőképpen szerkesztettük: a pyrG szelekciós gént EcoRI és SacI enzimekkel kihasítottuk a pEPM901 plazmidból és a pUC18 bakteriális klónozó vektor megfelelő helyére ligáltuk (pPT71). A pPT71 vektor hordozza tehát a Mucor pyrG gént, amely az uracil auxotrófia komplementálásáért felelős. A $\operatorname{crt} W$ és a carRP gént, valamint a carRP promóter régióját pBluescript $\mathrm{SK}+$ plazmidba klónoztuk (pPT58). Végül a pPT71 SmaI és KpnI hasítóhelyei közé építettük a pPT58 plazmid 
EcoRV-KpnI közötti, carRP promóter kontrollja alatt álló $c r t W$-carRP fúziós gént hordozó szakaszát (pPT72, 43. ábra).

Ahhoz, hogy megfigyelhessük a fúziós gén bevitelének következményeit, szükségünk volt egy olyan mutáns törzsre, amelyben a carRP nem fejeződik ki. Az ilyen $\operatorname{carR} P^{-}$mutánsok fehér színủek, mivel nem termelnek $\beta$-karotint. Ha egy ilyen $\operatorname{car} R P^{-}$ törzset pPT72 plazmiddal transzformálnánk, csak akkor termelődne $\beta$-karotin és/vagy annak oxigenált származékai, ha a $c r t W$-carRP fúziós gén müködőképes lenne. Így a $c r t W$ carRP müködését a transzformánsok színe jelezni tudja (fehér: a gén nem müködik, sárga: csak $\beta$-karotin termelődik, narancs/rózsaszín: $\beta$-karotin ketoláz aktivitás is jelen van). A carRP $P^{-}$mutáns létrehozásához integratív transzformációra alkalmas vektort szerkesztettünk, amely szelekciós markerként a leuA gént hordozta (pPT75 vektor, 43. ábra). Ehhez a carRP gént és határoló szekvenciáit pUC18 vektorba klónoztuk (pPT73), majd a carRP génben található XhoI-NaeI fragmentumot kivágtuk és helyére beépítettük a pAVB107 plazmidból XhoI-SmaI enzimekkel kivágott, a leuA gént tartalmazó fragmentumot. A pPT75 plazmidból a leuA gént hordozó lineáris fragmentumot AatII és NotI resrtrikciós enzimekkel vágtuk ki (pPT75lf). A transzformációt ezzel a lineáris fragmentummal végeztük, de többszöri próbálkozás után sem nyertünk transzformánsokat. Ezidáig Navarro és mtsi. (2001) írtak le sikeres génkiütést járomspórás gombáknál ( $\operatorname{crg} A$ nullmutáns létrehozása). Mindezek alapján úgy döntöttünk, hogy a pPT72 cirkuláris vektorral az MS12 (carRP $\left.P^{+}\right)$törzset transzformáljuk.
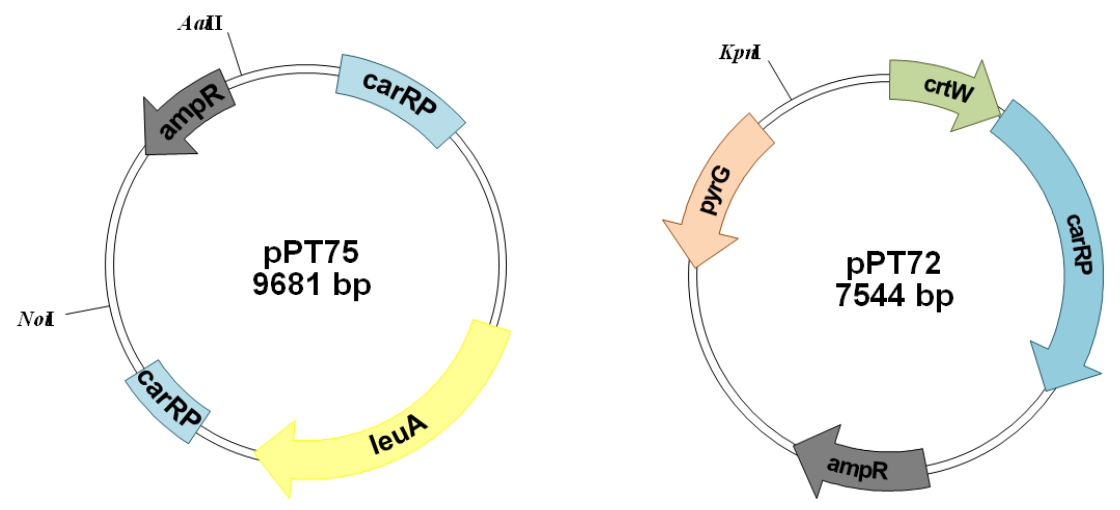

43. ábra. A pPT75 és pPT72 vektorok.

\subsubsection{Cirkuláris plazmidokkal nyert transzformánsok elemzése}

A transzformációs gyakoriság a korábban leírtak szerint alakult: 25-30 telepet izoláltunk $10^{5}$ protoplaszt és $10 \mu \mathrm{g}$ DNS alkalmazása mellett. Meglepő volt azonban a transzformánsok színe, mivel fehér és sárga telepeket egyaránt izoláltunk (44. ábra). 
Amikor a fehér és sárga transzformáns telepeket tisztítani próbáltuk, a sárga telepek továbboltása során sárga telepeket nyertünk, azonban a fehér színűek többszöri szelektálás után is további sárga és fehér telepekre szegregáltak. Feltételeztük, hogy ez a plazmid kópiaszám ingadozásából eredhet, a fúziós fehérje gátolja a Mucor CarRP működését, ami fehér telepeket eredményez.

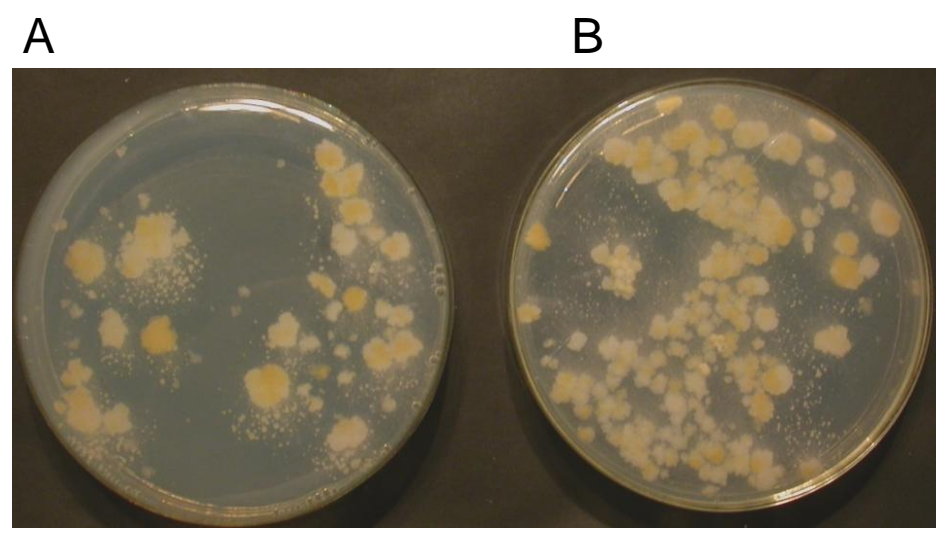

44. ábra. Transzformáció után izolált fehér és sárga telepek (A). Fehér színű telepek többszöri továbboltás után is fehér és sárga telepekre szegregáltak (B).

A qPCR adatok igazolták a feltevésünket: a sárga telepekben nagyon alacsony volt a pPT72 plazmid kópiaszáma (0,002-0,17 kópia/genom között ingadozott), míg a fehér telepekben magas volt (1,6-2 kópia/genom). A transzformánsok karotinoid termelésében is jelentős különbségeket tapasztaltunk: a sárga telepekben magasabb, a fehérekben viszont nagyon alacsony karotinoid-tartalmat mértünk. A transzformánsokban nagyon kis mennyiségben, de kimutatható volt kantaxantin és ehinenon jelenléte is (12. táblázat). Ez azt jelzi, hogy a crtW gén ugyan kifejeztethető egy ilyen génfúzió alkalmazásával, de a kis mennyiségü prekurzorok jelenléte miatt (mivel feltételezhetően a fúziós fehérje gátolja a CarRP müködését) az oxigenált karotinoidok koncentrációja nagyon alacsony marad.

\begin{tabular}{|c|c|c|c|c|c|c|c|c|c|}
\hline Törzs & Likopin & $\begin{array}{c}\boldsymbol{\beta} \text { - } \\
\text { karotin }\end{array}$ & $\begin{array}{c}\boldsymbol{\gamma} \text { - } \\
\text { karotin }\end{array}$ & $\begin{array}{c}\boldsymbol{\beta} \text { - } \\
\text { kriptoxantin }\end{array}$ & Zeaxantin & Kantaxantin & Ehinenon & Asztaxantin & Összkarotinoid \\
\hline MS12 & $6(2)$ & $\begin{array}{c}259 \\
(65)\end{array}$ & $14(4)$ & $29(7)$ & $6(2)$ & - & - & - & 399 \\
\hline $\begin{array}{c}\text { MS12+ } \\
\text { pPT2 } \\
\text { sárga }\end{array}$ & $10(2)$ & $\begin{array}{c}274 \\
(50)\end{array}$ & $19(4)$ & $31(6)$ & $1(0,2)$ & $1,7(0,3)$ & $7(1)$ & - & 553 \\
\hline $\begin{array}{c}\text { MS12+ } \\
\text { pPT72 } \\
\text { fehér }\end{array}$ & $2(2)$ & $34(32)$ & $5(4)$ & $9(8)$ & $2(2)$ & $2(2)$ & $5(5)$ & - & 108 \\
\hline
\end{tabular}

12. táblázat. Eltérő színű pPT72 transzformánsok átlag karotinoid termelése. A karotinoid mennyiségek $\mu \mathrm{g} / \mathrm{g}$ szárazanyagtartalomra vonatkoztatva vannak feltüntetve. Zárójelben az egyes karotinoidok százalékos aránya látható. 


\section{7. ÖSSZEFOGLALÁS}

A járomspórás gombák nagy gyakorlati jelentőséggel bírnak orvosi, iparibiotechnológiai és mezőgazdasági szempontból is. Egyes fajok, mint zigomikózist okozó opportunista patogének érdemelnek figyelmet, mások genetikai modellorganizmusok, illetve számos faj akad közöttük, amelyeket a biotechnológiai iparban hasznosítanak.

A karotinoidok a természetben elöforduló egyik leggyakoribb pigmentcsoport. Alapvető szerepük van mind fotoszintetizáló, mind heterotróf szervezetekben. Régóta ismert antioxidánsok, újabban daganatos megbetegedésekkel szembeni védő és az immunrendszert erősítő hatásukat is kimutatták. A karotinoidokat elsősorban az élelmiszera kozmetikai- és a gyógyszeripar területén, valamint az állattenyésztés során (takarmány kiegészítőként) használják fel jelentősebb mennyiségben. A legnagyobb mennyiségben előállított és forgalmazott karotinoid a $\beta$-karotin (mely egyben a járomspórás gombák által szintetizált karotinoidok közül is a legjelentősebb). Ugyanakkor az utóbbi években mind az ipar, mind az alapkutatás egyre növekvő érdeklődést mutat a $\beta$-karotin oxigenált származékainak (xantofillok), különösen a piros színű keto-származékok bioszintézise iránt is.

A járomspórás gombák, különösen a Phycomyces, a Blakeslea és a Mucor nemzetségek tagjai, régóta használt modellorganizmusai a karotin-bioszintézis biokémiai és genetikai tanulmányozásának. A Mucor fajok közül részletesebben a $M$. circinelloides karotinoid bioszintézisét tanulmányozzák. Ez a gomba rendelkezik néhány, mind a bioszintetikus út vizsgálata, mind a lehetséges alkalmazások szempontjából is rendkívül előnyös tulajdonsággal. Ilyen pl. a hatékony genetikai transzformáció lehetősége, a heterológ gének kifejeződése, vagy a morfológiai dimorfizmus jelensége. A genetikai vizsgálatok, módosítások során nehézséget jelent a cönocitikus micéliális felépítés, illetve a bejuttatott idegen DNS extrakromoszómális elemként való fenntartása, azaz az integráció hiánya. Nagyon kevés ismerettel rendelkezünk továbbá a járomspórás gombákba bejuttatott transzformáló DNS sorsát illetően, pedig ezen ismeretek megkönnyíthetnék az iparban is használható mutáns törzsek elöállítását.

A kutatási program célkitüzései és az elvégzett vizsgálatok eredményei.

A transzformációs kísérletek során a $M$. circinelloides MS12 leucin és uracil auxotróf mutáns törzsét használtuk. 


\section{A Paracoccus sp. N81106 törzs $\beta$-karotin hidroxilázt kódoló crtZ és $\beta$ -} karotin ketolázt kódoló $c r t W$ gének heterológ expressziója $M$. circinelloides-ben.

A Paracoccus sp. N81106 törzs tengeri baktérium crtZ és crtW génjeit $M$. circinelloides glicerinaldehid-3-foszfát dehidrogenázt kódoló gpdl gén szabályozó régióival építettük össze, amelyekkel külön-külön és párban is transzformáltuk az MS12 törzset. Northern hibridizációval igazoltuk, hogy a gének kifejeződnek a gombában. A transzformánsok karotin termelésének vizsgálata során igazoltuk, hogy az MS12 törzs rendelkezik $\beta$-karotin hidroxiláz aktivitással, ezért csak a $\beta$-karotin ketolázt kódoló crt $W$ génre van szükség asztaxantin, kantaxantin, ehinenon, valamint egyéb ketolált karotinoidok termeltetéséhez. A crtW gént hordozó transzformáns törzseknél, illetve a kotranszformánsoknál a vad típusú törzshöz képest megváltozott karotin-összetételt tapasztaltunk, mivel nagy mennyiségben termeltek kantaxantint, ehinenont és kis mennyiségben asztaxantint is.

\section{Az izoprén bioszintézis út génjeinek túlmüködtetése $M$. circinelloides-ben, a} transzformánsok karotin termelésének és a bejuttatott idegen DNS sorsának elemzése.

Klónoztuk és jellemeztük a $M$. circinelloides izopentenil-pirofoszfát izomerázt kódoló ipi génjét. A transzformációs kísérletek során a Velayos és mtsi. (2003, 2004) által klónozott és jellemzett farnezil-pirofoszfát szintázt kódoló isoA és a geranilgeranilpirofoszfát szintázt kódoló $\operatorname{carG}$ géneket is felhasználtuk. A három gént expressziós vektorokba építettük. A vektorok a leucin auxotrófiát komplementáló leuA vagy az uracil auxotrófiát komplementáló pyrG szelekciós markergéneket hordozták. Minden kombinációban elkészítettük a transzformáló vektorokat, hogy az izoprén bioszintézis út egy-egy génjét hordozó plazmidokkal páronként kotranszformációt is tudjunk végezni. A három izoprén gént $M$. circinelloides gpdl génjének szabályozó régióival is összeépítettük, mivel a gpdl gén promótere erősen kifejeződő és indukálható a táptalaj glükóz koncentrációjának fokozásával.

Southern hibridizációs vizsgálatokkal igazoltuk, hogy a transzformáns törzsek autonóm replikálódó elemekként tartják fenn a plazmidokat. Több transzformáns törzs esetében igazoltuk, hogy történtek plazmid DNS átrendeződések is. Valós idejü PCR segítségével igazoltuk, hogy a három gén egy kópiában van jelen a vad típusú Mucor genomban. Vizsgáltuk a transzformánsokba bejuttatott transzformáló plazmidok kópiaszámát is. Átlagosan 2-3 plazmid/genom (0,3-7 plazmid/genom értékek között ingadozott) relatív kópiaszámot mértünk, amely az irodalmi adatokhoz képest magasnak mondható. Több kotranszformáns esetében a plazmidok egyenlőtlen eloszlását mértük. 
Meghatároztuk az MS12 törzs három izoprén génjének transzkripció változását a tenyésztési idő és a glükóz koncentráció függvényében. Meghatároztuk a transzformánsokban túlmüködtetett gének expressziós szintjét és igazoltuk azok növekedését a vad típusú törzshöz képest. Megállapítottuk, hogy a gpdl promóter szabályozása alatt álló géneket hordozó vektorokkal transzformált törzsek esetén a nagyobb glükóz koncentráció a gének transzkripciójának növekedését okozza, ami 1,5 nap után intenzívebb volt, mint 4 nap után.

A mérési körülmények optimalizálása után a karotintermelést spektrofotometriás, TLC és HPLC vizsgálatokkal is meghatároztuk. A transzformánsok karotin termelésében egyértelmü növekedést tapasztaltunk. A legnagyobb mértékű növekedés minden esetben azoknál a törzseknél volt mérhető, melyeket a carG gént hordozó vektorral transzformáltunk. A kotranszformánsok között voltak, amelyekben a három-négyszeresére nőtt a karotintermelés a vad típusú törzshöz képest. A transzformánsok karotinösszetételében nem tapasztaltunk eltérést.

A crtW gént hordozó vektort a gpdl szabályozó régióival összeépített izoprén bioszintézis út génjeit hordozó vektorokkal párban is transzformáltuk, ahol jelentős mértékü xantofilltermelés-növekedést mértünk a csak a pPT51 vektort hordozó transzformánsokhoz képest. Igazoltuk, hogy a kotranszformánsok a heterológ gént hordozó vektorokat autonóm replikálódó elemekként, jelentősen alacsonyabb kópiaszámban $(0,07$ 0,8 kópia/genom) hordozták, mint a homológ géneket hordozó vektorokat (2-7 kópia/genom). Valós idejü PCR segítségével igazoltuk a heterológ gének expresszióját a transzformánsokban. Igazoltuk, hogy minden transzformáns stabil szelektív és nem szelektív körülmények között egyaránt.

\section{A crtW gén integrációja a $M$. circinelloides genomjába különbözö,} integrációt eredményező módszerekkel.

A crtW gént három különböző, integrációt eredményező transzformációs módszerrel juttattuk a $M$. circinelloides genomjába: a kettős rekombináción alapuló szubsztitúcióval, a restrikciós enzim-mediált integrációval (REMI), valamint az Agrobacterium tumefaciens-közvetített transzformációval (ATMT). Vektorokat szerkesztettünk, melyekkel a körülmények optimalizálása után sikeres transzformációt hajtottunk végre mindhárom módszerrel. Az ATMT nem, de a másik két módszer stabil transzformánsokat is eredményezett.

$\mathrm{Az}$ integrációt minden esetben Southern hibridizációs technikával igazoltuk. Vizsgáltuk a genomba történő integráció helyét is inverz-PCR technika segítségével. A transzformáns törzsek karotin termelését is analizáltuk, mely során olyan törzseket sikerült 
izolálnunk, melyek nagy mennyiségű xantofillt, azon belül is kantaxantint és ehinenont termelnek. Ezekben a törzsekben a crtW gén relatív kópiaszáma nagyon magasnak bizonyult, ami vagy a lineáris fragmentumok összekapcsolódását követő integráció vagy a pontatlan kivágódás következtében létrejött cirkuláris DNS felszaporodásának következménye. Ezeket a törzseket vizsgáltuk különböző hőmérsékleten, fényforráson, különböző szénforrást tartalmazó táptalajon, valamint egyéb adalékanyagokkal kiegészített táptalajon tenyésztve. Sikerült meghatároznunk olyan tenyésztési paramétereket, amelyek mellett a $\beta$-karotin - kantaxantin konverzió szinte teljesen megtörtént. Ugyanakkor elhanyagolható volt a termelt asztaxantin mennyisége, valószínüleg a $M$. circinelloides $\beta$ karotin hidroxiláza nem vagy csak kis hatásfokkal képes a kantaxantint szubsztrátként hasznosítani. Az asztaxantintermelés fokozása érdekében két transzformáns törzsbe bejuttattuk a crtZ gént hordozó vektort autonóm replikálódó cirkuláris plazmidon. Ezekben a transzformánsokban már jelentős mennyiségben termelődött asztaxantin.

Szerkesztettünk egy, a $c r t W$-carRP fúziós gént hordozó vektort is. Ezt a vektort hordozó transzformánsok azonban nem vagy csak kis mértékben termeltek karotinokat.

A kutatások eredményeként új információkkal bővültek ismereteink az eddig kevéssé tanulmányozott járomspórás gombák transzformációs rendszereit és karotinoid bioszintézisét illetően. Számos megváltozott karotinoid-összetételü, valamint megnövekedett karotintermelő képességű gombatörzset hoztunk létre. 


\section{SUMMARY}

Zygomycetes fungi have great practical importance in medical, industrial biotechnological and agricultural aspects. Some species are considered as opportunistic pathogens causing zygomycosis, others are known as model-organisms in genetic studies and several species are used in the biotechnological industry.

Carotenoids are yellow to orange-red natural pigments with a broad range of biological functions. They play an important role in photosynthetic and heterotrophic organisms. Their effective antioxidant property linked to a preventive action on various types of cancer and an enhancement of the immune response makes them important in the human diet. Carotenoids are used in the food, pharmaceutical and cosmetic industries and as feed colour additives (especially to salmon, trout and poultry). The main industrial carotenoid is $\beta$-carotene, but the production of lycopene and astaxanthin is also considerable. Today most of the carotenoid are produced by chemical methods, but there is an increasing interest for sources of carotenoids of biological origins. The demand to decrease the amounts of chemical additives urges the development of the biological production.

Today, both applied and basic researches are increasingly directed towards the oxygenated derivatives of the $\beta$-carotene (xanthophylls), especially to the biosynthesis of the red keto-derivatives.

Zygomycetes, especially the members of the genera Phycomyces, Blakeslea and Mucor have been used as model-organism for the study of the genetic and biochemical background of the carotenoid biosynthesis. From the Mucor genus the carotenoid biosynthesis of the Mucor circinelloides is the most studied. This fungus has some advantageous features in reference to molecular studies and biotechnological applications, such as the possibility of the genetic transformation, the expression of heterologous genes or the morphological dimorphism. Some properties of zygomycetes make the genetic analysis or modification difficult, like the coenocytic mycelial structure, or the extrachromosomal maintenance of the foreign DNA.

\section{Objectives of the research program and the results of the experiments.}

The leucine and uracil double auxotrophic mutant Mucor circinelloides MS12 strain was used in the transformation experiments. 
1. Heterologous expression of the Paracoccus sp. N81106 strain crtZ ( $\beta$ carotene hydroxylase) and $c r t W$ genes ( $\beta$-carotene ketolase) in M. circinelloides.

The $\operatorname{crt} Z$ and $\operatorname{crt} W$ genes of the marine Paracoccus sp. N81106 strain were placed between the M. circinelloides gpdl (encoding the glyceraldehyde-3-phosphate dehydrogenase) regulatory regions. Transformation and co-transformation experiments with the two genes were also performed. The expression of the heterologous genes in the fungus was verified by Northern hybridization. The $\beta$-carotene hydroxylase activity of the MS12 strain was demonstrated, thus, expression of the $c r t W$ gene encoding the $\beta$-carotene ketolase seems to be enough to produce astaxanthin, canthaxanthin and other ketolated $\beta$ carotene derivatives. The changes in the composition of the accumulated carotenoids in the transformants harbouring the $c r t W$ gene comparing to the wild type strain were analysed; production of canthaxanthin, echinenone in high amount and astaxanthin in low amount was verified.

2. Overexpression of the isoprenoid biosynthetic genes in M. circinelloides, analysis of the carotenoid production of the transformants and the fate of the introduced DNA.

The isopentenyl pyrophosphate isomerase, encoding the ipi gene of $M$. circinelloides was cloned and characterized. Velayos and his research group have cloned and characterized the $M$. circinelloides isoA gene encoding the farnesyl pyrophosphate synthase and the $c a r G$ gene encoding the geranylgeranyl pyrophosphate synthase. These genes and the ipi were used in our experiments. The expression vectors harbouring these genes carried one of the following selection marker genes too: the leuA ( $\alpha$-isopropyl malate isomerase) complementing the leucine auxotrophy or the pyrG (5'-monophosphate decarboxylase) complementing the uracil auxotrophy. The expression vectors were built in two versions containing one of these two selection markers to allow co-transformations with two plasmids. The three isoprenoid biosynthesis genes were also placed under the control of promoter and terminal regions of the M. circinelloides gpdl gene. This promoter is very effective and its activity depends on the concentration of glucose. Transformations and the co-transformations with two plasmids (to test all possible gene combinations) were achieved with PEG-mediated protoplast transformation.

Southern hybridization technique was used to verify that the transformants carried the introduced DNA as autonomously replicating elements. Plasmid rearranges were detected in many of the transformants. Quantitative PCR (qPCR) technique was used to verify that the three isoprenoid genes are in a single copy in the wild type Mucor genome. The copy number of the plasmids in the transformants was also analysed. The average 
relative copy number was 2-3 copies/genome (varied between 0.3-7 copies/genome), which is a high number comparing with other publications. The copy number of the two plasmids was different in most of the co-transformants.

The time and glucose concentration dependence of transcription of the isoprenoid genes was measured in the MS12 strain. The increase in the transcription level of the introduced genes was confirmed in the transformants. Increased expression of the genes driven by the gpdl promoter was verified in cultures on media containing higher glucose concentration.

After optimization of the parameters, spectrophotometry and TLC and HPLC techniques were used for the analysis of the carotenoid production. The increase of the carotenoid production in the transformants was proved. Transformants carrying the $\operatorname{car} G$ gene in extra copies showed the highest carotenoid accumulation. Some of the cotransformants produced three to four times more carotenoids, than the wild type strain. No significant changes were detected in the composition of the produced carotenoids in the transformants in comparison with the wild type strain.

Co-transformations of the MS12 with the plasmid harbouring the $\operatorname{crtW}$ gene and the plasmids carrying one of the isoprenoid biosynthesis pathway genes placed under the control of the gpdl regulatory regions were also performed in all possible combinations. In such transformants, increased xanthophyll production was detected comparing to strains transformed only with the $c r t W$ gene-containing plasmid. These transformants carried the plasmids as autonomously replicating elements, but the copy number of the plasmids containing the bacterial gene were significantly lower (varied between 0.07-0.8 copies/genome), than the vectors containing the homologous genes (varied between 2-7 copies/genome). Real-time qPCR technique was used to analyse the expression of the heterologous genes.

All of the transformants proved to be stable under selective and non-selective conditions.

\section{Integration of the $c r t W$ gene into the $M$. circinelloides genome using different}

\section{methods.}

We achieved the integration of the bacterial $c r t W$ gene into the $M$. circinelloides genome using the following different methods: gene substitution based on double crossing over; restriction enzyme-mediated integration (REMI) and Agrobacterium tumefaciensmediated transformation (ATMT). After the optimization of the transformation conditions, successful transformations were performed with all of the constructed vectors. With the exception of the ATMT method, stable transformants were isolated in each experiment. 
Southern hybridization technique was used to verify the integration and inversePCR to determine the site of the integration. The carotenoid production of the transformants was analysed and several mutant strains producing xanthophylls in high amounts (mainly canthaxanthin and echinenone) were isolated. In these strains the crtW gene was detected in extremely high copy number; maybe originating from the integration of the linear fragment in tandem repeats or from the imprecise excision, recircularization and extrachromosomal amplification of the introduced DNA. These strains were cultured under different conditions, e.g. different temperatures, light sources, media containing different carbon sources and supplemented with different chemical additives. Several culture conditions, where the $\beta$-carotene-canthaxanthin conversion was nearly complete, were determined for these strains. Furthermore, production of astaxanthin was near to zero in these strains. Maybe the $\beta$-carotene hydroxylase of $M$. circinelloides is able to use the canthaxanthin as substrate only with very low efficiency. For this reason, the autonomously replicating plasmid carrying the $\operatorname{crt} Z$ gene was used for the transformation of two of the canthaxanthin-producing mutants. As a result, astaxanthin production in high amount was detected in these strains.

A plasmid carrying the crtW-carRP gene fusion was also built and used for the transformation of the MS12 strain, but these transformants produced low amount of carotenoids.

As a result of our research, new information is standing in the poorly studied transformation systems and carotenoid biosynthesis in Zygomycetes. Many Mucor strains changed in their carotenoid production have been isolated. New strains with significantly increased carotenoid production were also created and characterized. 


\section{IRODALOMJEGYZÉK}

Albrecht M., Misawa N., SAndmann G. (1999) Metabolic engineering of the terpenoid biosynthetic pathway of Escherichia coli for production of the carotenoids $\beta$ carotene and zeaxanthin. Biotechnol. Lett. 21: 791-795.

AlmeidA E.R.A., CERDÁ-Olmedo E. (2008) Gene expression in the regulation of carotene biosynthesis in Phycomyces. Curr. Genet. 53: 129-137.

Álvarez V., RodríGuez-SÁiz M., DE la Fuente J.L., Gudina E.J., Godio R.P., Martín J.F., BARREDO J.L. (2006) The crtS gene of Xanthophyllomyces denrorhous encodes a novel cytochrome-P450 hydroxylase involved in the conversion of $\beta$-carotene into astaxanthin and other xanthophylls. Fungal Genet. Biol. 43: 261-272.

AN G.H., CHANG K.W., JOHNSON E.A. (1996) Effect of oxygen radicals and aeration on carotenogenesis and growth of Phaffia rhodozyma (Xanthophyllomyces dendrorhous). J. Microbiol. Biotechnol. 6: 103-109.

ANAYA N., RONCERO M.I. (1991) Transformation of a methionine auxotrophic mutant of Mucor circinelloides by direct cloning of the corresponding wild type gene. Mol. Gen. Genet. 230: 449-455.

Ando A., SAKURAdANi E., HorinaKa K., OGaWA J., SHimizU S. (2009a) Transformation of an oleaginous zygomycete Mortierella alpina $1 \mathrm{~S}-4$ with the carboxin resistance gene conferred by mutation of the iron-sulfur subunit of succinate dehydrogenase. Curr. Genet. 55 (3): 349-356.

Ando A., Sumida Y., Negoro H., Suroto D.A., Ogawa J., Sakuradani E., Shimizu S. (2009b) Establishment of Agrobacterium tumefaciens-mediated transformation of an oleaginous fungus, Mortierella alpina $1 \mathrm{~S}-4$, and its application for eicosapentaenoic acid producer breeding. Appl. Environ. Microbiol. 75 (17): 55295535.

APPEL K.F., WolfF A.M., ARNAU J. (2004) A multicopy vector system for genetic studies in Mucor circinelloides and other zygomycetes. Mol. Gen. Genet. 271 (5): 595-602.

Armstrong G.A., HEARst J.E. (1996) Carotenoids2: Genetics and molecular biology of carotenoid pigment biosynthesis. FASEB J. 10: 228-237.

ArMSTRONG G.A.(1997) Genetics of eubacterial carotenoid biosynthesis: a colorful tale. Annu. Rev. Microbiol. 51: 629-659.

ARNAU J., JEPSEN L.P., STROMAN P. (1991) Integrative transformation by homologous recombination in the zygomycete Mucor circinelloides. Mol. Gen. Genet. 225: 193198.

Arnau J., Murillo F.J., Torres-Martinez S. (1988) Expression of Tn5-derived kanamycin resistance in the fungus Phycomyces blakesleeanus. Mol. Gen. Genet. 212: 375-377.

Arnau J., Stroman P. (1993) Gene replacement and ectopic integration in the zygomycete Mucor circinelloides. Curr. Genet. 23: 542-546.

Arrach N., Fernández-Martín R., CerdÁ-Olmedo E., Avalos J. (2001) A single gene for lycopene cyclase, phytoene synthase, and regulation of carotene biosynthesis in Phycomyces. Proc. Natl. Acad. Sci. USA 98: 1687-1692.

ARrach N., Schmidhauser T.J., Avalos J. (2002) Mutants of the carotene cyclase domain of al-2 from Neurospora crassa. Mol. Genet. Genomics 266: 914-921.

ASHBY M.N., EDWARDS P.A. (1990) Elucidation of the deficiency in two yeast coenzyme Q mutants. Characterization of the structural gene encoding hexaprenyl pyrophosphate synthetase. J. Biol. Chem. 265: 13157-13164. 
ATAMANYUK D.I., RAZUMORSKII P.N. (1974) Effect of ammonium perchlorate on carotene formation by Rhodotorula gracilis K-1. Ser. Biol. Khim. Nauk. 1: 89-90.

BALLANCE D.J. (1990) Transformation systems for filamentous fungi and an overview of fungal gene structure. Molecular Industrial Mycology. Leong S.A., Berka R.M. (ed.), Dekker, New York, pp. 1-29.

BARR D.J.S. (1992) Evolution and kingdoms of organisms from the perspective of a mycologist. Mycologia 62: 1-11.

BARTSCH S., SCHIMEK C., WÖSTEMEYER J. (2002) Microprojectile bombardment as a reliable method for transformation of the mucoralean fungus Absidia glauca. Mycoscience 43: 213-217.

BEGGS J.D. (1978) Transformation of yeast by a replicating hybrid plasmid. Nature 275: 104-109.

Benito E.P., Díaz-Minguez J.M., IturRiaga E.A., CAmpuzano V., Eslava E.P. (1992) Cloning and sequence analysis of the Mucor circinelloides pyrG gene encoding orotidine-5'-monophosphate decarboxylase: use of $p y r G$ for homologous transformation. Gene 116: 59-67.

Benito E.P., Campuzano V., LôPez-Matas M.A., De Vicente J.I., Eslava A.P. (1995) Isolation, characterization and transformation, by autonomous replication, of Mucor circinelloides OMPdecase-deficient mutants. Mol. Gen. Genet. 248 (2): 126-135.

Benny G.L., Humber R.A., Morton J.B. (2001) Zygomycota: Zygomycetes. Systematics and Evolution. The Mycota. McLaughlin D.J., McLaughlin K.G., Lemke P.A. (ed.), Springer-Verlag, Berlin, Heidelberg, Vol. VII PartA, pp. 113-146.

BENNY G.L. (2001) Zygomycota: Trichomycetes. Systematics and Evolution. The Mycota. McLaughlin D.J., McLaughlin K.G., Lemke P.A. (ed.), Springer-Verlag, Berlin, Heidelberg, Vol. VII PartA, pp. 147-160.

BHOSALE P. (2004) Environmental and cultural stimulants in the production of carotenoids from microorganisms. Appl. Microbiol. Biotechnol. 63: 351-361.

Bhosale P., Bertnstein P.S. (2005) Microbial xanthophylls. Appl. Microbiol. Biotechnol. 68(4): 445-455.

BoussiBA S. (2000) Carotenogenesis in the green alga Haematococcus pluvialis: cellular physiology and stress response. Physiol. Plant. 108: 111-117.

BOUSSIBA S., FAN L., VONSHAK A. (1992) Enhancement and determination of astaxanthin accumulation in green alga Haematococcus pluvialis. Method. Enzymol. Packer L. (ed.) 214: 386-391.

BRITTON G. (1983) The biochemistry of natural pigments. Cambridge University Press, Cambridge, UK.

BRITTON G. (1998) Overview of carotenoid biosynthesis. Carotenoids: biosynthesis and metabolism. Britton G., Liaaen-Jensen S., Pfander H. (ed.), Birkhäuser-Verlag, Basel, Switzerland, Vol. III, pp. 13-140.

Britton G., LiaAn-Jensen S., Pfander H. (2008) Carotenoids. Natural function. Birkhäuser-Verlag, Basel-Boston-Berlin, Switzerland, Vol. 4.

BROWN T.A. (1991) Molecular biology labfax. BIOS Scientific Publisher, Blackwell Scientific Publications, St Thomas House, Oxford, UK.

Bundock P., DEN DulK-RAS A., BeiJersbergen A., HooykaAs P.J.J. (1995) Transkingdom T-DNA transfer from Agrobacterium tumefaciens to Saccharomyces cerevisiae. EMBO J. 14: 3206-3214.

BundOCK P., HoOYKAAS P.J.J. (1996) Integration of Agrobacterium tumefaciens T-DNA in the Saccharomyces cerevisiae genome by illegitimate recombination. Proc. Natl. Acad. Sci. USA 93: 15272-15275. 
Burke C., CROTEAU R. (2002) Interaction with the small subunit of geranyl diphosphate synthase modifies the chain length specificity of geranylgeranyl diphosphate synthase to produce geranyl diphosphate. J. Biol. Chem. 277: 3141-3149.

BURMESTER A., WÖSTEMEYER A., WÖSTEMEYER J. (1990) Integrative transformation of a zygomycete, Absidia glauca, with vectors containing repetitive DNA. Curr. Genet. 17: 155-161.

Burmester A., Wöstemeyer A., ARnAu J., WÖstemeyer J. (1992) The SEG1 element: a new DNA region promoting stable mitotic segregation of plasmids in the zygomycete Absidia glauca. Mol. Gen. Genet. 235: 166-172.

BURMESTER A. (1992) Transformation of the mycoparasite Parasitella simplex to neomycin resistance. Curr. Genet. 21: 121-124.

Burton G.W. (1989) Antioxidant action of carotenoids. J. Nutrition 119: 109-111.

CAmbareri E.B., Singer M.J., Selker E.U. (1991) Recurrence of repeatinduced point mutation (RIP) in Neurospora crassa. Genetics 127: 699-710.

Cantrell A., McGarvey D.J., Truscott T.G., Rancan F., BöHm F. (2003) Singlet oxygen quenching by dietary carotenoids in a model membrane environment. Arch. Biochem. Biophys. 412 (1): 47-54.

Carattoli A., Cogoni C., Morelli G., Macino G. (1994) Molecular characterization of upstream regulatory sequences controlling the photo induced expression of the albino-3 gene of Neurospora crassa. Mol. Microbiol. 13: 787-795.

CARTER J.P. (1988) Gamma-linoleic acid as a nutrient. Food Technol. 6: 72-82.

Casas-Flores S., Rosales-SaAvedra T., Herrera-Estrella A. (2004) Three decades of fungal transformation: novel technologies. Methods Mol. Biol. 267: 315-325.

Cerdé-Olmedo E. (2001) Phycomyces and the biology of light and color. FEMS Microbiol. Rev. 25: 503-512.

Cerdá-Olmedo E., Avalos J. (1994) Oleaginous fungi: carotene-rich oil from Phycomyces. Prog. Lipid Res. 33 (1-2): 185-192.

Chayakulkeeree M., Ghannoum M.A., Perfect J.R. (2006) Zygomycosis: the reemerging fungal infection. Eur. J. Clin. Microbiol. Infect. Dis. 25: 215-229.

Chen X., Stone M., Schlagnhaufer C., Romaine P.C. (2000) A fruiting body tissue method for efficient Agrobacterium-mediated transformation of Agaricus bisporus. Appl. Environ. Microbiol. 66 (10): 4510-4513.

CHEW B.P. (1993) Role of carotenoids in the immune response. J. Dairy Sci. 76: 28042811.

CheW B.P., PARK J.S., Wong M.W., Wong T.S. (1999) A comparison of the anticancer activities of dietary $\beta$-carotene, canthaxanthin and astaxanthin in mice in vivo. Anticancer Res. 19: 1849-1853.

Choi H.T., Revuelta J.L., SAdHU C., Jayaram M. (1988) Structural organization of the TRP1 gene of Phycomyces blakesleeanus: implications for evolutionary gene fusions in fungi. Gene 71: 85-95.

CIEgler A. (1965) Microbial carotenogenesis. Adv. Appl. Microbiol. 7: 1-34.

COVERT S.F., KAPOOR P., LeE M., BRILEY A., NAIRN C.J. (2001) Agrobacterium tumefaciens-mediated transformation of Fusarium circinatum. Mycol. Res. 105: 259-264.

CSERnetics Á., Linka B., Krisch J., VÁGVÖlgyi Cs., PAPP T. (2007) Increased carotenoid content of Xanthophyllomyces dendrorhous cultivated in plant oil supplemented media. Acta Biol. Szeged 51(1): 43-46.

Csernetics Á., Nagy G., Iturriaga E.A., SzeKeres A., Eslava A.P., VÁgvölgyi Cs., PAPP T. (2011a) Expression of three isoprenoid biosynthesis genes and their effects on the carotenoid production of the zygomycete Mucor circinelloides. Fung. Genet. Biol. 48(7): 696-703. 
Csernetics Á., Nagy G., Bencsik O., Iturriaga E.A., Eslava A.P., VÁgVÖlgyi Cs., PAPP T. (2011b) Canthaxanthin production with modified Mucor circinelloides strains (manuscript). Metabol. Engin.

Csernetics Á., Péteri Zs., LinkA B., TAKÓ M. (2005) Physiological and genetic variability of zygomycetes causing post-harvest decay. Acta Phytopathol. Entomol. Hung. 40: 262-267.

Cunningham JR. F.X., GANTT E. (1998) Genes and enzymes of carotenoid biosynthesis in plants. Annu. Rev. Plant Phys. Plant Mol. Biol. 49: 557-583.

Das A., Yoon S.-H., LEE S.-H., KIM J.-Y., OH D.-K., KIM S.-W. (2007) An update on microbial carotenoid production: application of recent metabolic engineering tools. Appl. Microbiol. Biotechnol. 77: 505-512.

DegefU Y., HANIF M. (2003) Agrobacterium tumefaciens-mediated transformation of Helminthosporium turcicum, the maize leafblight fungus. Arch. Microbiol. 180: 279-284.

De Groot M.J.A., Bundock P., HooykaAs P.J.J., BeiJersbergen A.G.M. (1998) Agrobacterium tumefaciens-mediated transformation of filamentous fungi. Nature Biotechnol. 16: 839-842.

de Haro J.P., Calo S., Cervantes M., Nicolás F.E., Torres-Martínez S., RuizVÁZQUEZ R.M. (2009) A single dicer gene is required for efficient gene silencing associated with two classes of small antisense RNAs in Mucor circinelloides. Eukaryot. Cell. 10: 1486-1497.

Devoyod J.J. (1988) Microbial accidents in cheese making due to Mucor. MicrobiologieAliments-Nutrition 6: 25-29.

Dickinson L., Harboe M., VAN HeEswitck R., Stroman P., LePsen L.P. (1987) Expression of active Mucor miehei aspartic protease in Mucor circinelloides. Carlsberg Res. Commun. 52: 243-252.

Dufossé L., Galaupa P., Yaronb A., Aradb S.M., Blanc P., Murthy K.N.C., RAVISHANKAR G.A. (2005) Microorganisms and microalgae as sources of pigments for food use: a scientific oddity or an industrial reality? Trends Food Sci. Technol. 16: $389-406$.

Dufossé L. (2006) Microbial Production of Food Grade Pigments. Food Technol. Biotechnol. 44(3): 313-321.

Edge R., McGarvey D.J., Truscott T.G. (1997) The carotenoids as anti-oxidants - a review. J. Photochem. Photobiol. B. 41: 189-200.

EISENREICH W., RoHDich F., BACHER A. (2001) Deoxyxylulose phosphate pathway to terpenoids. Trends Plant. Sci. 6: 78-84.

Fazeli M.R., Tofighi H., SAmadi N., Jamalifar H. (2006) Effects of salinity on $\beta$ carotene production by Dunaliella tertiolecta DCCBC26 isolated from the Urmia salt lake, north of Iran. Bioresource Technol. 97: 2453-2456.

FINCHAM J.R.S. (1989) Transformation of fungi. Microbiol. Rev. 53: 148-170.

Finney K.F., Pomeranz Y., Bruinsma B. (1994) Use of algae Dunaliella as a protein supplement in bread. Cereal Chem. 61: 402-406.

Flores-CoterA L.B., SANCHEZ S. (2001) Copper but not iron limitation increases astaxanthin production by Phaffia rhodozyma in a chemically defined medium. Biotechnol. Lett. 23: 793-797.

FRASER P.D., MiURA Y., MiSAWA N. (1997) In vitro characterization of astaxanthin biosynthetic enzymes. J. Biol. Chem. 272 (10): 6128-6135.

GODTFREDSEN S.E. (1990) Microbial lipases. Microbial enzymes and biotechnology. Fogarty W.M., Kelly C.T. (ed.), $2^{\text {nd }}$ ed., Elsevier, London, UK, pp. 255-274.

GonZalez-Hernandez G.A., Herrera-Estrella L., Rocha-Ramirez V., Roncero M.I.G., GUTIERREZ-CORONA J.F. (1997) Biolistic transformation of Mucor circinelloides. Mycol. Res. 101: 953-956. 
GoodAy G.W. (1994) Hormones in mycelial fungi. Growth, Differentiation and Sexuality, The Mycota. Wessels J.G.H., Meinhardt F. (ed.), Vol. I. Springer-Verlag, Berlin, pp. 401-411.

GoodwIN T.W. (1980) The Biochemistry of the Carotenoids, Vol. I., Plants, $2^{\text {nd }}$ ed. Chapman \& Hall, London.

Gu W.-L., AN G.-H., JOHNSON E.A. (1997) Ethanol increases carotenoid production in Phaffia Rhodozyma. J. Ind. Microbiol. Biotechnol. 19: 114-117.

GuERIN M., HunTLEY M.E., OlAizOLA M. (2003) Haematococcus astaxanthin: applications for human health and nutrition. Trends Biotechnol. 21(5): 210-216.

GURR S.J., UNKLES S.E., KINGHORN J.R. (1987) The structure and organisation of nuclear genes of filamentous fungi. Gene Structure in Eukaryotes. Kinghorn J.R. (ed.), IRL Press, Oxford, pp. 93-139.

Halliwell B., GutTeridge J.M.C. (1999) Free Radicals in Biology and Medicine. 3rd ed., Oxford University Press, New York, USA.

HAMilton C.M., FraRY A., Lewis C., TANKSLEy S. (1996) Stable transfer of intact high molecular weight DNA into plant chromosomes. Proc. Natl. Acad. Sci. USA 93: 9975-9979.

Han B.Z., Rombouts F.M., Nout M.J.R. (2001) A Chinese fermented soybean food. Int. J. Food. Microbiol. 65: 1-10.

Hanif M., PARdo A.G., Gorfer M., RAudaskoski M. (2002) T-DNA transfer and integration in the ectomycorrhizal fungus Suillus bovinus using hygromycin B as a selectable marker. Curr. Genet. 41: 183-188.

Hannibal L., Lorquin J., D’Ortoli N.A., Garcia N., Chaintreuil C., Masson-Boivin C., DREYFus B., GIRAUD E. (2000) Isolation and characterization of canthaxanthin biosynthesis genes from the photosynthetic bacterium Bradyrhizobium sp. strain ORS278. J. Bacteriol. 182: 3850-3853.

Hausmann A., Sandmann G. (2000) A single five-step desaturase is involved in the carotenoid biosynthesis pathway to $\beta$-carotene and torulene in Neurospora crassa, Fungal Genet. Biol. 30: 147-153.

Hinnen A., Hick S.J.B., Fink G.R. (1978) Transformation of yeast. Proc. Natl. Acad. Sci. USA 75 (4): 1929-1933.

Hiramatsu R., Yamashita T., Aikawa J., Horinouchi S., Beppu T. (1990) The prepropeptide of Mucor rennin directs the secretion of human growth hormone by Saccharomyces cerevisiae. Appl. Environ. Microbiol. 56(7): 2125-2132.

HoriUChi H., TAKAYA N., YANAi K., NAKAmURA M., OHTA A., TAKAGi M. (1995) Cloning of the Rhizopus niveus pyr4 gene and its use for the transformation of Rhizopus delemar. Curr. Genet. 27: 472-478.

Houghton-Larsen J., Amstrup Pedersen P. (2003) Functional expression of rat adenosine A1 receptor in the dimorphic zygomycete Mucor circinelloides. Appl. Microbiol. Biotechnol. 63: 64-67.

HugHes D.A. (1999) Effects of carotenoids on human immune function. Proc. Nutr. Soc. 58: 713-718.

HÜmbelin M., Thomas A., Lin J., Jore J., BerRy A. (2002) Genetics of isoprenoid biosynthesis in Paracoccus zeaxanthinifaciens. Gene 297: 129-139.

IBRAHIM A.S., SKORY C.D. (2006) Genetic manipulation of zygomycetes. Medical Mycology, Cellular and Molecular Techniques. Kavanagh K. (ed.), New York, NY: John Wiley \& Sons, pp. 305-325.

Ibrahim A.S., Gebremariam T., Lin L., Luo G., Husseiny M.I., Skory C.D., Fu Y., French S.W., EDWARdS JR. J.E., SPEllberg B. (2010) The high affinity iron permease is a key virulence factor required for Rhizopus oryzae pathogenesis. Mol. Microbiol. 77: 587-604. 
IturRiaga E.A., DíAZ-Minguez J.M., Benito E.P., Álvarez M.I., Eslava A.P. (1992) Heterologous transformation of Mucor circinelloides with the Phycomyces blakesleeanus leul gene. Curr. Genet. 21: 215-223.

Iturriaga E.A., PapP T., Breum J., Arnau J., Eslava A.P. (2005) Strain and culture conditions improvement for $\beta$-carotene production in Mucor. Microbial Processes and Products. Methods in Biotechnology. Barredo, J.-L. (ed.), Humana Press, USA, Vol. XVIII, pp. 239-256.

ItURriaga E.A., Velayos A., Eslava A.P. (2000) Structure and function of genes involved in the biosynthesis of carotenoids in the Mucorales. Biotechnol. Bioprocess Eng. 5: 263-274.

Iturriaga E.A., Velayos A., Eslava A.P., Alvarez M.I. (2001) The genetics and molecular biology of carotenoid biosynthesis in Mucor. Recent Res. Dev. Genet. 1: 79-92.

James T.Y., Kauff F., Schoch C.L., Matheny P.B., Hofstetter V. et Al. (2006) Reconstructing the early evolution of Fungi using a six-gene phylogeny. Nature 443: 818-822.

JiN E., LEE C.G., POLLE J.E.W. (2006) Secondary carotenoid accumulation in Haematococcus (Chlorophyceae): biosynthesis, regulation, and biotechnology. $J$. Microbiol. Biotechnol. 16: 821-831.

JoHnson E.A., Schroeder W.A. (1995) Microbial carotenoids. Adv. Biochem. Eng. Biotech. 53: 119-178.

JONES J.D., HOHN T.M., LEATHERS T.D. (2004) Genetically modified strains of Fusarium sporotrichioides for production of lycopene and $\beta$-carotene. Society of Industrial Microbiology Annual Meeting, San Diego, USA, pp. 91.

Jung M.K., OvechKinA Y., PrigozhinA N., OAKLEY C.E., OAKLEY B.R. (2000) The use of beta-D-glucanase as a substitute for Novozym 234 in immunofluorescence and protoplasting. Fung. Genet. Newslett. 47: 65-66.

JyONOUCHI H., ZHANG L., GROSS M., TOMITA Y. (1994) Immunomodulating actions of carotenoids: enhancement of in vivo and in vitro antibody production to Tdependent antigens. Nutr. Cancer 21(1): 47-58.

JyONOUCHI H., Sun S., MizOKAMI M., Gross M.D. (1996) Effects of various carotenoids on cloned, effector-stage T-helper cell activity. Nutr. Cancer 26: 313-324.

KADO C.I. (1991) Molecular mechanisms of crown gall tumorigenesis. Crit. Rev. Plant. Sci. 10: 1-32.

KaJiwara S., FraSer P.D., Kondo K., Misawa N. (1997) Expression of an exogenous isopentenyl diphosphate isomerase gene enhances isoprenoid biosynthesis in Escherichia coli. Biochem. J. 324: 421-426.

Kellog B.A., Poulter C.D. (1997) Chain elongation in the isoprenoid biosynthetic pathway. Curr. Opin. Chem. Biol. 1: 570-578.

KLOTZ L-O., BRIVIBA K., SiES H. (2000) Signaling by singlet oxygen in biological systems. Antioxidant and redox regulation of genes. Sen C., Sies H., Baeuerle P. (ed.), Academic Press, San Diego, California, pp. 3-20.

Kobayashi M.K., Toshinide N.M., NAGai S. (1992) Effects of light intensity, light quality, and illumination cycle on astaxanthin formation in a green alga, Haematococcus pluvialis. J. Ferment. Bioeng. 74: 61-63.

Koncz C., Schell J. (1986) The promoter of the $\mathrm{T}_{\mathrm{L}}$-DNA gene 5 controls the tissuespecific expression of chimeric genes carried by a novel type of Agrobacterium binary vector. Mol. Gen. Genet. 204: 383-396.

Kuzina V., CerdÁ-Olmedo E. (2007) Ubiquinone and carotene production in the Mucorales Blakeslea and Phycomyces. Appl. Microbiol. Biotechnol. 76: 991-999. 
Kuzina V., Domenech C., CerdÁ-Olmedo E. (2006) Relationships among the biosyntheses of ubiquinone, carotene, sterols, and triacylglycerols in Zygomycetes. Arch. Microbiol. 186: 485-493.

LAMPILA L.E., WALlEN S.E., BULleRman L.B. (1985) A review of factors affecting biosynthesis of carotenoids by the order Mucorales. Mycopathologia 90: 65-80.

LARSEN G.G., ApPel K.F., WolfF A.-M., NiElsen J., ARNAU J. (2004) Characterisation of the Mucor circinelloides regulated promoter gpd1P. Curr. Genet. 45: 225-234.

LEE P.C., SCHMIDT-DANNERT C. (2002) Metabolic engineering towards biotechnological production of carotenoids in microorganisms. Appl. Microbiol. Biotechnol. 60: 111.

Li W., GuO G., ZhENG G. (2000) Agrobacterium-mediated transformation : state of the art and future prospect - review. Chin. Science Bull. 45 (17): 1537-1546.

Liang P.-H., Ko T.-P., WANG A.H.-J. (2002) Structure, mechanism and function of prenyltransfrases-review article. Eur. J. Biochem. 269: 3339-3354.

LinNemannstöns P., VoB T., HedDEn P., GASKIn P., TUdZYNSKi B. (1999) Deletions in the gibberellin biosynthesis gene cluster of Gibberella fujikuroi by restriction enzyme-mediated integration and conventional transformation-mediated mutagenesis. Appl. Env. Microbiol. 65: 2558-2564.

LiOU C.M., YANAI K., HORIUCHI H., TAKAGI M. (1992) Transformation of a Leu' mutant of Rhizopus niveus with the leuA gene of Mucor circinelloides. Biosci. Biotechnol. Biochem. 56: 1503-1504.

LIU Y.S., WU J.Y. (2006) Hidrogen peroxide-induced astaxanthin biosynthesis and catalase activity in Xanthophyllomyces dendrorhous. Appl. Microbiol. Biotechnol. 73: 663668.

LiVAK K.J., SchmitTGEN T.D. (2001) Analysis of relative gene expression data using realtime quantitative PCR and the $2^{-\Delta \Delta \mathrm{Ct}}$ method. Methods 25: 402-408.

LóPez-Nieto M.J., Costa J., Peiro E., Mendez E., Rodriguez-SAiz M., De la Fuente J.L., CABRI W., BARREDO J.L. (2004) Biotechnological lycopene production by mated fermentation of Blakeslea trispora. Appl. Microbiol. Biotechnol. 66: 153159.

Lu S., Lyngholm L., Yang G., Bronson C., Yoder O.C., Turgen B.G. (1994) Tagged mutations at the Tox 1 locus of Cochliobolus heterostrophus by restriction enzymemediated integration. Proc. Natl. Acad. Sci. USA 91: 12649-12653.

LuKÁCs GY., PAPP T., SOMOGYVÁRI F., CSERNETICS Á., NyilASI I., VÁGVÖlGYi Cs. (2009) Cloning of the Rhizomucor miehei 3-hydroxy-3-methylglutaryl-coenzyme A reductase gene and its heterologous expression in Mucor circinelloides. Ant. Leeuwenhoek 95 (1): 55-64.

Ma L.-J., Ibrahim A.S., SkORY C., GrabherR M.G., Burger G. ET AL. (2009) Genomic Analysis of the basal lineage fungus Rhizopus oryzae reveals a whole-genome duplication. PLoS Genet. 5 (7): 1-11.

Mackenzie D.A., Wongwathanarat P., Carter A.T., Archer D.B. (2000) Isolation and use of a homologous histone $\mathrm{H} 4$ promoter and a ribosomal DNA region in a transformation vector for the oilproducing fungus Mortierella alpina. Appl. Environ. Microbiol. 66: 4655-4661.

MADYASTHA K.M., SRIVATSAN J. (1987) Novel transformations of progesterone by a Mucor sp. Can. J. Microbiol. 33: 361-365.

MahatTANATAVEe K., KulPRECHA S. (1991) Production of $\beta$-carotene by Rhodotorula sp. Y1621. Microbial Utiliz. Renew. Resources 7: 295-300.

MAIER F.J., SCHÄFER W. (1999) Mutagenesis via insertional - or restriction enzymemediated - integration (REMI) as a tool to tag pathogenicity related genes in plant pathogenic fungi - Minireview. Biol. Chem. 380: 855-864. 
MaloneK S., MeInHARDT F. (2001) Agrobacterium tumefaciens-mediated genetic transformation of the phytopathogenic ascomycete Calonectria morganii. Curr. Genet. 40: 152-155.

MATHEWS-Roth M.M., KRINSKY N.I. (1987) Carotenoids affect development of UV-B induced skin cancer. Photochem. Photobiol. 46(4): 507-509.

MATHIS P., SCHENCK C.C. (1982) The functions of carotenoids in photosynthesis. Carotenoid chemistry and Biochemistry. Britton G., Goodwin T.W. (ed.), Pergamon Press, Oxford, pp. 339-351.

MAYNe S.T., PARKER R.S. (1989) Antioxidant activity of dietary canthaxanthin. Nutr. Cancer 12(3): 225-236.

Mehta B.J., CerdÁ-Olmedo E. (1995) Mutants of carotene production in Blakeslea trispora. Appl. Microbiol. Biotechnol. 42: 836-838.

Mehta B.J., OBRAzTsova I.N., CerdÁ-Olmedo E. (2003) Mutants and intersexual heterokaryons of Blakeslea trispora for production of $\beta$-carotene and lycopene. Appl. Envir. Microbiol. 69 (7): 4043-4048.

Mertens J.A., SKORY C.D., IBRAHIM A.S. (2006) Plasmids for expression of heterologous proteins in Rhizopus oryzae. Arch. Microbiol. 186: 41-50.

MichAILIDES T.J., OGAWA J.M. (1985) A comparative study of growth characteristics and pathogenicity of Mucor piriformis isolates causing decay of peaches and nectarines. Phytopathol. 75: 1008.

Michielse C.B., HooykaAs P.J.J., van den Hondel C.A.M.J.J., RAM A.F.J. (2005) Agrobacterium-mediated transformation as a tool for functional genomics in fungi. Curr. Genet. 48: 1-17.

Michielse C.B., Salim K., Ragas P., Ram A.F.J., Kudla B., Jarky B., Punt P.J., van DEN HONDEL C.A.M.J.J. (2004) Development of a system for integrative and stable transformation of the zygomycete Rhizopus oryzae by Agrobacterium-mediated DNA transfer. Mol. Genet. Genomics 271: 499-510.

Mikosch T.S.P., LAVRIJSSEN B., SONNENBERG A.S.M., VAN GRIENSVEN L.J.L.D. (2001) Transformation of the cultivated mushroom Agaricus bisporus (Lange) using TDNA from Agrobacterium tumefaciens. Curr. Genet. 39: 35-39.

Misawa N., Satomi Y., Kondo K., Yokohama A., Kajiwara S., Saito T., Ohtano T., MIKI W. (1995) Structure and functional analysis of a marine bacterial carotenoid biosynthesis gene cluster and astaxanthin biosynthetic pathway proposed at the gene level. J. Bacteriol. 177 (22): 6575-6584.

Misawa N., SHIMADA H. (1998) Metabolic engineering for the production of carotenoids in non-carotenogenic bacteria and yeasts. J. Biotechnol. 59: 169-181.

Mokady S., Abramovici A., Cogan U. (1989) The safety evaluation of Dunaliella bardawil as a potential food upplement. Food Chem. Toxicol. 27: 221-226.

Monfort A., Cordero L., MAICAS S., Polaina J. (2003) Transformation of Mucor miehei results in plasmid deletion and phenotypic instability. FEMS Microbiol. Lett. 224: 101-106.

Mosqueda-Cano G., Gutierrez-Corona J.F. (1995) Environmental and developmental regulation of carotenogenesis in the dimorphic fungus Mucor rouxii. Curr. Microbiol. 31: 141-145.

Mullins E.D., Chen X., Romaine P., Raina R., Geiser D.M., Kang S. (2001) Agrobacterium-mediated transformation of Fusarium oxysporum: an efficient tool for insertional mutagenesis and gene transfer. Phytopathol. 91: 173-180.

Mullins E.D., KANG S. (2001) Transformation: a tool for studying fungal pathogens of plants - review. Cell. Mol. Life Sci. 58: 2043-2052.

NAGUiB Y.M. (2000) Antioxidant activities of astaxanthin and related carotenoids. $J$. Agric. Food Chem. 48: 1150-1154. 
NAgy Á., VÁgVÖLgYi Cs., BALla É., FeRENCZY L. (1994) Electrophoretic karyotype of Mucor circinelloides. Curr. Genet. 26: 45-48.

Navarro E., Lorca-Pascual J.M., Quiles-Rosillo M.D., Nicolas F.E., Garre V., TORRES-MARTINEZ S., RuIZ-VAZQUEZ R.M. (2001) A negative regulator of lightinducible carotenogenesis in Mucor circinelloides. Mol. Genet. Genomics 266: 463470.

Navarro E., Ruiz-PÉrez V.L., Torres-Martínez S. (2000) Overexpression of the $\operatorname{crg} A$ gene abolishes light requirement for carotenoid biosynthesis in Mucor circinelloides. Eur. J. Biochem. 267: 800-807.

Nicolás F.E., DE Haro J.P., ToRRes-Martínez S., Ruiz-VÁzQuez R.M. (2007) Mutants defective in a Mucor circinelloides dicer-like gene are not compromised in siRNA silencing but display developmental defects. Fungal. Genet. Biol. 44: 504-516.

NicolÁs F.E., NAVARRo E., RuIZ-VÁzQUEZ R.M. (2008) Lycopene over-accumulation by disruption of the negative regulator gene $\operatorname{crgA}$ in Mucor circinelloides. Appl. Microbiol. Biotechnol. 78: 131-137.

Nicolás F.E., ToRres-Martínez S., Ruiz-VÁzQuez R.M. (2003a) Two classes of small antisense RNAs in fungal RNA silencing triggered by non-integrative transgenes. EMBO J. 22 (15): 3983-3991.

NicolÁs F.E., TORRES-MARTíneZ S., RuIZ-VÁZqueZ R.M. (2003b) Transcriptional activation increases RNA silencing efficiency and stability in the fungus Mucor circinelloides. J. Biotechnol. 142: 123-126.

Ninet L., Renaut F. (1979) Carotenoids. Microbial technology. Peppler H.F., Perlman D. (ed.), Academic Press, New York, Vol. I $2^{\text {nd }}$ ed., pp. 529-544.

Nishino H., Murakosh M., Ii T., TaKemura M., Kuchide M., KanaZawa M., Mou X.Y., Wada S., Masuda M., Ohsaka Y., Yogosawa S., Satomi Y., Jinno K. (2002) Carotenoids in cancer prevention. Cancer Metastasis Rev. 21: 257-264.

Nyilasi I., Ács K., PAPP T., VÁGVÖLgYI Cs. (2005) Agrobacterium tumefaciens-mediated transformation of Mucor circinelloides. Folia Microbiol. 50: 415-420.

Nyilasi I., PAPP T., CSERnetics Á., VÁGVÖlgYi Cs. (2008) Agrobacterium tumefaciensmediated transformation of the zygomycete fungus, Backusella lamprospora. J. Basic Microbiol. 48: 59-64.

Obraztsova I.N., Prados N., Holzmann K., Avalos J., Cerdá-Olmedo E. (2004) Genetic damage following introduction of DNA in Phycomyces. Fungal Genet. Biol. 41: 168-180.

OChMAN H., Gerber A.S., HARTL D.L. (1988) Genetic applications of an inverse polymerase chain reaction. Genetics 120: 621-623.

Ogura K., Koyama T. (1998) Enzymatic aspects of isoprenoid chain elongation. Chem. Rev. 98 (4): 1263-1276.

OKAI Y., HigASHI-OKAI K. (1996) Possible immunomodulating activities of carotenoids in in vitro cell culture experiments. Int. J. Immunopharmacol. 18(12): 753-758.

OLSON J.A. (1964) The biosynthesis and metabolism of carotenoids and retinol (Vitamin A) - a review. J. Lipid. Res. 5: 281-299.

Ootaki T., Miyazaki A., Fukui J., Kimura Y., Umemura S., OKaZaki R., Jayaram M. (1991) A high efficient method for introduction of exogenous genes into Phycomyces blakesleeanus. Jpn. J. Genet. 66: 189-195.

ORLOWSKY M. (1991) Mucor dimorphism. Microbiol. Rev. 55: 234-258.

ORLOWSKY M. (1994) Growth, differentiation and sexuality. Growth, differentiation and sexuality, The Mycota. Wessels J.G.H., Meinhardt F. (ed.), Springer Verlag, Vol. I, pp. 143.

ORSET S.C., Young A.J. (1999) Low-temperature-induced synthesis of $\alpha$-carotene in the microalga Dunaliella salina (Chlorophyta). J. Phycol 35: 520-527. 
Ortiz-Alvarado R., GonZales-Hernandez G.A., Torres-GuzMan J.C., GutierreZCORONA J.F. (2006) Transformation of Mucor circinelloides with autoreplicative vectors containing homologous and heterologous $A R S$ elements and the dominant $c b x^{r}$ carboxine-resistant gene. Curr. Microbiol. 52: 178-181.

OUTTRUP H., BOYCE C.O.L. (1990) Microbial proteinases and biotechnology. Microbial enzymes and biotechnology. Fogarty W.M., Kelly C.T. (ed.), Elsevier Applied Science Publ., London, pp. 227-254.

PAIVA S.A.R., RUSSEL R.M. (1999) $\beta$-carotene and other carotenoids as antioxidants. $J$. Nutr.5: 426-433.

PalozzA P. (1998) Prooxidant actions of carotenoids in biological systems. Nutrition Rev. 56: 257-265.

PALOZZA P., KRINSKY N.I. (1992) Astaxanthin and canthaxanthin are potent antioxidants in a membrane model. Arch. Biochem. Biophys. 297(2): 291-295.

Palozza P., Maggiano N., Calviello G., Lanza P., Piccioni E., Ranelletti F.O., BARTOLI G.M. (1998) Canthaxanthin induces apoptosis in human cancer cell lines. Carcinogen. 19 (2): 373-376.

PApP T., Csernetics Á., Nyilasi I., ÁbróK M., VÁGVÖlgYi Cs. (2009a) Genetic transformation of Zygomycetes fungi. Progress in Mycology. Rai M., Kövics Gy. (ed.), Scientific Publishers (India), pp. 75-94.

PAPP T., CSERnetics Á., Nyilasi I., VÁGVÖLGYI Cs., ITURRIAGA E.A. (2011) Integration of a bacterial $\beta$-carotene ketolase gene into the Mucor circinelloides genome by the Agrobacterium tumefaciens-mediated transformation (ATMT) method. Microbial Carotenoids: Methods and Protocols, Methods in Molecular Biology. Barredo J.-L. (ed.) Humana Press, N.Y., USA.

Papp T., NAGy G., Csernetics Á., SzeKeres A., VÁGVÖLgyi Cs. (2009b) Beta-carotene production by Mucoralean fungi. J. Eng. Ann. Fac. Eng. Huned. 7: 173-176.

Papp T., Nyilasi I., Csernetics Á., Galgóczy L., VÁGVÖlgyi Cs. (2008) Molecular studies on Zygomycetes fungi causing opportunistic infections. Rev. Med. Microbiol. 19(2): 39-46.

Papp T., Velayos A., BartóK T., Eslava A.P., VÁGVÖlgyi Cs., ItURriaga E.A. (2006) Heterologous expression of astaxanthin biosynthesis genes in Mucor circinelloides. Appl. Microbiol. Biotechnol. 69(5): 526-531.

PECK R.F., Johnson E.A., KREBS M.P. (2002) Identification of a lycopene $\beta$-cyclase required for bacteriorhodopsin biogenesis in the archaeon Halobacterium salinarium. J. Bacteriol. 184: 2889-2897.

Punt P.J., Dingemanse M.A., Jacobs-Meising B.J.M., Pouwels P.H., van DEN Hondel C.A.M.J.J. (1988) Isolation and characterization of the glyceraldehyde-3-phosphate dehydrogenase gene of Aspergillus nidulans. Gene 69: 49-57.

RAMIREZ J., NunEZ M.L., VALDIVIA R. (2000) Increased astaxanthin production by a Phaffia rhodozyma mutant grown on date juice from Yucca fillifera. J. Ind. Microbiol. Biotechnol. 24: 187-190.

ReVuelta J.L., JAYARAM M. (1986) Transformation of Phycomyces blakesleeanus to G418 resistance by an autonomously replicating plasmid. Proc. Natl. Acad. Sci. USA 83: 7344-7347.

Ribes J.A., VANOVER-SAms C.L., BAKeR D.J. (2000) Zygomycetes in Human Disease. Clin. Microbiol. Rev. 13: 236-301.

RHo H.S., KANG S., LEE Y.H. (2001) Agrobacterium tumefaciens-mediated transformation of the plant pathogenic fungus Magnaporthe grisea. Mol. Cells 12: 407-411.

Rhounim L., Rossignol J.L., FAUGeron G. (1992) Epimutation of repeated genes in Ascobolus immersus. EMBO J. 11: 4451-4457.

RoDRÍGUEZ-AMAYA D.B. (2001) A guide to carotenoid analysis in foods. International Life Sciences Institute Press (ILSI Press), Washington, D.C, USA. 
RODRÍGUEZ-CONCEPCIÓN M., BORONAT A. (2002) Elucidation of the methylerythritol phosphate pathway for isoprenoid biosynthesis in bacteria and plastids. A metabolic milestone achieved through genomics. Plant Phys. 130: 1079-1089.

Rodríguez-SÁiz M., PAZ B., DE LA Fuente J.L., LÓPEZ-Nieto M.J., CABri W., BARRedo J.L. (2004) Blakeslea trispora genes for carotene biosynthesis. Appl. Environ. Microbiol. 70: 5589-5594.

Rodríguez-Villalón A., PÉREZ-Gil J., Rodríguez-ConcePCión M. (2008) Carotenoid accumulation in bacteria with enhanced supply of isoprenoid precursors by upregulation of exogenous or endogenous pathways. J. Biotechnol. 135: 78-84.

ROHMER M. (1999) The discovery of a mevalonate-independent pathway for isoprenoid biosynthesis in bacteria, algae and higher plants. Nat. Prod. Rep. 16: 565-574.

RomANo N., MACINO G. (1992) Quelling: transient inactivation of gene expression in Neurospora crassa by transformation with homologous sequences. Mol. Microbiol. 6: 3343-3353.

RONCERO M.I.G., JEPSEN L.P., STROMAN P., VAN HEESWIJCK R. (1989) Characterization of a leuA gene and an ARS element from Mucor circinelloides. Gene 84: 335-343.

RuIZ-HERRERA J. (1993) Dimorphism in Mucor species. Dimorphic fungi in biology and medicine. van den Bossche H. Odds F.C., Herridge D. (ed.), Plenum Press, New York, pp. 257-265.

Ruiz-Hidalgo M.J., Eslava A.P., Alvarez M.I., Benito E.P. (1999) Heterologous expression of the Phycomyces blakesleeanus phytoene dehydrogenase gene (carB) in Mucor circinelloides. Curr. Microbiol. 39: 259-264.

SAMBROOK J., FRITSCH E.F., MANIATIS T. (1989) Molecular cloning: A laboratory manual. Cold Spring Harbor, New York.

SANDMANN G. (1997) High level expression of carotenogenic genes for enzyme purification and biochemical characterization. Pure Appl. Chem. 69: 2163-2168.

SANDMANN G., MisaWA N. (2002) Fungal carotenoids. Industrial Applications, The Mycota. Osiewacz H.D. (ed.), Springer-Verlag, Berlin, Heidelberg, pp. 247-262.

Santos M.A., Mateos L., Stahmann K.P., ReVuelta J.L. (2005) Insertional mutagenesis in the vitamin B2 producer fungus Ashbya gossypii. Methods in Biotechnology: Microbial Processes and Products. Barredo J.L. (ed.), Humana Press Inc., Totowa, New Jersey, USA, Vol. XVIII, pp. 283-300.

SCHILDE C., WÖSTEMEYER J., BURMESTER A. (2001) Green fluorescent protein as a reporter for gene expression on the Mucoralean fungus Absidia glauca. Arch. Microbiol. 175: $1-7$.

Schimek C., Kleppe K., SAlem A.-R. Voigt K., Burmester A., Wöstemeyer J. (2003) Sexual reactions in Mortierellales are mediated by the trisporic acid system. Mycol. Res. 107: 736-747.

SCHMIDT-DANNERT C. (2000) Engineering novel carotenoids in microorganisms. Curr. Opin. Biotechnol. 11: 255-261.

Shaish A., AVRon M., PicK U., BEN-AmotZ A. (1993) Are active oxygen species involved in induction of $\beta$-carotene in Dunaliella bardawil? Planta 190: 363-368

ShePherd D., Dasek J., SuZAnne M., Carels C. (1976) Production of zeaxanthin. US patent 3.951.743.

Shimada H., Kondo K., Fraser P.D., Miura Y., Saito T., Misawa N. (1998) Increased carotenoid production by the food yeast Candida utilis through metabolic engineering of the isoprenoid pathway. Appl. Environ. Microbiol. 64 (7): 26762680.

Sieiro C., Poza M., De Miguel T., Villa T.G. (2003) Genetic basis of microbial carotenogenesis. Int. Microbiol. 6: 11-16.

Silva F., TORRES-MARTINeS S., GARRÉ V. (2006) Distinc white collar-1 genes control specific light responses in Mucor circinelloides. Mol. Microbiol. 61: 1023-1037. 
SIMPSON K.L. (1983) Relative value of carotenoids as precursors of vitamin A. Proc. Nutr. Soc. 42: 7-17.

Simpson K.L., NaKayama T.O.M., Chichester C.O. (1964) Biosynthesis of yeast carotenoids. J. Bacteriol. 88: 1688-1694.

SKORY C.D. (2002) Homologous recombination and double-strand break repair in the transformation of Rhizopus oryzae. Mol. Genet. Genomics 268: 397-406.

SKORY C.D. (2004) Repair of plasmid DNA used for transformation of Rhizopus oryzae by gene conversion. Curr. Genet. 45: 302-310.

SKORY C.D. (2005) Inhibition of non-homologous end joining and integration of DNA upon transformation of Rhizopus oryzae. Mol. Gen. Genomics 274: 373-383.

STEINBRENNER J., LINDEN H. (2001) Regulation of two carotenoid biosynthesis genes coding for phytoene synthase and carotenoid hydroxylase during stress-induced astaxanthin formation in the green alga Haematococcus pluvialis. Plant. Physiol. 125: 810-817.

STEINBRENNER J., LINDEN H. (2003) Light induction of carotenoid biosynthesis genes in the green alga Haematococcus pluvialis: regulation by photosynthetic redox control. Plant Mol. Biol. 52: 343-356.

STRED’ANSKÁ S., ŠAJBIDOR J. (1992) Oligounsaturated fatty acid production by selected strains of micromycetes. Folia Microbiol. (Praha) 37 (5): 357-359.

Suarez T., Eslava A.P. (1988) Transformation of Phycomyces with a bacterial gene for kanamycin resistance. Mol. Gen. Genet. 212: 120-123.

Sullivan T.D., RoONEY P.J., KleIN B.S. (2002) Agrobacterium tumefaciens integrates transfer DNA into single chromosomal sites of dimorphic fungi and yields homokaryotic progeny from multinucleate yeast. Eukaryot. Cell 1: 895-905.

Sweigard J.A., Carroll A.M., Farrall L., Chumley F.G., Valent B. (1998) Magnaporthe grisea pathogenicity genes obtained through insertional mutagenesis. Mol. Plant-Microbe Interact. 11: 404-412.

SzCZĘSNA-ANTCZAK M., ANTCZAK T., Piotrowicz-WASiaK M., RZYSKa M., BinkowsKa N., BIELECKI S. (2006) Relationships between lipases and lipids in mycelia of two Mucor strains. Enzyme Microbial Tech. 39: 1214-1222.

SzKopiŃSKA A., PŁochochKA D. (2005) Farnesyl diphosphate synthase; regulation of product specificity-review. Acta Biochim. Pol. 52 (1): 45-55.

TAKaya N., Yanai K., Horiuchi H., OHTA A., TAKagi M. (1996) Cloning and characterization of the Rhizopus niveus leul gene and its use for homologous transformation. Biosci. Biotechnol. Biochem. 60: 448-452.

Takeno S., Sakuradani E., Murata S., InOHara-Ochiai M., Kawashima H., AshiKari T., SHIMIZU S. (2004) Establishment of an overall transformation system for an oilproducing filamentous fungus, Mortierella alpina 1S-4. Appl. Microbiol. Biotechnol. 65 (4): 419-425.

Takeno S., Sakuradani E., Tomi A., Inohara-Ochiai M., KaWashima H., Shimizu S. (2005) Transformation of oil-producing fungus, Mortierella alpina 1S-4, using zeocin, and application to arachidonic acid production. J. Biosci. Bioeng. 100 (6): 617-622.

Tuahjono A.E., Hayama Y., Kakizono T., Terada Y., Nishio N., Nagai S. (1994) Hyper-accumulation of astaxanthin in a green alga Haematococcus pluvialis at elevated temperatures. Biotechnol. Lett. 16: 133-138.

Triglia T., Peterson M.G., KemP D.J. (1988) A procedure for in vitro amplification of DNA segments that lie outside the boundaries of known sequences. Nucl. Acid. Res. 16: 8186.

Tsubokura A., Yoneda H., Mizuta H. (1999) Paracoccus carotinifaciens sp. nov., a new aerobic Gram-negative astaxanthin-producing bacterium. Int. J. Syst. Bacteriol. 49: 277-282. 
VÁGVÖlgyi Cs., LUKÁCS Gy., NyIlasi I., PAPP T. (2004) Development of a lovastatin resistance-based transformation system for Rhizomucor miehei. Clin. Microbiol. Infect. 10 (Suppl. 3): 507.

VAINIO H., RAUTALAHTI M. (1998) An international evaluation of the cancer preventive potential of carotenoids. Cancer Epidemiol. Biomarkers Prev. 7: 725-728.

VAN HEESWIJK R., RONCERO M.I.G. (1984) High frequency transformation of Mucor with recombinant plasmid DNA. Carlsberg. Res. Commun. 49: 691-702.

VAN HEESWIJCK R., RONCERO M.I.G., JEPSEN L.P. (1988) Genetic analysis and manipulation of Mucor species by DNA-mediated transformation. Modern methods of plant analysis. Linskens H.F., Jackson J.F. (ed.) Springer-Verlag, Berlin, pp. 207-220.

VAN WeSt P., KAMOUN S., VAN‘T KloOSTER J.W., Govers F. (1999) Internuclear gene silencing in Phytophthora infestans. Mol. Cell. 3: 339-348.

VAZQUEZ M., SANTOS V., PARAJO J.C. (1997) Effect of the carbon source on the carotenoid profiles of Phaffia rhodozyma strains. J. Ind. Microbiol. Biotechnol. 19: 263-268.

VAZQuez M., SANTOS V., PARAJo J.C. (1998) Fed-batch cultures of Phaffia rhodozyma in xylose-containing media made from wood hydrolysates. Food Biotechnol. 12: 4355.

Velayos A. (2000) Carotenogenesis en Mucor circinelloides. PhD Thesis. Universidad de Salamanca. Salamanca, Spain.

Velayos A., Alvarez M.I., Eslava A.P., ItURRIAGa E.A. (1998) Interallelic complementation at the pyrF locus and the homodimeric nature of orotate phosphoribosyltransferase (OPRTase) in Mucor circinelloides. Mol. Gen. Genet. 260: 251-260.

Velayos A., Blasco J.L., Alvarez M.I., Iturriaga E.A., Eslava A.P. (2000a) Bluelight regulation of phytoene dehydrogenase ( $\operatorname{carB})$ gene expression in Mucor circinelloides. Planta 210: 938-946.

Velayos A., Eslava A.P., ItURRiaga E.A. (2000b) A bifunctional enzyme with lycopene cyclase and phytoene synthase activities is encoded by the carRP gene of Mucor circinelloides. Eur. J. Biochem. 267: 1-12.

Velayos A., Fuentes-Vicente M., Aguilar-Elena R., Eslava A.P., Iturriaga E.A. (2004) A novel fungal prenyl diphosphate synthase in the dimorphic zygomycete Mucor circinelloides. Curr. Genet. 45: 371-377.

Velayos A., LóPez-Matas M.A., Ruiz-Hidalgo M.J., Eslava A.P. (1997) Complementation analysis of carotenogenic mutants of Mucor circinelloides. Fungal Genet. Biol. 22: 19-27.

Velayos A., PapP T., Aguilar-Elena R., Fuentes-Vicente M., Eslava A.P., ItURriaga E.A., Alvarez M.I. (2003) Expression of the $\operatorname{carG}$ gene, encoding geranylgeranyl pyrophosphate synthase, is up regulated by blue light in Mucor circinelloides. Curr. Genet. 43 (2): 112-120.

Verdoes J.C., Krubasik P., SANDMANn G., VAN OoYen A.J.J. (1999a) Isolation and functional characterisation of a novel type of carotenoid biosynthetic gene from Xanthophyllomyces dendrorhous. Mol. Gen. Genet. 262: 453-461.

Verdoes J.C., MisAWA N., VAN OOYEN A.J.J. (1999b) Cloning and characterization of the astaxanthin biosynthetic gene encoding phytoene desaturase of Xanthophyllomyces dendrorhous. Biotechnol. Bioeng. 63: 750-755.

Verdoes J.C., SAndmann G., Visser H., Diaz M., van Mossel M., van Ooyen A.J.J. (2003) Metabolic engineering of the carotenoid biosynthetic pathway in the yeast Xanthophyllomyces dendrorhous (Phaffia rhodozyma). Appl. Environ. Microbiol. 69(7): 3728-3738.

Vidhyavathi R., Venkatachalam L., Sarada R., Ravishankar G.A. (2008) Regulation of carotenoid biosynthetic genes expression and carotenoid 
accumulation in the green alga Haematococcus pluvialis under nutrient stress conditions. J. Exp. Bot. 59 (6): 1409-1418.

Visser H., SAndmanN G., Verdoes J.C. (2005) Xanthophylls in Fungi. Metabolic Engineering of the Astaxanthin Biosynthetic Pathway in Xanthophyllomyces dendrorhous. Methods in Biotechnology: Microbial Processes and Products. Barredo J.L. (ed.), Humana Press Inc., Totowa, New Jersey, USA, Vol. XVIII, pp. 257-272.

Visser H., VAN OOYEN A.J.J., Verdoes J.C. (2003) Metabolic engineering of the astaxanthin-biosynthetic pathway of Xanthophyllomyces dendrorhous. FEMS Yeast Res. 4: 221-231.

VitATENE KFT. (2003) Application for the approval of lycopene from Blakeslea trispora, under the EC regulation No 258/97 of the European Parliament.

WADA M., BEPPU T., HORINOUCHI S. (1996) Integrative transformation of the zygomycete Rhizomucor pusillus by homologous recombination. Appl. Microbiol. Biotechnol. 45: 652-657.

Walsh T.J., Groll A., Hiemenz J., Fleming R., Roilides E., Anaissie E. (2004) Infections due to emerging and uncommon medically important fungal pathogens. Clin. Microbiol. Infect. 10(S1): 48-66.

WANG C.-W., OH M.-K., LiaO J.C. (1998) Engineered isoprenoid pathway enhances astaxanthin production in Escherichia coli. Biotechnol. Bioeng. 6 (2): 235-241.

WARD O. (1995) Microbial production of long-chain PUFAs. Inform. 6: 683-688.

WeI D.S., Zhang Y.H., XING L.J., Li M.C. (2010) Agrobacterium rhizogenes-mediated transformation of a high oil-producing filamentous fungus Umbelopsis isabellina. J. Appl. Genet. 51(2): 225-232.

White M.M., James T.Y., O’Donnell K., Cafaro M.J., Tanabe Y., SugiYama J. (2006) Phylogeny of the Zygomycota based on nuclear ribosomal sequence data. Mycologia 98 (6): 872-884.

WolfF A.M., ARnAU J. (2002) Cloning of glyceraldehyde-3-phosphate dehydrogenaseencoding genes in Mucor circinelloides (Syn. racemosus) and use of the gpdl promoter for recombinant protein production. Fung. Gen. Biol. 35: 21-29.

WÖSTEMEYER J., BuRMESTER A., WeIGEl C. (1987) Neomycin resistance as a dominantly selectable marker for transformation of the zygomycete Absidia glauca. Curr. Genet. 12: 625-627.

YAMADA H., ShimizU S., SHINMEN Y., AKimoto K., KAWASHIMA H., JAREONKITMONGKOL S. (1992) Production of dihomogamma-linolenic acid, arachidonic acid, and eicosapentaenoic acid by filamentous fungi. Industrial applications of single cell oils. Champaign I.L. (ed.), American Oil Chemists Society Press (AOCS), USA Illinois, pp. 118-138.

Yamazaki H., Ohnishi Y., Takeuchi K., Mori N., Shiraishi N., SaKata Y., SuZuki H., HORINOUCHI S. (1999) Genetic transformation of a Rhizomucor pusillus mutant defective in asparagine-linked glycosylation: production of a milk-clotting enzyme in a less-glycosylated form. Appl. Microbiol. Biotechnol. 52: 401-409.

YANAi K., HoriUCHI H., TAKAGi M., YANO K. (1990) Preperation of protoplasts of Rhizopus niveus and their transformation with plasmid DNA. Agric. Biol. Chem. 54: 2689-2696.

YANAI K., HoRiUCHI H., TAKAgi M., YANO K. (1991) Transformation of Rhizopus niveus using a bacterial blasticidin $\mathrm{S}$ resistance gene as a dominant selectable marker. Curr. Genet. 19: 221-226.

Yokoyama A., IzUmida H., MiKi W. (1994) Production of astaxanthin and 4ketozeaxanthin by the marine bacterium, Agrobacterium aurantiacum. Biosci. Biotechnol. Biochem. 58: 1842-1844. 
Zaman Z., Roche S., Fielden P., Frost P.G., Niriella D.C., CAYley A.C. (1992) Plasma concentrations of vitamins $\mathrm{A}$ and $\mathrm{E}$ and carotenoids in Alzheimer's disease. Age Ageing. 21 (2): 91-94.

Zhang X., Li M., Wei D., Wang X., Chen X., Xing L. (2007) Disruption of the fatty acid delta6-desaturase gene in the oil-producing fungus Mortierella isabellina by homologous recombination. Curr. Microbiol. 55: 128-134. 


\section{KÖSZÖNETNYILVÁNÍTÁS}

Mindenekelőtt szeretnék köszönetet mondani Prof. Dr. Vágvölgyi Csabának, a Szegedi Tudományegyetem, Természettudományi és Informatikai Kar, Mikrobiológiai Tanszék vezetőjének, hogy a tanszéken munkámat lehetővé tette, figyelemmel kísérte és támogatta.

Hálával tartozom témavezetőmnek, Dr. Papp Tamásnak, áldozatos munkájáért, aki munkámat mindvégig támogatta, megosztotta velem széleskörü elméleti és gyakorlati szaktudását és megadott minden segítséget munkám sikeres elvégzéséhez.

Külön köszönettel tartozom Dr. Nyilasi Ildikónak és Dr. Lukács Gyöngyinek a sok hasznos tanácsért, ötletadó beszélgetésért és a közösen végzett munkáért. Köszönöm minden közvetlen munkatársamnak, Nagy Gábornak, Bencsik Ottónak, Petkovits Tamásnak, Takó Miklósnak, Dr. Galgóczy Lászlónak, Kocsubé Sándornak, Nagy Lászlónak, Krizsán Krisztinának a laborban nyújtott nélkülözhetetlen segítségüket, barátságukat.

Köszönettel tartozom Szvetnik Attilának, hogy lehetővé tette az elektroporálások elvégzését a Bay Zoltán Biotechnológiai Központban, és ezekben segítségemre volt. Köszönöm Dr. Szekeres Andrásnak a HPLC kísérletek, valamint Bebes Attilának a qPCR kísérletek során nyújtott segítségüket.

Köszönetemet fejezem ki Lele Máriának, Deákné Kulcsár Melindának, valamint Farkas Elvirának a munkám során nyújtott technikai segítségért, valamint Dr. Palágyi Andrásnénak, Kreisch Istvánnénak és Szőnyi Jánosnénak, hogy a munkámmal kapcsolatos hivatalos ügyeket intézték. Köszönet illeti továbbá a Mikrobiológiai Tanszék minden munkatársát és dolgozóját.

És végezetül, de nem utolsó sorban hálával és köszönettel tartozom szüleimnek, akik egész életem folyamán önzetlenül, feltétel nélkül támogattak, és szeretetükkel mindvégig biztos hátteret nyújtottak. 


\section{MellékLetek}

\section{1. melléklet. A járomspórás gombáknál alkalmazott transzformációs rendszerek összehasonlítása.}

\begin{tabular}{|c|c|c|c|c|c|c|}
\hline $\begin{array}{l}\text { Transzf. } \\
\text { módszer }\end{array}$ & Faj & Vektor & $\begin{array}{c}\text { Transzf. gyakoriság } \\
\text { (telepek száma) }\end{array}$ & Fennmaradás & Mitótikus stabilitás (megjegyzés) & Publikáció \\
\hline \multirow{14}{*}{$\begin{array}{l}\text { PEG-mediált } \\
\text { protoplaszt/ } \\
\text { szferoplaszt } \\
\text { transzformáció }\end{array}$} & Absidia glauca & cirkuláris & - & extrakromoszómális & alacsony mitótikus stabilitás & $\begin{array}{l}\text { Wöstemeyer és mtsi. } \\
1987\end{array}$ \\
\hline & $\begin{array}{l}\text { Mortierella } \\
\text { alpina }\end{array}$ & cirkuláris & $1-2 / \mu \mathrm{g}$ DNS & integráció & stabil (rDNS) & $\begin{array}{l}\text { Mackenzie és mtsi. } \\
2000\end{array}$ \\
\hline & $\begin{array}{l}\text { Mortierella } \\
\text { isabellina }\end{array}$ & lineáris & $<1 / \mu \mathrm{g}$ DNS & integráció (géndiszrupció) & stabil & Zhang és mtsi. 2007 \\
\hline & \multirow{11}{*}{$\begin{array}{c}\text { Mucor } \\
\text { circinelloides }\end{array}$} & cirkuláris & $\begin{array}{c}19-720 / \mu \mathrm{g} \mathrm{DNS} / 3,2 \times 10^{6} \\
\text { protoplaszt; } 1-38 / 10-50 \mu \mathrm{g} \\
\text { DNS/2x10 protoplaszt, } \\
\text { vektortól függően }\end{array}$ & extrakromoszómális & - $\quad$ (homológ és heterológ gének) & $\begin{array}{l}\text { van Heeswijck és } \\
\text { Roncero } 1984\end{array}$ \\
\hline & & cirkuláris & $200 / \mu \mathrm{g}$ DNS & - & stabil (heterológ gén) & Dickinson és mtsi. 1987 \\
\hline & & cirkuláris & - & extrakromoszómális & - & $\begin{array}{c}\text { van Heeswijck és mtsi. } \\
1988\end{array}$ \\
\hline & & cirkuláris & $2500 / \mu \mathrm{g}$ DNS & extrakromoszómális & - -(ars) & Roncero és mtsi. 1989 \\
\hline & & cirkuláris & $\leq 6000 / \mu \mathrm{g}$ DNS & extrakromoszómális & alacsony mitótikus stabilitás & Anaya és Roncero 1991 \\
\hline & & cirkuláris & $98 / \mu \mathrm{g}$ DNS & $\begin{array}{c}\text { extrakromoszómális és } \\
\text { integratív }\end{array}$ & $\begin{array}{c}\text { alacsony mitótikus stabilitás } \\
\text { stabil }\end{array}$ & Arnau és mtsi. 1991 \\
\hline & & cirkuláris & $\begin{array}{c}600-800 / \mu \mathrm{g} \text { DNS } / 10^{6} \\
\text { protoplaszt }\end{array}$ & extrakromoszómális & alacsony mitótikus stabilitás (ars) & Benito és mtsi. 1992 \\
\hline & & cirkuláris & $\begin{array}{c}83-488 / \mu \mathrm{g} \mathrm{DNS} / 5 \times 10^{5} \\
\text { protoplaszt }\end{array}$ & extrakromoszómális & alacsony mitótikus stabilitás (heterológ gén) & Iturriaga és mtsi. 1992 \\
\hline & & $\begin{array}{l}\text { cirkuláris } \\
\text { és lineáris }\end{array}$ & $\begin{array}{l}590 \text { illetve } 390 / 10 \mu \mathrm{gDNS} / \\
10^{7} \text { protoplaszt }\end{array}$ & $\begin{array}{l}\text { integráció, de a kis mintaszám } \\
\text { miatt nem zárható ki } \\
\text { extrakromoszómális sem }\end{array}$ & - & Arnau és Stroman 1993 \\
\hline & & cirkuláris & - & extrakromoszómális & alacsony mitótikus stabilitás & Benito és mtsi. 1995 \\
\hline & & cirkuláris & - & extrakromoszómális & - & Velayos és mtsi. 1998 \\
\hline
\end{tabular}




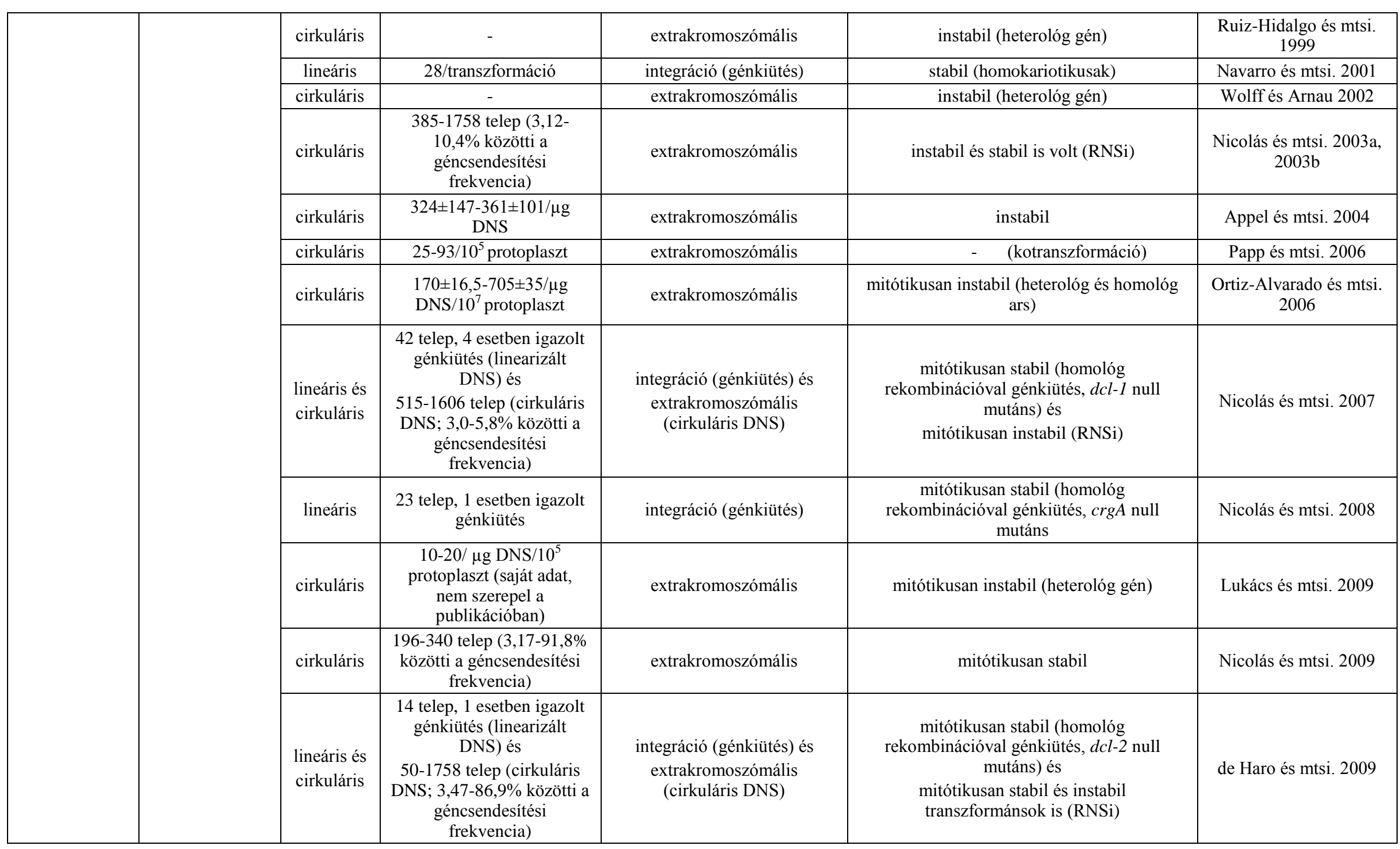




\begin{tabular}{|c|c|c|c|c|c|}
\hline & - & - & - & - & $\begin{array}{l}\text { Navarro és mtsi. } 2000 \\
\text { Velayos és mtsi. } 1997, \\
\text { 2000a, 2000b }\end{array}$ \\
\hline Mucor rouxii & cirkuláris & $1-3 / \mu \mathrm{g}$ DNS & - & - & Appel és mtsi. 2004 \\
\hline $\begin{array}{l}\text { Parasitella } \\
\text { simplex }\end{array}$ & cirkuláris & - & extrakromoszómális & alacsony mitótikus stabilitás & Burmester 1992 \\
\hline \multirow{3}{*}{$\begin{array}{l}\text { Phycomyces } \\
\text { blakesleeanus }\end{array}$} & cirkuláris & $\begin{array}{l}40-60 / \mu \mathrm{g} \text { DNS } / 10^{6} \\
\text { szferoplaszt }\end{array}$ & $\begin{array}{l}\text { extrakromoszómális/többszöri } \\
\text { átoltás után előfordul } \\
\text { integráció (ars) }\end{array}$ & alacsony mitótikus stabilitás? (ars elem) & $\begin{array}{l}\text { Revuelta és Jayaram } \\
1986\end{array}$ \\
\hline & cirkuláris & $\begin{array}{l}\text { 0-3136 között, az átlag 20- } \\
170 / \mu \mathrm{g} \text { DNS/ } 10^{6} \\
\text { szferoplaszt }\end{array}$ & $\begin{array}{l}\text { extrakromoszómális/integráció } \\
\text { is történhetett }\end{array}$ & instabil/stabil & Arnau és mtsi. 1988 \\
\hline & cirkuláris & 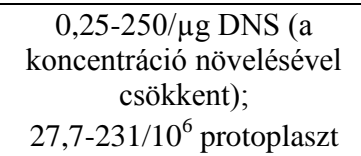 & extrakromoszómális & alacsony mitótikus stabilitás & Suarez és Eslava 1988 \\
\hline \multirow{3}{*}{$\begin{array}{l}\text { Rhizomucor } \\
\text { pusillus }\end{array}$} & $\begin{array}{l}\text { cirkuláris } \\
\text { és lineáris }\end{array}$ & $\begin{array}{c}20 / \mu \mathrm{g} \text { DNS } / 10^{6} \\
\text { protoplaszt } \\
0,1-0,2 / \mu \mathrm{g} \text { DNS } / 10^{6} \\
\text { protoplaszt } \\
\end{array}$ & integráció & - & Wada és mtsi. 1996 \\
\hline & $\begin{array}{l}\text { cirkuláris } \\
\text { és lineáris }\end{array}$ & $\begin{array}{c}5 / \mu \mathrm{g} \mathrm{DNS} / 10^{7} \text { protoplaszt, } \\
\text { minden esetben }\end{array}$ & integráció & & Yamazaki és mtsi. 1999 \\
\hline & cirkuláris & $100 / \mu \mathrm{g}$ DNS & extrakromoszómális & - & Appel és mtsi. 2004 \\
\hline $\begin{array}{l}\text { Rhizomucor } \\
\quad \text { miehei }\end{array}$ & cirkuláris & 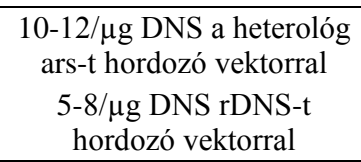 & $\begin{array}{l}\text { extrakromoszómális ars-el; } \\
\text { integráció rDNS-el }\end{array}$ & $\begin{array}{c}\text { instabil }<20 \% \text { a túlélő spórák (heterológ ars } \\
\text { valamint rDNS szekvenciák) }\end{array}$ & Monfort és mtsi. 2003 \\
\hline $\begin{array}{c}\text { Rhizopus } \\
\text { oryzae/Rhizopus } \\
\text { delemar }\end{array}$ & cirkuláris & $0,5-1 / \mu \mathrm{g}$ DNS & integráció & $\begin{array}{l}\text { relatív stabil, ami tovább nőtt az átoltásokkal } \\
\text { (heterológ génexpresszió) }\end{array}$ & Horiuchi és mtsi. 1995 \\
\hline \multirow[t]{2}{*}{ Rhizopus oryzae } & $\begin{array}{l}\text { cirkuláris } \\
\text { és lineáris }\end{array}$ & $\begin{array}{l}0,08-0,1 / \mu \mathrm{g} \text { DNS és } \\
0,15 / \mu \mathrm{g} \text { DNS }\end{array}$ & extrakromoszómális & instabil illetve alacsony mitótikus stabilitás & Michielse és mtsi. 2004 \\
\hline & $\begin{array}{l}\text { lineáris és } \\
\text { cirkuláris }\end{array}$ & $\begin{array}{l}\text { - (13 telep esetében igazolt } \\
\text { homológ rekombináció } \\
\text { általi génkiütés, linearizált }\end{array}$ & $\begin{array}{l}\text { integráció (génkiütés) } \\
\text { extrakromoszómális } \\
\text { (cirkuláris DNS) }\end{array}$ & $\begin{array}{c}\text { mitótikusan stabil (ftrl deléciós mutáns), de } \\
\text { nem homokariotikus } \\
\text { mitótikusan stabil }\end{array}$ & Ibrahim és mtsi. 2010 \\
\hline
\end{tabular}




\begin{tabular}{|c|c|c|c|c|c|c|}
\hline & & & $\begin{array}{c}\text { DNS alkalmazása) } \\
\text { - (50\%-os géncsendesítési } \\
\text { frekvencia) }\end{array}$ & & & \\
\hline & \multirow{4}{*}{ Rhizopus niveus } & cirkuláris & - & $\begin{array}{c}\text { extrakromoszómális és } \\
\text { integráció }\end{array}$ & alacsony mitótikus stabilitás & Yanai és mtsi. 1990 \\
\hline & & $\begin{array}{l}\text { cirkuláris } \\
\text { és lineáris }\end{array}$ & $\begin{array}{c}\text { kettős szelekció után 2- } \\
3 / 25 \mu \mathrm{g} \text { DNS } \\
\end{array}$ & extrakromoszómális & alacsony mitótikus stabilitás & Yanai és mtsi. 1991 \\
\hline & & $\begin{array}{l}\text { cirkuláris } \\
\text { és lineáris }\end{array}$ & $\begin{array}{c}1-20 / \mu \mathrm{g} \text { DNS } \\
\text { lineárissal } 1 / 5 \text {-e a } \\
\text { cirkulárissal meghatározott } \\
\text { számhoz képest }\end{array}$ & $\begin{array}{c}\text { integráció és } \\
\text { extrakromoszómális, a lineáris } \\
\text { fragmenttel nőtt az integráció } \\
\text { esélye }\end{array}$ & $\begin{array}{c}\text { stabil integráció esetén, } \\
\text { extrakromoszómálissal alacsony mitótikus } \\
\text { stabilitás }\end{array}$ & Liou és mtsi. 1992 \\
\hline & & cirkuláris & $0,2-1,9 / \mu \mathrm{g}$ DNS & integráció & $\begin{array}{l}\text { alacsony mitótikus stabilitás, szelektív } \\
\text { körülmények fenntartása szükséges }\end{array}$ & Takaya és mtsi. 1996 \\
\hline \multirow{2}{*}{$\begin{array}{l}\text { PEG-mediált } \\
\text { mikroinjekció }\end{array}$} & \multirow{2}{*}{$\begin{array}{l}\text { Phycomyces } \\
\text { blakesleeanus }\end{array}$} & cirkuláris & $\begin{array}{c}\text { 150/1700 spóra/36 ng } \\
\text { DNS }(8,8 \%)\end{array}$ & extrakromoszómális & stabil & Ootaki és mtsi. 1991 \\
\hline & & cirkuláris & $\begin{array}{c}\leq 1 / \mu \mathrm{g} \mathrm{DNS} / 10^{6} \\
\text { szferoplaszt }\end{array}$ & extrakromoszómális & extrém instabil & $\begin{array}{l}\text { Obraztsova és mtsi. } \\
2004\end{array}$ \\
\hline \multirow{3}{*}{ Elektroporáció } & \multirow{3}{*}{ Absidia glauca } & $\begin{array}{l}\text { cirkuláris } \\
\text { és lineáris }\end{array}$ & - & integráció & $\begin{array}{c}\text { stabil (rag1 elem, repetitív DNS elemek, } \\
\text { morfológiai mutánsok) }\end{array}$ & Burmester és mtsi. 1990 \\
\hline & & cirkuláris & $28-54 / \mu \mathrm{g}$ DNS & extrakromoszómális & voltak stabilak (seg1 elem) & Burmester és mtsi. 1992 \\
\hline & & cirkuláris & - & extrakromoszómális & stabil (rag1, sag1 elemek) & Schilde és mtsi. 2001 \\
\hline \multirow{7}{*}{ Biolisztikus } & Absidia glauca & cirkuláris & $\begin{array}{l}38,4-64,1 / \mu \mathrm{g} \mathrm{DNS} / 10^{7} \\
\text { spóra } \\
\end{array}$ & extrakromoszómális & stabil (rag1 elem) & Bartsch és mtsi. 2002 \\
\hline & \multirow{3}{*}{$\begin{array}{l}\text { Mortierella } \\
\quad \text { alpina }\end{array}$} & cirkuláris & $0,4 / \mu \mathrm{g}$ DNS & integráció & $\begin{array}{c}\text { instabil és } \\
\text { stabil is volt (rDNS) }\end{array}$ & Takeno és mtsi. 2004 \\
\hline & & cirkuláris & $\begin{array}{l}\text { vektortól függően } 0-14 / \mu \mathrm{g} \\
\text { DNS illetve } \\
6,8 / \mu \mathrm{g} \text { DNS } \\
\end{array}$ & integráció & instabil és stabil is volt (rDNS) & Takeno és mtsi. 2005 \\
\hline & & cirkuláris & $40-50 / 4 \times 10^{8}$ spóra & integráció & stabil & Ando és mtsi. 2009a \\
\hline & $\begin{array}{c}\text { Mortierella } \\
\text { isabellina }\end{array}$ & cirkuláris & $>70 / \mu \mathrm{g}$ DNS & - & - & Zhang és mtsi. 2007 \\
\hline & $\begin{array}{c}\text { Mucor } \\
\text { circinelloides }\end{array}$ & cirkuláris & $\begin{array}{c}14 \pm 5-380 \pm 34 / \mu \mathrm{g} \mathrm{DNS} / 10^{7} \\
\text { spóra vagy } 5 \pm 3-55 \pm 10 / \mu \mathrm{g} \\
\mathrm{DNS} / 10^{7} \text { csírázó spóra }\end{array}$ & extrakromoszómális & alacsony mitótikus stabilitás (ars) & $\begin{array}{c}\text { Gonzales-Hernandez és } \\
\text { mtsi. } 1997\end{array}$ \\
\hline & Rhizopus oryzae & $\begin{array}{l}\text { többféle } \\
\text { lineáris } \\
\text { vektor }\end{array}$ & 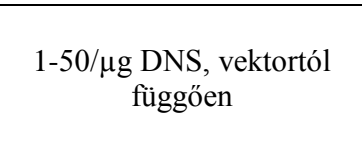 & $\begin{array}{l}\text { extrakromoszómális, ritkán } \\
\text { integráció, de volt olyan } \\
\text { vektor, ahol minden esetben } \\
\text { integráció történt }\end{array}$ & integráció esetén stabil lehet & $\begin{array}{l}\text { Skory } 2002, \\
\text { Skory } 2005\end{array}$ \\
\hline
\end{tabular}




\begin{tabular}{|c|c|c|c|c|c|c|}
\hline & & $\begin{array}{l}\text { cirkuláris } \\
\text { és lineáris } \\
\text { vektor }\end{array}$ & 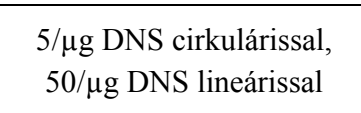 & $\begin{array}{l}\text { extrakromoszómális és } \\
\text { integráció is }\end{array}$ & volt stabil és instabil is & Skory 2004 \\
\hline & & cirkuláris & - & extrakromoszómális & $\begin{array}{c}\text { változó, de föként instabil (heterológ } \\
\text { génexpresszió) }\end{array}$ & Mertens és mtsi. 2006 \\
\hline \multirow{6}{*}{ ATMT } & $\begin{array}{l}\text { Backusella } \\
\text { lamprospora }\end{array}$ & cirkuláris & $\begin{array}{c}\text { alacsony, de az } \\
\text { egybefüggó növekedés } \\
\text { miatt nem volt számolható }\end{array}$ & integráció & instabil & Nyilasi és mtsi. 2008 \\
\hline & $\begin{array}{l}\text { Mortierella } \\
\quad \text { alpina }\end{array}$ & cirkuláris & $\begin{array}{l}\text { körülményektől függően 4- } \\
80 / 10^{7} \text { spóra, (meghaladja } \\
\text { a } 400 / 10^{8} \text { spóra számot) }\end{array}$ & integráció & a telepek nagy része stabil $(60 \%)$ & Ando és mtsi. $2009 b$ \\
\hline & $\begin{array}{c}\text { Mucor } \\
\text { circinelloides }\end{array}$ & cirkuláris & $1-31 / 8 \times 10^{3}$ spóra & integráció & instabil & Nyilasi és mtsi. 2005 \\
\hline & $\begin{array}{l}\text { Rhizomucor } \\
\quad \text { miehei }\end{array}$ & cirkuláris & $50-800 / 10^{7}$ spóra & integráció & instabil & Monfort és mtsi. 2003 \\
\hline & Rhizopus oryzae & cirkuláris & $\begin{array}{l}\text { egybefüggő növekedés } \\
\text { miatt nem volt számolható }\end{array}$ & integráció & nagyon stabil & $\begin{array}{l}\text { Michielse és mtsi. } \\
2004\end{array}$ \\
\hline & $\begin{array}{l}\text { Umbellopsis } \\
\text { isabellina }\end{array}$ & cirkuláris & $5-25 / 10^{6}$ spóra & - & - & Wei és mtsi. 2010 \\
\hline ARMT & $\begin{array}{l}\text { Umbellopsis } \\
\text { isabellina }\end{array}$ & cirkuláris & kb. $10-95 / 10^{6}$ spóra & integráció & stabil & Wei és mtsi. 2010 \\
\hline
\end{tabular}




\section{2. melléklet. M. circinelloides ipi gén kodonhasználata.}

Az ipi arány az adott kodon arányát mutatja az aminosavat kódoló szinonim kodonokhoz viszonyítva, míg az ipi szám az adott kodon összes előfordulását a génben.

\begin{tabular}{|c|c|c|c|c|c|c|c|c|c|}
\hline \multirow{2}{*}{$\begin{array}{c}\text { Kodon } \\
\text { TTT } \\
\end{array}$} & \multicolumn{2}{|c|}{ Aminosav } & \multirow{2}{*}{$\begin{array}{c}\begin{array}{c}\text { ipi } \\
\text { arány }\end{array} \\
33 \%\end{array}$} & \multirow{2}{*}{$\begin{array}{c}\begin{array}{c}\text { ipi } \\
\text { szám }\end{array} \\
4\end{array}$} & \multirow{2}{*}{$\begin{array}{c}\text { Kodon } \\
\text { TAT }\end{array}$} & \multicolumn{2}{|c|}{ Aminosav } & \multirow{2}{*}{$\begin{array}{c}\begin{array}{c}\text { ipi } \\
\text { arány }\end{array} \\
75 \%\end{array}$} & \multirow{2}{*}{$\begin{array}{c}\begin{array}{c}\text { ipi } \\
\text { szám }\end{array} \\
3\end{array}$} \\
\hline & Phe & $\mathrm{F}$ & & & & Tyr & $\mathrm{Y}$ & & \\
\hline TTC & Phe & $\mathrm{F}$ & $66 \%$ & 8 & TAC & Tyr & $\mathrm{Y}$ & $25 \%$ & 1 \\
\hline TTA & Leu & $\mathrm{L}$ & $4 \%$ & 1 & TAA & - & - & $100 \%$ & 1 \\
\hline TTG & Leu & $\mathrm{L}$ & $42 \%$ & 10 & TAG & - & - & $0 \%$ & - \\
\hline CTT & Leu & $\mathrm{L}$ & $17 \%$ & 4 & CAT & His & $\mathrm{H}$ & $71 \%$ & 5 \\
\hline CTC & Leu & $\mathrm{L}$ & $29 \%$ & 7 & CAC & His & $\mathrm{H}$ & $29 \%$ & 2 \\
\hline CTA & Leu & $\mathrm{L}$ & $0 \%$ & - & CAA & Gln & $\mathrm{Q}$ & $62,5 \%$ & 5 \\
\hline CTG & Leu & $\mathrm{L}$ & $8 \%$ & 2 & CAG & Gln & $\mathrm{Q}$ & $37,5 \%$ & 3 \\
\hline ATT & Ile & $\mathrm{I}$ & $42 \%$ & 5 & AAT & Asn & $\mathrm{N}$ & $27 \%$ & 3 \\
\hline ATC & Ile & $\mathrm{I}$ & $58 \%$ & 7 & AAC & Asn & $\mathrm{N}$ & $73 \%$ & 8 \\
\hline ATA & Ile & $\mathrm{I}$ & $0 \%$ & - & AAA & Lys & K & $19 \%$ & 3 \\
\hline ATG & Met & $\mathrm{M}$ & $100 \%$ & 7 & AAG & Lys & $\mathrm{K}$ & $81 \%$ & 13 \\
\hline GTT & Val & $\mathrm{V}$ & $7 \%$ & 1 & GAT & Asp & $\mathrm{D}$ & $45 \%$ & 9 \\
\hline GTC & Val & $\mathrm{V}$ & $57 \%$ & 8 & GAC & Asp & $\mathrm{D}$ & $55 \%$ & 11 \\
\hline GTA & Val & $\mathrm{V}$ & $7 \%$ & 1 & GAA & Glu & $\mathrm{E}$ & $37 \%$ & 7 \\
\hline GTG & Val & $\mathrm{V}$ & $29 \%$ & 4 & GAG & Glu & $\mathrm{E}$ & $63 \%$ & 12 \\
\hline TCT & Ser & $\mathrm{S}$ & $20 \%$ & 2 & TGT & Cys & $\mathrm{C}$ & $0 \%$ & - \\
\hline TCC & Ser & $\mathrm{S}$ & $30 \%$ & 3 & TGC & Cys & $\mathrm{C}$ & $100 \%$ & 5 \\
\hline TCA & Ser & $\mathrm{S}$ & $0 \%$ & - & TGA & - & - & $0 \%$ & - \\
\hline TCG & Ser & $\mathrm{S}$ & $0 \%$ & - & TGG & $\operatorname{Trp}$ & $\mathrm{W}$ & $100 \%$ & 5 \\
\hline CCT & Pro & $\mathrm{P}$ & $30 \%$ & 3 & CGT & Arg & $\mathrm{R}$ & $44 \%$ & 4 \\
\hline $\mathrm{CCC}$ & Pro & $\mathrm{P}$ & $60 \%$ & 6 & CGC & Arg & $\mathrm{R}$ & $44 \%$ & 4 \\
\hline $\mathrm{CCA}$ & Pro & $\mathrm{P}$ & $10 \%$ & 1 & CGA & Arg & $\mathrm{R}$ & $0 \%$ & - \\
\hline CCG & Pro & $\mathrm{P}$ & $0 \%$ & - & CGG & Arg & $\mathrm{R}$ & $0 \%$ & - \\
\hline ACT & Thr & $\mathrm{T}$ & $38 \%$ & 5 & AGT & Ser & $\mathrm{S}$ & $60 \%$ & 3 \\
\hline ACC & Thr & $\mathrm{T}$ & $46 \%$ & 6 & AGC & Ser & $\mathrm{S}$ & $40 \%$ & 2 \\
\hline ACA & Thr & $\mathrm{T}$ & $15 \%$ & 2 & AGA & Arg & $\mathrm{R}$ & $22 \%$ & 1 \\
\hline ACG & Thr & $\mathrm{T}$ & $9 \%$ & - & AGG & Arg & $\mathrm{R}$ & $0 \%$ & - \\
\hline GCT & Ala & A & $42 \%$ & 5 & GGT & Gly & $\mathrm{G}$ & $29 \%$ & 2 \\
\hline GCC & Ala & $\mathrm{A}$ & $50 \%$ & 6 & GGC & Gly & $\mathrm{G}$ & $57 \%$ & 4 \\
\hline GCA & Ala & $\mathrm{A}$ & $8 \%$ & 1 & GGA & Gly & G & $14 \%$ & 1 \\
\hline GCG & Ala & $\mathrm{A}$ & $0 \%$ & - & GGG & Gly & G & 0 & - \\
\hline
\end{tabular}




\section{3. melléklet. A M. circinelloides ipi génje által kódolt IPP izomeráz fehérje}

\section{szekvenciájának összehasonlítása, más, nem közeli rokon fajok IPP izomeráz fehérje szekvenciájával}

M. circinelloides

A. fumigatus

G. zeae

S. pombe

U. maydis

clustal Consensus

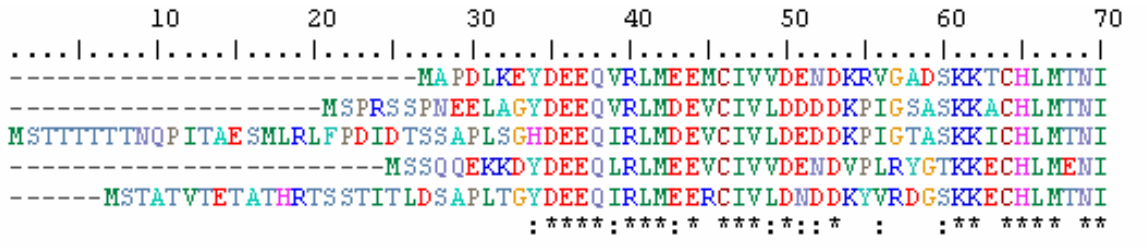

80

100

110

120

130

140 $\ldots|\ldots| \ldots|\ldots| \ldots|\ldots| \ldots|\ldots| \ldots|\ldots| \ldots|\ldots| \ldots|\ldots| \ldots|\ldots| \ldots|\ldots|$

M. circinelloides

A. fumigatus

G. zeae

S. pombe

U. maydis

Clustal Consensus

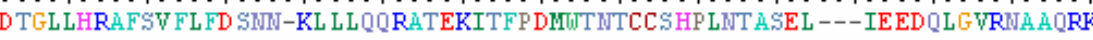

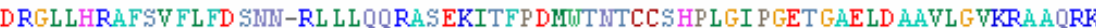
DKGLLHRÄFSV FL FUDKN-EL LLOORÄTEKITFPDMUTNTCC SHPLHI PTET GSTLED SIAGVKRA AORK

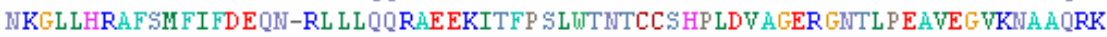
NKGLLHRAF SV FL FD PTTGKL LLQRRAL EKITFP NMTTNTCC SHP LAIKG---ELEE AEQIGVRRA AQRK 150 160

170

180

190

200

210 $\ldots \ldots|\ldots| \ldots|\ldots| \ldots|\ldots| \ldots|\ldots| \ldots|\ldots| \ldots|\ldots| \ldots|\ldots . \ldots| \ldots|\ldots| \ldots|\ldots|$

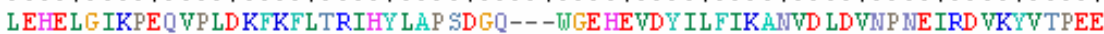

M. circinelloides

A. fomigatus

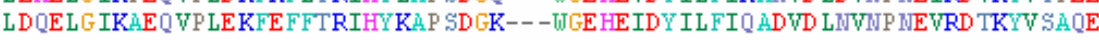
LEHE L G IKKE QVP FE D FHF LTRIHY K L FHE L GIQAKY I PKD KFQFLTRIHY LAP STGA--- -UGE HE IDY I L FK GKVE LD INP NEVQA YKYVTMEE

G. zeae

S. pombe

U. maydis LDHE L G IRÄEQVP LD EFQYLTRIHY LAP NND ANNMUGE HE IDY ILFIT ADVT LKPNL NEVCD TKWV S PEE

clustal Consensus

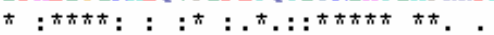

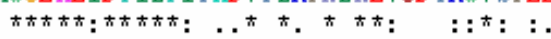

M. circinelloides

220 230 240 250 260 270 $\ldots|\ldots| \ldots|\ldots| \ldots|\ldots| \ldots|\ldots| \ldots|\ldots| \ldots|\ldots| \ldots|\ldots| \ldots \mid$ 法

A. fomigatus

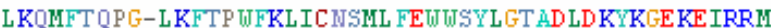

G. zeae

S. pombe LKQQFD D PS - L VFTP WFKL ICNSML FEUWQNLD S G-LD KYLNE QEIRRM-

U. maydis L KEMFSDPQ-YGFTPWFKLICEHFM FKWWQDVDHÅSKF QDTLIHRC

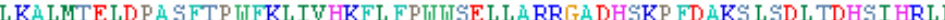

clustal Consensus 
4. melléklet. A M. circinelloides járomspórás gombánál általunk alkalmazott transzformációs rendszerek összehasonlító táblázata.

\begin{tabular}{|c|c|c|c|c|}
\hline \multirow{3}{*}{$\begin{array}{c}\text { Vizsgált } \\
\text { tulajdonság }\end{array}$} & \multicolumn{3}{|c|}{ PEG-mediált protoplaszt transzformáció } & \multirow{3}{*}{ ATMT } \\
\hline & \multirow{2}{*}{ cirkuláris DNS } & \multicolumn{2}{|c|}{ lineáris DNS } & \\
\hline & & génkicserélődés & REMI & \\
\hline Transzformált sejt & protoplaszt & protoplaszt & protoplaszt & spóra/ protoplaszt \\
\hline $\begin{array}{l}\text { Transzformációs } \\
\text { gyakoriság }\end{array}$ & $\begin{array}{c}\text { magas } \\
\text { (15-25 telep/transzformáció, } 10^{5} \\
\text { protoplaszt, } 10-20 \mu \mathrm{g} \\
\text { transzformáló DNS) }\end{array}$ & $\begin{array}{c}\text { alacsony } \\
\left(1-3 \text { telep/transzformáció, } 10^{5}\right. \\
\text { protoplaszt, } 10-20 \mu \mathrm{g} \text { transzformáló } \\
\text { DNS })\end{array}$ & $\begin{array}{c}\text { alacsony } \\
\text { (1-4 telep/transzformáció, } 10^{5} \\
\text { protoplaszt, } 10-20 \mu \mathrm{g} \\
\text { transzformáló DNS) }\end{array}$ & $\begin{array}{c}\text { alacsony/közepes } \\
\text { (1-8 telep//transzformáció, } 10^{6} \\
\text { protoplaszt, ugyanannyi } \\
\text { Agrobacterium sejt) }\end{array}$ \\
\hline Mitótikus stabilitás & stabil & stabil & stabil & instabil \\
\hline $\begin{array}{l}\text { A transzformáló } \\
\text { DNS sorsa }\end{array}$ & autonóm replikálódó & $\begin{array}{l}\text { integráció (kivágódás és } \\
\text { recirkularizáció?) }\end{array}$ & $\begin{array}{l}\text { integráció (kivágódás és } \\
\text { recirkularizáció?) }\end{array}$ & $\begin{array}{l}\text { integráció (kivágódás és } \\
\text { recirkularizáció?) }\end{array}$ \\
\hline DNS átrendeződés & igen & igen & igen & igen \\
\hline $\begin{array}{l}\text { A transzformáló } \\
\text { DNS kópiaszáma }\end{array}$ & $\begin{array}{c}\text { változó } \\
(0,07-7 \text { kópia/genom) } \\
\end{array}$ & $\begin{array}{c}\text { általában magas } \\
(0,03-286 \text { kópia/genom) }\end{array}$ & $\begin{array}{c}\text { általában alacsony } \\
(0,01-46 \text { kópia/genom })\end{array}$ & $\begin{array}{c}\text { extrém alacsony } \\
(0,003-0,3 \text { kópia/genom })\end{array}$ \\
\hline $\begin{array}{c}\text { A bejuttatott gén } \\
\text { expressziója }\end{array}$ & igen & igen & igen & igen \\
\hline Nehézségek & $\begin{array}{l}\text { - kópiaszám ingadozás } \\
\text { - törzsek fenntartása gyakori } \\
\text { átoltást igényel }\end{array}$ & $\begin{array}{c}\text { - nagy mennyiségü lineáris } \\
\text { fragmentum és kiterjedt homológ } \\
\text { szakasz szükséges } \\
\text { - gyakran sikertelen a } \\
\text { transzformáció } \\
\end{array}$ & $\begin{array}{l}\text { - nagy mennyiségü lineáris } \\
\text { fragmentum szükséges } \\
\text { - gyakran sikertelen a } \\
\text { transzformáció }\end{array}$ & $\begin{array}{c}\text { - az együtt-tenyésztési hőmérséklet } \\
\text { és idő optimalizációja szükséges } \\
\text { - gyakran instabil } \\
\text { - baktériumsejtek eliminációja } \\
\text { nehézkes }\end{array}$ \\
\hline
\end{tabular}




\section{5. melléklet. A transzformáns törzseket és jellegzetességeiket összefoglaló táblázat.}

\begin{tabular}{|c|c|c|c|c|}
\hline \multirow{2}{*}{ Transzformáns törzs } & \multicolumn{2}{|l|}{ Genotípus } & \multirow{2}{*}{$\begin{array}{c}\text { A bejuttatott } \\
\text { DNS } \\
\text { fennmaradása }\end{array}$} & \multirow{2}{*}{ Telepszín } \\
\hline & Bejuttatott gén(ek) & \begin{tabular}{|c|}
$\begin{array}{c}\text { Szelekciós } \\
\text { gén }\end{array}$ \\
\end{tabular} & & \\
\hline MS12+pPT50 & gpdlP-crtZ-gpdlT & pyrG & $\begin{array}{l}\text { autonóm } \\
\text { replikálódó }\end{array}$ & sárga \\
\hline MS12+pPT51 & gpdlP-crtW-gpdlT & $\operatorname{leu} A$ & $\begin{array}{l}\text { autonóm } \\
\text { replikálódó }\end{array}$ & narancs \\
\hline MS12+pPT50; pPT51 & $\begin{array}{l}\text { gpdlP-crtZ-gpdlT; } \\
\text { gpdlP-crtW-gpdlT }\end{array}$ & pyrG; leuA & $\begin{array}{c}\text { autonóm } \\
\text { replikálódó }\end{array}$ & narancs \\
\hline MS12+pCA10 & ipi & pyrG & $\begin{array}{c}\text { autonóm } \\
\text { replikálódó }\end{array}$ & sárga \\
\hline MS12+pAVB160 & isoA & leuA & $\begin{array}{c}\text { autonóm } \\
\text { replikálódó }\end{array}$ & sárga \\
\hline MS12+pCA6 & $\operatorname{car} G$ & pyrG & $\begin{array}{l}\text { autonóm } \\
\text { replikálódó }\end{array}$ & sárga \\
\hline $\begin{array}{l}\text { MS12+pCA10; } \\
\text { pAVB160 }\end{array}$ & ipi; isoA & pyrG; leuA & $\begin{array}{c}\text { autonóm } \\
\text { replikálódó }\end{array}$ & sárga \\
\hline $\begin{array}{l}\text { MS12+pCA10; } \\
\text { pAVB161 }\end{array}$ & ipi; carG & pyrG; leuA & $\begin{array}{c}\text { autonóm } \\
\text { replikálódó }\end{array}$ & sárga \\
\hline $\begin{array}{c}\text { MS12+pAVB160; } \\
\text { pCA6 }\end{array}$ & isoA; carG & leuA; pyrG & $\begin{array}{c}\text { autonóm } \\
\text { replikálódó }\end{array}$ & sárga \\
\hline MS12+pPT85 & gpdlP-ipi-gpdlT & leuA & $\begin{array}{l}\text { autonóm } \\
\text { replikálódó }\end{array}$ & sárga \\
\hline MS12+pPT83 & gpdlP-isoA-gpdlT & pyrG & $\begin{array}{l}\text { autonóm } \\
\text { replikálódó }\end{array}$ & sárga \\
\hline MS12+pPT84 & gpdlP-carG- gpd1T & pyrG & $\begin{array}{l}\text { autonóm } \\
\text { replikálódó }\end{array}$ & sárga \\
\hline MS12+pPT85; pPT83 & $\begin{array}{l}\text { gpdlP-ipi-gpdlT; } \\
\text { gpdlP-isoA-gpdlT }\end{array}$ & leuA; pyrG & $\begin{array}{l}\text { autonóm } \\
\text { replikálódó }\end{array}$ & sárga \\
\hline MS12+pPT85; pPT84 & $\begin{array}{c}\text { gpdP-ipi-gpdlT; } \\
\text { gpdlP-carG-gpdlT }\end{array}$ & leuA; pyrG & $\begin{array}{l}\text { autonóm } \\
\text { replikálódó }\end{array}$ & sárga \\
\hline MS12+pPT86; pPT84 & $\begin{array}{l}\text { gpdlP-isoA-gpdlT; } \\
\text { gpdlP-carG- gpdlT }\end{array}$ & leuA; pyrG & $\begin{array}{l}\text { autonóm } \\
\text { replikálódó }\end{array}$ & sárga \\
\hline MS12+pPT82; pPT51 & $\begin{array}{l}\text { gpdlP-ipi-gpdlT, } \\
\text { gpd1P-crtW-gpdlT }\end{array}$ & pyrG; leuA & $\begin{array}{l}\text { autonóm } \\
\text { replikálódó }\end{array}$ & narancs \\
\hline MS12+pPT83; pPT51 & $\begin{array}{l}\text { gpdlP-isoA-gpdlT; } \\
\text { gpdlP-crtW-gpdlT }\end{array}$ & pyrG; leuA & $\begin{array}{l}\text { autonóm } \\
\text { replikálódó }\end{array}$ & narancs \\
\hline MS12+pPT84; pPT51 & $\begin{array}{l}\text { gpdlP-carG- gpdlT; } \\
\text { gpdlP-crtW-gpdlT }\end{array}$ & pyrG; leuA & $\begin{array}{c}\text { autonóm } \\
\text { replikálódó }\end{array}$ & narancs \\
\hline MS12+pPT72 & carRP-crtW & pyrG & $\begin{array}{l}\text { autonóm } \\
\text { replikálódó }\end{array}$ & sárga \\
\hline MS12+pCA81f & $\begin{array}{c}\text { leuA - gpdlP-crtW-gpdlT- } \\
\text { leuA5' szekvencia }\end{array}$ & leuA & $\begin{array}{c}\text { integratív } \\
\text { génkicserélödés }\end{array}$ & $\begin{array}{l}\text { sárga és piros- } \\
\text { narancs }\end{array}$ \\
\hline MS12+pCA91f & $\begin{array}{c}18 \mathrm{~S} r D N S-g p d 1 P \text {-crtW-gpdlT } \\
-28 \mathrm{~S} r D N S \\
\end{array}$ & pyrG & $\begin{array}{c}\text { integratív } \\
\text { génkicserélödés }\end{array}$ & $\begin{array}{c}\text { sárga és piros- } \\
\text { narancs } \\
\end{array}$ \\
\hline MS12+pCA8R & gpdlP-crtW-gpdlT & leuA & $\begin{array}{c}\text { integratív } \\
\text { REMI }\end{array}$ & $\begin{array}{c}\text { sárga és piros- } \\
\text { narancs } \\
\end{array}$ \\
\hline MS12+pPT51R & gpdlP-crtW-gpdlT & leuA & $\begin{array}{c}\text { integratív } \\
\text { REMI }\end{array}$ & $\begin{array}{c}\text { sárga és piros- } \\
\text { narancs }\end{array}$ \\
\hline $\mathrm{MS} 12+\mathrm{pPK} 2 \mathrm{~W}$ & gpdlP-crtW-gpdlT & pyrG & $\begin{array}{l}\text { integratív } \\
\text { ATMT }\end{array}$ & sárga \\
\hline
\end{tabular}

